\title{
GEOLOGICALLY CONSTRAINED ELECTROFACIES CLASSIFICATION OF FLUVIAL DEPOSITS: AN EXAMPLE FROM THE CRETACEOUS MESAVERDE GROUP, UINTA AND PICEANCE BASINS
}

by

\author{
DANIEL B. ALLEN
}

B.S., The University of Texas at Austin, 2010

\author{
A thesis submitted to the \\ Faculty of the Graduate School of the \\ University of Colorado in partial fulfillment \\ of the requirement for the degree of \\ Master of Science \\ Department of Geological Sciences
}

2013 
This thesis entitled:

Geologically constrained electrofacies classification of fluvial deposits: an example from the Cretaceous Mesaverde Group, Uinta and Piceance basins

Written by Daniel B. Allen

has been approved for the Department of Geological Sciences

Matthew J. Pranter

Rex D. Cole

Edmund R. Gustason III

\section{Date}

The final copy of this thesis has been examined by the signatories, and we

Find that both the content and the form meet acceptable presentation standards

Of scholarly work in the above mentioned discipline 


\begin{abstract}
Daniel B. Allen (M.S., Geology [Department of Geological Sciences])
\end{abstract}

Geologically constrained electrofacies classification of fluvial deposits: an example from the Cretaceous Mesaverde Group, Uinta and Piceance basins

Thesis directed by Professor Matthew J. Pranter

Statistical classification methods consisting of the k-nearest neighbor algorithm (k-NN), a probabilistic clustering procedure (PCP), and a novel method which incorporates outcrop-based thickness criteria through the use of well-log-indicator flags are evaluated for their ability to distinguish the fluvial architectural elements of the upper Mesaverde Group of the Piceance and Uinta basins as distinct electrofacies classes.

Study data utilized in the training and testing of the classification methods come from 1626 wireline-log curve depth samples each associated with a known architecturalelement classification as determined from detailed sedimentologic analysis of cores $(\mathrm{N}=9)$. Thickness criteria used in this study are derived from outcrop-based architecturalelement measurements made by previous workers of the upper Mesaverde Group.

Through an approach which integrates select classifier results with thickness criteria, an overall accuracy (number of correctly predicted samples/total testing samples) of $83.6 \%$ was achieved for a simplified four-class architectural-element realization. Architectural elements were predicted with user's accuracies (accuracy of an individual class) of $0.891,0.376,0.735$, and 0.985 for the floodplain, crevasse splay, single-story 
channel body, and multi-story channel body classes, respectively. Without the additional refinement allowed by the incorporation of thickness criteria, the k-NN and PCP classifiers produced similar results, with the k-NN technique consistently outperforming the PCP technique by a slight margin. In both the k-NN and PCP techniques, the combination of wire-line log curves GR and RHOB proved to be the most useful assemblage tested. 


\section{DEDICATION}

This thesis is dedicated to my parents Stephen and Linda Allen. Thank you for working so hard to give me the opportunities that I have had. 


\section{ACKNOWLEDGEMENTS}

I would like to sincerely thank my advisor Dr. Matthew Pranter for his guidance and support throughout my thesis; I am privileged to have worked with you during my time in graduate school. I would also like to acknowledge my thesis committee members Rex Cole and Gus Gustason for their input and assistance with this work. Special thanks also go to Mike Uland of iResevoir in Littleton, Colorado for his willingness to impart knowledge which furthered this research.

I would also like to thank my fellow graduate students in no particular order: Tuba Evsan, Aya Attar, John Mcfadden, Ryan Sharma, Ellen Wilcox, Gabriela Keeton, and Christopher Rybowiak. Your friendship has been a great source of joy and encouragement for me over the last two years.

Funding of this research was provided by the Reservoir Characterization and Modeling research Laboratory (RCML) at the University of Colorado through the sponsors of the Williams Fork Consortium: Anadarko, Chevron, Exxon Mobil, Occidental Petroleum Corporation (Oxy), QEP

Resources, Suncor Energy, WPX Energy, iReservoir, Schlumberger, IHS, and Jason. Additional funding was provided through the AAPG Foundation Grants-in-Aid (Norman H. Foster Memorial Grant) and the SEPM Endowment Grant.

Software utilized in this project was provided by several companies; IHS (Petra), Jason (Facies Classifcation module in Powerlog 3.3), and Eric Geoscience, Inc. (GAMLS). 
Contents

Page

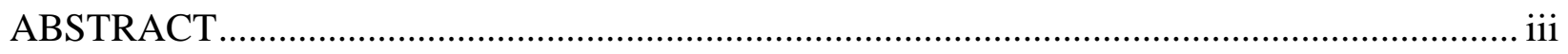

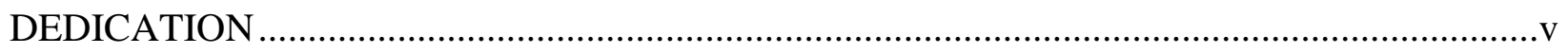

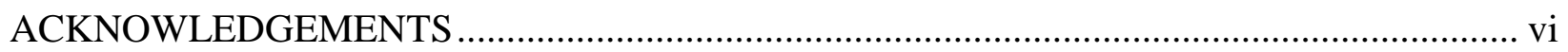

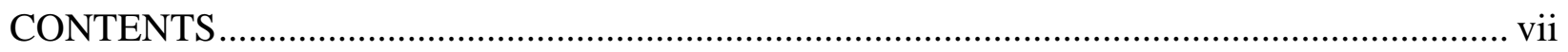

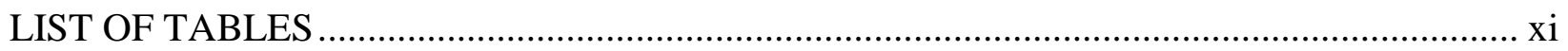

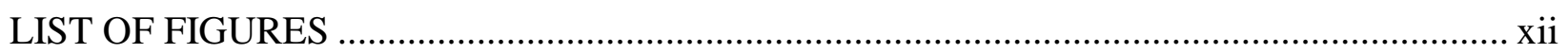

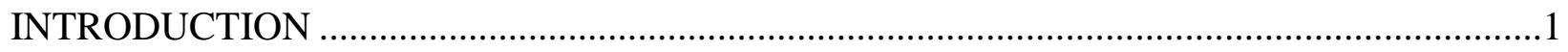

TECTONIC AND STRATIGRAPHIC SETTING .............................................................

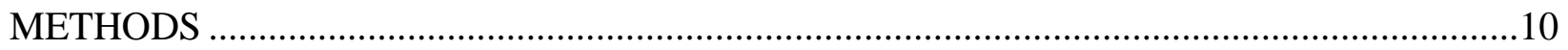

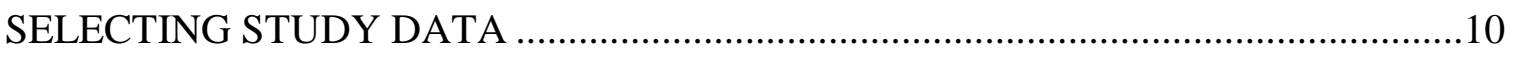

DATA EDITING AND NORMALIZATION .........................................................

CLASSIFYING ARCHITECTURAL ELEMENTS ...............................................12

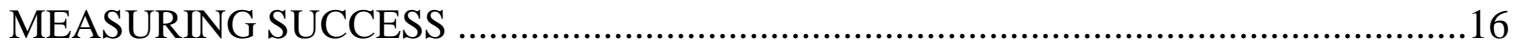

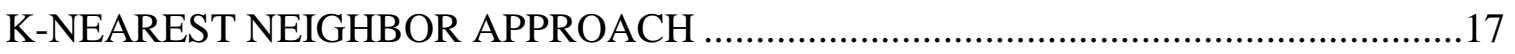

PROBABILISTIC CLUSTERING PROCEDURE ...................................................19

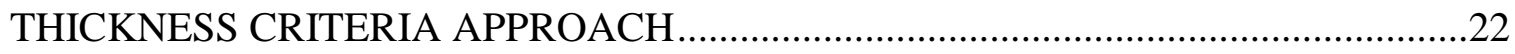


RESULTS

PREDICTION PERFORMANCE OF THE K-NN METHOD .26 PREDICTION PERFORMANCE OF THE PCP CLASSIFIER 31 REFINEMENT OF CLASSIFIER RESULTS WITH THE THICKNESS CRITERIA APPROACH

COMBINING ALIKE ARCHITECTURAL ELEMENTS

COMPARING THE CLASSIFIERS AS TRAINED BY THE DIFFERENT WELL-LOGCURVE ASSEMBLAGES . .45

THE TROUBLESOME SINGLE-STORY CHANNEL BODY ARCHITECTURALELEMENT CLASS .48 INCORPORATION OF THICKNESS CRITERIA AND GEOLOGICALLY CONSTRAINED ELECTROFACIES PREDICTION

CONCLUSIONS .52

REFERENCES .54 
A. Structural boundaries of the Piceance Uinta Basin Province

B. Selecting Training and Testing Samples

C. Distribution of training and testing populations

D. Gamma ray well-log-curve normalization

E. Core description.

F. Lithofacies table

G. Thickness criteria approach

H. Accuracy summary of the prediction results for the five-class architectural-element realization for the $\mathrm{k}-\mathrm{NN}$ classifier.

I. Confusion matrices for the five-class architectural-element realization of the variably trained k-NN classifiers

J. Accuracy summary of the prediction results for the four-class architectural-element realization for the $\mathrm{k}-\mathrm{NN}$ classifier.

K. Confusion matrices for the four-class architectural-element realization of the variably trained k-NN classifiers

L. Accuracy summary of the prediction results for the five-class architectural-element realization for the PCP classifier.

M. Confusion matrices for the five-class architectural-element realization of the variably trained PCP classifiers 
N. Confusion matrices for the four-class architectural-element realization of the variably

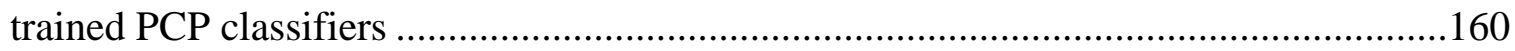

O. Accuracy summary of the prediction results for the four-class architectural-element

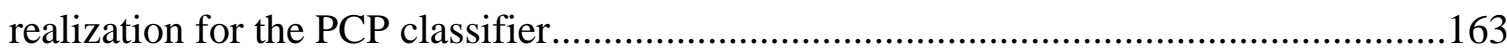

P. Results of including a first derivative transform as a clustering variable in the PCP

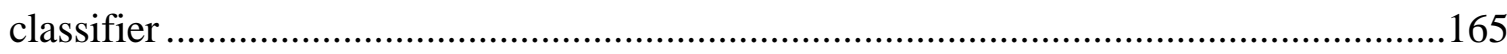

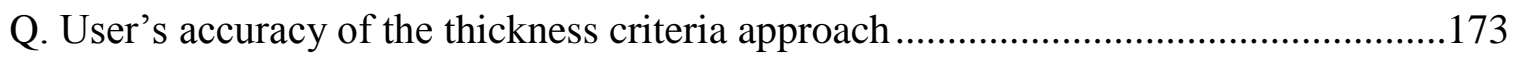

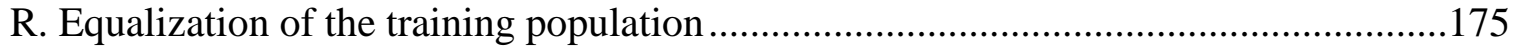

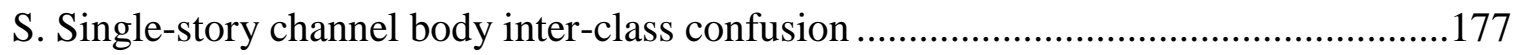




\section{LIST OF TABLES}

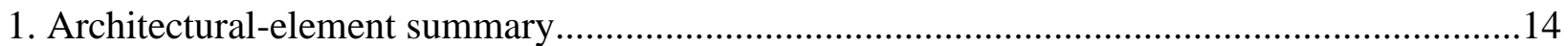

2. Confusion matrix of the combined k-NN and thickness criteria approaches ..........................41 


\section{LIST OF FIGURES}

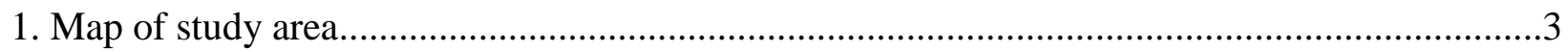

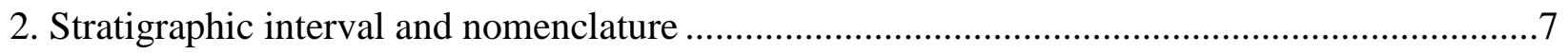

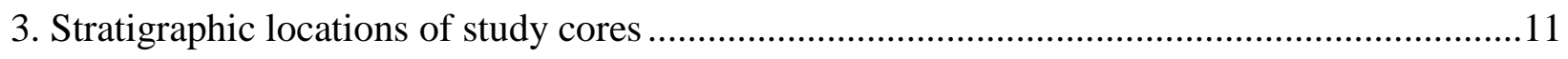

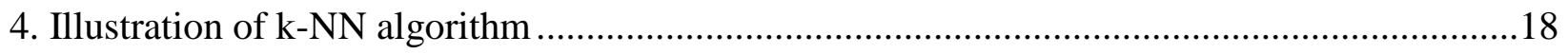

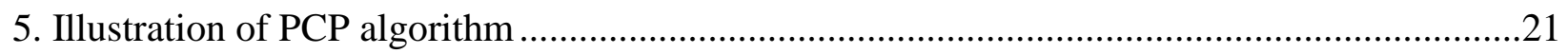

6. Example of architectural elements predicted by well-log-indicator flag approach ..................25

7. User's accuracy of five-class architectural-element realization by k-NN ...........................27

8. User's accuracy of four-class architectural-element realization by k-NN.............................29

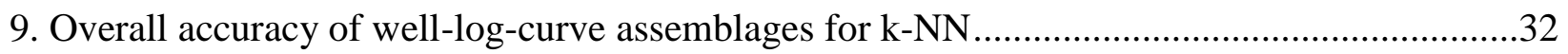

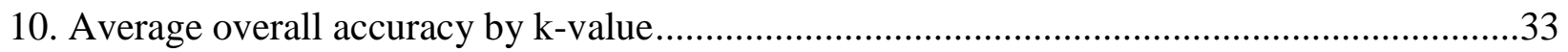

11. User's accuracy of five-class architectural-element realization by PCP .............................35

12. User's accuracy of four-class architectural-element realization by PCP .............................37

13. Overall accuracy of well-log-curve assemblages for PCP ..............................................39

14. Comparison of predicted architectural elements to core-described architectural elements.....43

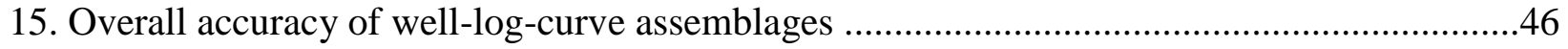

16. Mapping of the predicted architectural elements ........................................................51 
Introduction

The classification of architectural-elements is a vital task in the investigation of fluvial depositional systems. This task is often carried out through the study of core samples or through observations made from outcrop. Numerous such studies (Ellison 2004; Cole and Cumella 2005; German, 2006; Panjaitan 2006; Pranter et al., 2007; Cole, 2008; White et al., 2008; Pranter et al., 2009; Pranter et al, 2011) of the fluvial deposits of the upper Mesaverde Group of the Piceance and Uinta basin province of western Colorado and eastern Utah have recorded detailed sedimentologic analysis, dimensional characteristics (e.g. width, thickness, and width-tothickness ratio) and paleo-current data to describe and classify the different fluvial architecturalelement types common to these deposits. These efforts to classify the fluvial architectural elements and record their distributions has resulted in a better understanding of the fluvial depositional system of the upper Mesaverde Group. Other studies have at least in part if not fully relied on the manual interpretation of fluvial architectural elements in well logs through commonly recognized well-log-curve motifs (Rider, 2002) to assist in the investigation of the sequence stratigraphy of the upper Mesaverde Group (Shaak, 2010) and the static connectivity of the reservoir-quality sandstones that comprise this interval (Hewlett, 2010; Sloan, 2012). Though extensive study has been conducted through the analysis of core and outcrop samples as well as the manual interpretation of well logs, these methods have their constraints. The expenses associated with the retrieval of core samples can be costly and outcrops suitable for study can be geographically limited. Though comparatively more economical, manual interpretation of well logs can be a tedious and subjective task for even the most experienced of well-log analysts. 
As a response to these constraints, this study explores an alternative approach to the classification of fluvial architectural elements through the application of two statistical classification methods: 1) the k-nearest neighbor algorithm (k-NN) and 2) a probabilistic clustering procedure (PCP) in addition to an approach which incorporates outcrop-based, architectural-element thickness criteria to refine the results of the classifiers. These methods are evaluated for their ability to extrapolate the fluvial architectural elements as distinct electrofacies classes from training wells to testing wells through the comparison of wire-line log curve measurements. Data used in the training and testing of the classifiers comes from wire-line log curve depth samples associated with known architectural-element classifications as determined from detailed sedimentologic analysis of cores $(\mathrm{N}=9)$ located throughout the study area (Figure 1).

The discrimination of depositional facies from well-logs dates to the mid 1950's when workers at Shell utilized spontaneous potential (SP) well-log-curve shapes to distinguish depositional facies of the modern Mississippi Delta (Serra, 1989). Studies in the 1970's (Serra and Sulpice, 1975; Rider and Laurier, 1979; Serra and Abbot, 1980) attributed characteristic shapes of additional well-log curves such as gamma ray, bulk density, neutron porosity, and dipmeter logs to depositional facies (Sullivan, et al., 2003). With the ever increasing need for timely and cost effective methods of facies classification, the decades since the 1980's have seen a growth in the application of various statistical approaches to automated electrofacies prediction. The term "electrofacies" was coined by Serra and Abbot (1980) and is defined as, "the set of $\log$ responses which characterizes a bed and permits this to be distinguished from others"- a task typically carried out using simplistic graphical techniques (Doveton and Prensky, 1992). Wolff and Pelissier-Combescure (1982) were early practitioners of the multivariate 


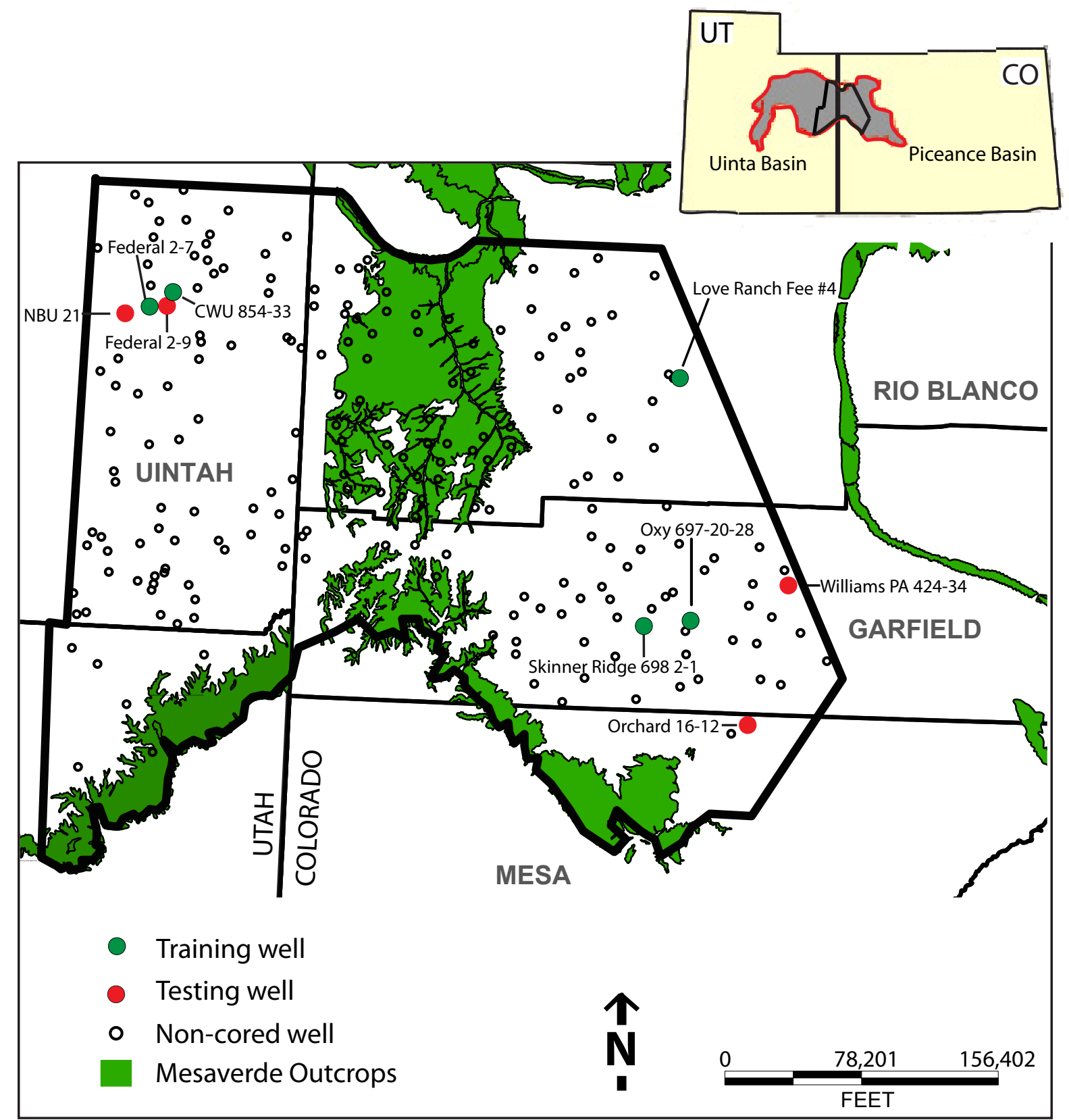

Figure 1: Map of the study area as it is located in the Piceance and Uinta basins of northwestern Colorado and eastern Utah, respectively. Also marked are the locations of the cored wells used in the training and testing of classifier models as well non-cored wells which were selected for demonstrating the batch prediction of electrofacies classes. 
statistical approach to automated facies when they utilized principle component and cluster analysis to estimate the occurrence of lithofacies. The use of multivariate statistics continued with the implementation of discriminant function analysis by Busch, et al. (1987) and Delfiner, et al. (1987) to estimate the occurrence of lithofacies (Dubois, et al., 2006). Perhaps the most popular method of electrofacies classification in recent years (e.g., Kapur et al., 1998; Grotsch and Mercadier, 1999; Saggaf and Nebrija, 2000; Russell et al., 2002) has been the nonmultivariate statistical approach of the artificial neural network which Dubois, et al. (2006) showed to have an advantage in its ability to correctly predict electrofacies classes when compared to other commonly used classification methods. A summary of commonly performed statistical approaches to electrofacies classification can be found in Doveton (1994). As in this study, many of the previously mentioned studies utilize core-defined depositional facies to provide "ground truth" to the predictive capabilities of the classification methods to facilitate acceptance of the results amongst other geoscientists.

This study examines the statistical approaches of the k-nearest neighbor algorithm and a probabilistic clustering procedure. The k-Nearest Neighbor algorithm (k-NN) (Cover and Hart, 1967) is attractively noted as being one of the simplest and most intuitive classification methods (Bremner et al., 2005; Hall et al., 2008). Unlike complex artificial neural network classifiers, this classification method is a simple "look alike" contest where unknown objects are matched according to similar objects with known classes (Dubois, et al., 2006). Though simplistic, in a study comparing the ability of four commonly used classifiers' ability to predict selected lithofacies of the Permian Council Grove Group in the Hugoton and Panoma fields in southwest Kansas and northwest Oklahoma Dubois, et al. (2006) found the k-NN classifier to perform comparatively well. The k-NN classifier has also been applied to distinguishing between ground 
cover classes as captured by satellite imagery and is utilized as a tool in internet search engine functions (McRoberts, et al., 2002; Haapanen, et al., 2004; Beaudoin, et al., 2005; Yeung, et al., 2008). The PCP is a maximum likelihood model-based neural system (but not an artificial neural network) (Eslinger and Boyle, 2011). It is the main clustering engine within the Geologic Analysis via Maximum Likelihood System (GAMLS TM) software. The PCP has been previously employed in past studies in the discrimination of lithofacies of the Barnett Shale (Vallejo, 2010) and has been applied to the estimation of petrophysical properties (Eslinger and Boyle, 2011).

This study addresses 1) the ability of the k-NN and PCP classifiers to distinguish the fluvial architectural elements of the upper Mesaverde Group as distinct electrofacies classes; 2) how the performances of the two classifiers compare to one another; and 3) how outcrop-based, architectural-element thickness criteria can be incorporated into the discrimination of electrofacies classes. The results of this study provide a methodology for making interpretations of the fluvial architectural elements using well logs which is carried out in a cost effective, timely, objective, and reproducible manner.

Tectonic and Stratigraphic Setting

The Laramide-age Uinta and Piceance basins are located in northeastern Utah and northwestern Colorado, respectively (Figure 1). The Uinta Basin is asymmetrical with a westnorthwest trending axis. It is roughly $120 \mathrm{mi}(193 \mathrm{~km})$ in length and nearly $100 \mathrm{mi}(161 \mathrm{~km})$ wide. The basin is bounded by the Uinta Uplift to the north, the Wasatch Plateau to the west, the Rafael and Uncompahgre uplifts to the south, and the Douglas Creek Arch to the west (Spencer, 1995; Stancel, et. al, 2008). The Piceance Basin is asymmetric with a northwest-southeast trending axis. It is $100 \mathrm{mi}(161 \mathrm{~km})$ in length and 40-50 $\mathrm{mi}(64-80 \mathrm{~km})$ wide (Spencer, 1995). The basin is bounded to the northwest by the Uinta Uplift, to the north by the Axial Arch, the 
White River Uplift to the east, the Elk Mountains and Sawatch Uplift to the southeast, the Gunnison Uplift and San Juan Volcanic Field to the south, the Uncompahgre Uplift to the southwest, and is separated from the Uinta Basin by the Douglas Creek Arch to the west (Johnson, 1989) (Appendix A). During the Cretaceous, both the Piceance and Uinta basins were part of the much larger Cretaceous Rocky Mountain Foreland Basin that formed as a result of thrust loading along the Sevier Orogenic Belt, which lies on the western margin of the Uinta Basin. From latest Cretaceous through Eocene time, the foreland basin was separated into several smaller structural and sedimentary basins by rising Laramide uplifts. Subsidence of the Piceance Basin began in late Cretaceous (late Campanian) time and ended during the middle Eocene (Johnson and Finn, 1986; Johnson, 1990; Johnson and Roberts, 2003). In contrast, subsidence of the Uinta Basin did not begin until the Paleoecene and continued into the late Eocene and possibly early Oligocene (Johnson and Finn, 1986).

During the late Cretaceous, the area that is now the Piceance and Uinta basin province was located near the western shoreline of the Western Interior Cretaceous Seaway (Hettinger and Kirschbaum, 2002). Sediments eroded from the Sevier Orogenic Belt in eastern Nevada and western Utah formed a broad piedmont of coalesced alluvial fans that graded eastward into alluvial-plain, coastal-plain, deltaic, and marine settings that comprise the strata of the Mesaverde Group (Cole, 2008; Stancel, et. al, 2008).

This study follows the stratigraphic terminology of Hettinger and Kirschbaum (2002, 2003) for the Mesaverde Group in the southern part of the Piceance and Uinta basins (Figure 2). In the southern part of the Uinta Basin the Mesaverde Group is divided (in ascending order) into the Star Point Sandstone, Blackhawk Formation, Castlegate Sandstone, Sego Sandstone, Neslen Formation, Price River Formation, Farrer Formation, and Tuscher Formation. In the Piceance 


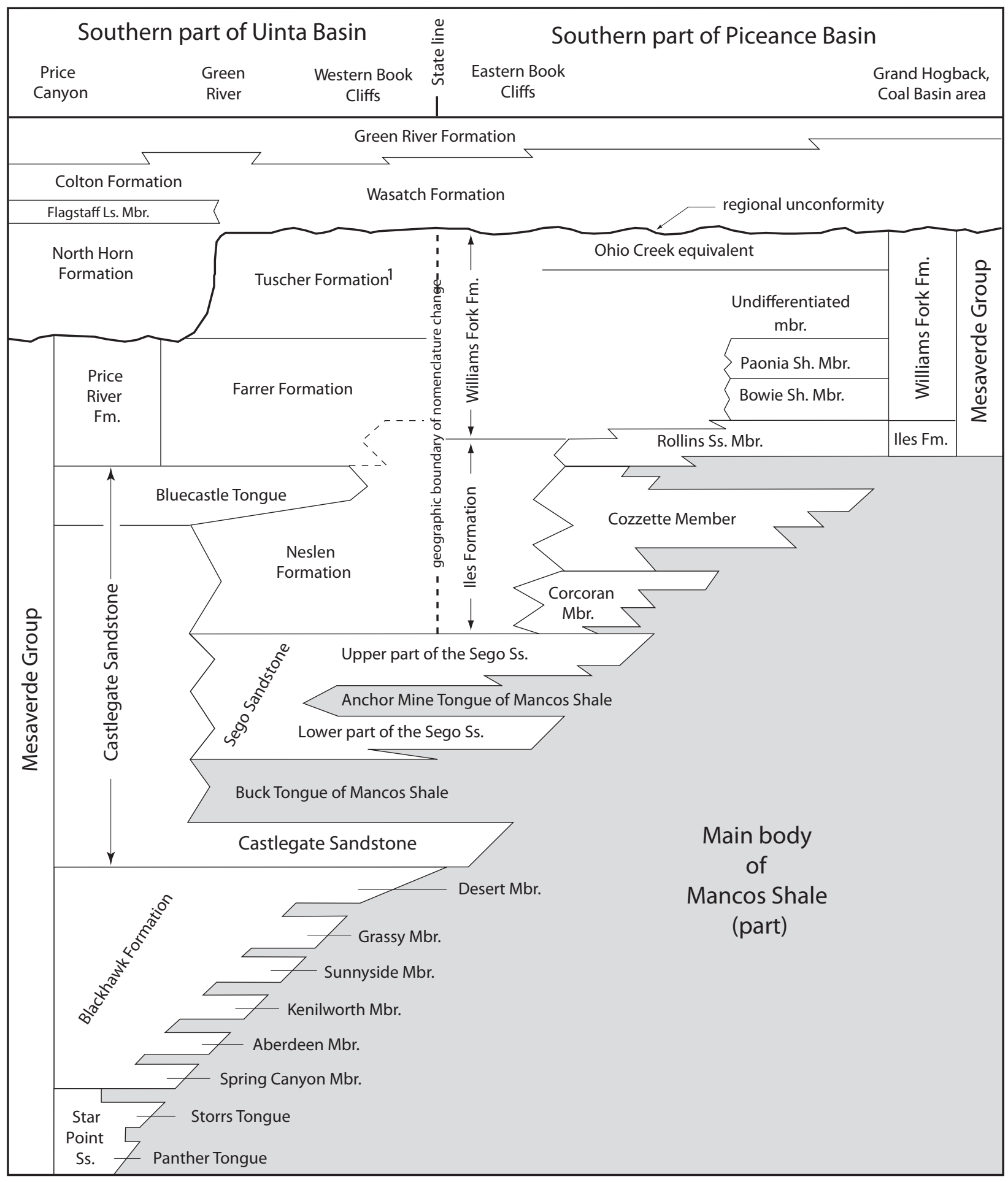

Figure 2: Schematic cross section showing the stratigraphic relationships and nomenclature of the Piceance and Uinta basins. The study interval focuses on the upper part of the Mesaverde Group consisting of the Farrer and Tuscher formations in the Uinta Basin and the Williams Fork Formation in the Piceance Basin (Hettinger and Kirschbaum, 2002). 
Basin the Mesaverde Group is divided into the Castlegate Sandstone, Sego Sandstone, Iles Formation, and Williams Fork Formation (Hettinger and Kirschbaum, 2002). This study focuses on the upper part of the Mesaverde Group in both the Piceance and Uinta basins which includes the similarly deposited Williams Fork Formation and Farrer and Tuscher Formations, respectively (Lawton, 1986; Hettinger and Kirschbaum, 2002).

In the Piceance Basin the Williams Fork Formation overlies the regressive marine Rollins Sandstone Member of the Iles Formation and is disconformably overlain by the Tertiary Wasatch Formation. The Williams Fork Formation is 3600-5155 ft (1097-1571 m) thick along the Grand Hogback and thins westward to about $1200 \mathrm{ft}(366 \mathrm{~m})$ at the Colorado-Utah state line (Hettinger and Kirschbaum, 2002). In the southwestern Piceance Basin, the Williams Fork Formation is informally subdivided into lower (sandstone-poor), and middle/upper (sandstone-rich) intervals based on lithofacies, architectural elements, and net-to-gross ratio (Cole and Cumella, 2005; Pranter 2011, Keeton, 2012). As observed in Coal Canyon, the lower Williams Fork Formation, which also contains the Cameo-Wheeler coal zone at its base, is a relatively low net-to-gross ratio system ( $15 \%$ average net-to-gross ratio) that largely consists of mudrock and isolated channel-form sandstone bodies (channel bars). This lower interval is interpreted to have been deposited by anastomosing to meandering streams in a mostly coastal-plain setting to marginalmarine setting (Lorenz, 1987; Johnson, 1989; Hemborg, 2000; Cole and Cumella, 2003, 2005; Patterson et al., 2003; Pranter et al., 2007). The middle and upper Williams Fork formations, are distinguished by a relatively high net-to-gross ratio system (50-80\% average netto-gross ratio) containing abundant amalgamated sheet-like channel-form sandstone bodies and associated mudrocks that are interpreted to have been deposited in a low sinuosity braided 
alluvial-plain environment (Patterson et al., 2003; Cole and Cumella, 2003, 2005; German, 2006).

In the Uinta Basin, the Farrer and Tuscher formations successively overlie the Neslen Formation, a prograding delta complex that includes tidal and coastal-plain deposits, and are overlain unconformably by the Tertiary Wasatch Formation (Stancel, et. al, 2008). The Farrer Formation extends west from the Utah-Colorado border to Soldier Canyon where it grades into the laterally equivalent Price River Formation. It has been measured at $950 \mathrm{ft}$ (290 m) thick at Tusher Canyon in the southeast part of the basin and thins westward to $131 \mathrm{ft}(40 \mathrm{~m})$ at its western limit. The Farrer Formation consists of fining upwards single-story sandstone bodies, multi-story sandstone bodies, and thick siltstone sequences that are interpreted to have been deposited by a moderate-sinuosity meandering-fluvial system in an upper coastal-plain environment (Lawton, 1986; Hettinger and Kirschbaum, 2002). Net-to-gross ratio begins to increase in the upper portion of the Farrer Formation and the gradational contact with the overlying Tuscher Formation was placed by Lawton $(1983,1986)$ to be where the sandstone content exceeded 50 percent. The Tuscher Formation, which extends westward from the UtahColorado border to near Green River, Utah, ranges from $919 \mathrm{ft}(280 \mathrm{~m})$ in thickness at Tusher Canyon to $358 \mathrm{ft}$ (109 m) at its western limit (Lawton, 1986; White, et. al, 2008). The sandstone dominant Tuscher Formation is characterized by thick amalgamated sheet-like sandbodies with thin siltsone intervals, as well as interspersed thick laterally discontinuous sandstone bodies that feature lateral-accretion surfaces. The Tuscher Formation is interpreted to have been deposited by northeast-flowing meandering and braided-fluvial systems (Lawton, 1986). 
Methodology and Data Set

Selecting Study Data

Data utilized in the training and testing of electrofacies models comes from 1626 samples that are associated with known architectural-element classifications as determined from the detailed sedimentologic analysis of cores $(\mathrm{N}=9$, total footage $1692 \mathrm{ft}$ [515.7 m]). Cores were selected for the study on the basis of 1) accessibility, 2) geographic distribution, 3) stratigraphic distribution and 4) quality (length of core, continuity of cored intervals, few rubblized zones) (Figures 1 and 3). Each sample is also associated with as many as four available measured properties which consist of the wire-line log curves: 1) gamma ray (GR), 2) bulk density (RHOB), 3) deep resistivity (ILD), and 4) neutron porosity (NPHI) (Appendix B). These measured properties were selected based on their common presence in all of the study cores. To evaluate the effective prediction of electrofacies classes in non-cored wells, the study cores were divided into two subsets: a training set (5 cores, 440 samples) and a testing set (4 cores, 1186 samples) (Appendix C).

To demonstrate the applicability of the methods investigated in this study, additional noncored wells $(\mathrm{N}=216)$ were selected throughout the study area in which the most successfully trained classifier would be employed to exhibit the batch prediction of electrofacies classes (Figure 1). These wells were visually inspected and selected on the basis of: 1) geographic coverage, 2) stratigraphic coverage, 3) robustness of wire-line log curve assemblage, 4) data quality (few obvious data spikes, few borehole breakouts, and modern wire-line logs), and 5) non-deviated well paths through the interval of interest. 


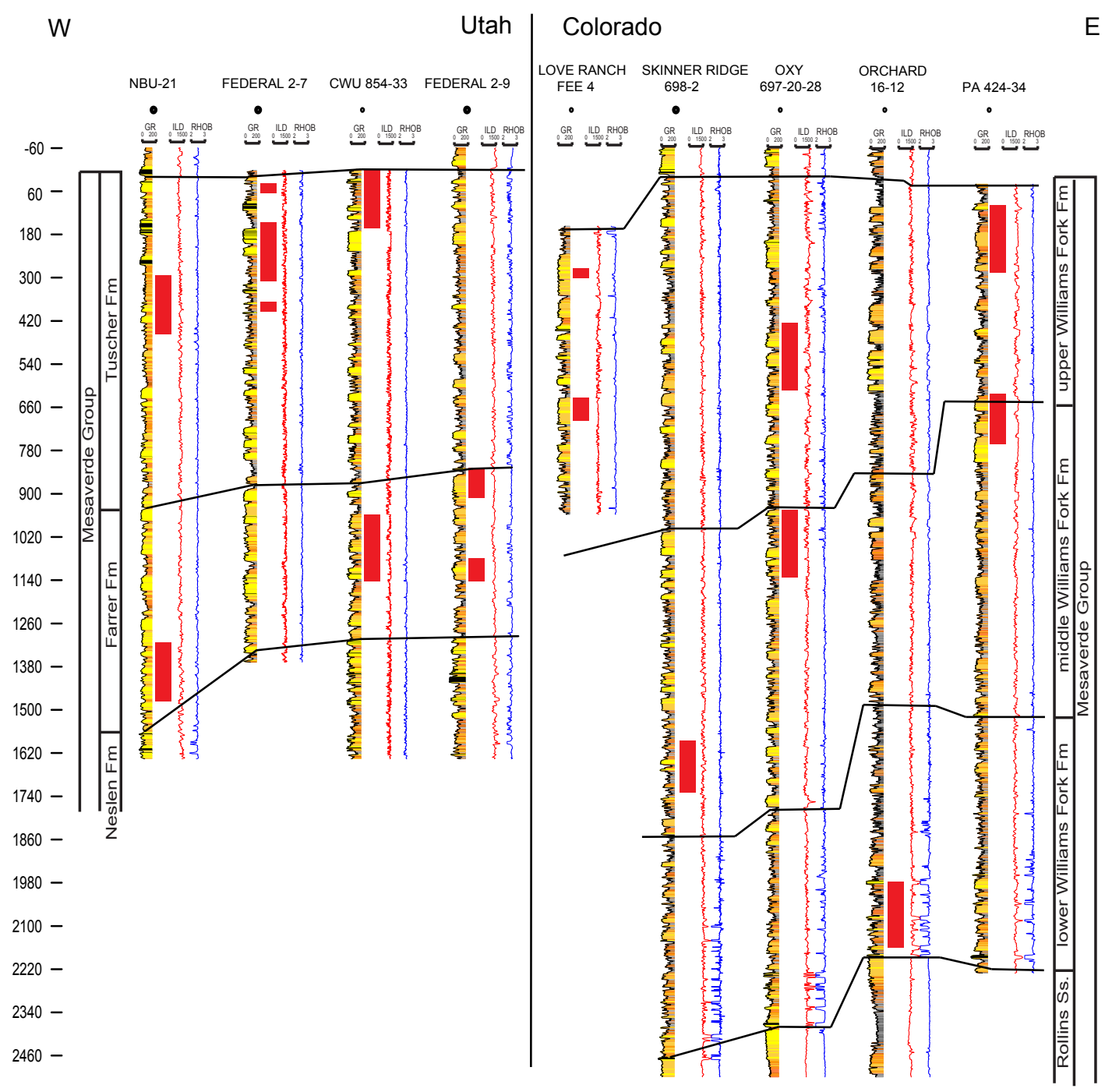

Figure 3: Locations of cored intervals (red bars) in cored wells. See Figure 1 for well locations. Wells are spaced equally apart. Thickness on left is in feet. 
Data Editing and Normalization

Prior to the creation and testing of the training models, several pre-processing subtasks were performed on the wireline data to help ensure reliable electrofacies class assignments: 1) Core-to-log depth shift corrections were made to all well-log curves; 2) Well-log curves were visually inspected to remove obvious data errors or spikes; 3) Where necessary, logs were resampled to a common increment of $0.50 \mathrm{ft}(0.15 \mathrm{~m}) ; 4)$ and, GR curves were normalized using 2-point histogram shifting (Appendix D).

Classifying Architectural Elements

Detailed sedimentologic descriptions (lithology, grain size, texture, sedimentary structures, and contacts) of the study cores were used to determine architectural elements in order to investigate their potential to be grouped into distinct electrofacies classes (Appendix E). To capture the detail necessary for architectural element description, a relatively fine-scale description of lithofacies is required (Miall, 2010). Eleven lithofacies were described in the study cores on a 0.39 in $(1 \mathrm{~cm})$ basis and include: 1) highly fissile mudstone $\left.\left(\mathrm{MF}_{\mathrm{F}}\right), 2\right)$ laminated to mottled mudstone (ML), 3) carbonaceous mudstone (Mc), 4) convoluted sandy siltstone (STsc), 5) wavy laminated sandy siltstone (STwR), 6) argillaceous siltstone (STAM), 7) convoluted silty sandstone (SSTC), 8) ripple laminated sandstone (SR), 9) low-to-high angle crossbedded sandstone $\left.\left(\mathrm{S}_{\mathrm{L}}\right), 10\right)$ convoluted sandstone $\left.\left(\mathrm{SC}_{\mathrm{C}}\right), 11\right)$ structureless/cryptically bioturbated sandstone (Ss) (Appendix F). These lithofacies are similar to those described by past workers of the fluvial deposits of the Mesaverde Group (Cole and Cumella, 2003; Sloan 2012; Harper 2011; Keeton, 2012) and are similar to lithofacies that are universally recognized in fluvial deposits due to the common physical processes that control deposition of clastic fluvial lithofacies (Miall 1978; Miall, 2010). Architectural elements were classified through recognition of distinctive 
assemblages of these lithofacies in addition to the nature of lower and upper bounding surfaces, internal geometry, and scale (thickness) (Miall, 1985). Based on these characteristics as observed in the study cores and by comparing them to observations made in outcrop in past studies of the fluvial deposits of the Mesaverde Group, the following architectural elements were interpreted: 1) floodplain 2) crevasse splays, 3) single-story channel bodies, 4) multi-story channel bodies, 5) amalgamated channel bodies (Cole and Cumella, 2005; Pranter et al., 2009, 2011) (Table 1).

Floodplain deposits represent the laterally continuous medium surrounding ancient fluvial channels and meander belts and are dominated by the highly fissile mudstone, mottled mudstone, and carbonaceous mudstone lithofacies (Bridge, 2006). Abundant carbonaceous root traces sometimes associated with Fe-oxide mottling were commonly observed in floodplain deposits throughout the study cores suggesting humid climatic conditions with flashy, seasonal flooding, and a fluctuating water table (Rettalack, 2001; Flaig, et al., 2011). Pedogenic features such as small calcite nodules do occur within the floodplain facies assemblage but are very rare suggesting little time for soil development in a rapidly aggrading floodplain setting (Smith and Rodgers, 1999). Crevasse splays develop during high runoff events when the channel bank is breached and sediment spreads out to be deposited onto the floodplain area (Bridge and Tye, 2000; Miall, 2010). Crevasse splays tend to feature a coarsening-upward grain-size trend that typically grades from basal mud-rich floodplain lithofacies into wavy to convolute sandysiltstones and up into very-fine to fine grained ripple laminated sandstones. These deposits are often times capped by a sharp contact with overlying floodplain lithofacies and commonly feature a high amount of bioturbation in the form of rooting and probable insect burrowing. Crevasse splays of the Mesaverde Group have been observed in outcrop at Coal Canyon, 


\begin{tabular}{|c|c|c|c|}
\hline $\begin{array}{l}\text { Architectural } \\
\text { Element Class }\end{array}$ & $\begin{array}{c}\text { Principle } \\
\text { Facies Assemblage }\end{array}$ & Description & Interpretation \\
\hline $\begin{array}{l}\text { Floodplain } \\
\text { (FP) }\end{array}$ & $\begin{array}{l}\text { MF, ML, MC, } \\
\text { STAM }\end{array}$ & $\begin{array}{l}\text { Mud-dominated facies assebmlage that typically } \\
\text { features high degrees of bioturbation in the form of } \\
\text { carbonaceous root traces which are commonly } \\
\text { Fe-stained }\end{array}$ & Floodplain \\
\hline $\begin{array}{l}\text { Crevasse } \\
\text { splay } \\
\text { (CS) }\end{array}$ & $\begin{array}{l}\text { STsc, STwr, } \\
\text { SSTC, SR }\end{array}$ & $\begin{array}{l}\text { Typically a coarsening upwards facies sequence with } \\
\text { a gradational basal contact and a sharp overlying } \\
\text { contact. Bioturbation in the form of rooting and } \\
\text { insect burrowing is common }\end{array}$ & Crevasse Splay \\
\hline $\begin{array}{l}\text { Single-story } \\
\text { channel body } \\
\quad(\mathrm{SS})\end{array}$ & $\mathrm{SL}, \mathrm{Sc}, \mathrm{Ss}, \mathrm{SR}$ & $\begin{array}{l}\text { Singular, fine-to-medium grained sand dominated } \\
\text { fining upwards sequence with sharp basal contact } \\
\text { often featuring mud clasts }\end{array}$ & $\begin{array}{l}\text { Isolated point-bar deposit } \\
\text { in high-sinuosity fluvial } \\
\text { system }\end{array}$ \\
\hline $\begin{array}{l}\text { Multi-story } \\
\text { channel body } \\
\text { (MS) }\end{array}$ & $\mathrm{SL}, \mathrm{SC}, \mathrm{Ss}, \mathrm{SR}$ & $\begin{array}{l}\text { Consists of multiple stacked individual channel } \\
\text { bodies made recognizable by the presence of } \\
\text { between two to five internal scour surfaces }\end{array}$ & $\begin{array}{l}\text { Stacked individual channels } \\
\text { in a robust sinuous channel } \\
\text { fluvial system }\end{array}$ \\
\hline $\begin{array}{l}\text { Amalgamated } \\
\text { channel body } \\
\text { (AM) }\end{array}$ & $\mathrm{SL}_{\mathrm{L}}, \mathrm{SC}, \mathrm{Ss}, \mathrm{SR}$ & $\begin{array}{l}\text { A complex conisting of stacked multi-story and } \\
\text { single-story channel bodies typically much larger } \\
\text { in scale than a single multi-story channel body }\end{array}$ & $\begin{array}{l}\text { Fluvial channel deposits } \\
\text { in a low-to-medium sinuosity } \\
\text { braided fluvial system }\end{array}$ \\
\hline
\end{tabular}

Table 1: Summary of the fluvial architectural elements that comprise the Mesaverde Group for the studied cores of the Piceance Basin, CO and the Uinta Basin, UT. 
Colorado to have an average thickness of $2.8 \mathrm{ft}(0.85 \mathrm{~m})$ (Cole and Cumella, 2005). Single-story channel bodies typically represent isolated point-bar deposits which are common in highsinuosity rivers (Ellison, 2004; Cole and Cumella, 2005; Pranter et al., 2007, 2009; Pranter and Sommer 2011; Miall, 2010). These deposits commonly fine upwards and consist of fine-tomedium grained cross-bedded to ripple-laminated sandstone lithofacies with mudchip lags at the base sourced by nearby cutbank erosion. As measured in Mesaverde Group outcrops at Coal Canyon, Colorado, single-story channel bodies average $8.8 \mathrm{ft}(2.7 \mathrm{~m})$ in thickness (Cole and Cumella, 2005). Multi-story channel bodies consist of fine-to-medium grained cross bedded to ripple laminated sandstone lithofacies both of which have the potential to be convoluted or bioturbated. These deposits are characterized by stacked individual channels that are made recognizable by the presence of typically around two to five internal scours which may have a mudchip lag present at their base. This complex internal architecture suggests that these channel bodies, which are observed in outcrop at Coal Canyon, Colorado to average $13.8 \mathrm{ft}(4.2 \mathrm{~m})$ in thickness, were deposited by dynamic fluvial channels in a robust sinuous channel system with significant meander belts (Cole and Cumella, 2005). Amalgamated channel bodies are comprised of stacked assemblages of single-story and multi-story channel bodies. In Mesaverde Group outcrops at Plateau Creek Canyon, Colorado they have been observed to be thicker (average thickness $26 \mathrm{ft}[7.9 \mathrm{~m}]$ ) and more laterally extensive (average width of $870 \mathrm{ft}$ [265 m]) than multi-story channel bodies and are interpreted to have been deposited by a low-to-medium sinuosity braided river system in an alluvial plain setting (Lorenz and Nandon, 2002; Patterson, et al., 2003; German, 2006). 
Measuring Success

A means of judging the trained classifiers' ability to correctly predict electrofacies classes in test wells was needed in order to evaluate and compare classifier performances. A commonly utilized visualization tool, typically used in evaluating supervised learning procedures in the field of artificial intelligence, known as a confusion matrix was selected for this purpose (Ting, 2011). A confusion matrix displays information about the actual and predicted classifications present in a classification system, where each column represents instances of the predicted class and each row represents instances of the actual class (Kohavi and Provost, 1998; Ting, 2011). Data organized in this manner not only displays correctly predicted classes, but also allows for characterization of erroneous inter-class predictions (Foody, 2002).

To quantitatively compare performances between variably trained classifier outcomes, four metrics of success were derived from the content of the confusion matrix: overall accuracy, user's accuracy, predicted volume, and average deviation. Overall accuracy is the simplest and one of the most common accuracy measurements used in confusion matrix analysis (Congalton, 1991). It is calculated by dividing the number of correctly predicted classes (the sum of the major diagonal in the confusion matrix) by the total number of predicted classes. To measure the accuracy of individual class predictions, a similar calculation to overall accuracy is derived from the confusion matrix whereby the number of correctly predicted instances of a particular class is divided by the total number of actual samples that exist for that class. This success metric is known as user's accuracy and is commonly employed in conjunction with overall accuracy when an emphasis is placed on the accuracy of individual class predictions as is the case in this study (Janssen and van der Wel, 1994; Foody, 2002). In addition to measures of accuracy, it is also desirable that the number of predicted samples of a particular class is similar to the number of 
actual samples for that class so that the model accurately represents the actual volumetric distribution of facies (Dubois, et al. 2006). To evaluate the volumetric distributions of individual classes, the total number of predicted samples for a particular class is divided by the number of actual samples for that class. This ratio is multiplied by 100 to give a measure in terms of percentage of the correctness of the volumetric distribution for individual classes termed in this study as "predicted volume". To evaluate correctness of the volumetric distribution of facies for the model as a whole, an average is taken of the absolute differences of the predicted volumes of each individual class from the ideal percentage (100\%). This measure of central tendency is known as the average deviation.

\section{K-Nearest Neighbor Approach}

In the k-NN algorithm, the training phase consists simply of assigning and storing class labels to training samples which are vectors in n-dimensional space. In the classification phase, an unclassified sample (a test sample or query point) is plotted amongst the training data in ndimensional space and is compared to a user-defined constant number $(\mathrm{k})$ of the most similar training samples (nearest neighbors). The test sample is then classified according to the most frequently occurring class out of these k number of nearest training samples (majority rules) (Cover and Hart, 1967; Dubois, et al. 2006) (Figure 4).

Training samples $(\mathrm{N}=440)$ with known architectural-element classifications were selected at random throughout the four training cores where data quality was deemed satisfactory (high quality of associated wireline data, reliable core-to-log depth shift correction, and confidently chosen architectural-element classifications). The n-dimensional space that the training samples are plotted in corresponds to the number of different well-log curves that are utilized, with each sampling point being associated the well-log values at its respective depth. To investigate the 


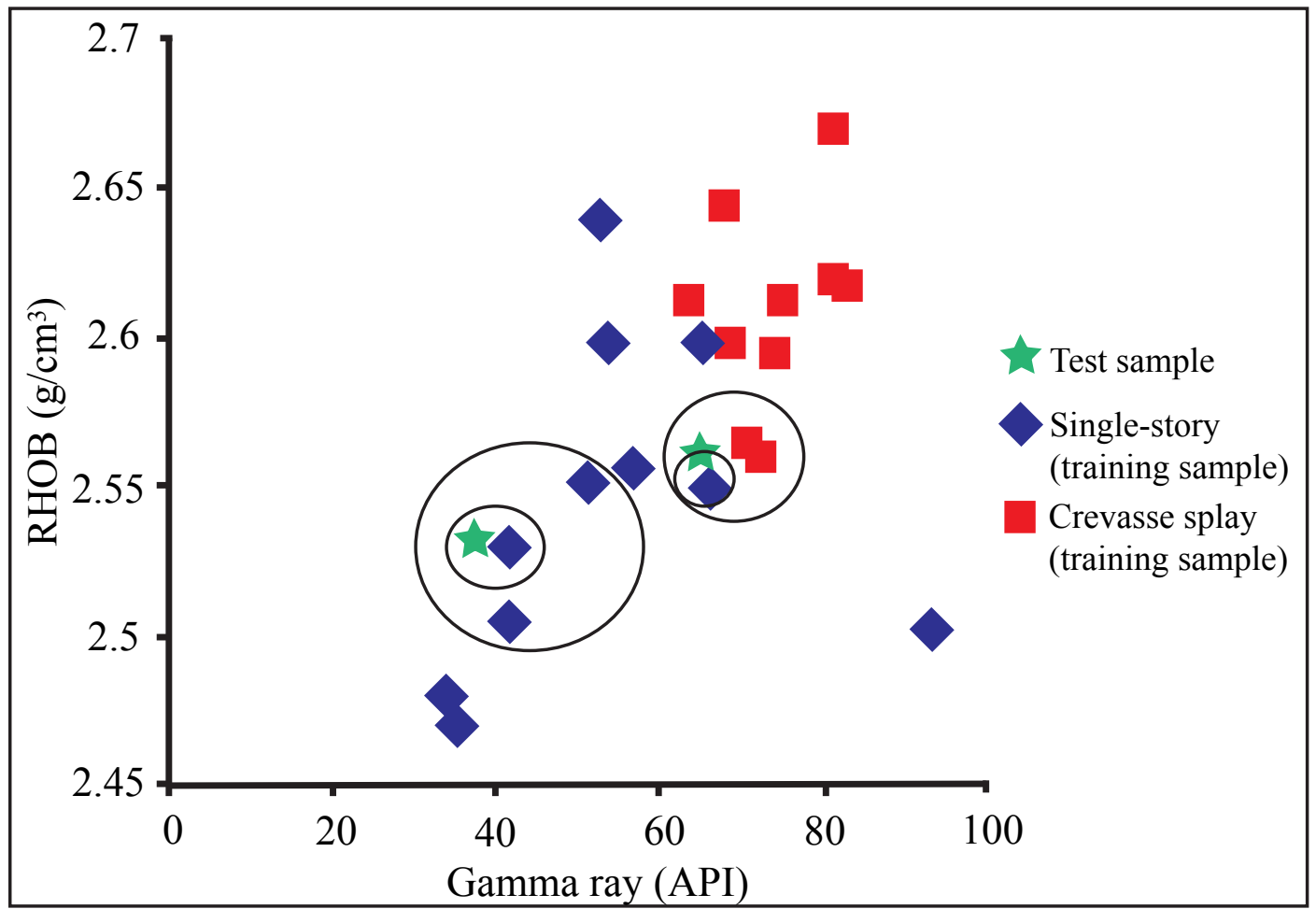

Figure 4: An illustration of the workings of the k-NN algorithm. Test samples (green stars) are plotted amongst 20 randomly selected training samples in a bulk density versus gamma ray crossplot. If the first nearest neighbor $(\mathrm{k}=1)$ is chosen to determine the class of the test sample, as demonstrated by the smaller circles, then both samples are classified as single-story channel bodies. However, if $\mathrm{k}$ is increased to 3, the test sample on the left would remain classified as a single-story channel body whereas the test sample on the right would be classified as a crevasse splay. This demonstrates the potential for confusion at class boundaries. 
effectiveness of the well-log curves chosen for this study (GR, RHOB, ILD, NPHI) in distinguishing between architectural-element classes, the performance of the classifier as trained by seven different well-log-curve assemblages was evaluated. These seven well-log-curve assemblages consist of: 1) GR, RHOB 2) GR, ILD 3) GR, NPHI 4) GR, RHOB, ILD, 5) GR, RHOB, NPHI 6) GR, NPHI, ILD and 7) GR, RHOB, ILD, NPHI. The GR log curve was left static in these assemblages because it is present in all of the selected non-cored study wells.

Determining the number of nearest neighbors (k) to examine when classifying the test sample can be a delicate choice. If the value of $\mathrm{k}$ is too small, there is the potential for outlying sampling points to have a greater influence on test-sample classification. If the value of $\mathrm{k}$ is too large, there is the tendency for classes that are associated with larger sampling populations to have an overwhelming influence on test-sample classification (Drummond et al., 2010). Because there is not a widely accepted formula for determining the optimum $\mathrm{k}$ value and attempts at such are complicated, the example of Drummond, et al., 2010 was followed where a series of 5 different $\mathrm{k}$ values $(5,10,15,20,25)$ were tested (Hall, et al., 2008). These $\mathrm{k}$ values were used in conjunction with seven different log-curve assemblages to create 35 uniquely trained classifier models. After initial evaluation of the trained classifiers' ability to predict the five original architectural-element classes as described in core, a simplified four-class architectural-element realization was created and tested in the manner described above.

Probabilistic Clustering Procedure

In the PCP an initial model is created wherein core-defined architectural-element classes and their associated well-log-curve values are stored as sampling points. For consistency, the same core-depth sampling points as well as the same well-log-curve assemblages used in training the k-NN classifier were used to train the PCP classifier. In the imposed model, the frequency 
distribution of each selected well-log curve is segregated into a user-defined number of pseudoGaussian distributions that represent each desired electrofacies class ( $N=4$ and 5 in this study). These pseudo-Gaussian distributions are plotted as clusters or "modes" in n-dimensional space, with $\mathrm{n}$ being dependent on the number of well-log curves used (Vallejo, 2010; Eslinger and Everett 2012) (Figure 5). During the clustering process a probability density function is employed to calculate the likelihood that each sample belongs to a particular electrofacies class. The sampling points obtained from core description that are used in the calibration of the model are initially assigned a probability of 1.0. Data from the testing wells were withheld from the calibration process so that they would not influence the initial model. In order to incorporate the data from the test cores so that electrofacies-class predictions can be made, at least one adjusting calculation (one iteration) must be made in which a new probability density function is computed. This iteration not only assigns electrofacies-class probabilities in the test cores, but may also change the class-assignment probabilities of the training samples. Generally, when greater numbers of iterations are computed there exists a higher chance that the training samples will be reassigned to a new electrofacies class (Vallejo, 2010; Eslinger and Boyle 2011). For this reason, all of the models tested using the PCP in this study were only allowed the minimum requirement of one iteration. The final classification given to samples in the testing wells is determined by the electrofacies class that is calculated to have the highest probability.

In addition to using the selected well-log curves as variables in the clustering process, an attempt was made to capture grain-size trends as a clustering variable with the intention of better distinguishing between the crevasse splay and the single-story channel body architectural element classes which typically display coarsening upwards and fining upwards grain-size trends, respectively (Cole and Cumella, 2005). The GR well-log curve was selected for this 

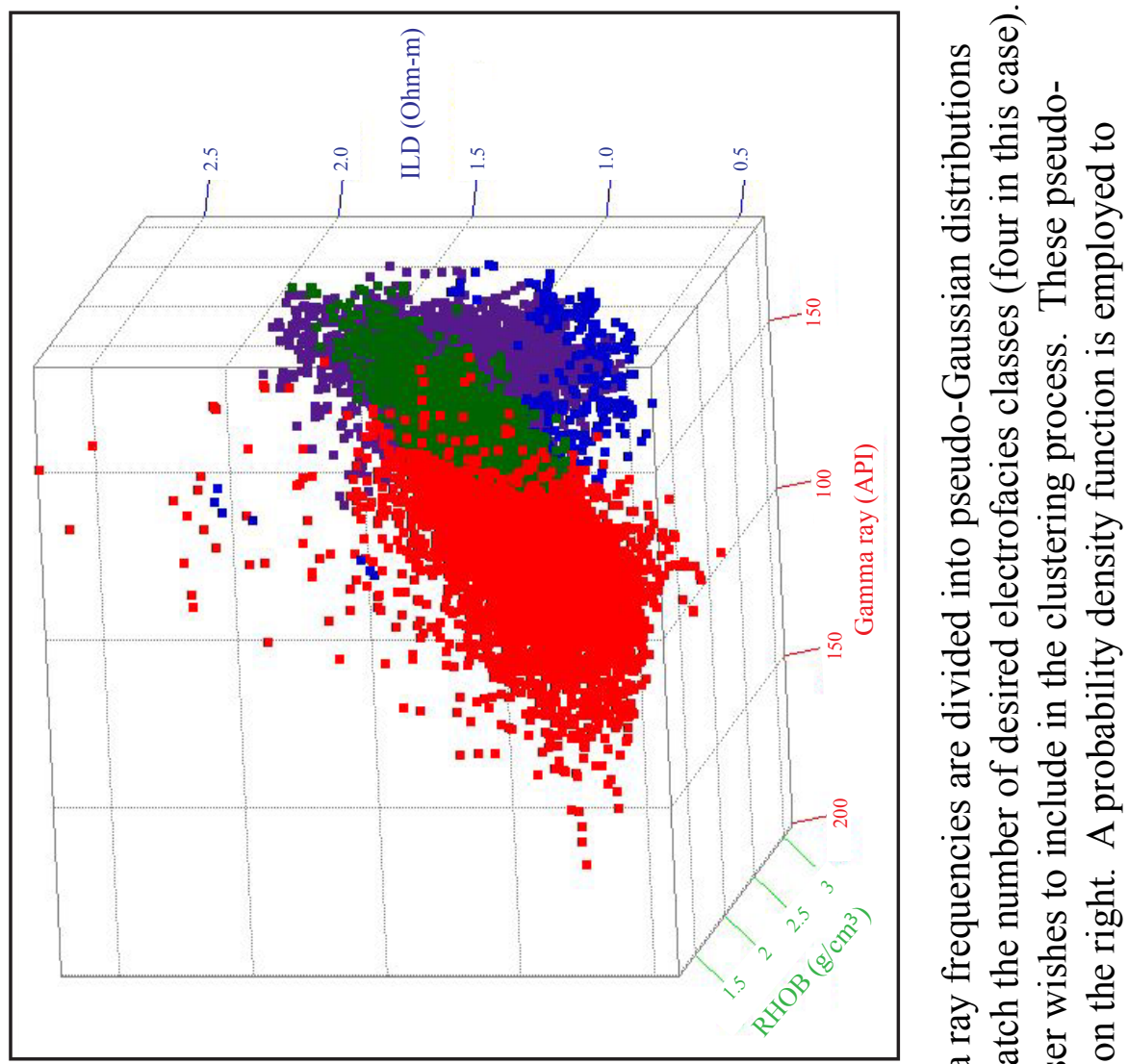

$\exists$ 을 을 을

क ज F ब

उ

$0 \frac{\pi}{0}$ d

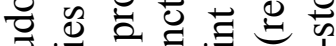

跑

뉴유.二

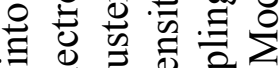

. $\frac{0}{0}$ ग

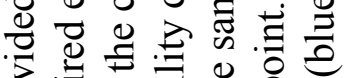

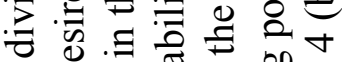

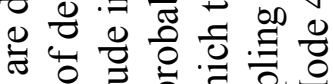

\&

司

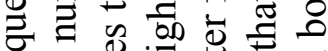

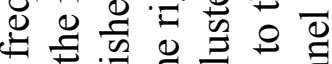

究过它

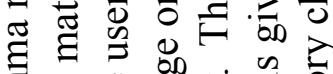

苂

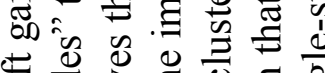

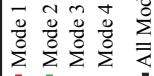

$\leftarrow$ 屯

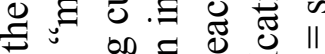

‡)

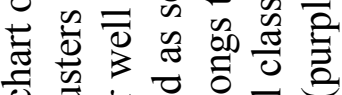

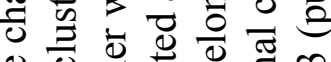

0 ग

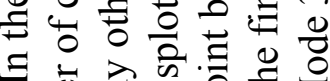

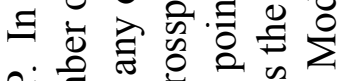

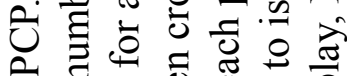

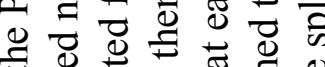

¿

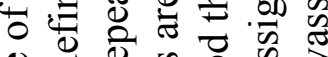

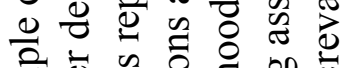

음

突点

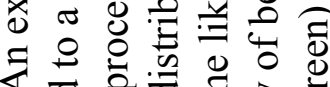

娄导

in 0 范

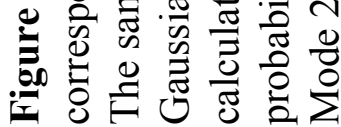

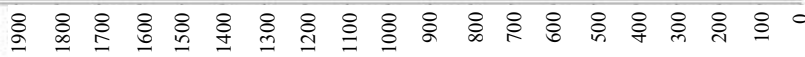


purpose because these grain-size trends are often reflected in its log motif, which is frequently utilized in the manual interpretation of these architectural elements (Hamilton and Galloway, 1989). Using a transform function, the GR curve of the training and testing wells was first smoothed to varying degrees until the resulting curve featured little to no small scale $(\sim 0.5-1 \mathrm{ft}$ $[0.15 \mathrm{~m}-0.30 \mathrm{~m}])$ curve-shape rugosity yet retained an overall grain-size trend representative of the architectural elements being examined. To mimic the grain-size trend, a first derivative transform was computed for the smoothed GR curves over successive $1 \mathrm{ft}(0.03 \mathrm{~m})$ intervals to create windows of investigation ranging from $1 \mathrm{ft}-10 \mathrm{ft}(0.03 \mathrm{~m}-3.04 \mathrm{~m})$. These windows were chosen based on average thicknesses of the crevasse splay $(2.8 \mathrm{ft}[0.85 \mathrm{~m}])$ and single-story channel body ( $8.8 \mathrm{ft}[2.7 \mathrm{~m}])$ architectural elements as observed in outcrop. A computed negative slope over these windows would correspond to a fining upwards grain-size trend whereas a positive slope would correspond to a coarsening upwards grain-size trend. The PCP was carried out again, using the first derivative transforms as variables paired with the different log-curve assemblages.

\section{Thickness Criteria Approach}

Past studies of the Mesaverde Group in the Piceance Basin have established discreet relationships between the fluvial channel body and crevasse splay architectural elements and their respective thicknesses (Cole and Cumella, 2005; German 2006; Pranter, et al., 2009). These relationships were incorporated in the refinement of classification results by applying a method involving an indicator flag which pairs the results of the electrofacies classifiers with thickness criteria. The method is based around a code written in IHS Petra ${ }^{\mathrm{TM}}$ which allows the thickness of a user defined well-log value to be "counted" from top to bottom while unspecified values or "gaps" can be overlooked if they fall below a pre-defined thickness limit. If the well- 
log value being counted passes a gross-thickness requirement (thickness including gaps which fall below the pre-defined thickness limit) and a net-thickness requirement (thickness of user defined value excluding gaps) then an indicator flag is created denoting a newly assigned class (M. Uland, 2013, personal communication). This method was applied to the classifier which garnered the highest overall accuracy for the simplified four-class architectural-element realization to help distinguish between the crevasse splay, single-story channel body, and multistory channel body classes. Thickness criteria are based on average thickness values of architectural elements as observed in outcrop at Coal Canyon, Colorado by (Cole and Cumella, 2005). The workflow for the thickness criteria approach is as follows: 1) Test wells in which electrofacies have been predicted by the classifier are imported into IHS Petra' ${ }^{\mathrm{TM}}$ as .las files with each predicted electrofacies corresponding to a representative value $(1=$ floodplain, $2=$ crevasse splay, 3 = single-story channel body, 4 = multi-story channel body); 2) A multi-story channel flag is created using a gross-thickness requirement of $12 \mathrm{ft}(3.66 \mathrm{~m})$ which is set at roughly two feet less than the average thickness of a multi-story channel body $(13.8 \mathrm{ft}[4.21 \mathrm{~m}])$ such that the thickness requirement is slightly more inclusive than the average thickness value. A netthickness requirement of $9 \mathrm{ft}(2.74 \mathrm{~m})$ was deemed appropriate based on visual inspection of classifier results in well-log form, and the maximum acceptable gap was set at $4 \mathrm{ft}(1.22 \mathrm{~m})$ based on previous utilization of this method by (M. Uland, 2013, personal communication); 3) After the multi-story channel body flag has been established, a simplified three-class .las log curve is created which consists of i) the floodplain electrofacies, ii) a new class that combines the crevasse splay electrofacies, the single-story channel body electrofacies, and any interval that was previously classified as a multi-story channel body but did not pass the thickness requirements necessary to be considered part of the multi-story flag, and iii) the multi-story 
channel body flag just created; 4) A single-story channel body indicator flag is then applied to this new simplified .las log curve using a gross-thickness requirement of $7 \mathrm{ft}$ (2.13 m) which, like was done for the multi-story channel body indicator flag, is set at approximately two feet less than the average thickness of a single-story channel body $(8.8 \mathrm{ft}[2.68 \mathrm{~m}])$ such that the thickness requirement is slightly more inclusive than the average thickness value. A net-thickness value of $4 \mathrm{ft}(1.22 \mathrm{~m})$ was chosen based on visual inspection of classifier results, and the maximum acceptable thickness gap was kept to $0.5 \mathrm{ft}(0.15 \mathrm{~m})$ so as to eliminate any small erroneous classification spikes while not allowing the grouping of closely stacked similar electrofacies. Within this simplified three-class .las log curve, if an interval of values belonging to the second class (ii) does not meet the minimum thickness requirements to be flagged as a single-story channel body, it is classified as a crevasse splay; 5) A final .las log curve is created that merges the two channel flags with the floodplain and crevasse splay classes. A coal flag was also created with the criteria GR $<75$ API and RHOB $<2.1 \mathrm{~g} / \mathrm{cm}^{3}$ and merged along with these classes into the final .las log curve (Appendix G).

\section{Results}

Through an approach which combined selected classifier results with the thickness criteria approach, an overall accuracy of $83.6 \%$ was achieved. The individual architectural elements of the simplified four-class architectural-element realization were predicted with user's accuracies of $0.891,0.376,0.735$, and 0.985 for the floodplain, crevasse splay, single-story channel body, and multi-story channel body classes, respectively. Such a methodology could provide an alternative approach to the classification of fluvial architectural elements in commonly available well logs (Figure 6). 


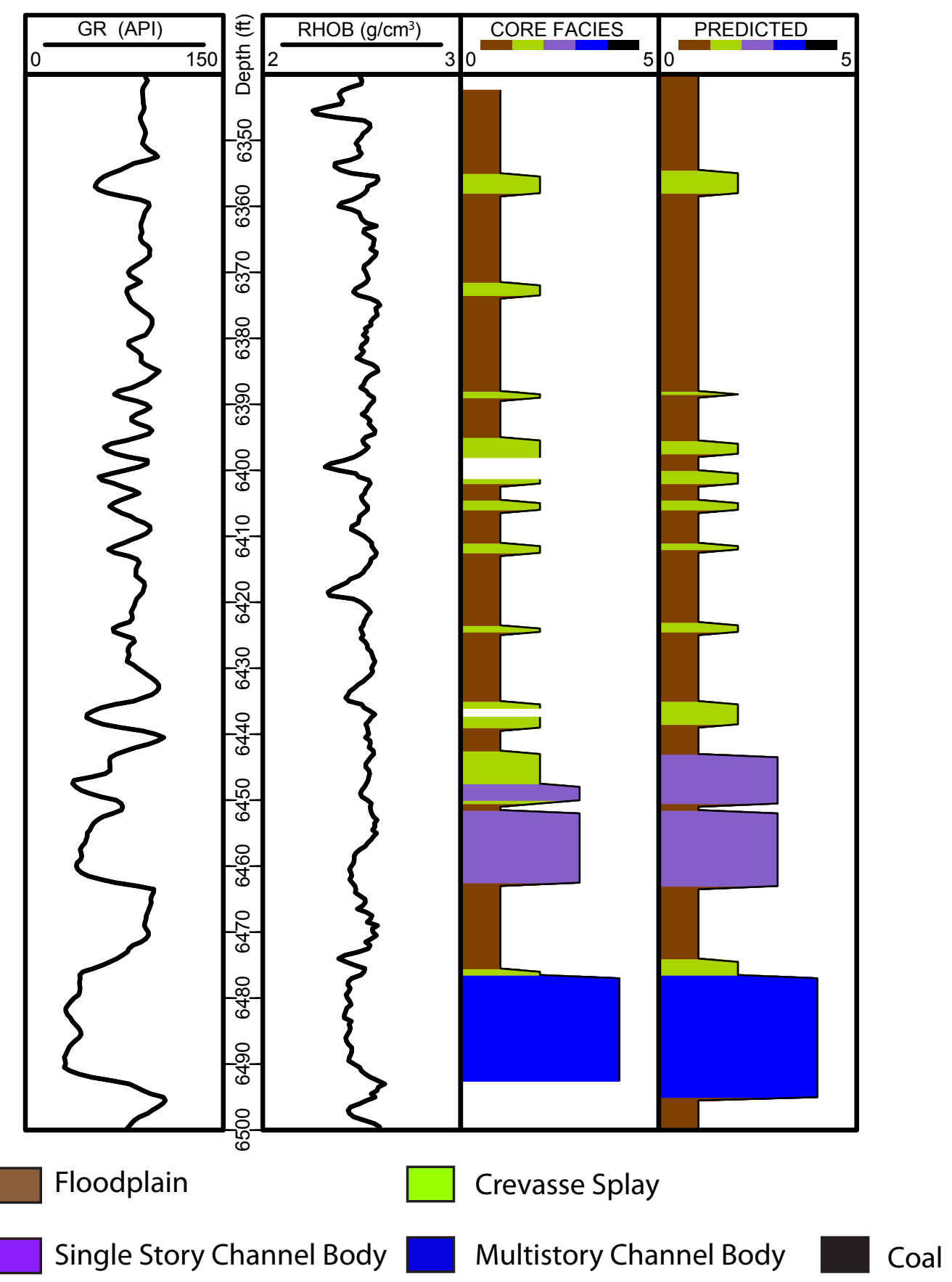

Figure 6: The well-log curve of the far right column features the resulting architectural elements as predicted in a section of test well NBU-21 by the coupling of the well-logindicator flag approach with the results of the k-NN classifier as trained by the well-log curves GR and RHOB. This is compared with a well-log curve to its left in which the actual core-described architectural elements are featured. 
Prediction Performance of the k-NN Method

Evaluation of the variably trained (varying log-curve assemblages and k values) k-NN classifiers' ability to correctly predict the occurrence of the five architectural elements as they exist in the testing wells rendered a best case overall accuracy of $63.8 \%$ with the floodplain, crevasse splay, single-story channel body, multi-story channel body, and amalgamated channel body yielding individual user's accuracies of $0.897,0.624,0.026,0.228$, and 0.904 respectively (Figure 7) (Appendix H). While the k-NN classifier faired quite well in its ability to predict the floodplain, crevasse splay, and amalgamated channel body architectural elements, the singlestory channel body and multi-story channel body architectural elements were rarely predicted correctly. An examination of inter-class confusion in all of the k-NN tests revealed a high degree of confusion between the single-story channel body and crevasse splay architectural elements as well as a high degree of confusion between the multi-story channel body and amalgamated channel body architectural elements (Figure 7) (Appendix I). A new simplified four-class architectural-element realization was developed in which the highly confused and geologically similar multi-story channel body and amalgamated channel body classes were combined into the same multi-story channel body class. Evaluation of the k-NN classifier's ability to predict the simplified four-class realization resulted in an improved best case overall accuracy of $74.5 \%$ with the floodplain, crevasse splay, single-story channel body, and multistory channel body yielding individual user's accuracies of $0.926,0.539,0.069$, and 0.932 respectively (Figure 8) (Appendix J). Simplification of the architectural element classes also led to an improvement in inter-class confusion marked by a more desirable predicted volume for the newly aggregated multi-story class and a consequently lower average deviation compared to the previously tested five-class architectural-element realization; however, confusion between the 


\section{A User's Accuracy of 5-Class Architectural-Element Realization by k-NN}

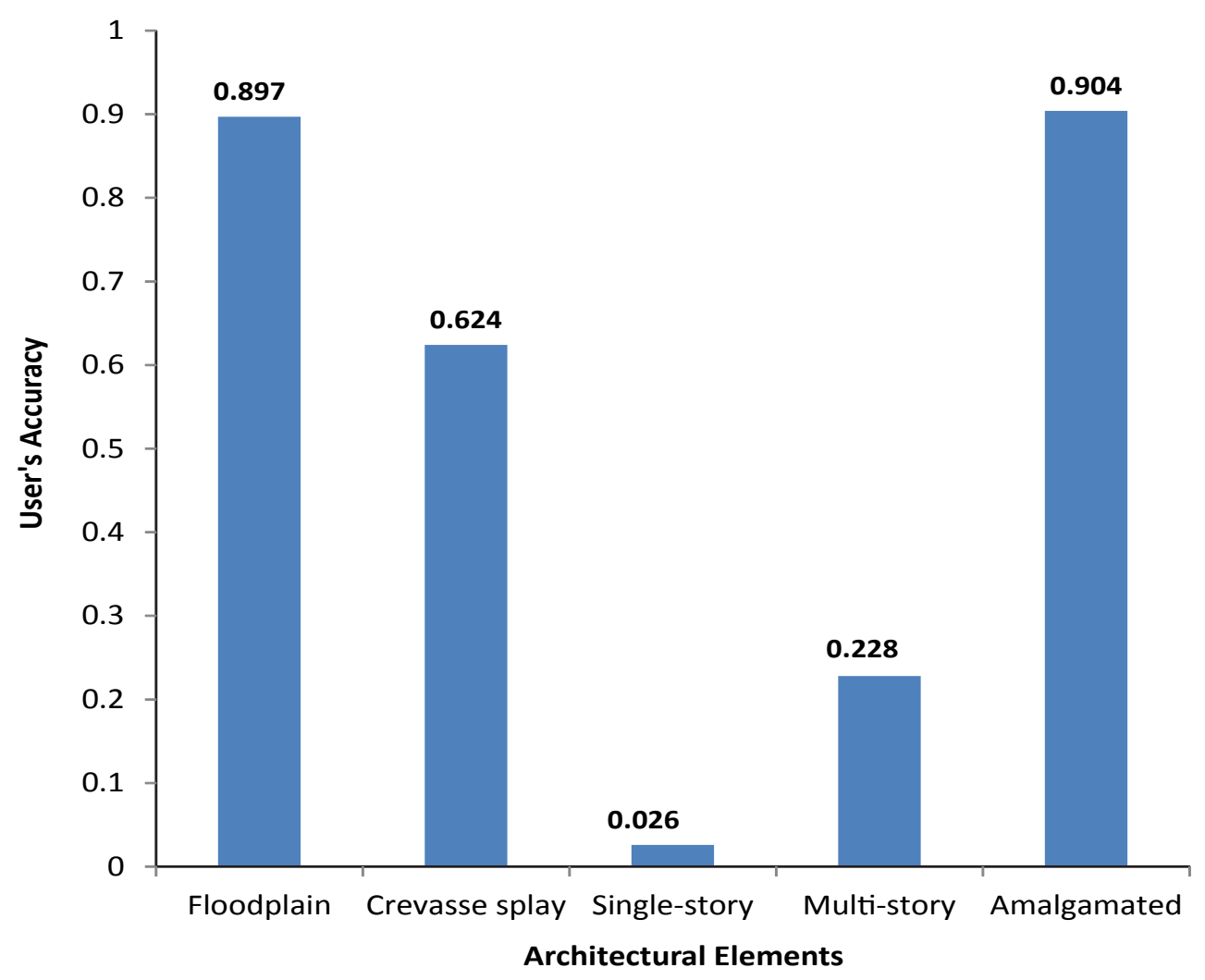

B

Example Confusion Matrix for 5-Class Architectural-Element Realization by k-NN

\begin{tabular}{|l|r|r|r|r|r|r|}
\hline \multirow{2}{*}{ Actual Class } & \multicolumn{7}{|c|}{ Predicted Class } & Actual Class Sum \\
\cline { 2 - 8 } & FP & CS & SS & MS & AM & \\
\hline FP & 411 & 46 & 0 & 0 & 1 & 458 \\
\hline CS & 32 & 88 & 0 & 1 & 20 & 141 \\
\hline SS & 1 & 132 & 5 & 8 & 43 & 189 \\
\hline MS & 0 & 18 & 12 & 36 & 92 & 158 \\
\hline AM & 0 & 4 & 0 & 19 & 217 & 240 \\
\hline Column Total & 444 & 288 & 17 & 64 & 373 & 1186 \\
\hline Predicted Volume & $97 \%$ & $204 \%$ & $9 \%$ & $41 \%$ & $155 \%$ & \\
\hline
\end{tabular}


Figure 7: (A) Graphical display of the user's accuracies for the five class architectural-element realization produced by the k-NN classifier trained by the log curve assemblage GR, RHOB, NPHI and $\mathrm{k}$ value of 20 - one of two variably trained k-NN classifiers to produce the highest overall accuracy achieved (63.8\%) for the five class architectural element realization. These user accuracies are similar to those achieved by the other well-log-curve assemblages for the $\mathrm{k}-\mathrm{NN}$ classifier (Appendix H). (B)The confusion matrix assocatied with the $\mathrm{k}-\mathrm{NN}$ classifier that was trained using the well-log curves GR, RHOB,RT, and NPHI and a k value of 20 which produced an overall accuracy of $63.8 \%$ achieved when attempting to predict the five architectural-element classes ( $\mathrm{FP}=$ floodplain, $\mathrm{CS}=$ crevasse splay, $\mathrm{SS}=$ single-story channel body, $\mathrm{MS}=$ multi-story channel body, $\mathrm{AM}$ = amalgamated channel body). Yellow highlighted cells represent the number of correctly predicted samples out of the actual class sum while the other cells within the row represent the mis-classified architectural elements. High inter-class confusion is observed between CS and SS where 132 out of 189 total SS samples are incorrectly classified as the CS class. A high degree of confusion is also observed between the MS and AM classes with 92 out of 158 MS samples being incorrectly classified as the AM class. This confusion is also represented by the high predicted volumes of the CS and AM classes and the low predicted volumes of the SS and MS classes which contributed to an average deviation value of 62.6. The distribution of values seen in this matrix is similar to the distributions found the other variably trained $\mathrm{k}-\mathrm{NN}$ classifiers for the five class architectural-element realization (Appendix I). 


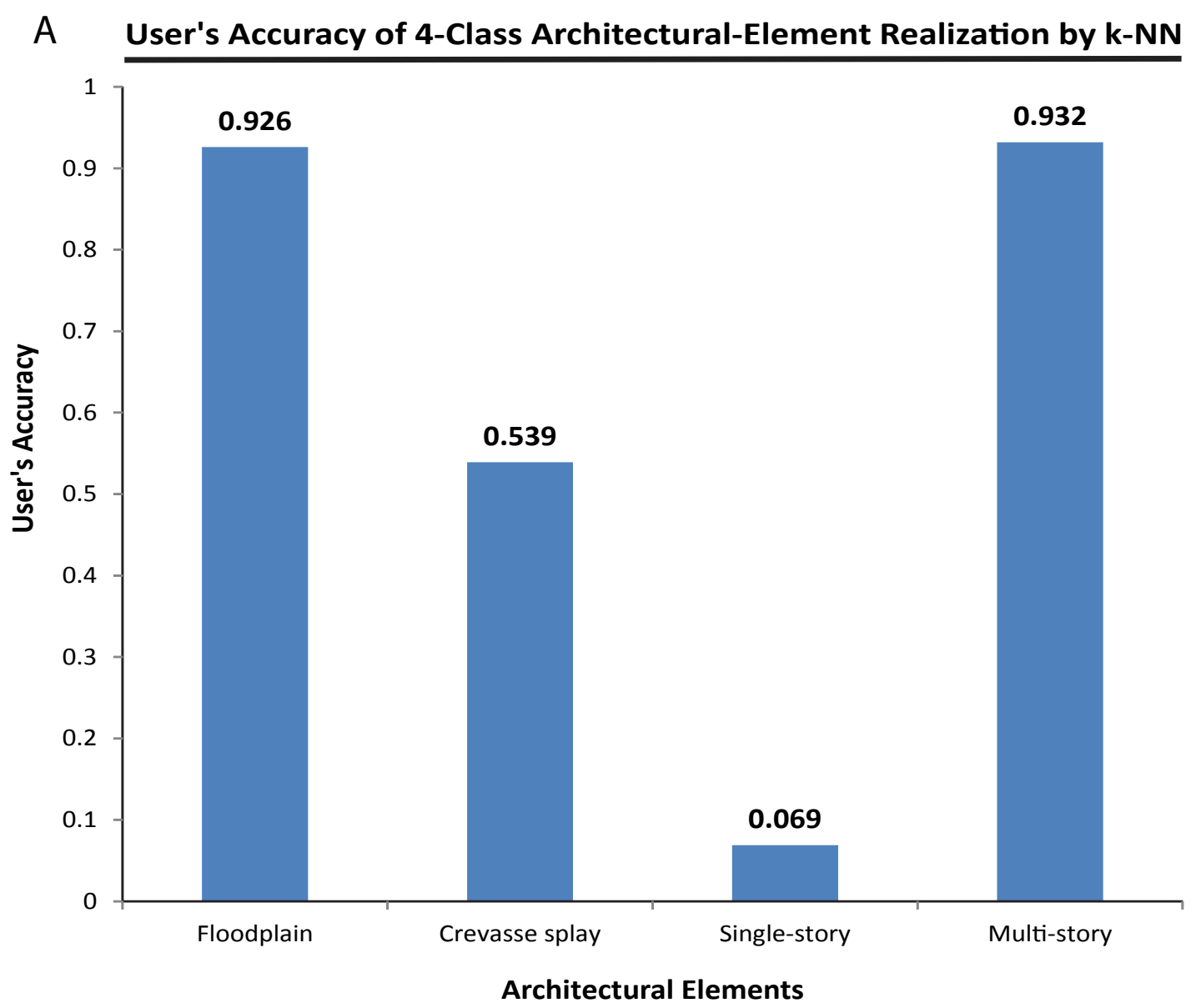

B

Example Confusion Matrix for 4-Class Architectural-Element Realization by k-NN

\begin{tabular}{|c|c|c|c|c|c|}
\hline \multirow[b]{2}{*}{ Actual Class } & \multicolumn{4}{|c|}{ Predicted Class } & \multirow{2}{*}{ Actual Class Sum } \\
\hline & FP & CS & SS & MS & \\
\hline FP & 424 & 33 & 0 & 1 & 458 \\
\hline CS & 35 & 76 & 1 & 29 & 141 \\
\hline SS & 10 & 111 & 13 & 55 & 189 \\
\hline MS & 0 & 26 & 1 & 371 & 158 \\
\hline Column Total & 469 & 246 & 15 & 456 & 240 \\
\hline Predicted Volume & $102 \%$ & $174 \%$ & $8 \%$ & $115 \%$ & 1186 \\
\hline
\end{tabular}


Figure 8: (A) Graphical display of the user's accuracies for the four class architectural-element realizationproduced by the k-NN classifier trained by the log curve assemblage GR, RHOB and $\mathrm{k}$ value of 20 - one of two variably trained k-NN classifiers to produce the highest overall accuracy achieved (62\%) by the PCP classifier for the five class architectural element realization. These user accuracies are similar to those achieved by the other well-log-curve assemblages for the PCP (Appendix J). (B) The confusion matrix assocatied with the k-NN classifier that was trained using the well-log-curve assemblage GR, RHOB and a $\mathrm{k}$ value of 20 which produced an overall accuracy of $74.5 \%$ achieved when attempting to predict the four architectural-element classes $(\mathrm{FP}=$ floodplain, $\mathrm{CS}=$ crevasse splay, $\mathrm{SS}=$ single-story channel body, MS = multi-story channel body). Yellow highlighted cells represent the number of correctly predicted samples out of the actual class sum while the other cells within the row represent the mis-classified architectural elements. Simplification of the five class architectural-element realization by combining the AM and MS classes into a single class resulted in a comparatively lower degree of inter-class confusion denoted by a more desirable predicted volumefor the newly aggregated multi-story channel body class which contributed to a reduced average deviation value of 45.9. A high degree of inter-class confusion is still observed between the CS and SS classes where 111 out of 189 total SS samples are incorrectly classified as the CS class. The distribution of values seen in this matrix is similar to the distributions found the other variably trained k-NN classifiers for the four class architecturalelement realization (Appendix K). 
single-story channel body and crevasse splay architectural-element classes still remained high (Figure 8) (Appendix K). Observations of the success of the varying well-log-curve assemblages and $\mathrm{k}$ values in distinguishing the original five architectural elements classes were ignored in favor of focusing on the role of these variables in distinguishing between the classes of the more geologically realistic four-class architectural-element realization. The range in overall accuracy values produced by the seven well-log-curve assemblages tested was not large, and no one welllog-curve assemblage predicted an individual architectural-element class markedly better than the others (Appendix J). However, the well-log-curve assemblages of GR, RHOB and GR, RHOB, ILD are associated with the identical highest overall accuracies achieved. The addition of the ILD well-log curve seemed to have had little to no effect on the outcome of the predictions, indicating that the GR and RHOB curves are primarily responsible for the success of the predictions (Figure 9) (Appendix J). Testing of the five different $\mathrm{k}$ values $(5,10,15,20$, and 25 ) with the various well-log-curve assemblages revealed a general increase in overall accuracy up to the $\mathrm{k}$ value of 20 followed by a decline in overall accuracy at the $\mathrm{k}$ value of 25 in the majority of cases (Figure 10). This trend in overall accuracy is mirrored by the user's accuracies of the individual architectural elements with the exception of the single-story channel body which often decreases in user's accuracy with successively larger k values (Appendix J). The classifiers trained by the combination of these optimal variables of $k=20$ and the well-log-curve assemblage of GR and RHOB are responsible for producing the best case results for the four class architectural-element realization which were previously mentioned.

\section{Prediction Performance of the PCP Classifier}

Like the k-NN method when evaluated for its ability to distinguish the original five architectural elements, the PCP proved capable of predicting the floodplain, crevasse splay, and 


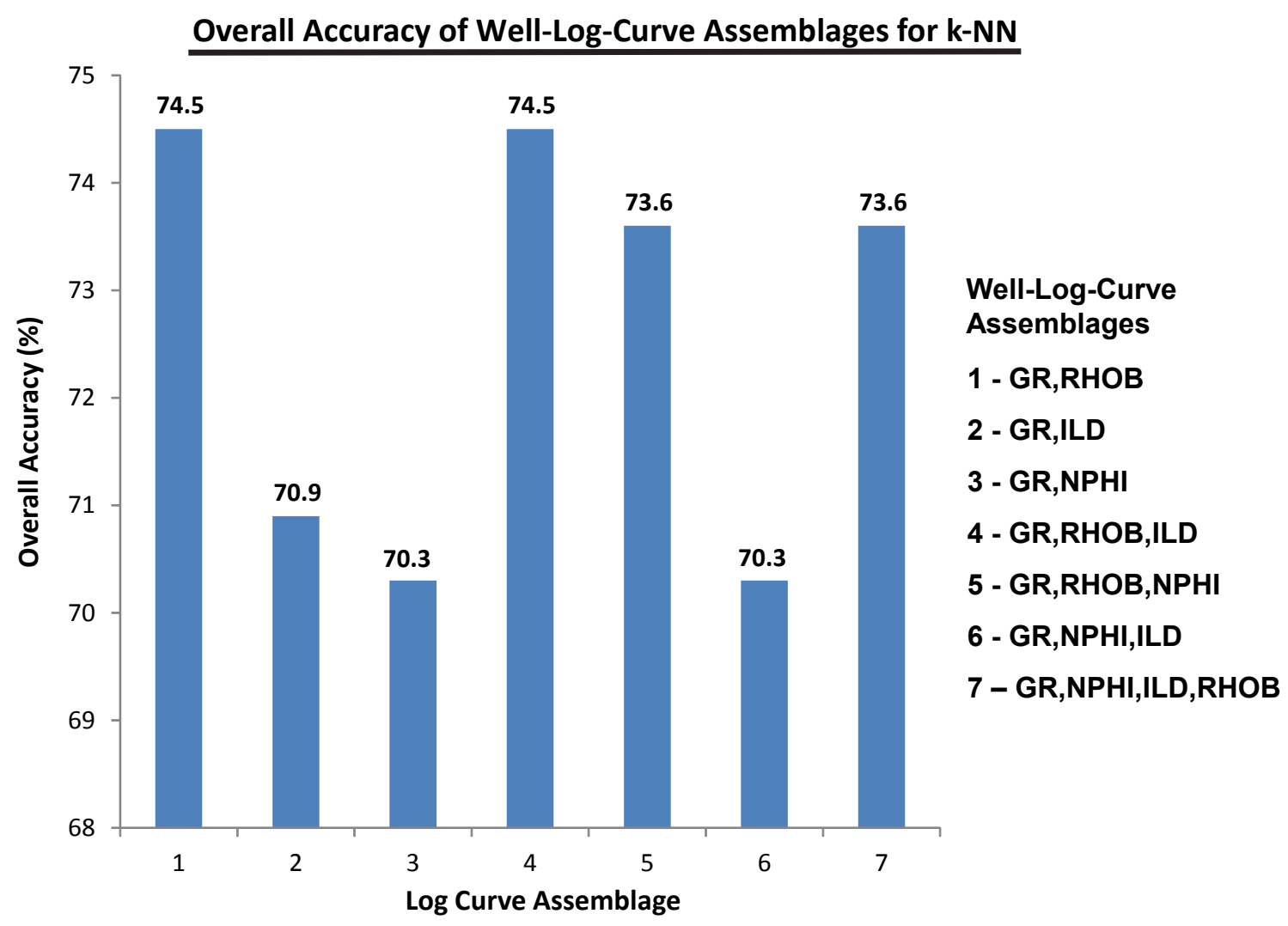

Figure 9: A graphical display of the highest overall accuracy achieved for each well-logcurve assemblage for the four class architectural-element realization using the k-NN method. The well-log-curve assemblages containing GR, RHOB and GR, RHOB, ILD produced the highest overall accuracies. Assemblages which had ILD added to them, showed no change in overall accuracy. 


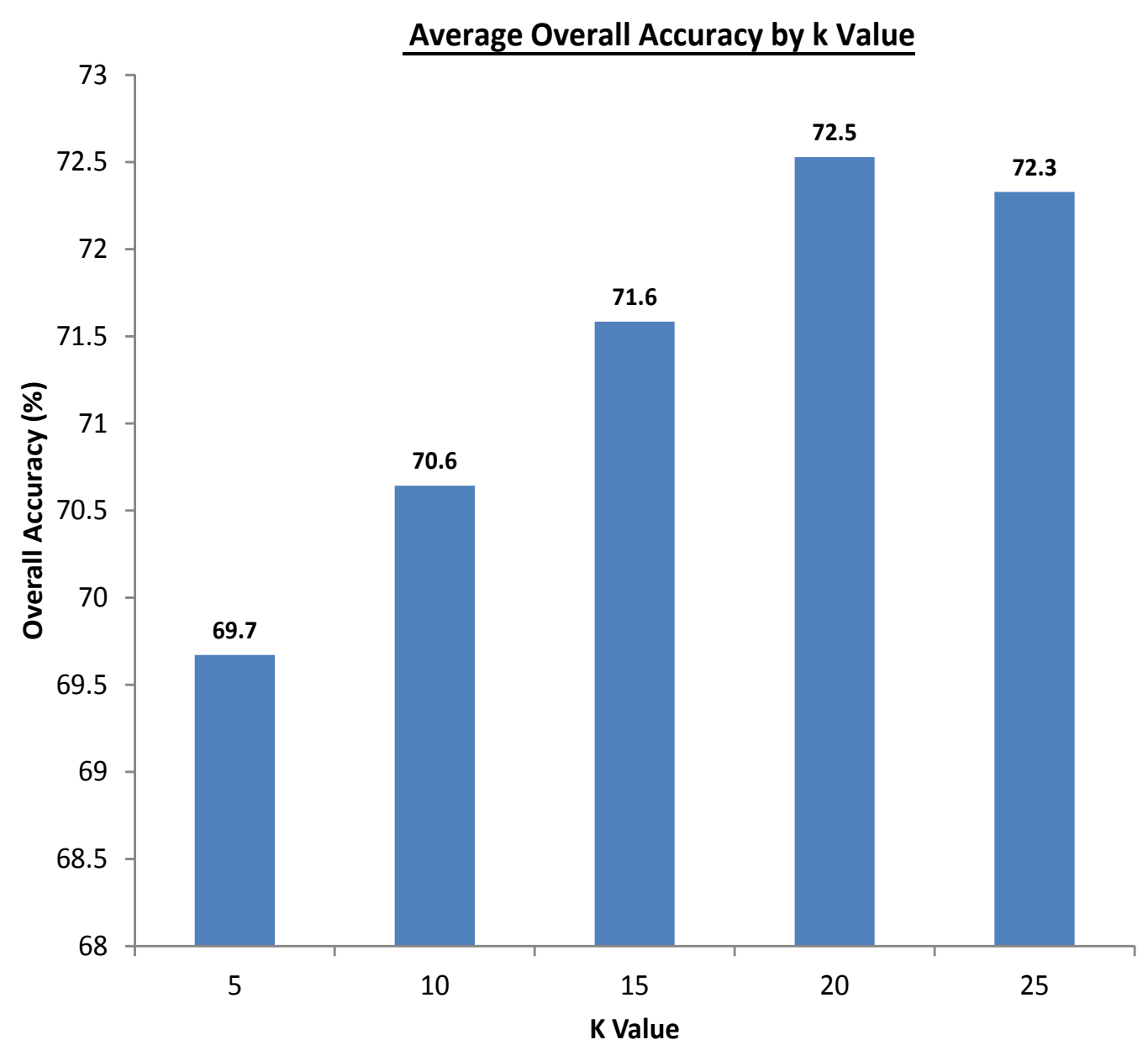

Figure 10: A graphical display of the averaged overall accuracies achieved by each $k$ value for the various well-log-curve assemblages. An average of the overall accuracies for each $\mathrm{k}$ value over the different well-log-curveassemblages was taken to summarize the trend seen amongst the majority of the well-log-curve assemblages when the successively larger $\mathrm{k}$ values were tested. User accuracies on a case-by-case basis can be found in Appendix I. 
amalgamated channel body architectural elements with moderate to high user's accuracies which contributed to a best case overall accuracy of $62 \%$. However, the single-story channel body and multi-story channel body were rarely predicted correctly by the PCP (Figure 11) (Appendix L). Analysis of inter-class confusion revealed that the single-story channel body was commonly incorrectly predicted as both the crevasse splay and amalgamated channel body architectural elements. A high degree of confusion between the multi-story channel body and amalgamated channel body architectural elements was also observed (Figure 11) (Appendix M). As was done during the testing of the k-NN method, the PCP was tested for its ability to predict classes in a simplified four-class architectural-element realization which combines the highly confused and geologically similar multi-story channel body and amalgamated channel body classes. Once again the simplified four-class architectural-element realization lent itself to the alleviation of some degree of inter-class confusion denoted by lower average deviation values attributed to more ideal predicted volumes of the newly aggregated multi-story class (Figure 12) (Appendix N). Though success metrics for the multi-story class improved, the single-story channel body is still almost never predicted correctly (Figure 12) (Appendix O). Of the seven well-log-curve assemblages tested, none produced dramatically better overall accuracies than the others; however, even though the difference is small, the well-log-curve assemblages GR, RHOB and GR, RHOB, ILD are associated with the highest overall accuracies achieved by the PCP classifier of 72.8\% (Figure 13). Again, the ILD well-log curve seemed to have little to no effect on the accuracy of the predictions suggesting the GR and RHOB well-log curves are primarily responsible for the success of the predictions. With the PCP classifier, none of the seven welllog-curve assemblages showed an advantage over the others in their ability to predict the individual architectural-element classes with the exception that those assemblages which 


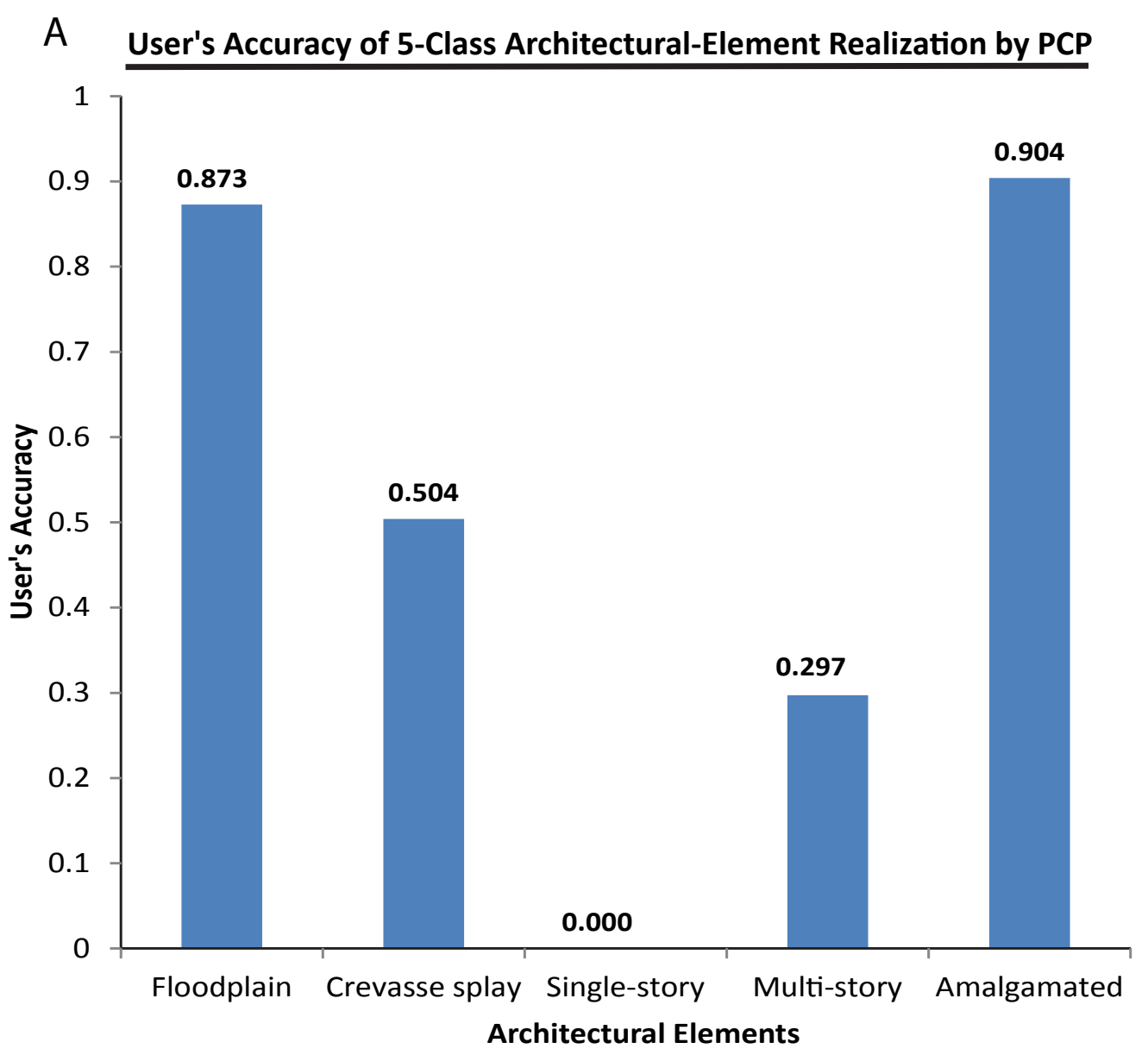

B

Example Confusion Matrix for 5-Class Architectural-Element Realization by PCP

\begin{tabular}{|l|r|r|r|r|r|r|}
\hline \multirow{2}{*}{ Actual Class } & \multicolumn{7}{|c|}{ Predicted Class } & Actual Class Sum \\
\cline { 2 - 8 } & FP & CS & SS & MS & AM & \\
\hline FP & 400 & 39 & 0 & 0 & 19 & 458 \\
\hline CS & 34 & 71 & 0 & 7 & 29 & 141 \\
\hline SS & 5 & 80 & 0 & 21 & 83 & 189 \\
\hline MS & 2 & 7 & 9 & 47 & 93 & 158 \\
\hline AM & 0 & 2 & 0 & 21 & 217 & 240 \\
\hline Column Total & 441 & 199 & 9 & 96 & 441 & 1186 \\
\hline Predicted Volume & $96 \%$ & $141 \%$ & $5 \%$ & $61 \%$ & $184 \%$ & \\
\hline
\end{tabular}


Figure 11: (A) Graphical display of the user's accuracies for the five class architecturalelement realizationproduced by PCP classifier trained by the log curve assemblage GR, RHOB, NPHI - one of two log curve assemblages to produce the highest overall accuracy achieved $(62 \%)$ by the PCP classifier for the five class architectural element realization. These user accuracies are similar to those achieved by the other well-log-curve assemblages for the PCP (Appendix L). (B) The confusion matrix assocatied with the PCP classifier that was trained using the well-log curves GR, RHOB, NPHI which produced an overall accuracy of $62 \%$ achieved when attempting to predict the five architectural element classes (FP = floodplain, $\mathrm{CS}=$ crevasse splay, $\mathrm{SS}=$ single-story channel body, MS = multi-story channel body, $\mathrm{AM}=$ amalgamated channel body). Yellow highlighted cells represent the number of correctly predicted samples out of the actual class sum while the other cells within the row represent the mis-classified architectural elements. The SS class is observed to be frequently misclassified as the CS and AM classes. A high degree of confusion is also observed between the MS and AM classes with 93 out of 158 MS samples being incorrectly classified as the AM class. This confusion is also represented by the high predicted volumes of the CS and AM classes and the low predicted volumes of the SS and MS classes which contributed to an average deviation value of 52.6. The distribution of values seen in this matrix is similar to the distributions found by the other variably trained PCP classifiers for the five class architectural-element realization (Appendix M). 


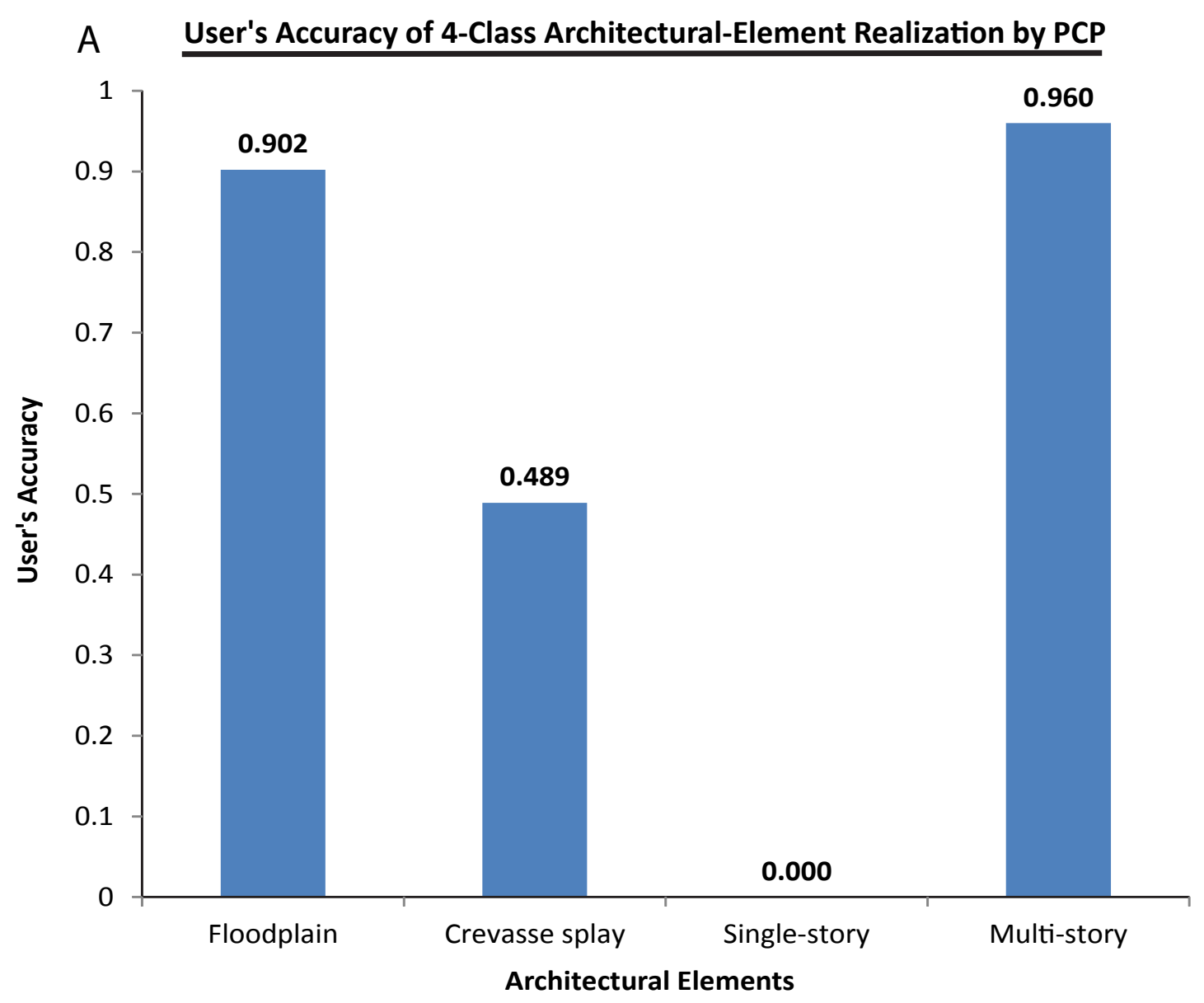

B

Example Confusion Matrix for 4-Class Architectural-Element Realization by PCP

\begin{tabular}{|c|c|c|c|c|c|}
\hline \multirow[b]{2}{*}{ Actual Class } & \multicolumn{4}{|c|}{ Predicted Class } & \multirow[t]{2}{*}{ Actual Class Sum } \\
\hline & FP & CS & SS & MS & \\
\hline FP & 413 & 38 & 0 & 7 & 458 \\
\hline CS & 36 & 69 & 0 & 36 & 141 \\
\hline SS & 11 & 69 & 0 & 109 & 189 \\
\hline MS & 0 & 16 & 0 & 382 & 158 \\
\hline Column Total & 460 & 192 & 0 & 534 & 240 \\
\hline Predicted Volume & $100 \%$ & $136 \%$ & $0 \%$ & $134 \%$ & 1186 \\
\hline
\end{tabular}


Figure 12: (A) Graphical display of the user's accuracies for the four class architectural-element realizationproduced by PCP classifier trained by the log curve assemblage GR, RHOB - one of two log curve assemblages to produce the highest overall accuracy achieved $(72.8 \%)$ by the PCP classifier for the four class architectural element realization. These user accuracies are similar to those achieved by the other well-log-curve assemblages for the PCP (Appendix O). (B) The confusion matrix assocatied with the PCP classifier that was trained using the well-log-curve assemblage GR, RHOB which produced an overall accuracy of $72.8 \%$ achieved when attempting to predict the four architectural element classes ( $\mathrm{FP}=$ floodplain, $\mathrm{CS}=$ crevasse splay, $\mathrm{SS}=$ single-story channel body, $\mathrm{MS}=$ multi-story channel body).

Yellow highlighted cells represent the number of correctly predicted samples out of the actual class sum while the other cells within the row represent the misclassified architectural elements. Simplification of the five class architectural-element realization by combining the AM and MS classes into a single class resulted in a comparatively lower degree of inter-class confusion denoted by a more desirable predicted volume for the newly aggregated multi-story channel body class which contributed to a reduced average deviation value of 42.7. The SS class still remains highly confused with the CS and MS classes. The distribution of values seen in this matrix is similar to the distributions found by the other variably trained PCP classifiers for the four class architectural-element realization (Appendix N). 


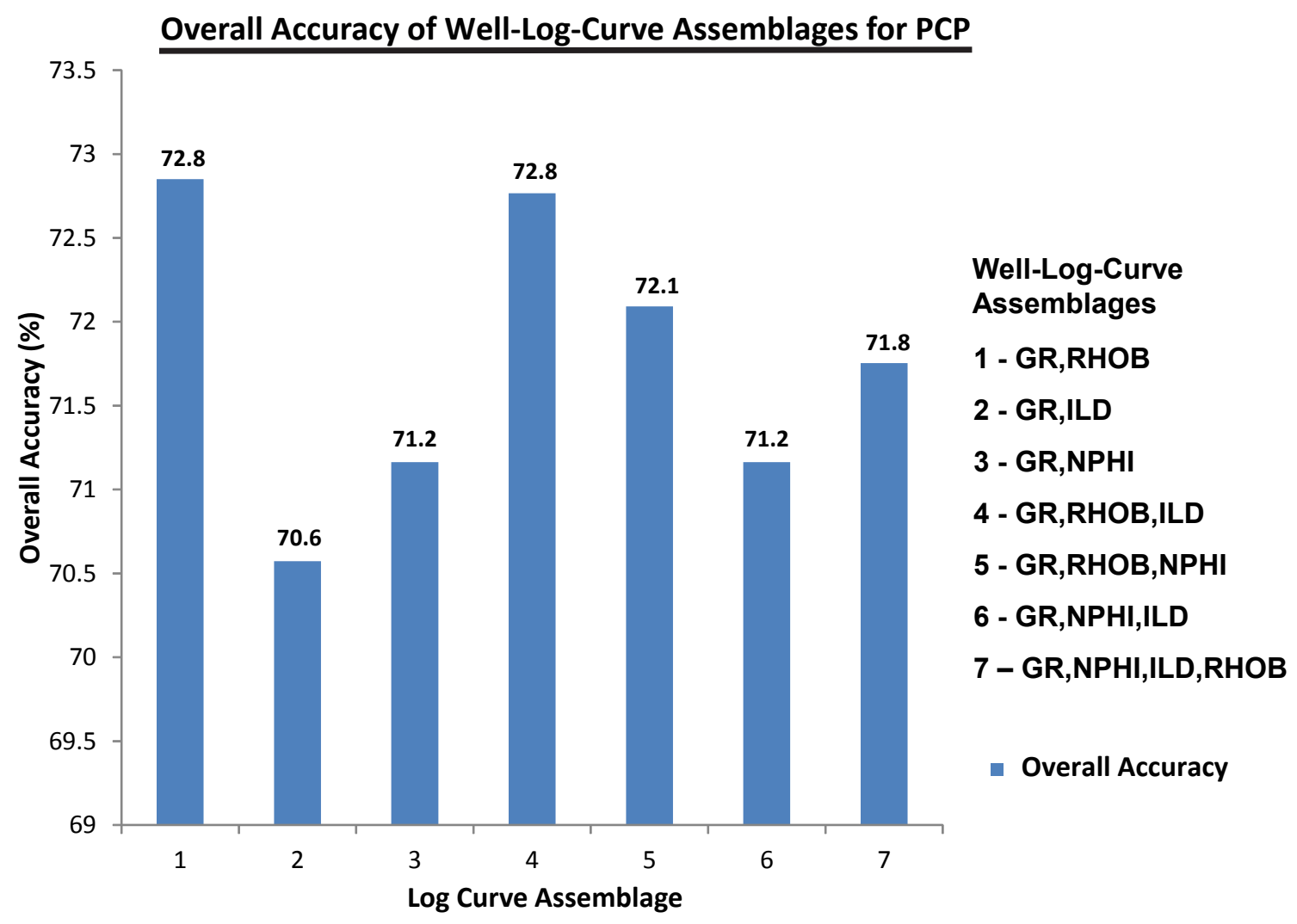

Figure 13: A graphical display of the highest overall accuracy achieved for each well-logcurve assemblage forthe four class architectural-element realization using the PCP classifier. The well-log-curve assemblages containing GR , RHOB and GR, RHOB, ILD produced the highest overall accuracies. 
included the RHOB curve were more effective at predicting the crevasse splay architecturalelement class than those which did not include it (Appendix O). Efforts to better distinguish between the highly confused crevasse splay and single-story channel body architectural-element classes by attempting to capture the distinctive grain-size trends of these classes as a classifier variable through a first derivative transform proved to be unfruitful, with prediction results resembling noise (Appendix P).

Refinement of Classifier Results with the Thickness Criteria Approach

Though both classifiers were shown to be capable of predicting the floodplain, crevasse splay, and multi-story channel body classes with satisfying accuracy in the simplified four-class architectural-element realization, attempts by both classifiers failed to accurately predict the single-story channel-body class which was always highly confused for the crevasse splay and/or multi-story channel-body classes. After applying the thickness criteria approach to the classifier result having the best overall accuracy (k-NN classifier trained by well-log-curve assemblage GR, RHOB and $\mathrm{k}=20$ ), the previously troubled single-story channel body class was now predicted with a 0.735 user's accuracy - bringing the overall accuracy to a new high of $83.6 \%$. The improvement in accuracy metrics is owed to a reduction in inter-class confusion made possible by the incorporation of thickness criteria. The single-story channel body class was now much less commonly misclassified as the crevasse splay class; a change that is reflected in more ideal predicted volumes and average deviation value (Table 2). The user's accuracies of the other architectural-element classes remained relatively unchanged compared to their success in the kNN method, with the exception of the crevasse splay which decreased slightly (Appendix Q). A depiction of the well-log curves generated by the thickness criteria approach as compared to 
Confusion Matrix of the combined k-NN and Thickness Criteria Approaches

\begin{tabular}{|c|c|c|c|c|c|}
\hline \multirow[b]{2}{*}{ Actual Class } & \multicolumn{4}{|c|}{ Predicted Class } & \multirow[t]{2}{*}{ Actual Class Sum } \\
\hline & $\overline{F P}$ & CS & SS & MS & \\
\hline FP & 408 & 29 & 7 & 14 & 458 \\
\hline CS & 34 & 53 & 0 & 36 & 141 \\
\hline SS & 9 & 35 & 139 & 6 & 189 \\
\hline MS & 0 & 6 & 0 & 392 & 158 \\
\hline Column Total & 451 & 123 & 166 & 446 & 240 \\
\hline Predicted Volume & $98 \%$ & $87 \%$ & $88 \%$ & $112 \%$ & 1186 \\
\hline
\end{tabular}

Table 2: The confusion matrix resulting from the application of the well-log-indicator flag approach in refining the results of the k-NN classifier that was trained using the well-log curves GR, RHOB and a $\mathrm{k}$ value of 20 . Yellow highlighted cells represent the number of correctly predicted samples out of the actual class sum while the other cells within the row represent the mis-predicted architectural elements. $(\mathrm{FP}=$ floodplain, $\mathrm{CS}=$ crevasse splay, $\mathrm{SS}=$ single-story channel body, MS = multi-story channel body). The incorporation of thickness criteria greatly alleviated inter-class confusion involving the misclassification of the SS architectural-element class. This improvement is reflected in the more ideal predicted volumes achieved and the lowered average deviation value of 9.6 as compared to the average deviation value of the pre-refined k-NN classifier of 45.9. This improvement in inter-class confusion led to an overall accuracy of $83.6 \%$. 
well-log curves representing architectural elements as described in the test cores is shown in figure 14 .

Discussion

Combining Alike Architectural Elements

The resulting architectural-element predictions of the two classification methods displayed many similarities in terms of the accuracies that were achieved as well the inter-class confusion that was revealed upon examination of the confusion matrices. When tested for their ability to distinguish the five architectural elements that were originally described in core, both the k-NN and PCP classifiers showed a high degree of confusion between the multi-story channel body and amalgamated channel body classes (Appendices $\mathrm{H}$ and L). In this study, the use of the term amalgamated channel body was influenced by the observations of this class by Cole and Cumella (2003) at Main Canyon and Plateau Creek Canyon, Colorado and further detailed study by German, 2006 where it was described as the stacked multi-story channel bodies which were thicker (average thickness: $26 \mathrm{ft}[7.9 \mathrm{~m}]$ ) and more laterally extensive (average width of $870 \mathrm{ft}[1265 \mathrm{~m}])$ than a typical multi-story channel body. Beyond scale, which can be difficult to accurately assess in core, the geologic similarity of these two architectural-element classes made their distinction in core a subjective process. The subjectivity of this distinction is likely reflected in the high degree of confusion observed between the two classes. Combining the similar multi-story channel body and amalgamated channel body architectural elements into a single class to create a simplified four-class architectural-element realization seemed a geologically realistic choice given that both of these architectural elements can potentially be deposited by low-to-medium sinuosity fluvial systems (White, et al., 2008). The single-story 


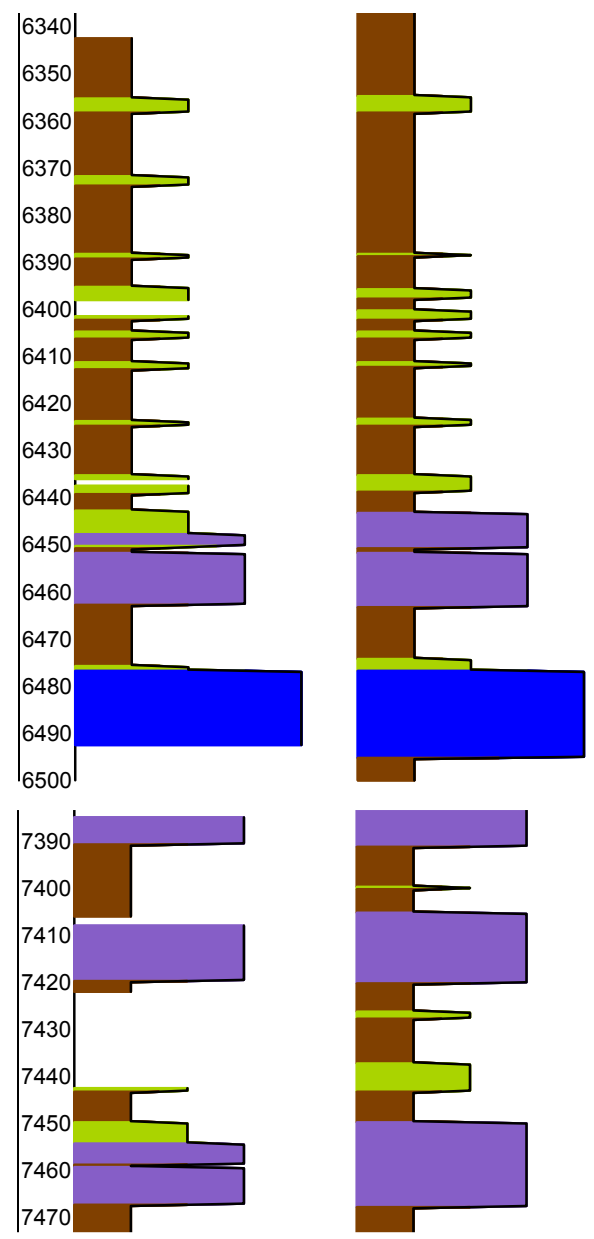

NBU 21

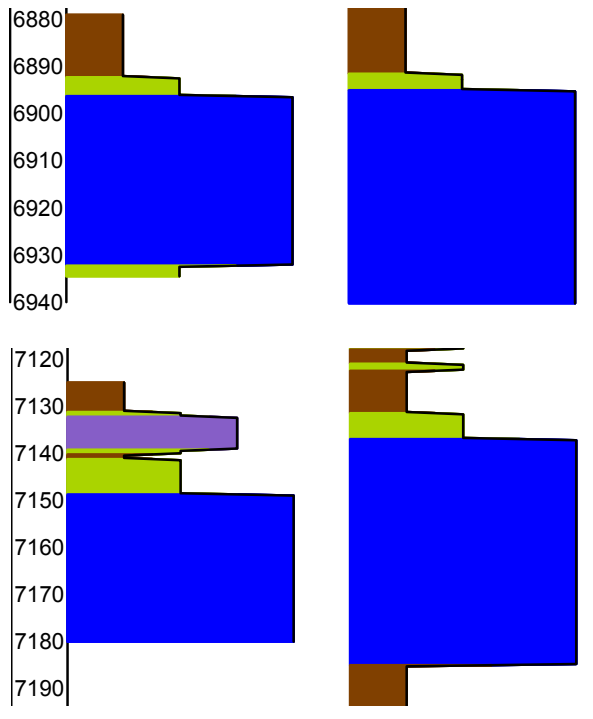

Federal 2-7

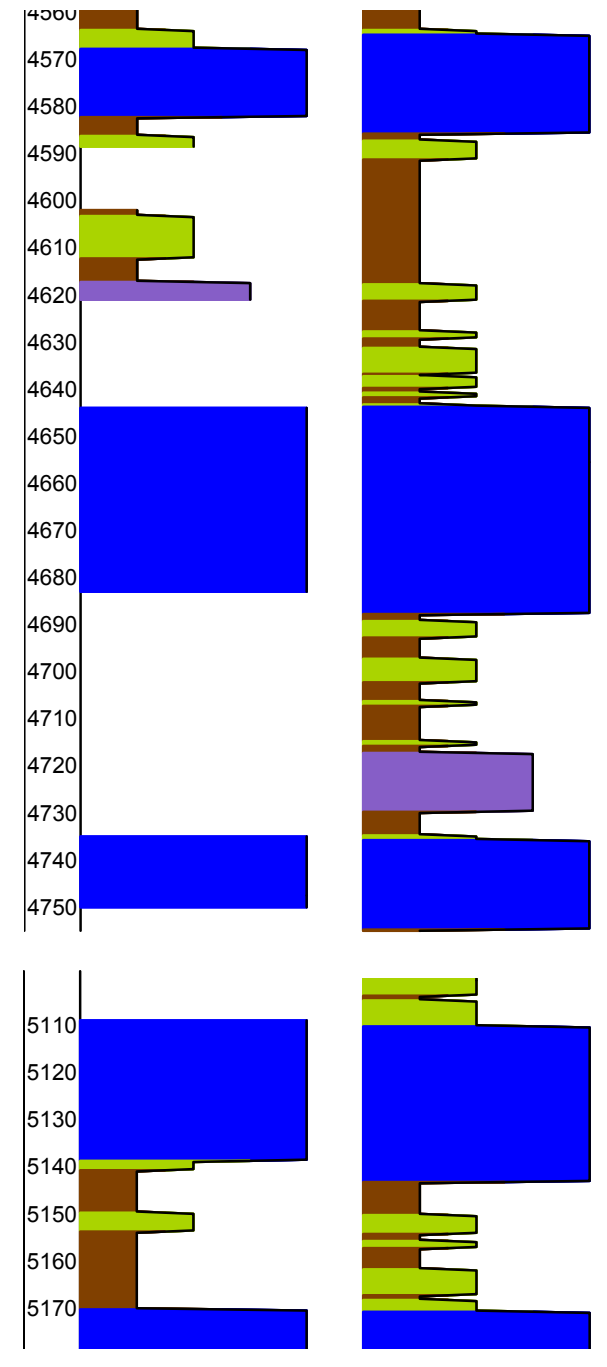

PA 424-34

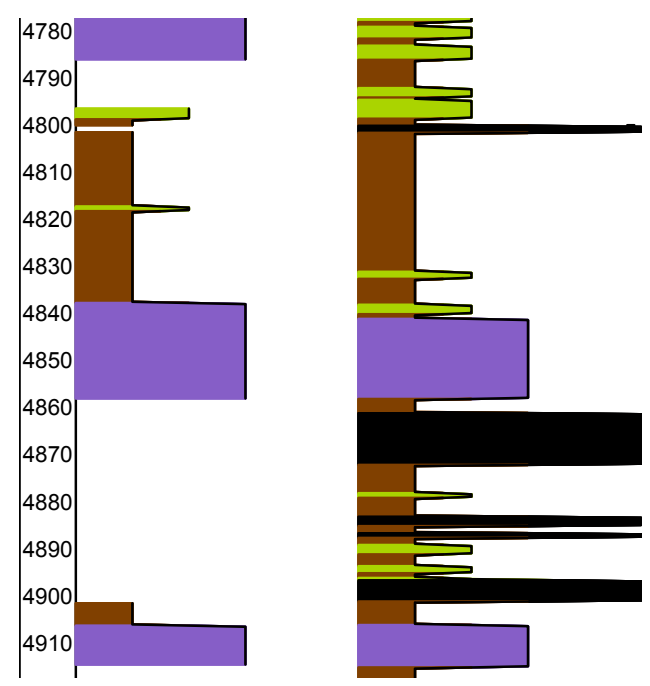

Orchard 16-12 
Architectural Elements

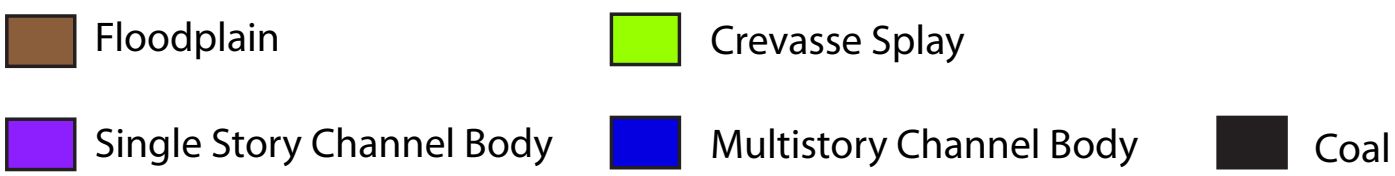

Figure 14: The figure features the testing wells with the architectural elements as classified from core description in the left hand track in .las format. These are compared to the architectural elements as predicted through the combined approach of integrating select classifier results with outcrop-based architectural-element thickness criteria seen in the right hand track in .las format. 
channel body class was found to be highly confused with the crevasse splay class by both classifiers, and combining the two classes would have likely also led to improved measures of inter-class confusion. However, these architectural elements were kept as discrete classes due to their unique depositional and reservoir characteristics which would carry significance if the methods used in this study were to be applied in future mapping and modeling endeavors.

Comparing the Classifiers as Trained by the Different Well-Log-Curve Assemblages

Evaluation of the effectiveness of the two classifiers as trained by the different well-logcurve assemblages was reserved for their ability to predict the four-class architectural element realization given that the measures of accuracy would be more meaningful for this more geologically realistic realization as compared to the five-class architectural-element realization. In both the k-NN and PCP classifiers, the seven different well-log-curve assemblages tested resulted in a small range of overall accuracies achieved by both classifiers with the log curve combination of GR and RHOB being primarily responsible for modestly higher overall accuracies achieved (Figure 15). To avoid the pitfall of making inferences of the effectiveness of the well-log-curve assemblages based only on the overall accuracy metric, which can potentially be misleading if a large testing group is very well predicted (e.g. the floodplain or multi-story channel body testing groups), user's accuracy of the individual architectural elements must also be inspected. Any differences in the user's accuracies of the individual architectural elements produced by the different well-log-curve assemblages in the k-NN classifier are negligible; they are just slightly more accurate when trained by the well-log-curve assemblage GR, RHOB as suggested by the over accuracy metric (Appendix J). The agreement between the overall accuracy and user's accuracy metrics produced by the different well-log-curve assemblages suggests that the log-curve assemblage does not make an immense difference, but is slightly 


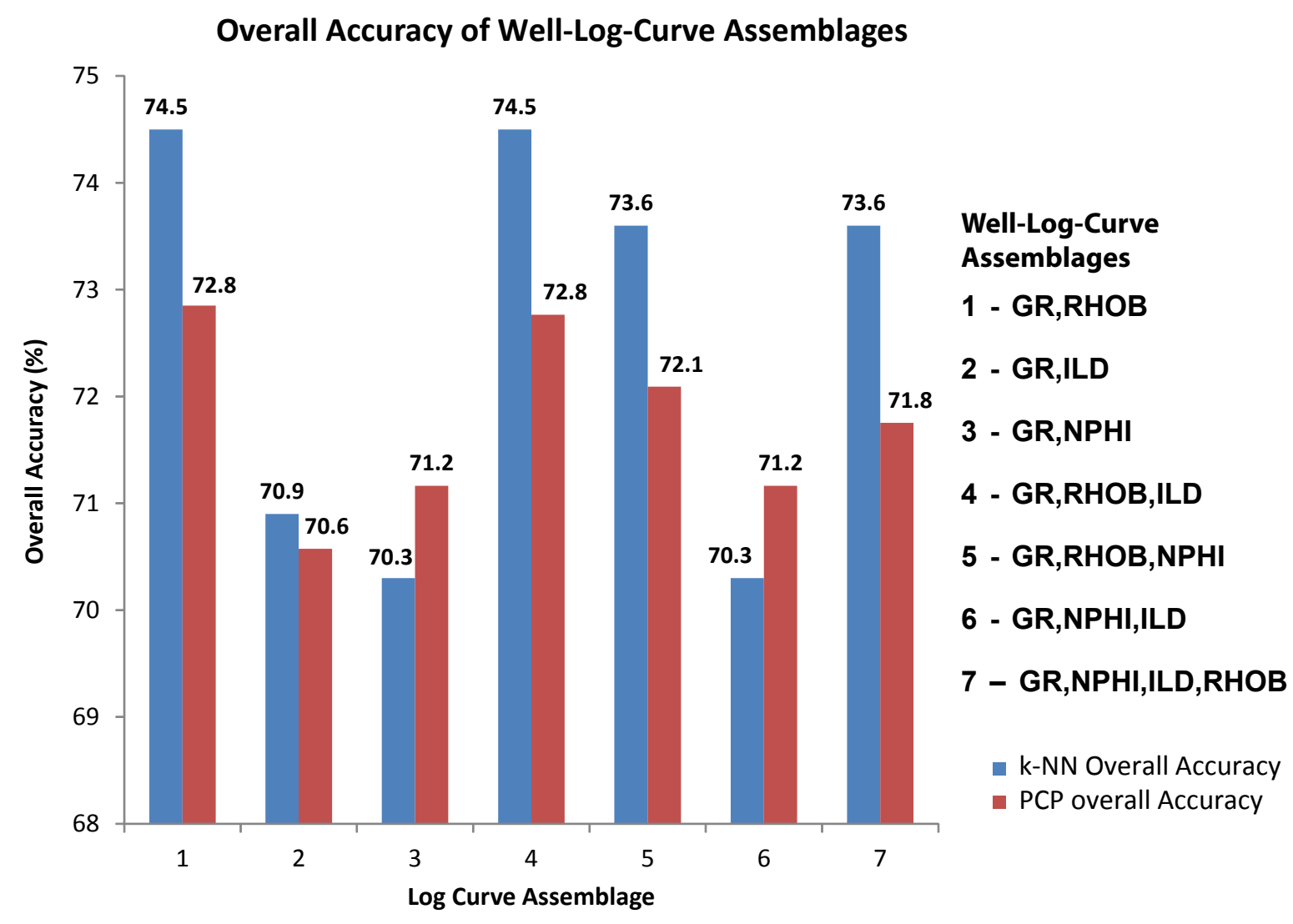

Figure 15: A chart featuring the highest overall accuracies achieved by the two classification methods. Though the range in accuracies achieved by both classifiers is modest, the well-log combinations of GR, RHOB GR, RHOB, ILD produced the highest overall accuracies when used in the training of both classifiers. The addition of ILD to GR, RHOB appears to have little to no affect on the overall accuracy or user's accuracy (Appendices J and M). 
more accurate with the combination of GR and RHOB. This is a beneficial revelation for possible future application of this method in the fluvial deposits of the Mesaverde Group where well-log-curve suites can vary substantially. When user's accuracy was evaluated in the outcomes of the PCP classifier, it was found that the well-log-curve assemblages which included the RHOB well-log curve were roughly $20 \%$ more effective at predicting the crevasse splay class than those that did not contain RHOB (Appendix O). The $\sim 20 \%$ swing observed in the user's accuracy of the crevasse splay class while the overall accuracy concurrently responds to a much lesser degree, highlights the potential for disparity between the two metrics and the need for the simultaneous evaluation of both. A study in the nearby Mamm Creek Field, Piceance Basin, Colorado also emphasized GR and RHOB as the most important well-log-curve assemblage in a method devised to predict diagenetic facies in a single well experiment in the upper part of the Mesaverde Group (Ozkan, 2011). The authors speculated that aside from diagenetic facies, the method may also be useful in predicting the crevasse splay architectural element through its recognition of fine-grained and sometimes clay-matrix-rich siltstones and sandstones (Ozkan, 2011).

As a whole, the k-NN classifier was observed to have a slight advantage over the PCP classifier in that the top overall accuracy for each well-log-curve assemblage was in most cases higher than the overall accuracy produced by the same well-log-curve assemblage in the PCP classifier (Figure 15). The k-NN classifier also did not show the same RHOB well-log curve dependent contrast in its ability to predict the crevasse splay class as was observed in the PCP classifier. The comparative strength of the k-NN classifier to other commonly used classifiers was also noted in a study by Dubois, et al., (2006). 
The Troublesome Single-Story Channel Body Architectural-Element Class

The main source of inter-class confusion in the four-class architectural element realization seen in both classifiers was due to the consistent misclassification of the single-story channel body architectural element class. In the k-NN classifier it was observed that the troubled class was better (though still poorly) predicted at the low k values, and its accuracy became progressively poorer with each successive increase in $\mathrm{k}$ (Appendix $\mathrm{J}$ ). A commonly recognized fault in the k-NN algorithm is that if the k value used is too large, the classes with larger training populations have the potential to overwhelm classes with smaller training populations (Drummond, et al., 2010) (Appendix C). To inspect if the relatively smaller training population of the single-story channel body class was having a negative impact on the success of its prediction, a test was conducted where-in the training populations of the different classes were equalized, thus taking away the potential for class size influence. This resulted in a very slight increase in user's accuracy values (less than 6\% improvement over the previous top user's accuracy) for the single-story channel body (Appendix R). This minimal improvement indicates that if there were a training population sample size influence it was likely insignificant. Equalization of the training populations was also found to be unbeneficial to the success of lithofacies prediction using the k-NN classifier in a study by Dubois, et al., (2006). Examination of fifty random training samples each of the crevasse splay and single-story channel body classes crossplotted against the useful well-log curves of GR and RHOB, illustrates the degree of similarity between the two classes and helps explain the why the potential existed for such confusion (Appendix S). Crossplotting of training samples of the single-story channel body class and the multi-story channel class also illustrates the potential for confusion amongst these classes (Appendix S). 
Because diagenetic and mineral composition vary both geographically and stratgraphically in the fluvial deposits of the Mesaverde Group (Keighin and Fouch, 1981; Johnson and Roberts, 2003; Stroker et al., 2012), without conducting detailed petrographic work it is only possible to broadly speculate on geologic drivers for the single-story channel body inter-class confusion. It was observed in core that single-story channel bodies could range from upper very fine to medium sand grain size. This range in grain size overlaps to some degree with both the crevasse splay grain sizes (silt to fine sand) and the multi-story channel body grain sizes (upper fine to medium upper sand). All three of these architectural elements also contain the ripple laminated sandstone lithofacies to varying extents. These common characteristics are also recorded in outcrop descriptions of Mesaverde Group fluvial architectural-elements by Cole and Cumella, (2005); White, et al., (2008); Harper, (2011); Hlava, (2008); Keeton, (2012). Perhaps these overlapping attributes of grain size and lithofacies contribute to the frequent misclassification of the single-story channel body.

Incorporation of Thickness Criteria and Geologically Constrained Electrofacies Prediction

The resulting improvement in single-story channel body prediction through the incorporation of thickness criteria with classifier outcomes via the thickness criteria approach makes the methods described in this study a much more viable means of predicting the fluvial architectural elements of the Mesaverde Group in non-cored wells. An unfortunate byproduct of the thickness criteria approach was the moderate (16\%) decrease in user's accuracy experienced by the crevasse splay class. This is a consequence of the merging of the crevasse splay and single-story channel body classes prior to running the single-story channel body thickness criteria code described in the methods which resulted in crevasse splays that directly overlie or 
underlie a single-story channel body being grouped with the contiguous single-story channel body. This side-effect should be kept in mind during future application of this process.

There is no limit to how the thickness criteria of this program can be manipulated in order to tailor the thickness criteria approach to a particular study. As an example, it may be desirable to attempt the prediction and mapping of the large amalgamated channel bodies, deemed "super stories" by some, which are proposed to represent deposition in incised valleys (White, et al., 2008; Mike Uland, personal communication, 2013). However, it should be cautioned that there is always the potential for the well in which the architectural elements are being predicted to have penetrated a large sandstone body at its comparatively thinner margin which may result in its misclassification as an isolated single-story channel body.

To demonstrate the application of the methods described in this paper, the results of the k-NN classifier trained by the well logs GR and RHOB and a k value of 20 , which produced the highest overall accuracy of all uniquely trained classifiers $(74.5 \%)$, were paired with the thickness criteria approach to predict the fluvial architectural elements of the four-class realization in the Mesaverde Group fluvial interval of non-cored wells (N=216) throughout the study area. Mapping of the cumulative thickness of the single-story channel body architectural element revealed an area of relatively high cumulative thickness in the northwestern portion of the study area (Figure 16). This thickening corresponds to the area in and around Natural Buttes Field, Utah in which highly discontinuous, lenticular sandstone bodies have been recognized as the primary Mesaverde Group reservoirs (Schmoker et al., 1996; Stancel et al., 2008). When cumulative thickness values of the multi-story channel body class were mapped, a roughly eastto-west trend was noted in the southern portion of the Piceance Basin, Colorado (Figure 16). The extent of well control prevents investigation in this southernmost portion, however it is 
Cumulative Thickness ( $\mathrm{ft}$ )

Single-story Channel Body
Cumulative Thickness (ft)

Multi-story Channel Body
Net Thickness (ft)
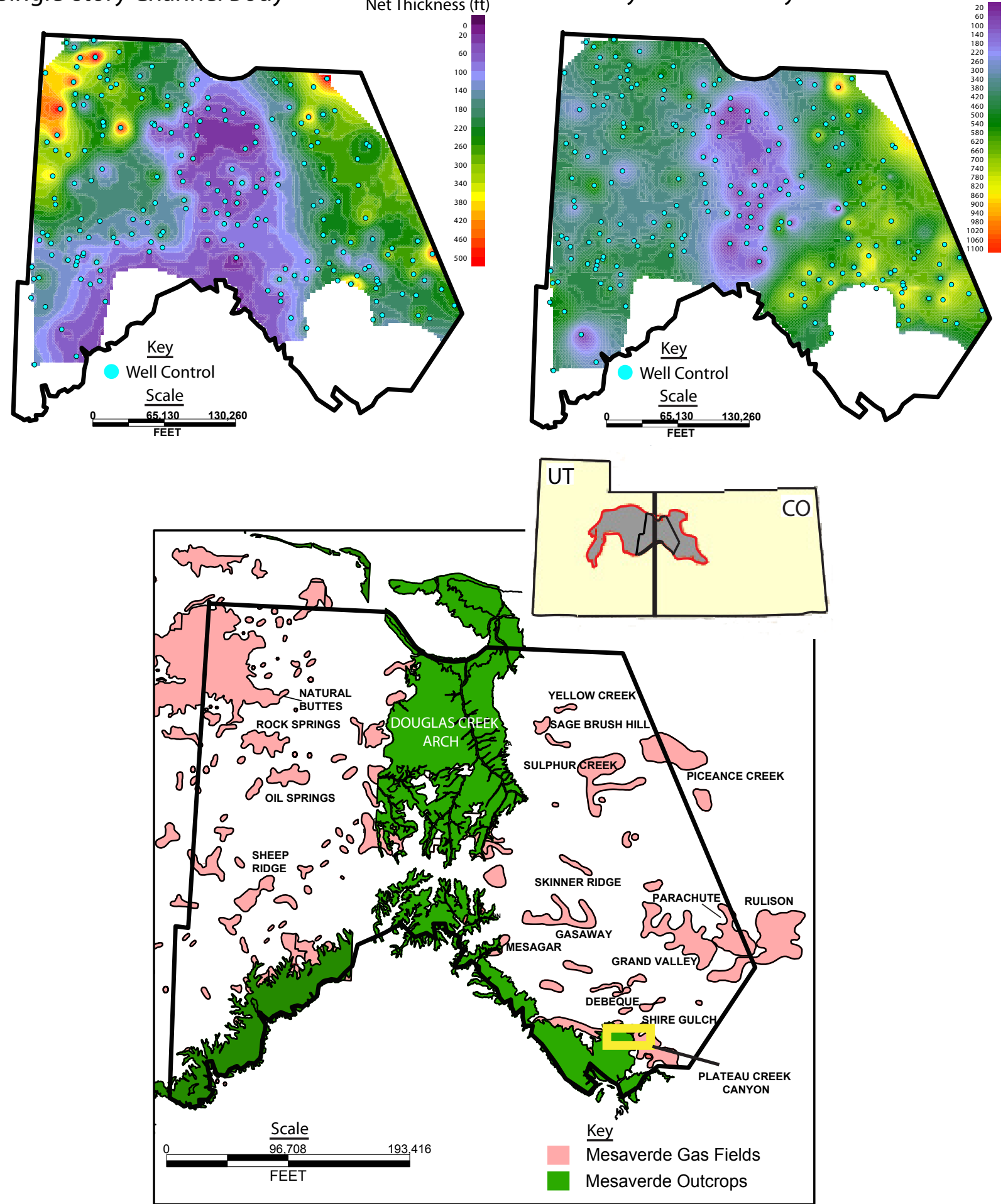

Figure 16: The top two maps display cumulative thicknesses of the channel body architectural elements. A map of Mesaverde Group gas fields and outcrops in the study area is featured at the bottom. In yellow is the location of Plateau Creek Canyon, Colorado, the western extent of the amalgamated channel bodies that continue east to Parachute Field, Colorado. 
noted in outcrop and well-logs that large amalgamated channel bodies are continuous from Plateau Creek Canyon, Colorado to Parachute Field, Colorado (Foster, 2010) (Figure 16). Perhaps the relative increase in cumulative thickness for the multi-story channel body class observed in the generated maps is related to this nearby occurrence of large amalgamated channel bodies. The cumulative thicknesses of both the single-story and multi-story channel bodies are observed to follow general Mesaverde Group thickness trends where they decrease at the Douglas Creek Arch, Colorado and thicken towards the center of the Piceance Basin, Colorado (Hettinger and Kirschbaum, 2002).

\section{Conclusions}

While previous studies of the fluvial deposits of the upper Mesaverde Group have historically relied on the analysis of core samples, outcrops, or the manual interpretation of well logs to develop architectural-element classifications, this study explors an alternative approach through the use of statistical classification methods. Through the combination of selected classifier results with outcrop-based, architectural element thickness criteria, an overall accuracy of $83.6 \%$ was achieved for the simplified four-class architectural-element realization. The individual architectural elements were predicted with user's accuracies of $0.891,0.376,0.735$, and 0.985 for the floodplain, crevasse splay, single-story channel body, and multi-story channel body classes, respectively. Combining the thickness criteria approach with the selected classifier results, resulted in a vast improvement in the prediction of the single-story channel-body architectural-element class which both the k-NN and PCP methods on their own were unable to distinguish as a distinct electrofacies class.

Significant changes in prediction performance were not elicited by the classifiers as trained by the seven different well-log-curve assemblages with the exception that the PCP 
classifier predicted the crevasse splay class more competently when the RHOB well-log curve was utilized. Though the disparity was modest, the use of well-log curves GR and RHOB was associated the highest overall accuracies achieved by both the k-NN and PCP classifiers. The common occurrence of these well-log curves in the study area bodes well for future use of the studied classification techniques. Unique to the k-NN classifier, the potential for improved prediction performance based on choice of $\mathrm{k}$ value was also demonstrated, highlighting the benefits of experimenting with this variable. As a whole, the k-NN classifier showed a small but consistent advantage over the PCP classifier in terms of prediction performance.

When coupled with the outcrop-based thickness criteria approach, the methods described in this study present a feasible approach to the classification of the fluvial architectural elements of the upper part of the Mesaverde Group in the Piceance and Uinta basins in well logs. This has implications for future work which could allow for the creation of maps and the population of 3D geologic models to be carried out in a timely fashion with results that are objective and easily reproducible. 


\section{References}

Beaudoin, A., L. Guindon; A. Leboeuf; J.E. Luther; C.H. Ung, S. Cote, M.C. Lambert, 2005, Biomass mapping of northern boreal forests using a k-nn approach and sample plots from high resolution QuickBird images, Symposium on Remote Sensing, 14-16 June, 2005, paper no. 74 .

Bremner, D., E. Demaine, J. Erickson, J. Iacono, S. Langerman, P. Morin, G. Toussaint, 2005, Output sensitive algorithms for computing nearest neighbor decision boundaries. Discrete Comput Geometry 33(4), pp. 593-604.

Bridge, J.S., and R. S. Tye, 2000, Interpreting the dimensions of ancient fluvial channel bars, channels, and channel belts from wireline-logs and cores: AAPG Bulletin, v. 84, no. 8, p. 1205-1228.

Bridge, J.S., 2006, Fluvial facies models: Recent developments, in H.W. Posamentier, and R.G. Walker, (eds.): Facies Models Revisited: SEPM Special Publication 84, no. 86, p. 85-170.

Busch, J.M., Fortney, W.G., Berry, L.N., 1987. Determination of lithology from well logs by statistical analysis. Society of Petroleum Engineers Formation Evaluation 2, 412-418.

Cole, R. D., and S. P. Cumella, 2003, Stratigraphic architecture and reservoir characteristics of the Mesaverde Group, southern Piceance Basin, Colorado, in K. M. Peterson,T. M. Olson, and D. S. Anderson, eds., Piceance Basin 2003 Guidebook: Denver, Colorado, Rocky MountainAssociation of Geologists, p. 385-442.

Cole, R. and S. Cumella, 2005, Sand-body architecture in the lower Williams Fork Formation (Upper Cretaceous), Coal Canyon, Colorado, with comparison to the Piceance Basin subsurface: The Mountain Geologist, v. 42, no. 3, pp. 85-108.

Cole, R., 2008, Characterization of Fluvial Sand Bodies in the Neslen and lower Farrer Formations (Upper Cretaceous), Lower Sego Canyon, Utah. In: M.W. Longman and C.D. Morgan, (eds.), Hydrocarbon Systems and Production in the Uinta Basin, Utah, Rocky Mountain Association of Geologists and Utah Geological Association Publication 37, p. 83.

Congalton, R.G., 1991, A review of assessing the accuracy of classifications of remotely sensed data. Remote Sensing of Environment, vol. 37, pp. 35-46.

Cover, T.M., P.E. Hart, 1967, Nearest neighbor pattern classification, IEEE Transactions on Information Theory, vol. 13 issue 1, pp. $21-27$.

Delfiner, P., Peyret, O., Serra, O., 1987. Automatic determination of lithology from well logs. Society of Petroleum Engineers Formation Evaluation 2, 303-310.

Doveton, J.H., and S.E. Prensky, 1992, Geological applications of wireline logs: a synopsis of development and trends, The Log Analyst, v. 33, no. 3, pp. 286-303. 
Doveton, J.H., 1994, Geologic log analysis using computer methods, AAPG Computer Applications in Geology, no. 2, AAPG, Tulsa, Oklahoma, pp. 1-169.

Drummond, R.D., A.C. Vidal, J.F. Bueno, E.P. Leite, 2010, Maximum autocorrelation factors applied to electrofacies classification, 2010 SEG Annual Meeting, October 17 - 22, 2010, Denver, Colorado, pp. $1560-1563$.

Dubois, M.K., G.C. Bohling, S. Chakrabarti, 2006, Comparison of four approaches to a rock facies classification problem, Computers and Geoscience, 33, pp. 599-617.

Ellison, A. I., 2004, Numerical modeling of heterogeneity within a fluvial point-bar deposit using outcrop and lidar data: Williams Fork Formation, Piceance Basin, Colorado: M.S. thesis, University of Colorado, Boulder, CO, p. 234

Eslinger, E., F. Boyle, 2011, Mineral and well log balance for computing porosity in argillaceous rocks - applications in gas shales, paper presented at the International Unconventional OilGas Conference at the China University of Petreoleum, Qinqdao, China, July 4-5, 2011, pp. $1-31$.

Eslinger, E., R.V. Everett, 2012, Petrophysics in gas shales, AAPG Memoir 97, p. $419-451$.

Flaig, Peter P., McCarthy, P.J., and Fiorillo, A.R., 2011, A Tidally-Influenced, High-Latitude Coastal Plain: The Late Cretaceous (Maastrichtian) Prince Creek Formation, North Slope, Alaska in Davidson, S., Leleu, S., and North, C. eds., From River to Rock Record: The Preservation of Fluvial Sediments and their Subsequent Interpretation, SEPM Special Publication 97, p. 233-264.

Foody, G.M., 2002, Status of land cover classification accuracy assessment, Remote Sensing of Environment, vol. 80, p. 187.

Foster, R., 2010, Sequence stratigraphy of the Upper Cretaceous Middle Williams Fork Formation, Piceance Basin, northwestern Colorado: Implications for reservoir sandstones, Master's of Science, University of Colorado Boulder, Boulder, p. 78.

German, Q.A., 2006, Analysis of fluvial sandstone-body characteristics and architecture in a high net-to-gross system: upper Williams Fork Formation, Plateau Creek Canyon, Piceance Basin, Colorado, Master's of Science, University of Colorado Boulder, Boulder, pp. 1-42.

Grotsch, J., Mercadier, C., 1999. Integrated 3-D reservoir modeling based on 3-D seismic: the Tertiary Malampaya and Camago buildups, offshore Palawan, Philippines. American Association of Petroleum Geologists Bulletin 83 (11), 1703-1728.

Haapanen, R., A.R. Ek, M.E. Bauer, A.O. Finley, 2004, Delineation of forest/nonforest land use classes using nearest neighbor methods, Remote Sensing of Environment, 89, pp. 265-271. 
Hall, P., B.U. Park, R.J. Samworth, 2008, Choice of neighbor order in nearest-neighbor classification, The Annals of Statistics, Vol. 36, No. 5, p. 2.

Hamilton, D. S., and W. E. Galloway, 1989, New exploration techniques in the analysis of diagenetically complex reservoir sandstones, Sydney basin, N.S.W., Australia: Australian Petroleum Exploration Association Journal, v. 29, part 1, p. 235-257.

Harper, E.S, 2011, Fluvial architecture of the lower Williams Fork Formation, (middle Mesaverde Group), Douglas Creek Arch, Colorado, Master's of Science, University of Colorado Boulder, Boulder, pp. 30-46.

Hemborg, H. T., 2000, Gas production characteristics of the Rulison, Grand Valley, Mamm Creek, and Parachute fields, Garfield County, Colorado, turning marginally economic basincentered tight-gas sands into profitable reservoirs in the southern Piceance Basin: Colorado Geological Survey Resource Series 39, p. 1-30.

Hettinger, R.D., and Kirschbaum, M.A., 2002, Stratigraphy of the upper Cretaceous Mancos Shale (upper part) and Mesaverde Group in the southern part of the Uinta and Piceance basins, Utah and Colorado, U.S. Geological Survey Investigation Series I 2764, pp. 15-17.

Hettinger, R D; Kirschbaum, Mark A, 2003, Stratigraphy of the Upper Cretaceous Mancos Shale (upper part) and Mesaverde Group in the southern part of the Uinta and Piceance basins, Utah and Colorado: U. S. Geological Survey Digital Data Series, DDS-0069-B, p. 21.

Hewlett, A.C., 2010, Fluvial architecture and static connectivity of the Williams Fork Formation, central Mamm Creek Field, Piceance Basin, Colorado: Master's of Science, University of Colorado Boulder, Boulder, p. 44.

Hlava, K.S., 2008, Sequence-stratigraphic controls on reservoir-scale architecture of the middle Mesaverde Group, Douglas Creek Arch, Colorado, Master's of Science, University of Colorado Boulder, Boulder, p. 21.

Janssen, L.F., F.M. van der Wel, 1994, Accuracy assessment of satellite derived land-cover data: a review. Photogrammetric Engineering and Remote Sensing, vol. 60, 419-426.

Johnson, R.C., and T.M. Finn, 1986, Cretaceous through Holocene history of the Douglas Creek Arch, Colorado and Utah, in Stone, D.S., ed., New interpretations of northwest Colorado geology: Rocky Mountain Association of Geologists Guidebook, pp. 77-95.

Johnson, R. C., 1989. Geologic history and hydrocarbon potential of Late Cretaceous age, lowpermeability reservoirs, Piceance Basin western Colorado: U. S. Geological Survey Bulletin 1787-E, p. 51. 
Johnson, R.C., 1990, Development of Laramide-style subsidence trends during Late Cretaceous foreland basin deposition, northwest Colorado [abs.]: American Association of Petroleum Geologists Bulletin, v. 74, no. 5, p. 687.

Johnson, R.C., and S.B. Roberts, 2003, The Mesaverde total petroleum system, Uinta-Piceance, Utah and Colorado, Chapter 7, U.S. Geological Survey Digital Data Series DDS-69-B, Version 1.0, p. 12, [CD-ROM].

Kapur, L., Lake, L., Sepehrnoori, D., Herrick, D. Kalkomey, C., 1998. Facies prediction from core and log data using artificial neural network technology. In: Transactions of the 39th Society of Professional Well Log Analysts Annual Logging Symposium, Keystone, CO, paper PP, p. 11.

Keeton, G.I., 2012, Sedimentological and stratigraphic characteristics of fluvial sandstones based on outcrop spectral-gamma-ray data and borehole images, Williams Fork Formation, Piceance Basin, Colorado, Master's of Science, University of Colorado Boulder, Boulder, pp. 61-63.

Keighin, C.W., and Fouch T.D., 1981, Depositional environments and diagenesis of some nonmarine Upper Cretaceous rocks, Uinta Basin, Utah, in Ethridge, F.G., and Flores, R.M., eds, Recent and ancient non-marine depositional environments; models for exploration: Soceity of Economic Paleontologists and Mineralogists Special Publication 31, pp. 109-125.

Kohavi, R., F. Provost, 1998, Special issue on applications of machine learning and the knowledge discovery process: Boston, Kluwer Academic Publishers, p. 271.

Lawton, T.F., 1983, Tectonic and sedimentologic evolution of the Utah foreland basin; Ph.D. thesis, University of Arizona, Tuscon, p. 217.

Lawton, T.F., 1986, Fluvial systems of the Upper Cretaceous Mesaverde Group and North Horn Formation, central Utah-A record of transition from thin-skinned to thick-skinned deformation in the foreland region, in Peterson, J.A., ed., Paleotectonics and sedimentation in the Rocky Mountain region, United States: American Association of Petroleum Geologists Memoir 41, p. 423-442.

Leibovitz, M.B., 2010, Sequence stratigraphy of the Upper Cretaceous Williams Fork Formation, Piceance Basin, northwest Colorado, and its contribution to the basin-centered gas accumulation: Master's of Science, University of Colorado Boulder, Boulder, p. 41.

Lorenz, J.C., and A.K. Rutledge, 1987, Late Cretaceous Mesaverde Group outcrops at Rifle Gap, Piceance Creek Basin, northwestern Colorado, in, Beus, S.S. (ed.): Rocky Mountain Section Geological Society of America, Centennial Field Guide, v. 2, pp. 307-310. 
Lorenz, J.C. and G.C. Nandon, 2002, Braided river deposits in a muddy depositional setting: the Molina Member of the Wasatch Formation (Paleogene), west-central, Colorado, U.S.A.: Journal of Sedimentary Research, v. 72, no. 3, pp. 376-385.

McRoberts, R.E., M.D. Nelson; D. Wendt, 2002, Stratified estimates of forest area using satellite imagery, inventory data, and the k-nearest neighbor technique, Remote Sensing of the Environment, vol. 82, pp. 457-468.

Miall, A.D., 1978, Lithofacies types and vertical profile models in braided river deposits: a summary, in: A.D. Miall (ed.): Fluvial Sedimentology, Can. Soc. Petrol. Geol. Mem., 5, pp. 596-604.

Miall, A.D., 1985, Architectural-element analysis: a new method of facies analysis applied to fluvial deposits, Earth-Science Reviews, 22, pp.261-308.

Miall, A.D., 2010, Alluvial deposits. In: James, N.P., and Dalrymple, R.W., (ed.): Facies Models 4, Geological Association of Canada, St. John's, Newfoundland, $4^{\text {th }}$ edition, pp. 105-137.

Ozkan, A., S.P. Cumella, K.L. Milliken, S.E. Laubach, 2011, Prediction of lithofacies and reservoir quality using well logs, Late Cretaceous Williams Fork Formation, Mamm Creek field, Piceance Basin, Colorado, AAPG Bulletin, V. 95, No. 10, pp. 1699-1723.

Panjaitan, H., 2006, Sand-body dimensions in outcrop and subsurface, lower Williams Fork Formation, Piceance Basin, Colorado, Master's of Science, Colorado School of Mines, Golden Colorado, pp. 21-79.

Patterson, P.E., K. Kronmueller, and T.D. Davies, 2003, Sequence stratigraphy of the Mesaverde Group and Ohio Creek Conglomerate, northern Piceance Basin, Colorado, in K.M. Peterson, T.M. Olsen, and D.S. Anderson, eds., Piceance Basin 2003 Guidebook: Rocky Mountain Association of Geologists, pp. 115-129.

Pranter, M. J., A. I. Ellison, R. D. Cole, and P. E. Patterson, 2007, Analys is and modeling of intermediate-scale reservoir heterogeneity based on a fluvial point-bar outcrop analog, Williams Fork Formation, Piceance Basin, Colorado: AAPG Bulletin, v. 81, no. 7, p. 1025-1051.

Pranter, M. J., R. D. Cole, *H. Panjaitan, *N. K. Sommer, 2009, Sandstone-body dimensions in a lower coastal-plain depositional setting: lower Williams Fork Formation, Coal Canyon, Piceance Basin, Colorado, U.S.A., AAPG Bulletin, vol. 93, p. 1379-1401.

Pranter, M. J. and N. K. Sommer, 2011, Static connectivity of fluvial sandstones in a lower coastal-plain setting: An example from the Upper Cretaceous lower Williams Fork Formation, Piceance Basin, Colorado, AAPG Bulletin, vol. 95, pp. 899-923.

Patterson, P.E., K. Kronmueller, and T. D. Davies, 2003, Sequence stratigraphy of the Mesaverde Group and Ohio Creek conglomerate, northern Piceance Basin, Colorado, 
in K. M. Peterson, T. M. Olson, and D. S. Anderson, eds., Piceance Basin 2003 Guidebook: Denver, Colorado, Rocky Mountain Association of Geologists, p. 115-129

Pranter, M. J. and N. K. Sommer, 2011, Static connectivity of fluvial sandstones in a lower coastal-plain setting: An example from the Upper Cretaceous lower Williams Fork Formation, Piceance Basin, Colorado, AAPG Bulletin, vol. 95, pp. 899-923.

Retallack, G.J. 2001. Soils of the Past: an Introduction to Paleopedology. Second Edition, Blackwell, Oxford.

Rider, M. 2002, Facies, sequences and depositional environments from logs (Chapter 14), in M. H. Rider, ed., The Geological Interpretation of Well Logs, 2nd edition: Rider-French Consulting Ltd., p. 226- 238.

Rider, M., and Laurier, D., 1979, Sedimentology using a computer treatment of well logs, Trans. Soc. of Well Log Analysts, $6^{\text {th }}$ European Symposium, London, Paper J.

Russell, S.D., Abkar, M., Vissapragada, B., Walkden, G.M., 2002. Rock types and permeability prediction from dipmeter and image logs: Shuaiba reservoir (Aptian), Abu Dhabi. American Association of Petroleum Geologists Bulletin 86 (10), 1709-1732.

Saggaf, M.M., Nebrija, E.L., 2000. Estimation of lithologies anddepositional facies from wireline logs. American Association of Petroleum Geologists Bulletin 84, 1633-1646.

Schmoker, J.W., T.D. Fouch, and R.R. Carpentier, 1996, Gas in the Uintah Basin, Utah resources in continuous accumulations: The Mountain Geologist, v. 33, n. 4, pp. 95-104.

Serra, O. and Sulpice, L., 1975. Sedimentological analysis of shale-sand series from well logs. Transactions of the SPWLA 16th Annual Logging Symposium, paper W.

Serra, O., and Abbott, H.T., 1980, The contribution of logging data to sedimentary sedimentology and stratigraphy, SPE-9270: Society of Petroleum Engineers, presented at 55th Annual Technical Conference and Exhibition [Dallas], preprint, 19 p. Later published in 1982, Society of Petroleum Engineers Journal, v. 22, no. 1, p. 117-131.

Serra, O., 1989, Sedimentary environments from wireline logs. $1^{\text {st }}$ and $2^{\text {nd }}$ eds., Schlumber, M081031 SMP-7008.

Sloan, J.A., 2012, Stratigraphic architecture and connectivity of a low net:gross fluvial system: combining outcrop analogs and multiple-point geostatistical modeling, lower Williams Fork Formation, Piceance Basin, Colorado, Master's of Science, University of Colorado Boulder, Boulder, pp. 29-39.

Shaak, R. V., 2010, Stratigraphic architecture of shallow-marine to coastal-plain parasequences: Lower Williams Fork Formation, southeastern Piceance Basin, Colorado: M.S. thesis, University of Colorado, Boulder, Colorado, pp. 81-120. 
Smith N.D. and J. Rogers, eds. 1999, Fluvial Sedimentology, VI.Spec. Pub. Int. Assoc. Sedimentol. Oxford, UK: Blackwell

Spencer, C.W., 1995, Uinta-Piceance Basin Province (020), in Gautier, D. L., Dolton, G.L., Takahashi, K.I., and Varnes, K.L., (eds)., 1995 National Assessment of United States oil and gas resources--Results, methodology, and supporting data: U.S. Geological Survey Digital Data Series DDS-30, Release 2, p. 1, [CD-ROM].

Stancel, S., J.J. Cuzella, L. MacMillan, A. Ragas, 2008, Controls on Gas Production along the Southern Flank of Greater Natural Buttes Field: A Case Study of the Love Area, Uinta Basin, Utah. In: M.W. Longman and C.D. Morgan, (eds.): Hydrocarbon Systems and Production in the Uinta Basin, Utah, Rocky Mountain Association of Geologists and Utah Geological Association Publication 37, p.237-265.

Stroker, T.M., N.B. Harris, C.W. Elliot, J.M. Wampler, Diagenesis of a tight gas reservoir: Upper Mesaverde Group, Piceance Basin, Colorado, Marine and Petroleum Geology, vol. 40, pp. 48-68.

Sullivan, K.B., J.S. Campbell, and K.E. Dahlberg, 2003, Petrofacies: enhancing the deepwater reservoir characterization effort in West Africa, Petrophysics, vol. 44, no. 3, pp. 177-189.

Ting, K.M., 2011, Confusion matrix, in C. Sammut, and G.I. Webb, Encyclopedia of machine learning, 1st Edition Springer. ISBN 0387307680, p. 209.

White, H., C. Cole, S. Stancel, C. Lee, L. MacMillan, 2008, Window outcrop analogs for Greater Natural Buttes field, Uinta Basin, Utah, in, Hydrocarbon Systems and Production in the Uinta Basin, Utah, M.W. Longman and C.D. Morgan, editors, Rocky Mountain Association of Geologists and Utah Geological Association Publication 37, p. 209-235.

Wolff, M., and J. Pelissier-Combescure, 1982, FACIOLOG- Automatic electrofacies determination, paper FF, in $23^{\text {rd }}$ Annual Logging Symposium Transactions: Society of Professional Well Log Analysts, p. 22.

Vallejo, J.S., 2010, Prediction of lithofacies in thinly bedded Barnett Shale, using probabilistic methods and clustering analys is through GAMLS TM (Geologic Analysis via Maximum Likelihood System), Master's thesis, University of Oklahoma, Norman, Oklahama, p. 63.

Yeung, C.A., N. Gibbins, N. Shadbolt, 2008, A k-nearest-neighbor method for classifying web search results with data folksonomies, In, $2008 \mathrm{IEEE} / \mathrm{WIC} / \mathrm{ACM}$ International Conference on Web Inteligence and Intelligent Agent Technology, Sydney Australia, 09-12 Dec 2008, pp. 70-76. 
Appendix A

Structural Boundaries of the Piceance Uinta Basin Province

The following schematic map features the structural boundaries to the north, south, east and west of the Piceance and Uinta basins of northwestern Colorado and eastern Utah respectively. 


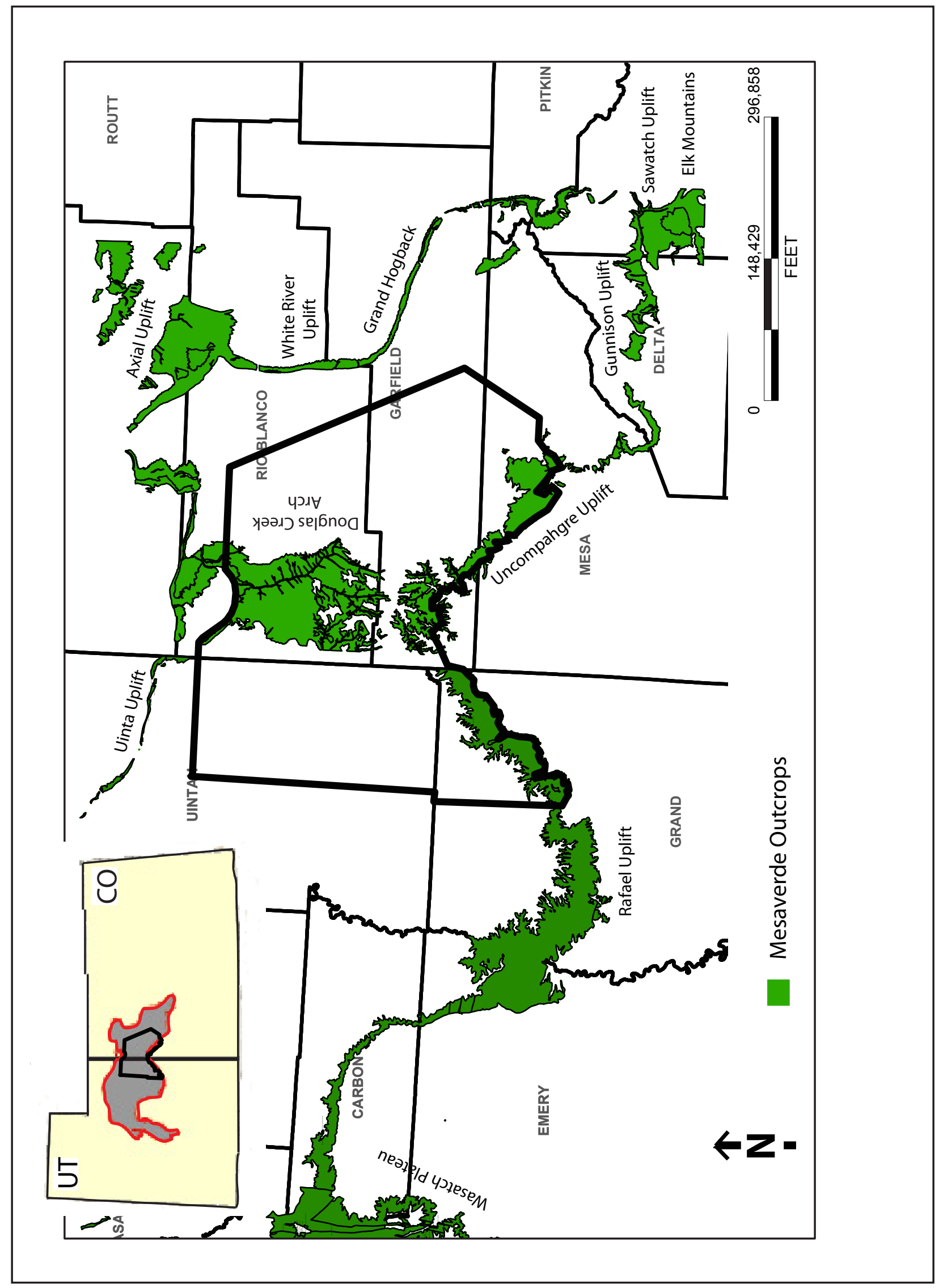


Appendix B

Selecting Training and Testing Samples

The following figure is an example of the selection of sampling points (shown in red lines) that are chosen in logplot, each having a confidently decided architectural-element classification and up to four well-log-curve vales associated with them. 


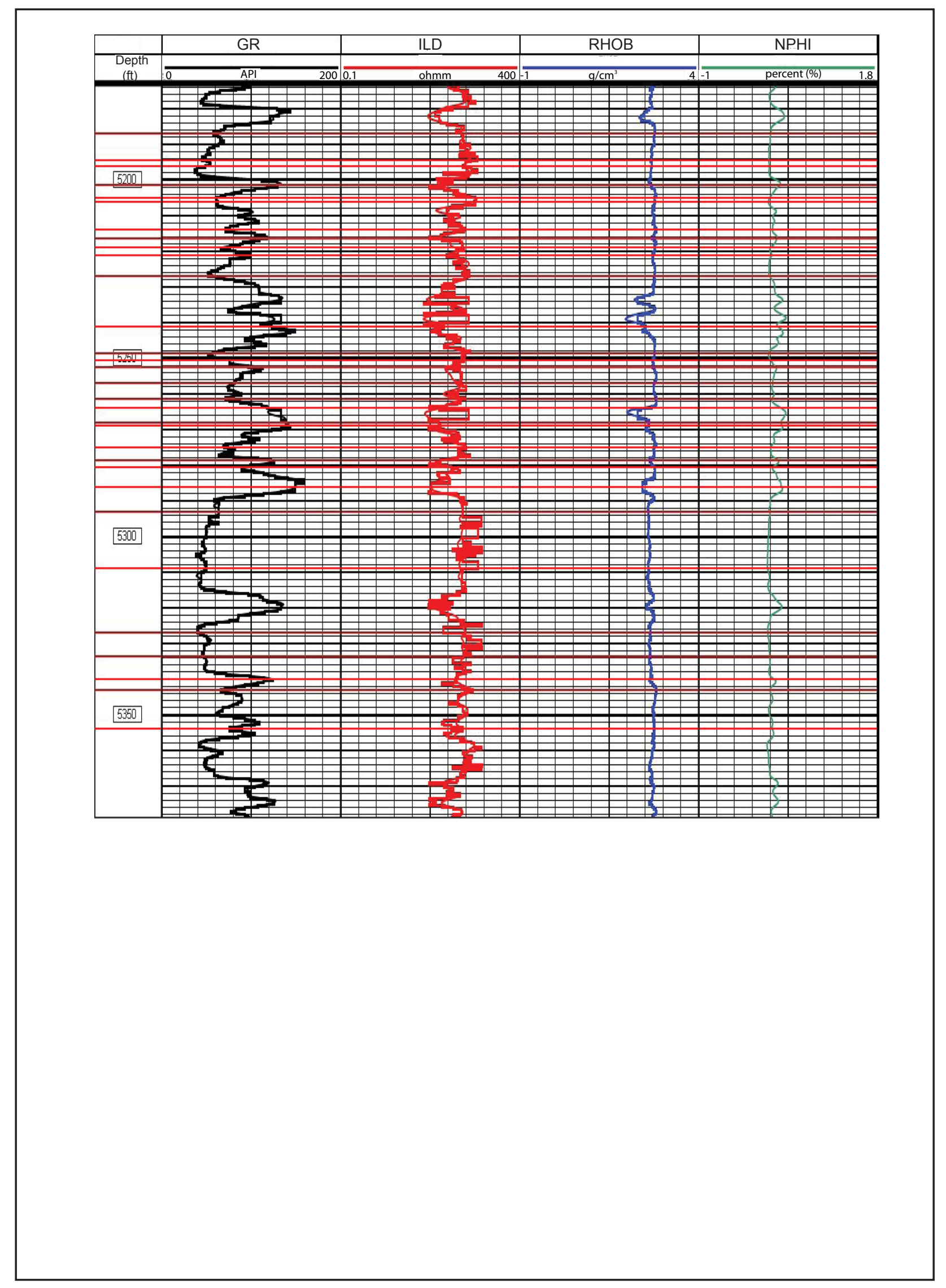




\section{Appendix C}

\section{Distribution of Training and Testing Populations}

The following two pie charts display the distributions of the core depth samples used in the training and testing of classifier models that are associated with a known architecturalelement classification as interpreted from core description. 
Architectural Element Training Population

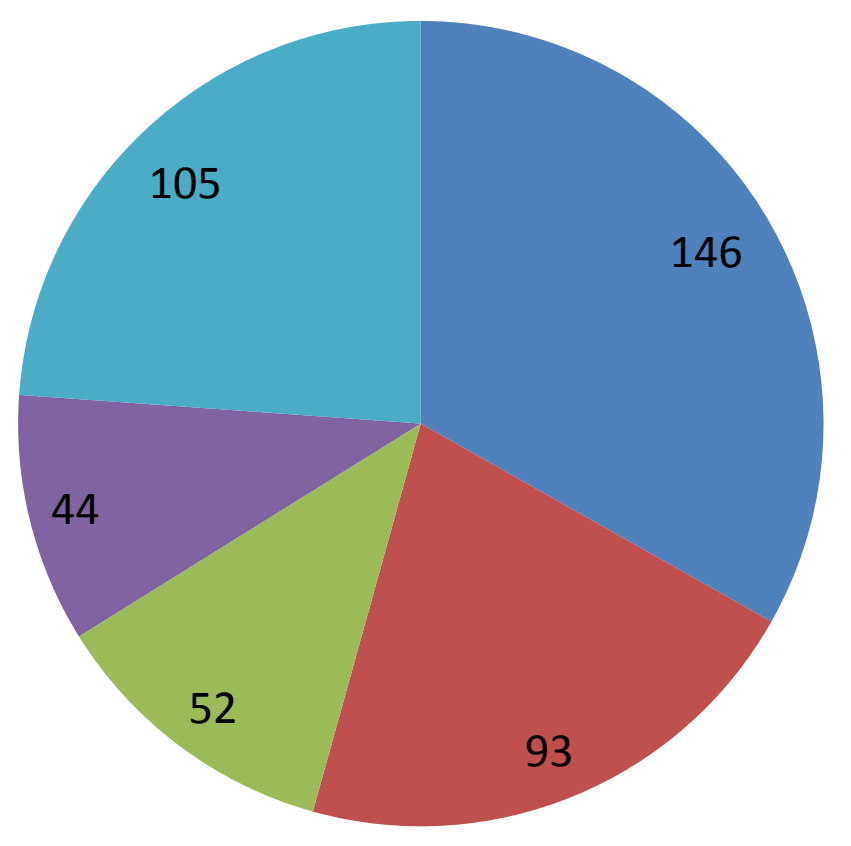

Architectural Element Testing Population

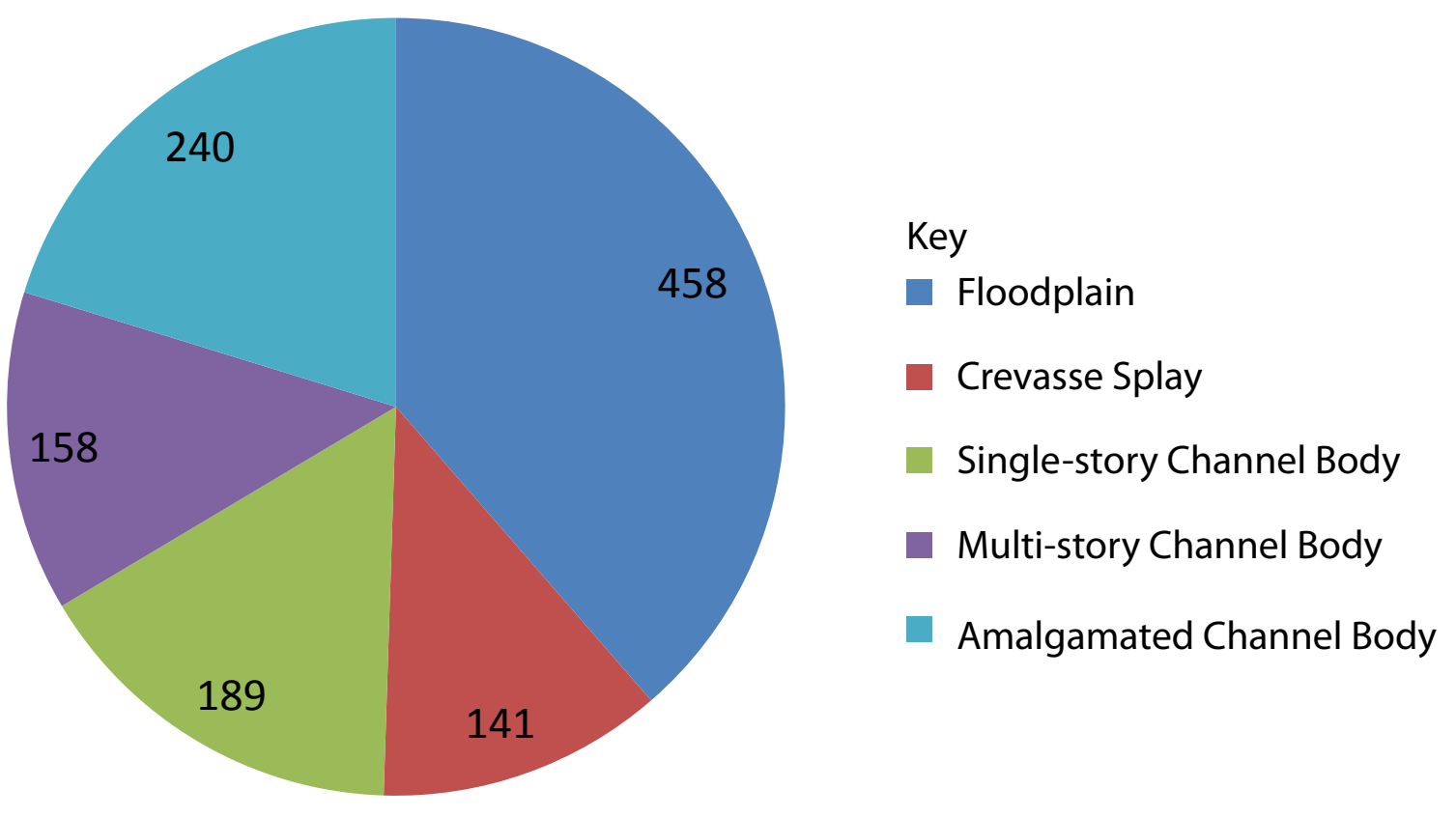




\section{Appendix D:}

\section{Gamma Ray Well Log Curve Normalization}

Well log curve normalization schemes typically work best when petrophysical and statistical analyses for curve shifting are trained on a relatively homogeneous unit with fixed properties such as an evaporite sequence, a "clean" marine shale (low quartz component), or a volcanic ash unit that is laterally continuous across the study area (Geauner, et al. 2004). However, because of the relatively discontinuous nature of the deposits in this study, such a laterally continuous, homogeneous layer does not exist within the study interval. Instead, GR normalization was implemented by normalizing GR curves to type well GR distributions. First, pre-normalization mapping was conducted in an attempt to reveal geologic trends/controls present across the study area. To do this, net-to-gross sandstone values were calculated in all wells over the study interval and the resulting values were mapped throughout the study area. To preserve what may be true spatial geologic differences revealed by pre-normalization mapping, normalization zones were created that correspond to areas of similar net-to-gross sandstone values. For each normalization zone, a few wells which possessed representative looking GR curves were selected as type wells (Figure 1A). The GR curves from these type wells were used to create a single cumulative GR histogram for each normalization zone. The GR curves of all other wells within the normalization zone were then normalized to the cumulative GR histogram via 2-point normalization in a multiwell histogram plot (Figures $2 \mathrm{~A}$ and $3 \mathrm{~A}$ ). Of the other well log curves utilized in this study, RHOB, ILD, and NPHI were left un-normalized due to the relatively low incidence of adjustments needed to correct these curves in modern logs and the high risk of imparting erroneous values during attempted normalization (Shier, 2004; Connolly 2012, personal communication). 


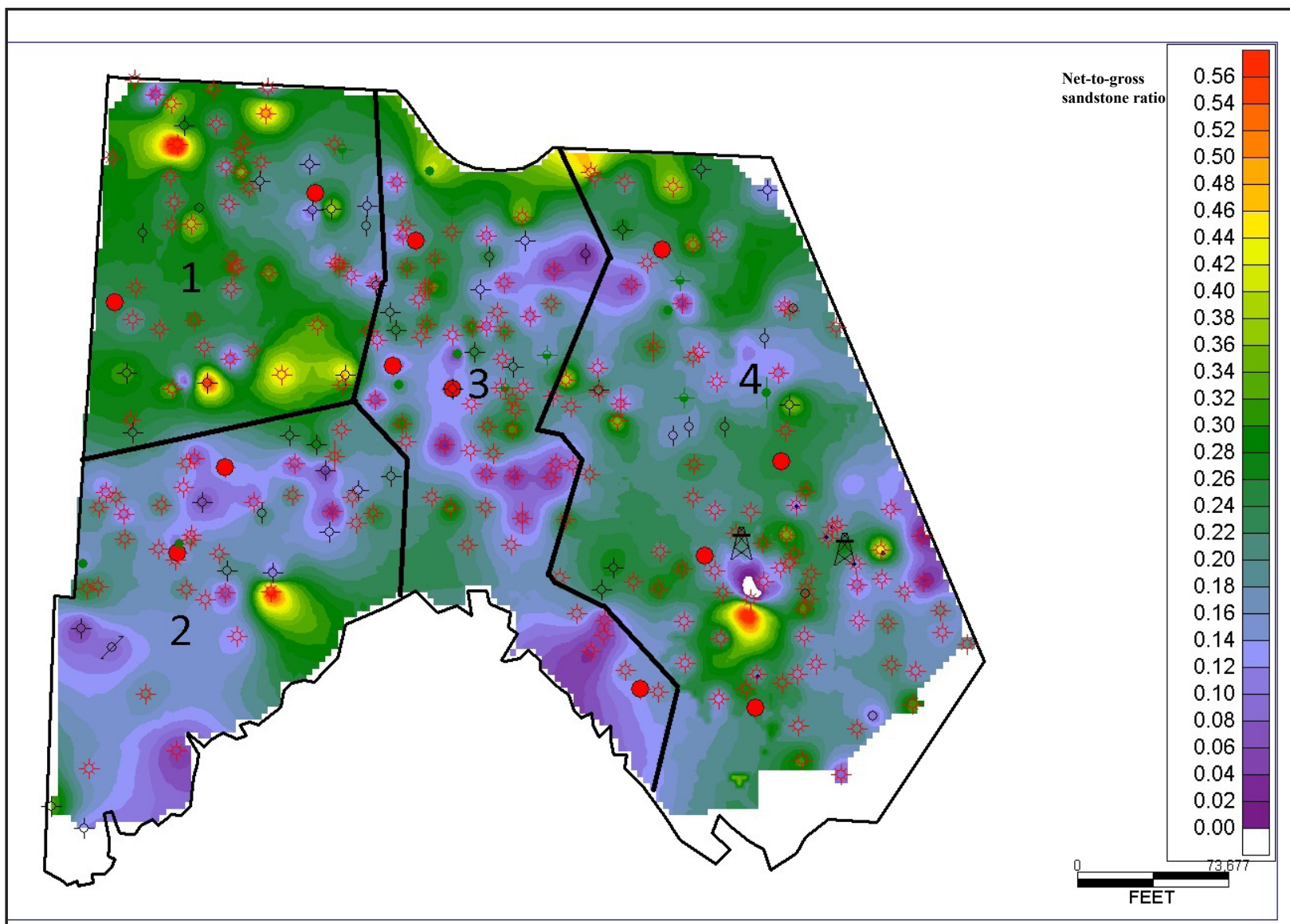

Figure 1A: Net-to-gross sandstone map calculated over the study interval throughout the study area that is divided into four zones of similar net-to-gross sandstone ratios. Type wells are seen in red. Zone three does not show consistently similar values however, similar log character observed in this area proximal to the Douglas Creek Arch, CO warranted segregation into a separate zone. 


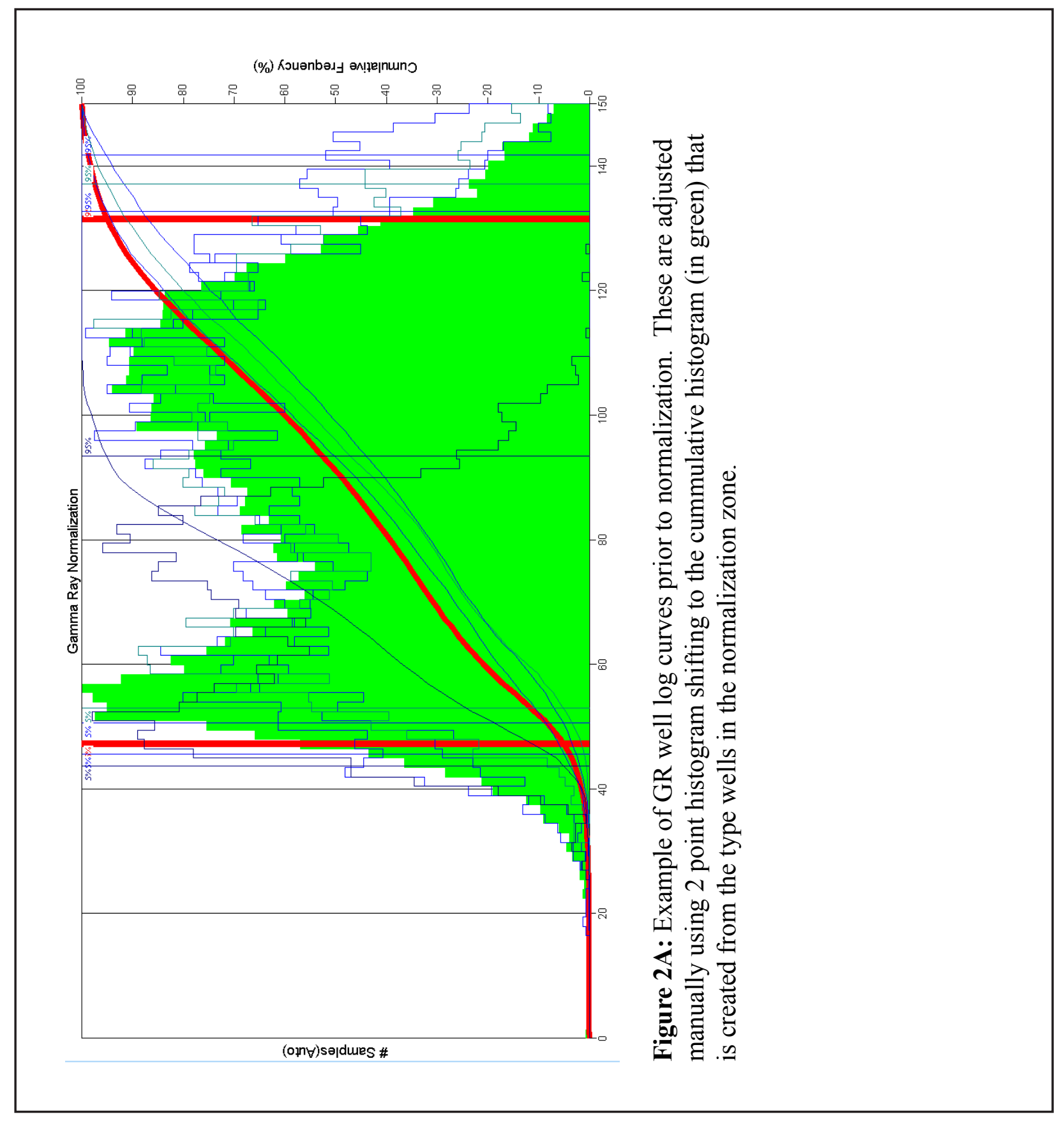




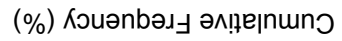

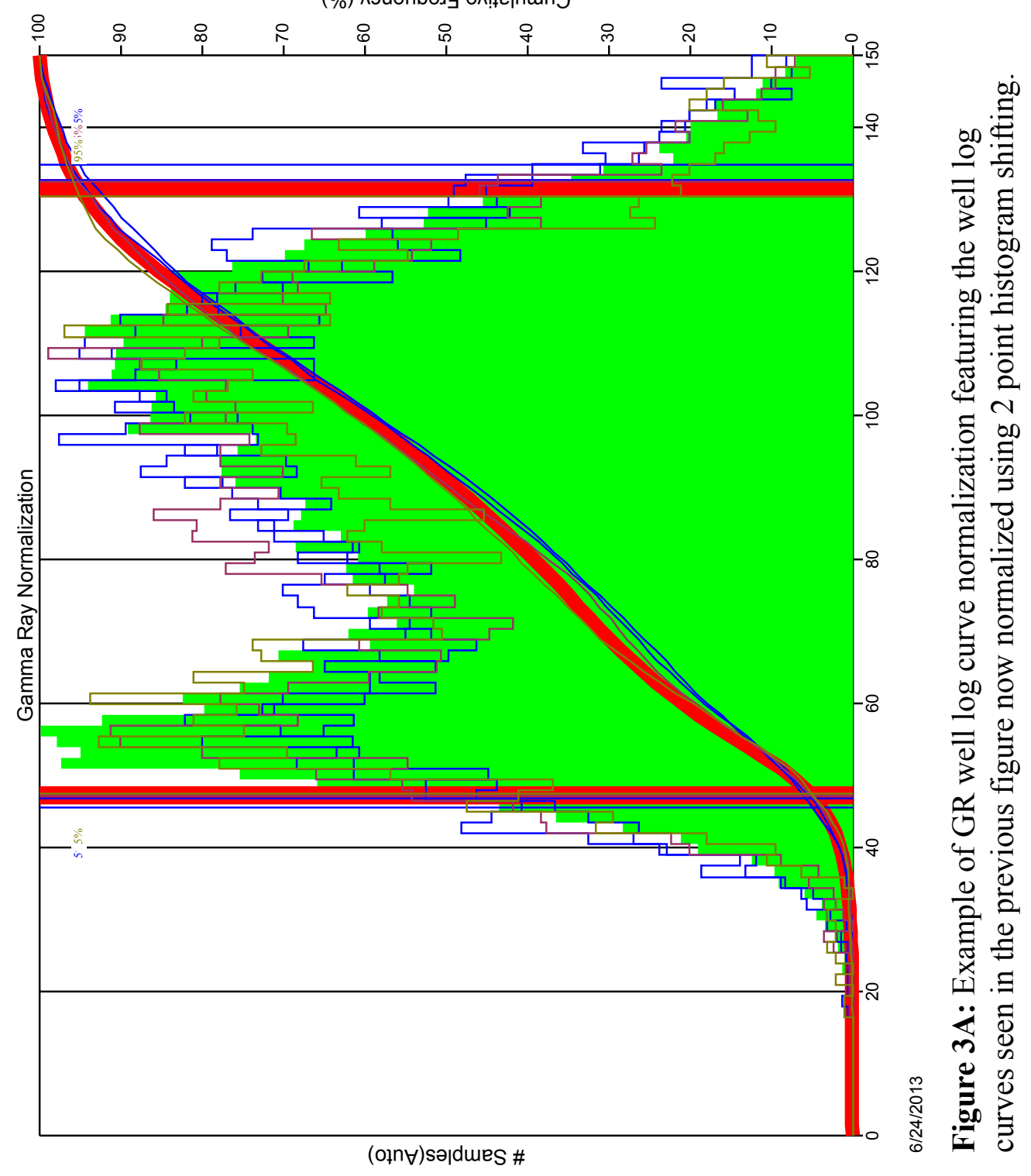


Appendix E

Core Description

Appendix E contains the sedimentologic description for 9 cores (total footage $1692 \mathrm{ft}$ [515.7 m]). Of the following cores CWU 854-33, Love Ranch Fee \#4, OXY 697-20-28, Skinner Ridge 698-21, and Federal 2-7 were used in the training of the electrofacies models while cores NBU 21, Federal Canyon 2-9, Orchard 16-12, and Williams PA-424-34 were utilized in testing the ability of the classifiers to correctly predict architectural element classes. Lithofacies and architectural-element abbreviations used in these descriptions can be found in their respective tables. 


\section{Stratification and Features}

\begin{tabular}{|c|c|}
\hline & Low-angle cross-stratification \\
\hline & High-angle cross-stratification \\
\hline & Trough cross-stratification \\
\hline & Planar Laminated \\
\hline & Wavy Bedding \\
\hline & Convoluted Bedding \\
\hline & Ripple Stratification \\
\hline $\begin{array}{l}15 \\
4\end{array}$ & Bioturbation \\
\hline$-=$ & Mud chips \\
\hline$\lambda \pi$ & Root traces \\
\hline$\$$ & Carbonaceous Material \\
\hline
\end{tabular}

\section{Lithology}

\begin{tabular}{|c|c|}
\hline & Sandstone \\
\hline & Silty-sandstone \\
\hline$\therefore$ & Sandy-siltstone \\
\hline -二 & Siltstone \\
\hline$[-1$ & Mudstone \\
\hline
\end{tabular}




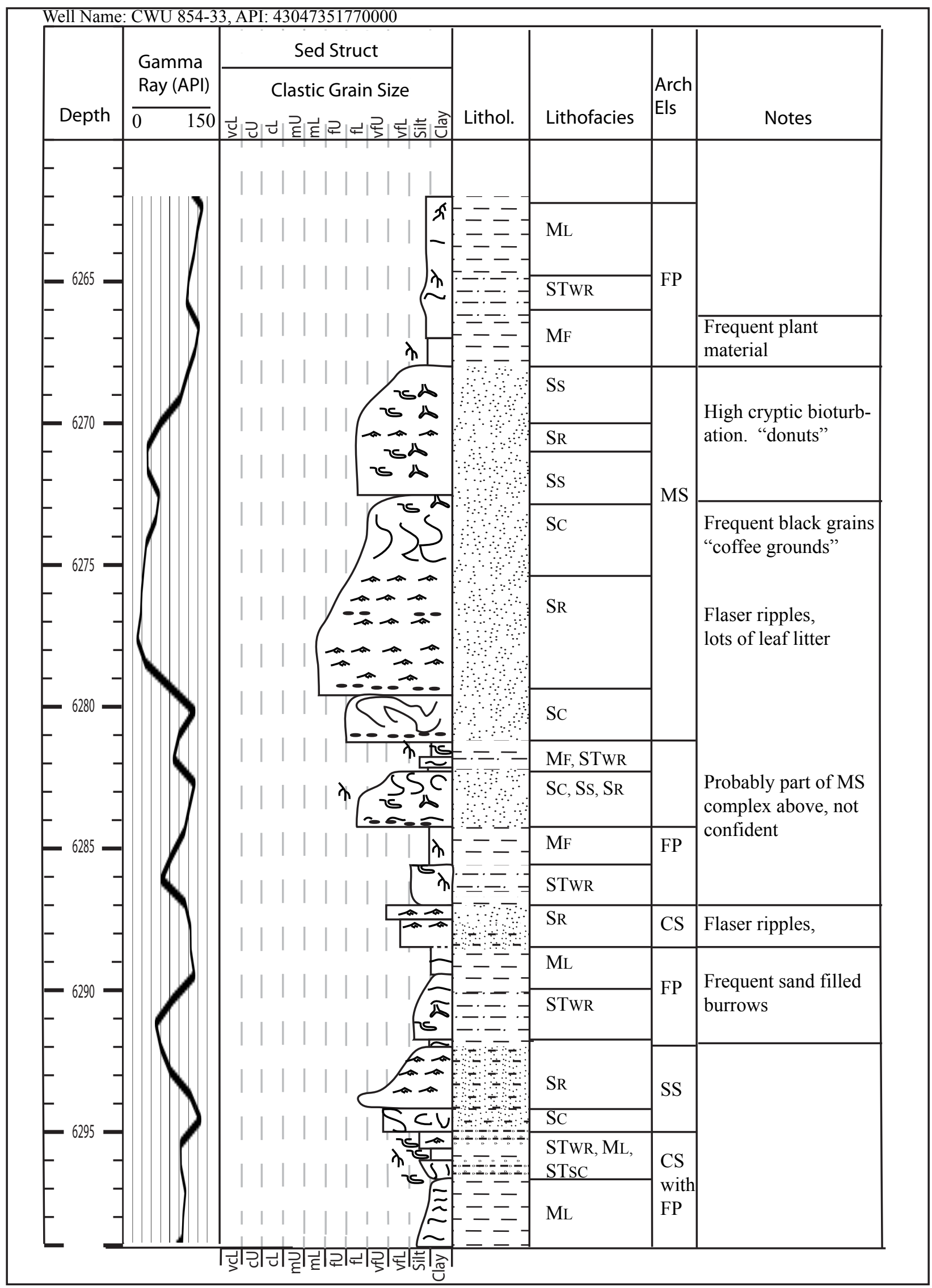




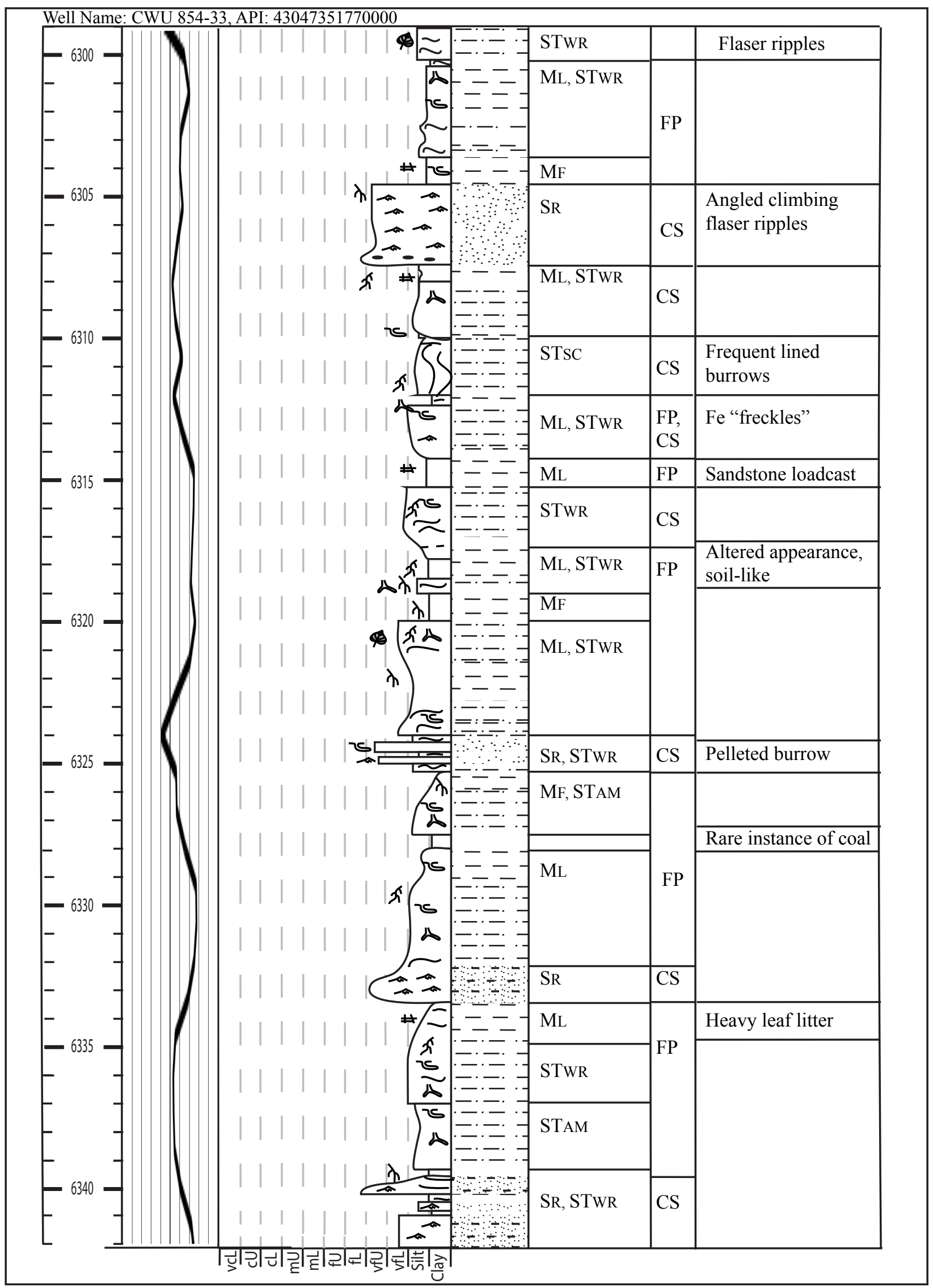




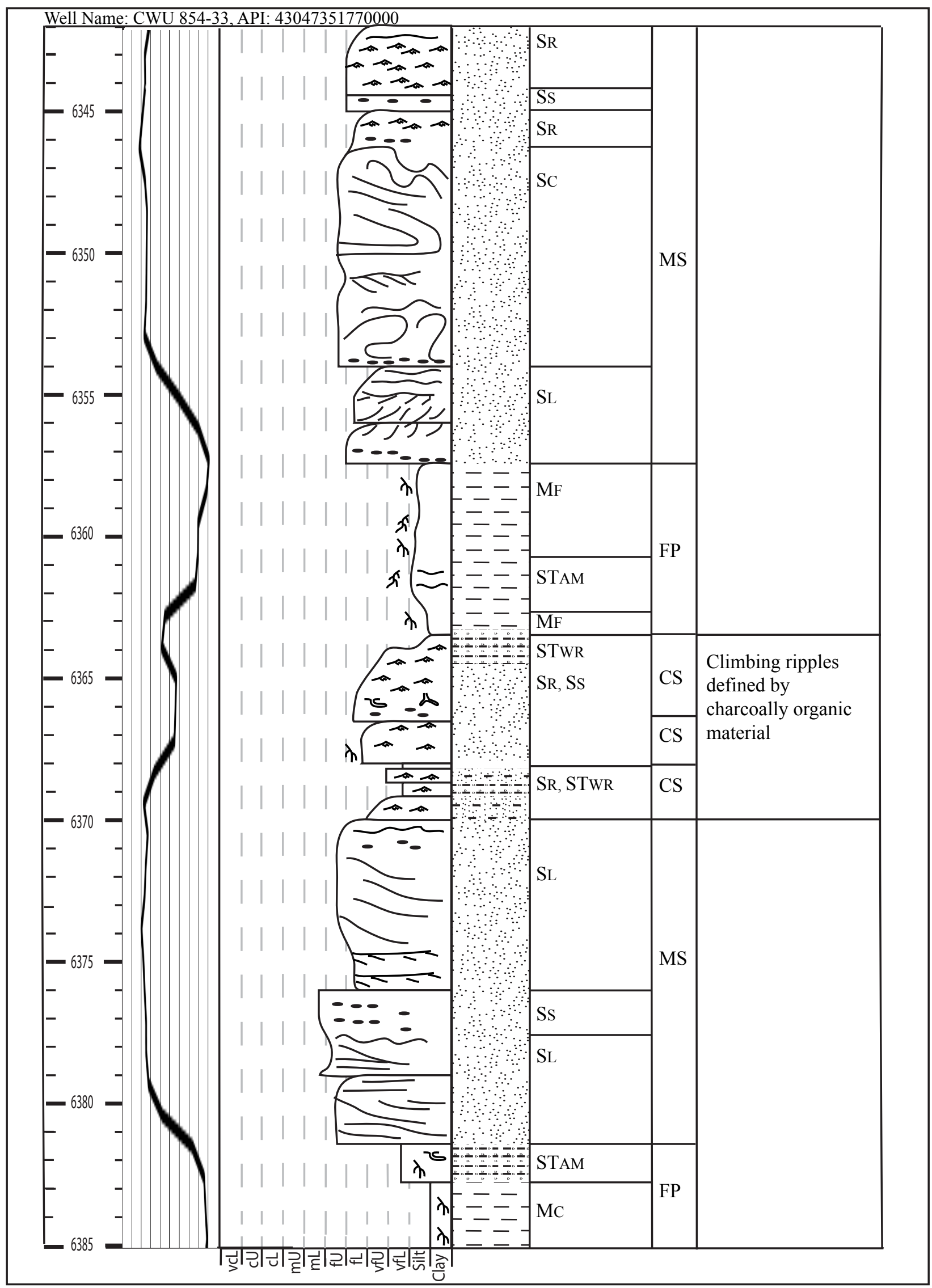




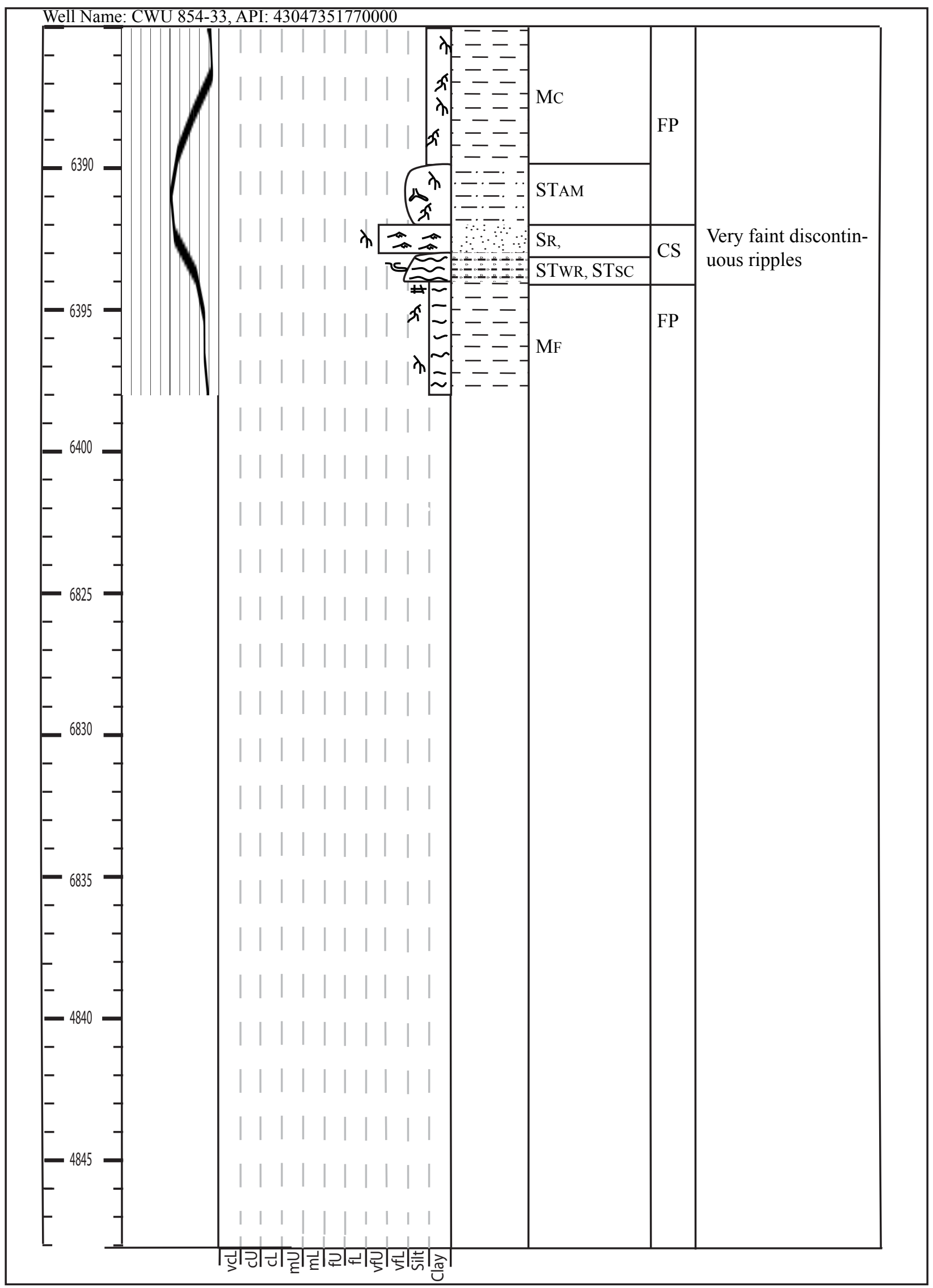




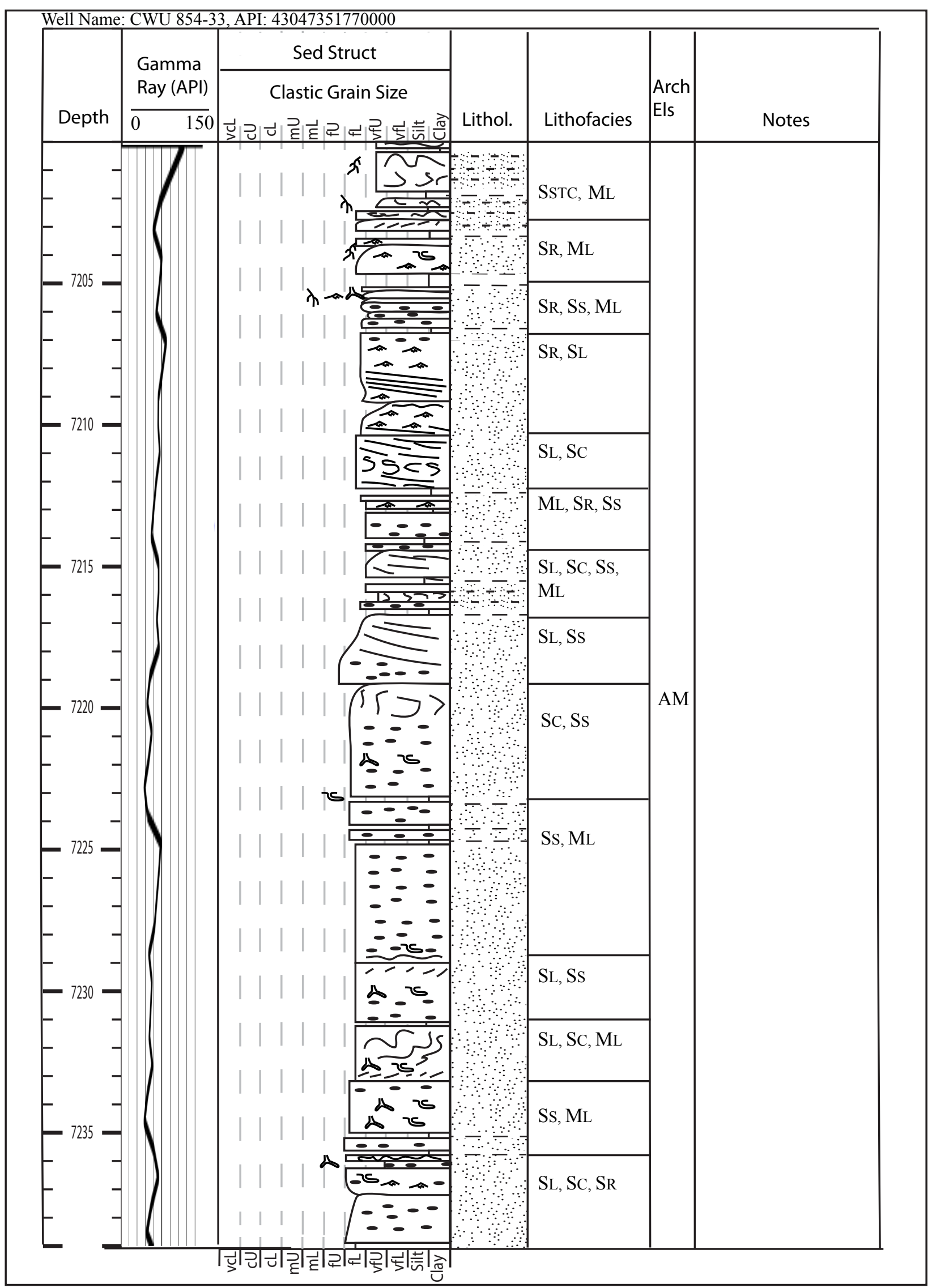




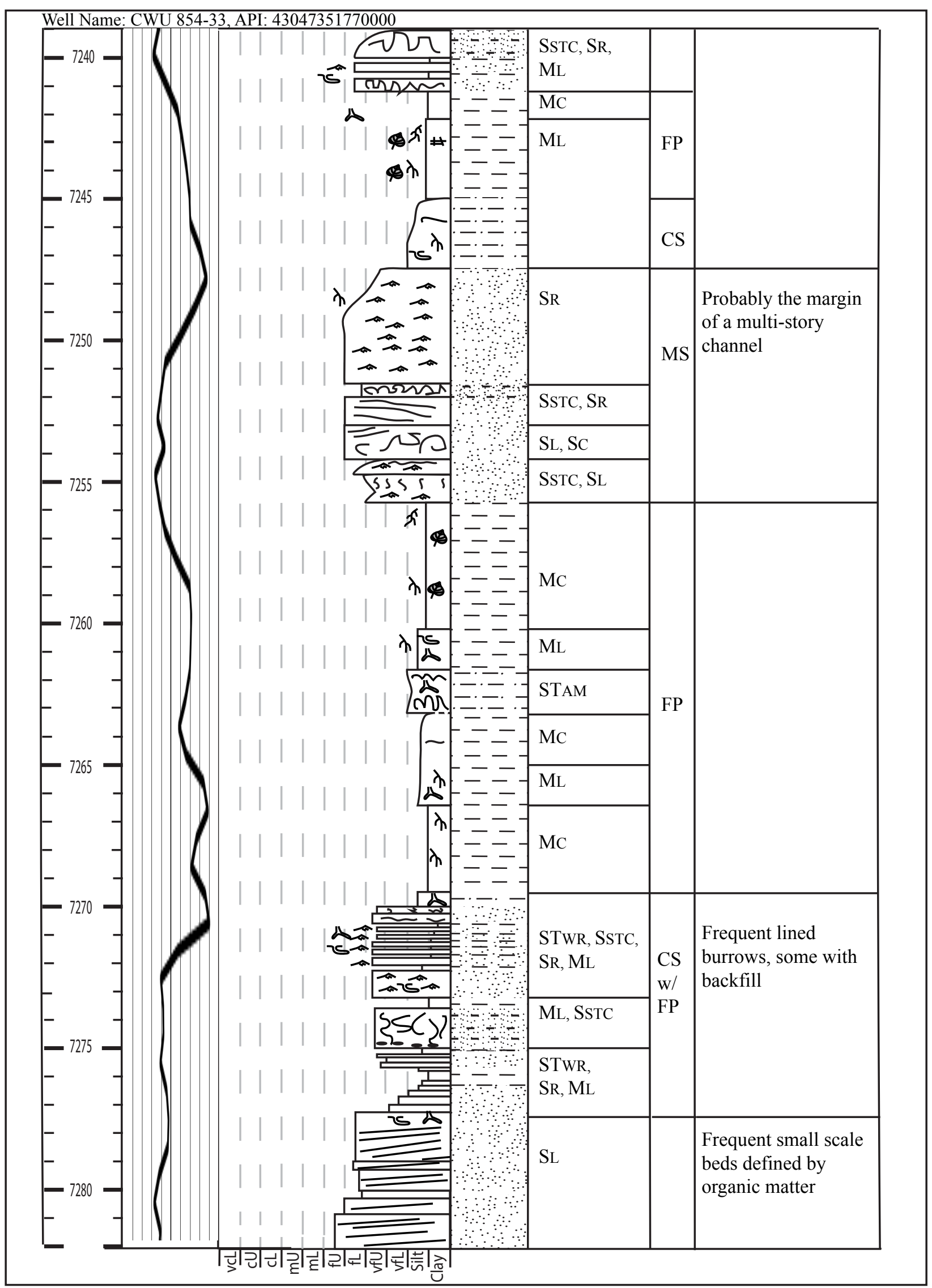




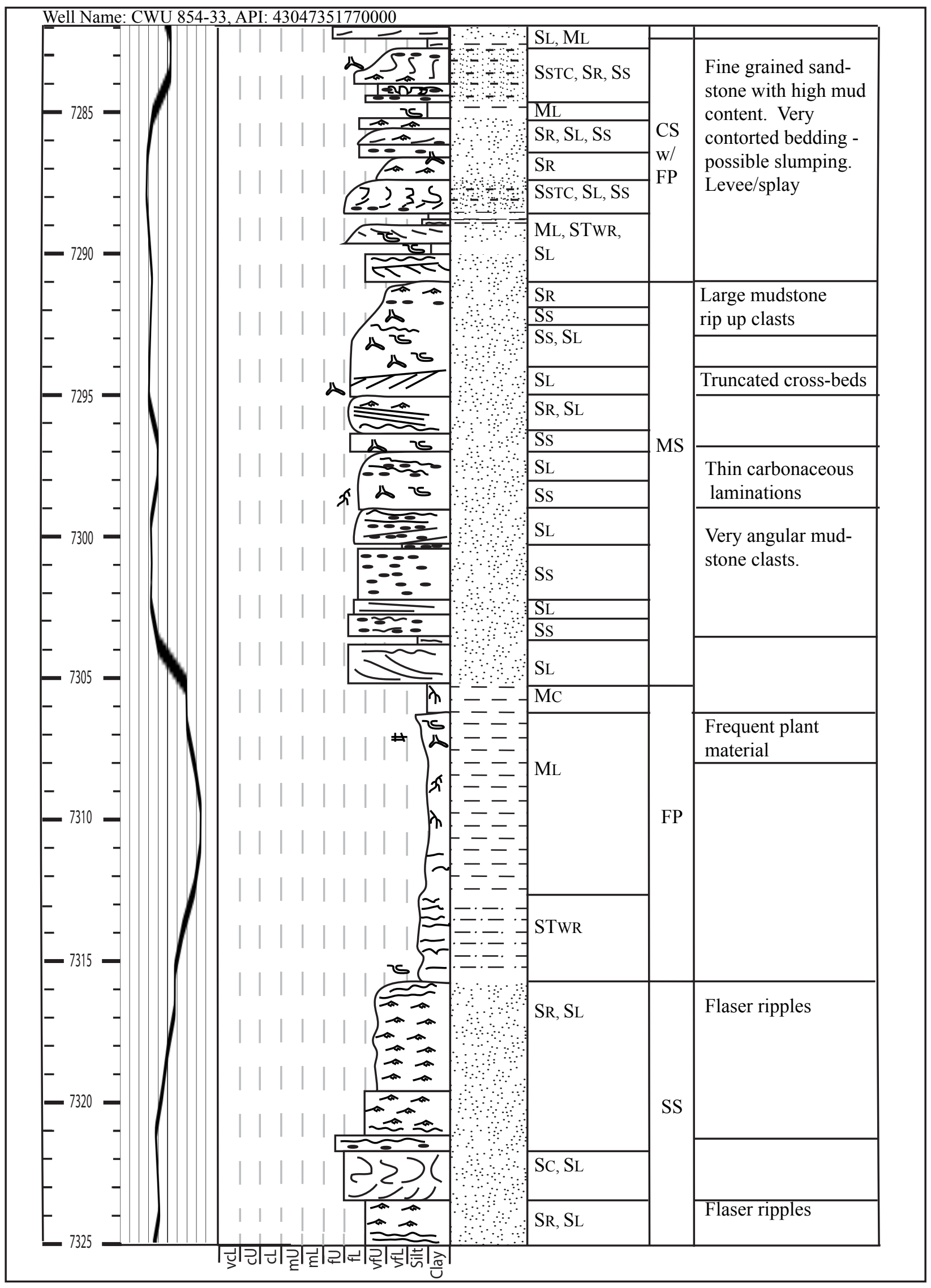




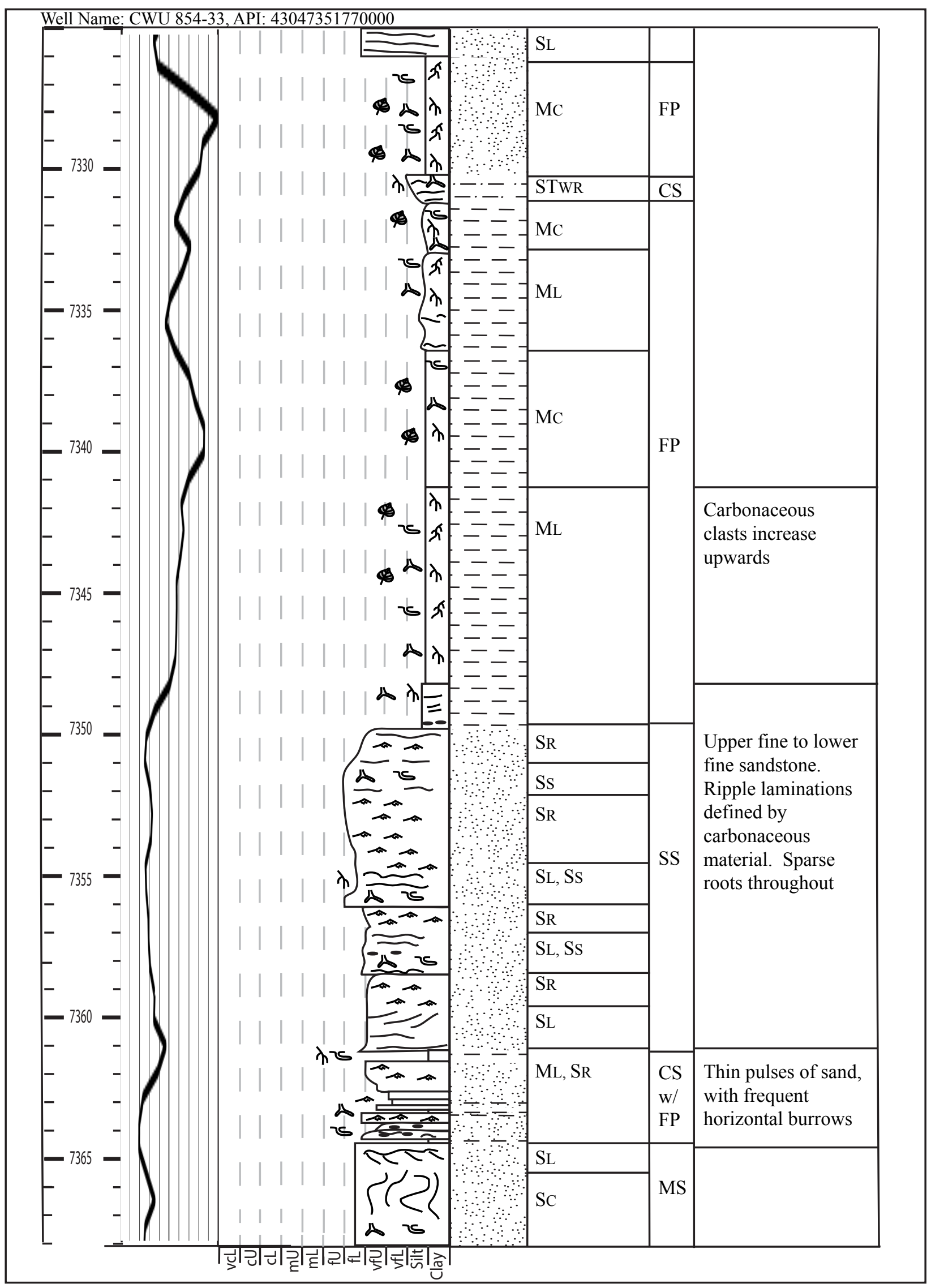




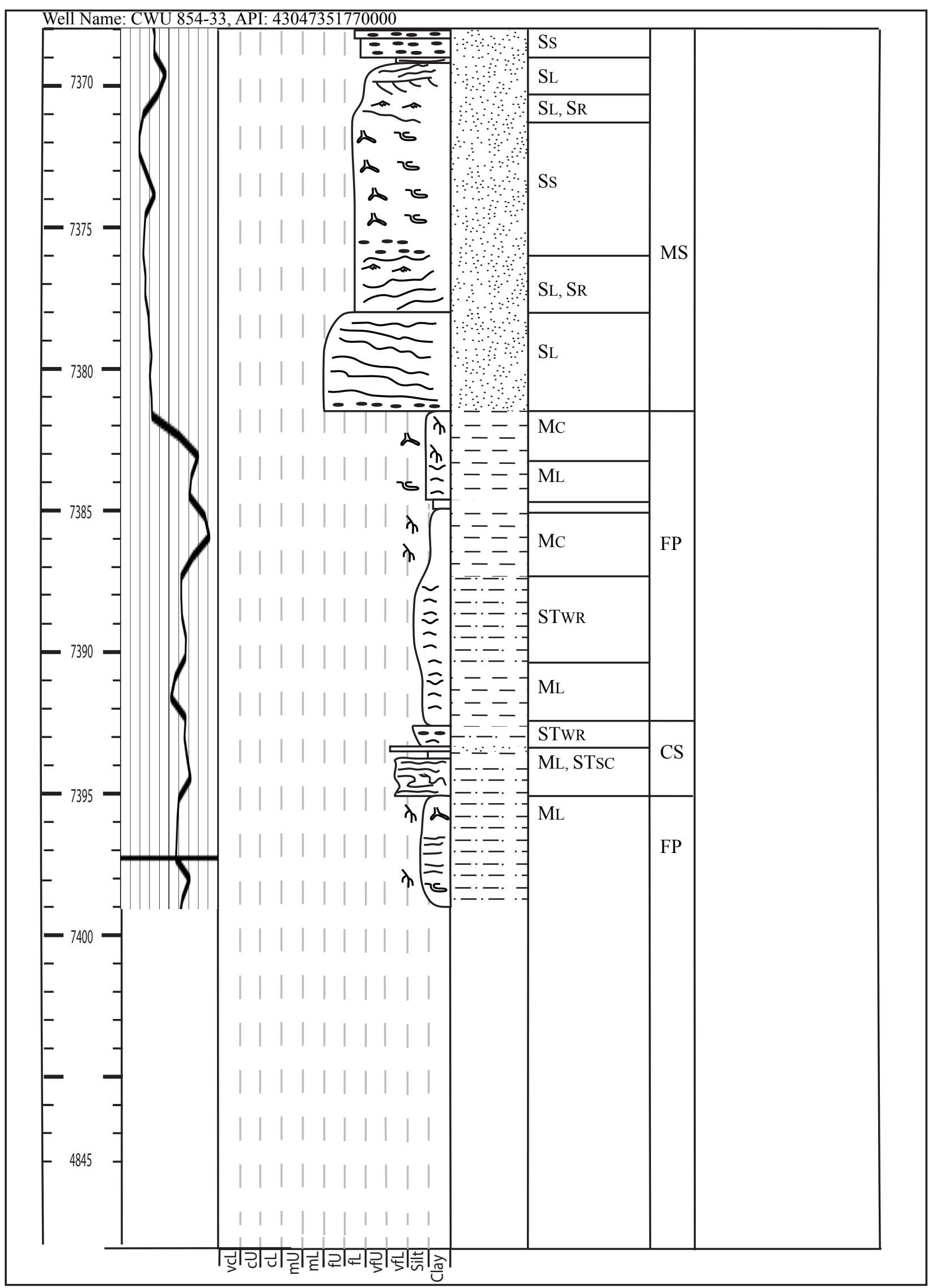




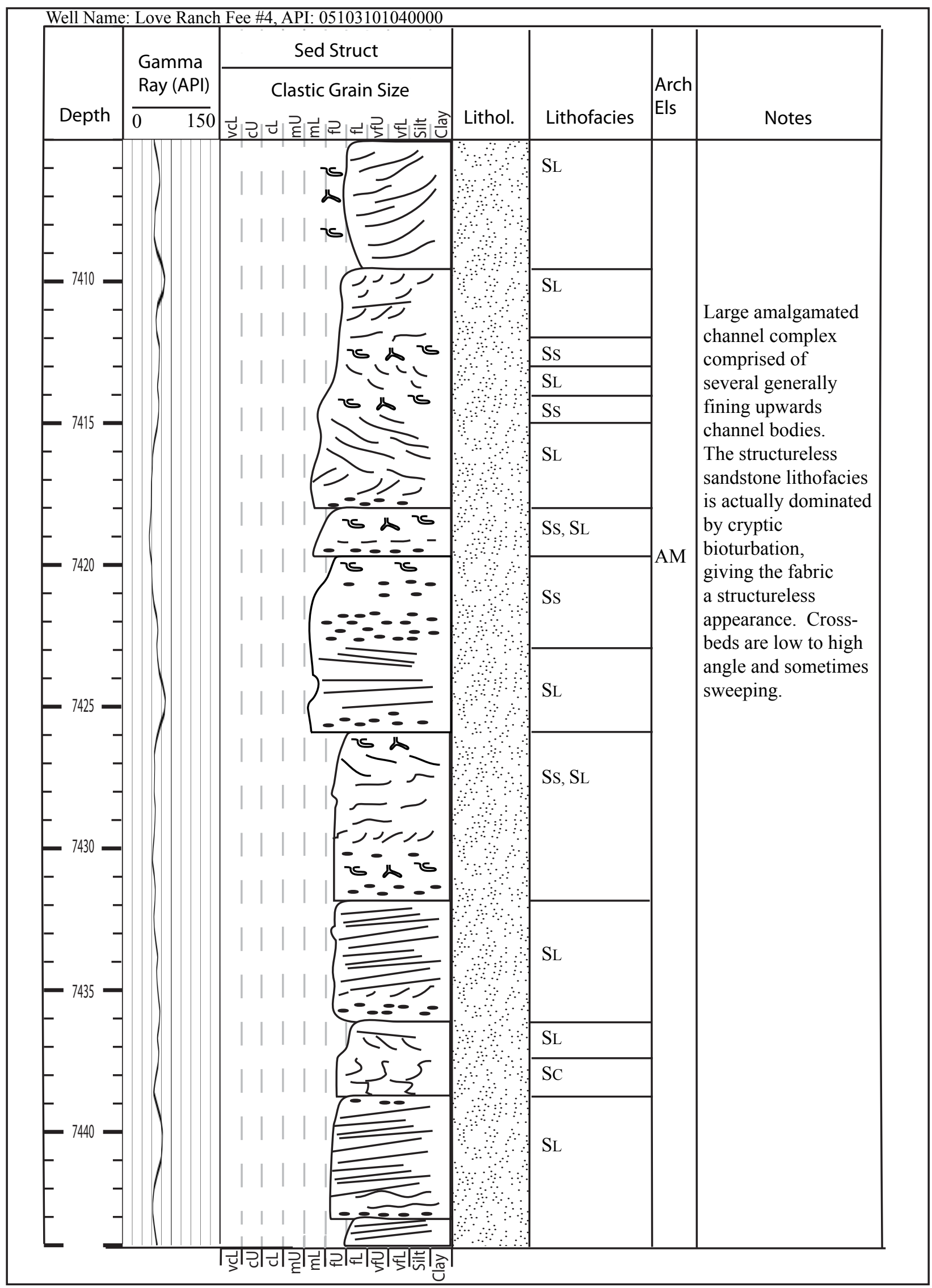




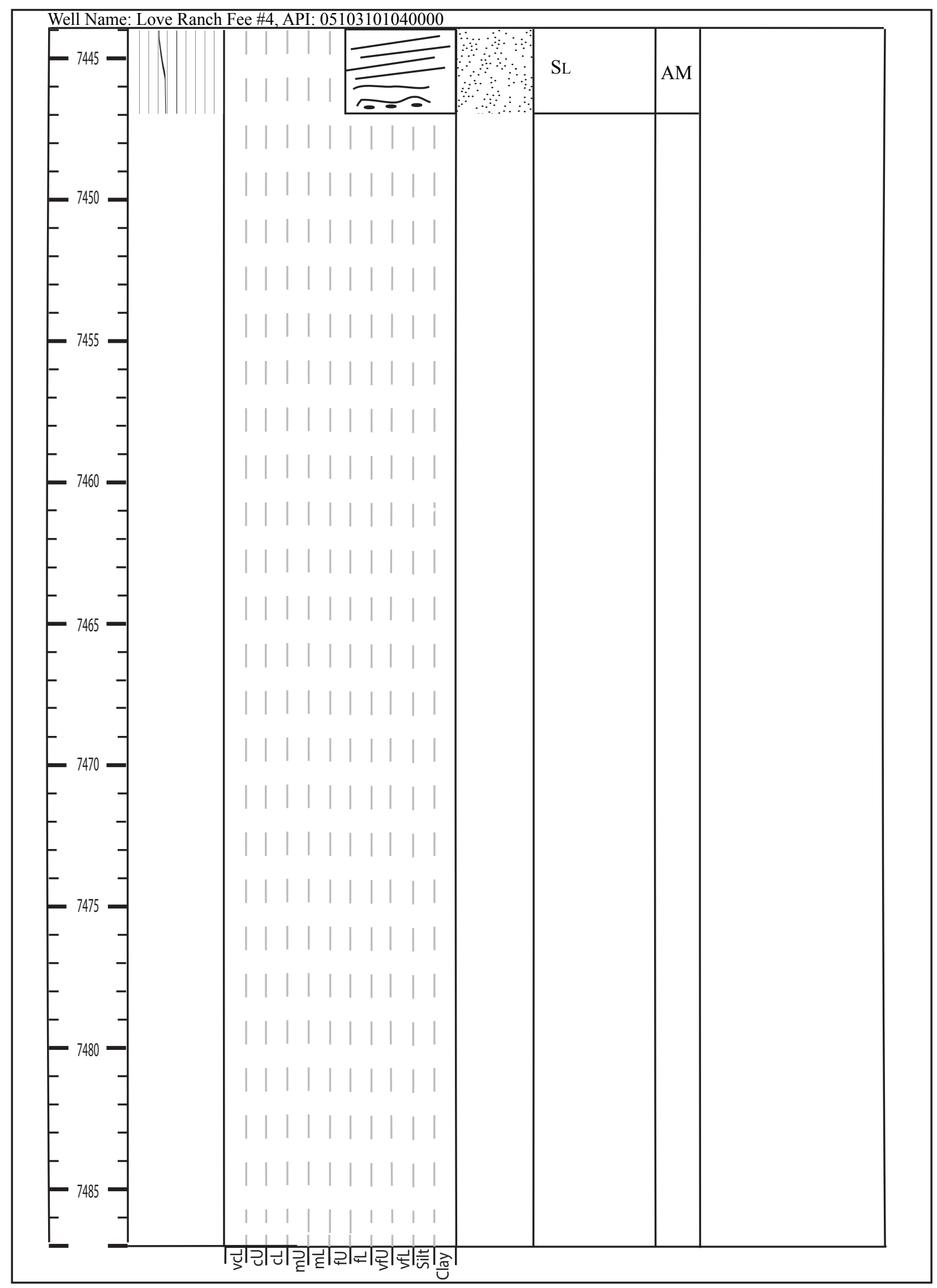


Well Name: Love Ranch Fee \#4, API: 05103101040000

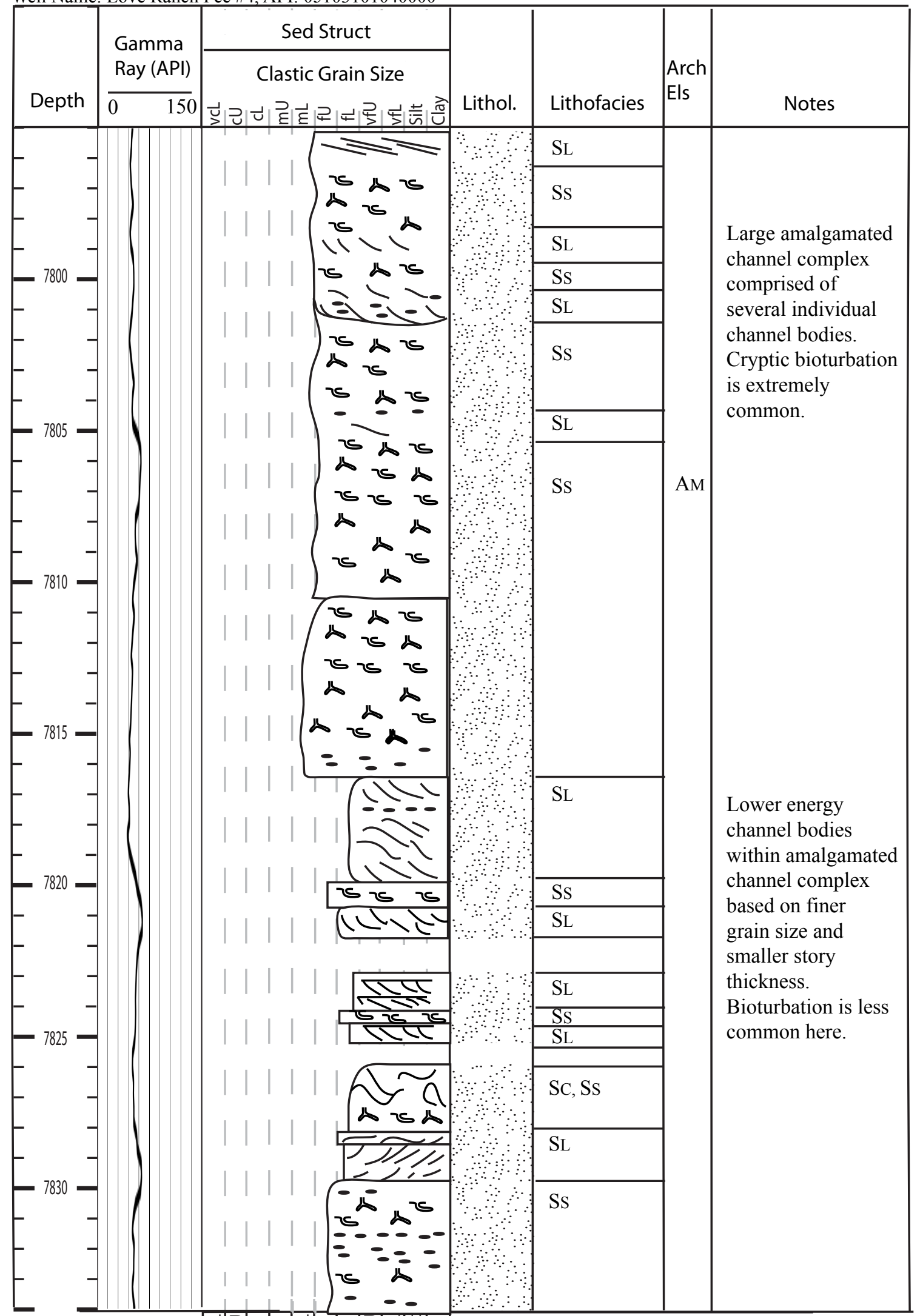

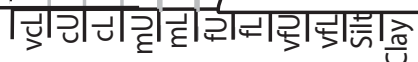




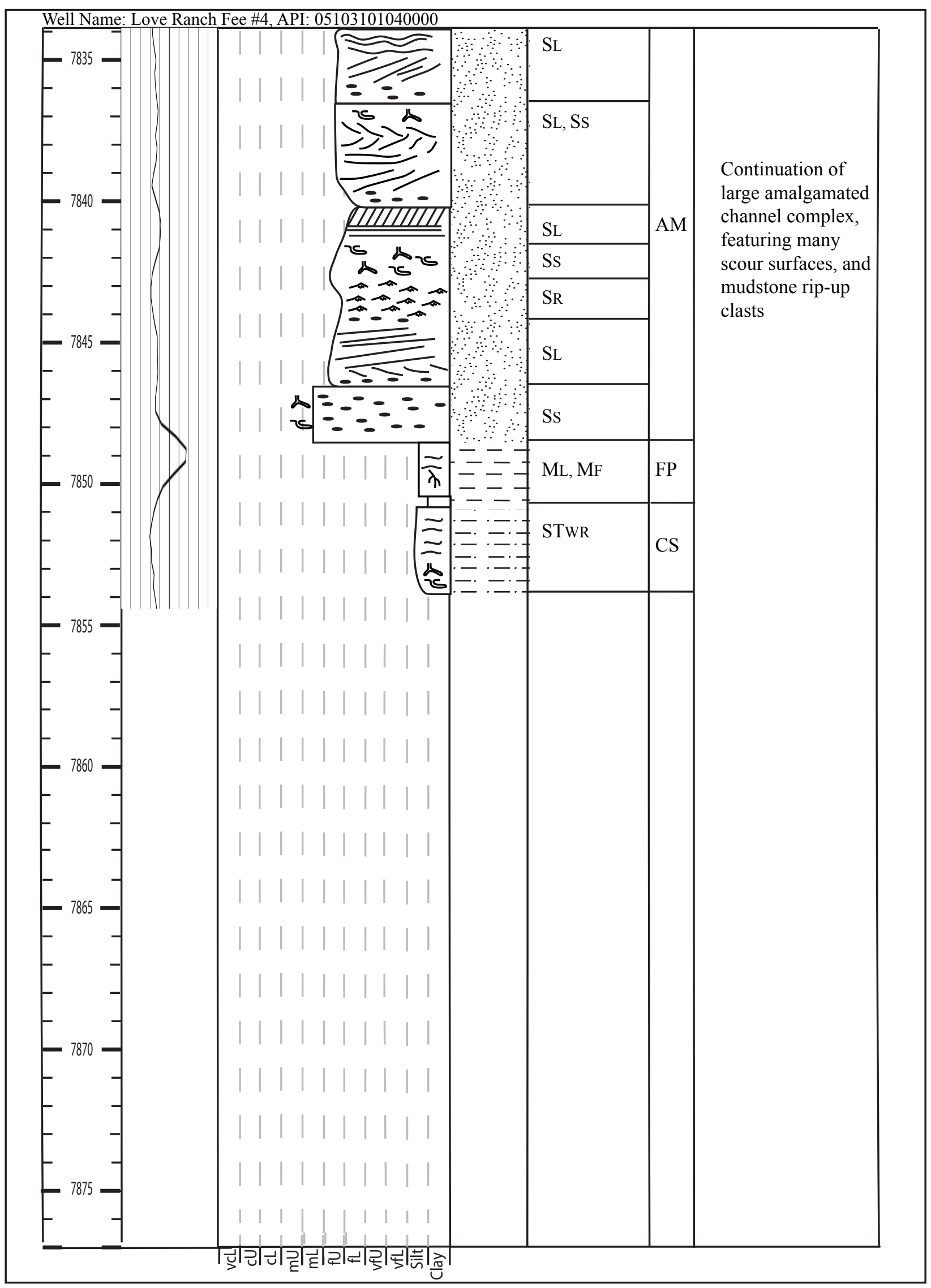


Well Name: OXY 697-20-28, API: 05045104770000

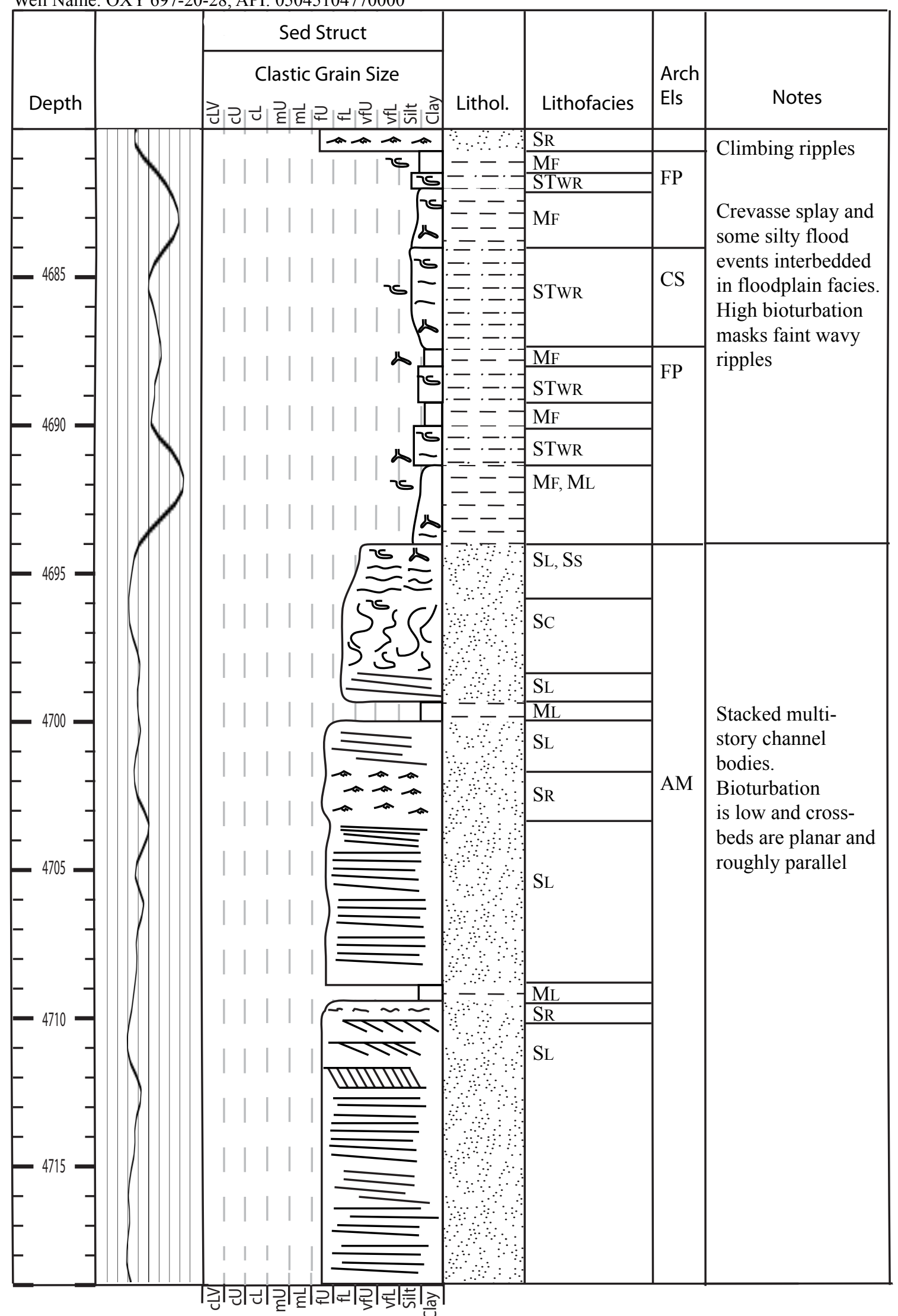




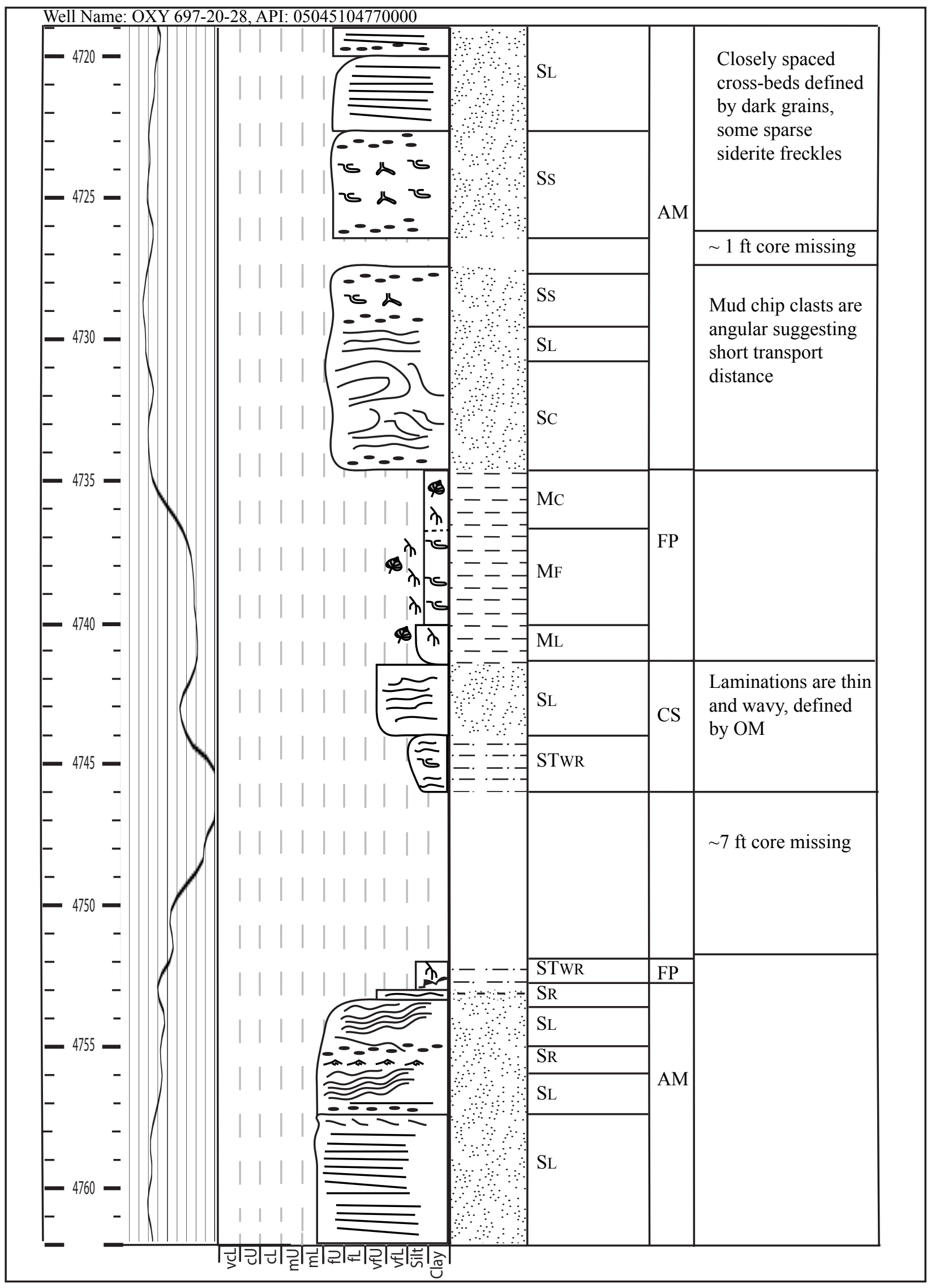




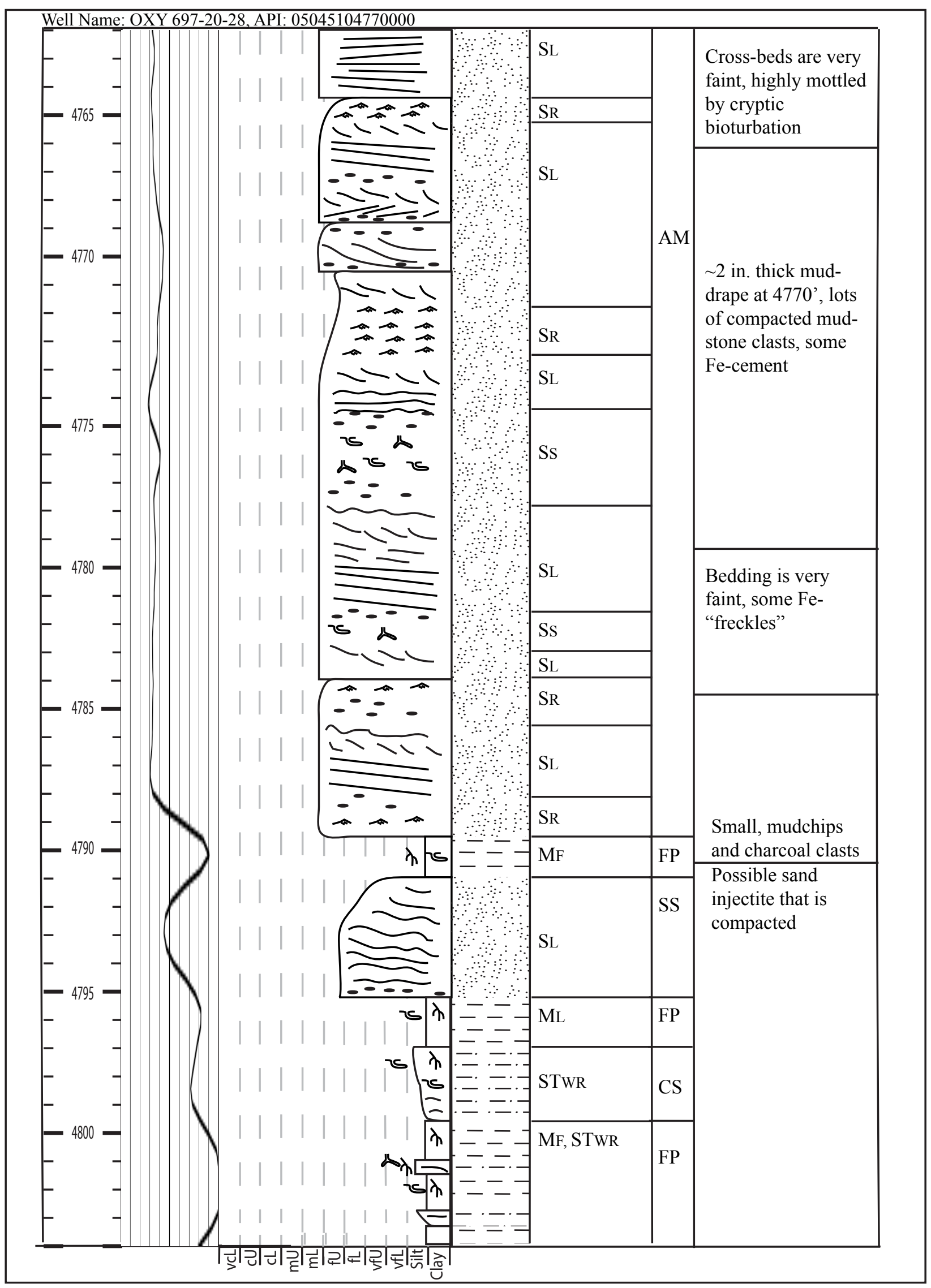




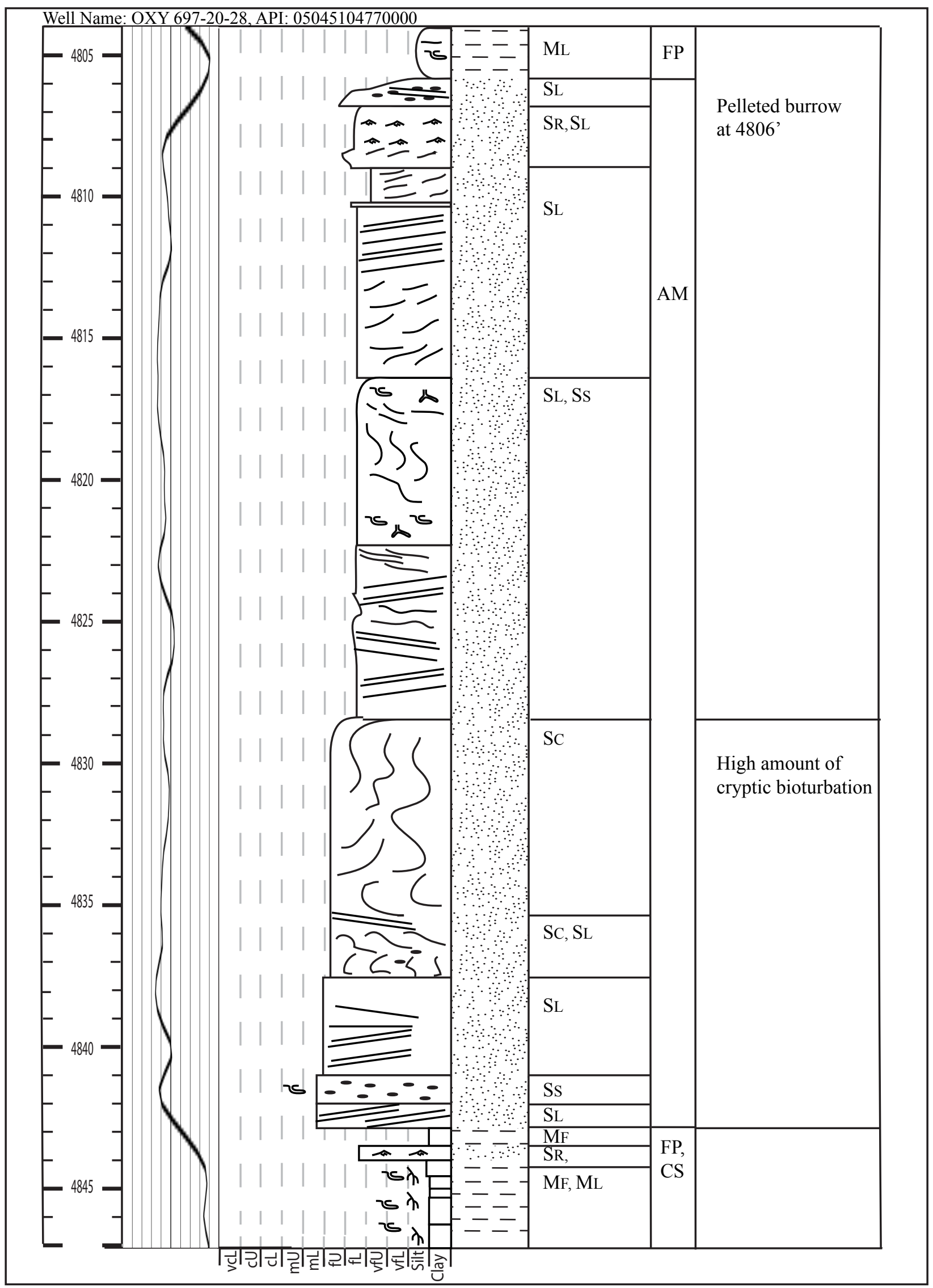




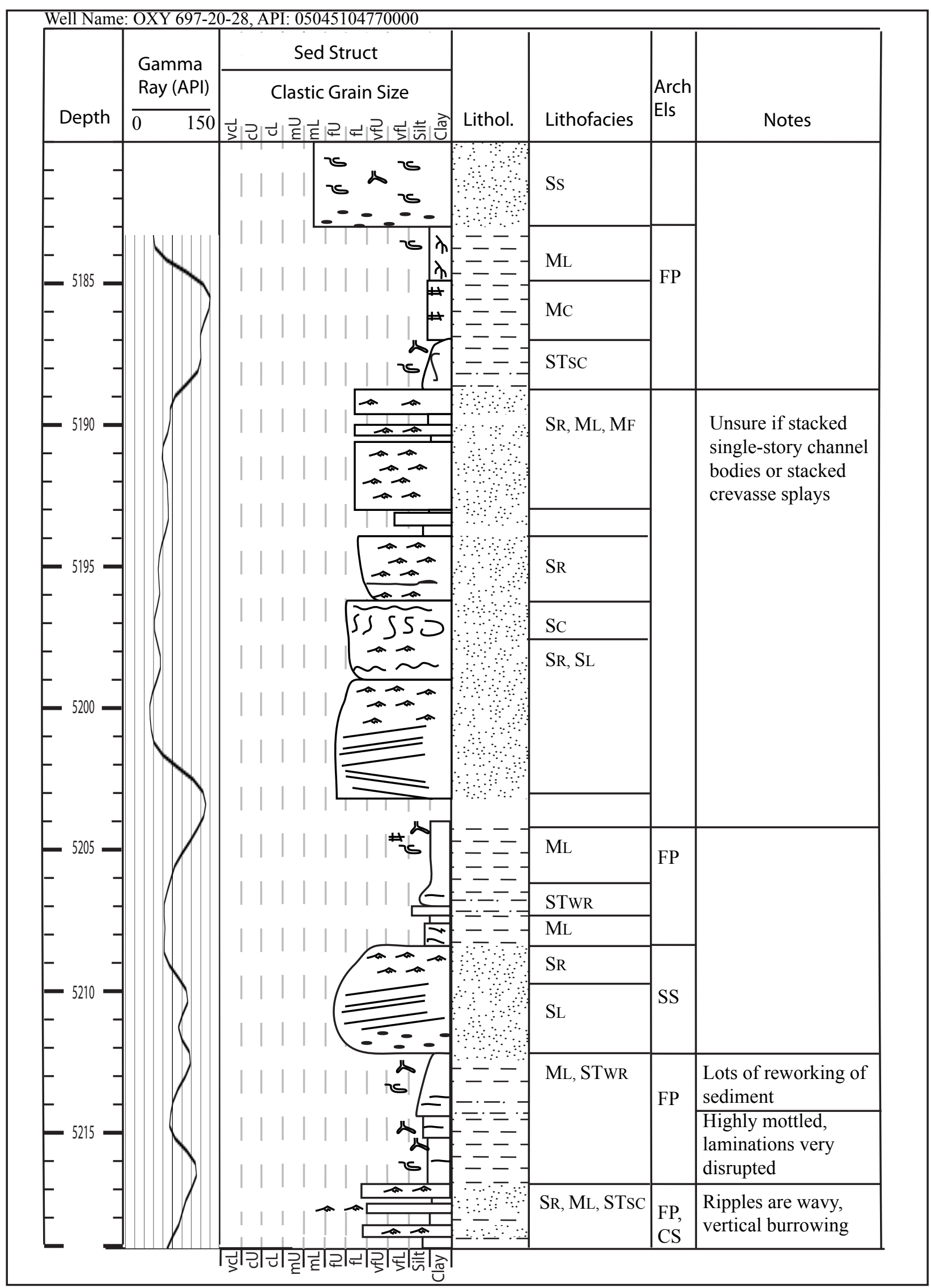




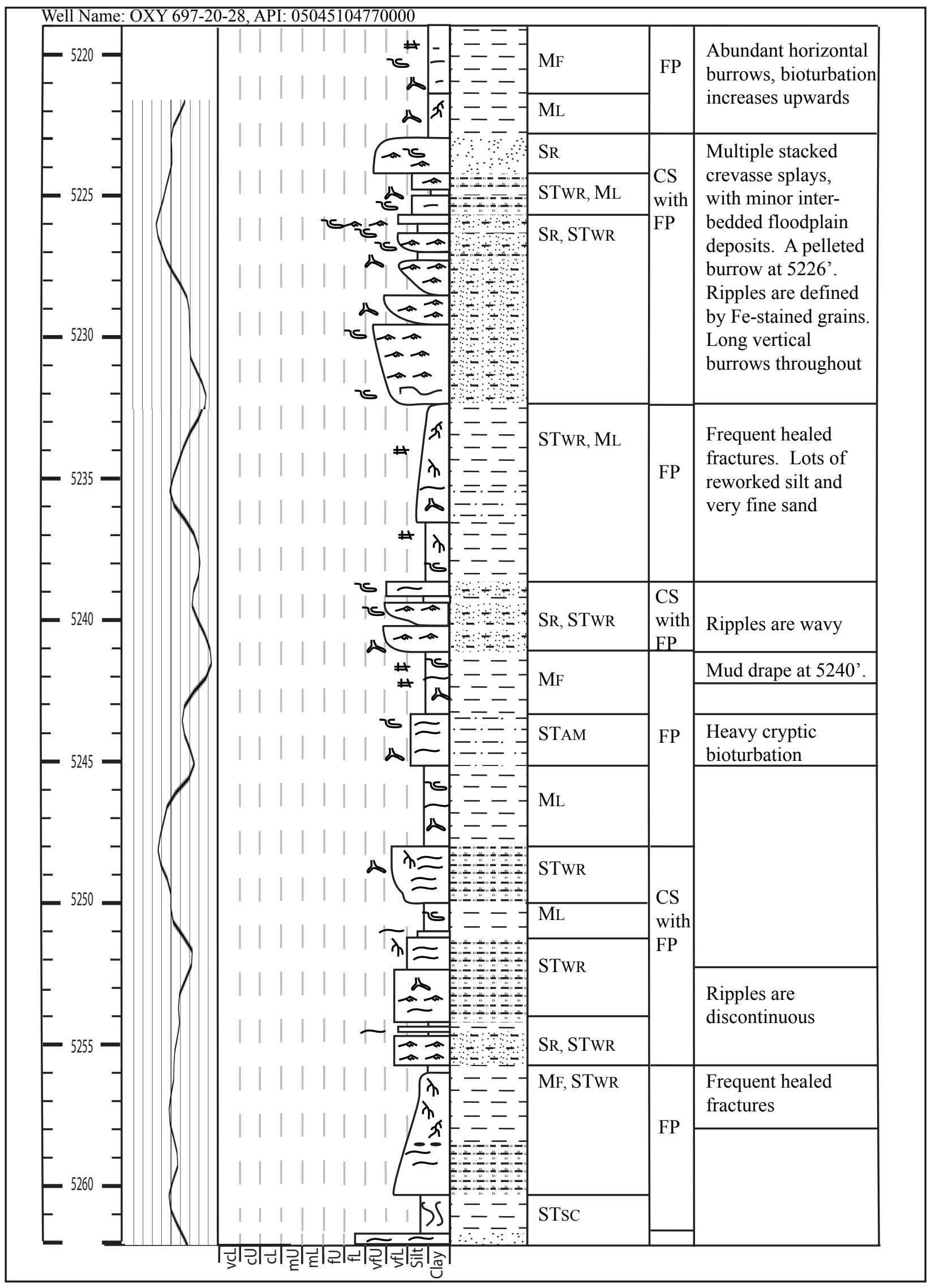




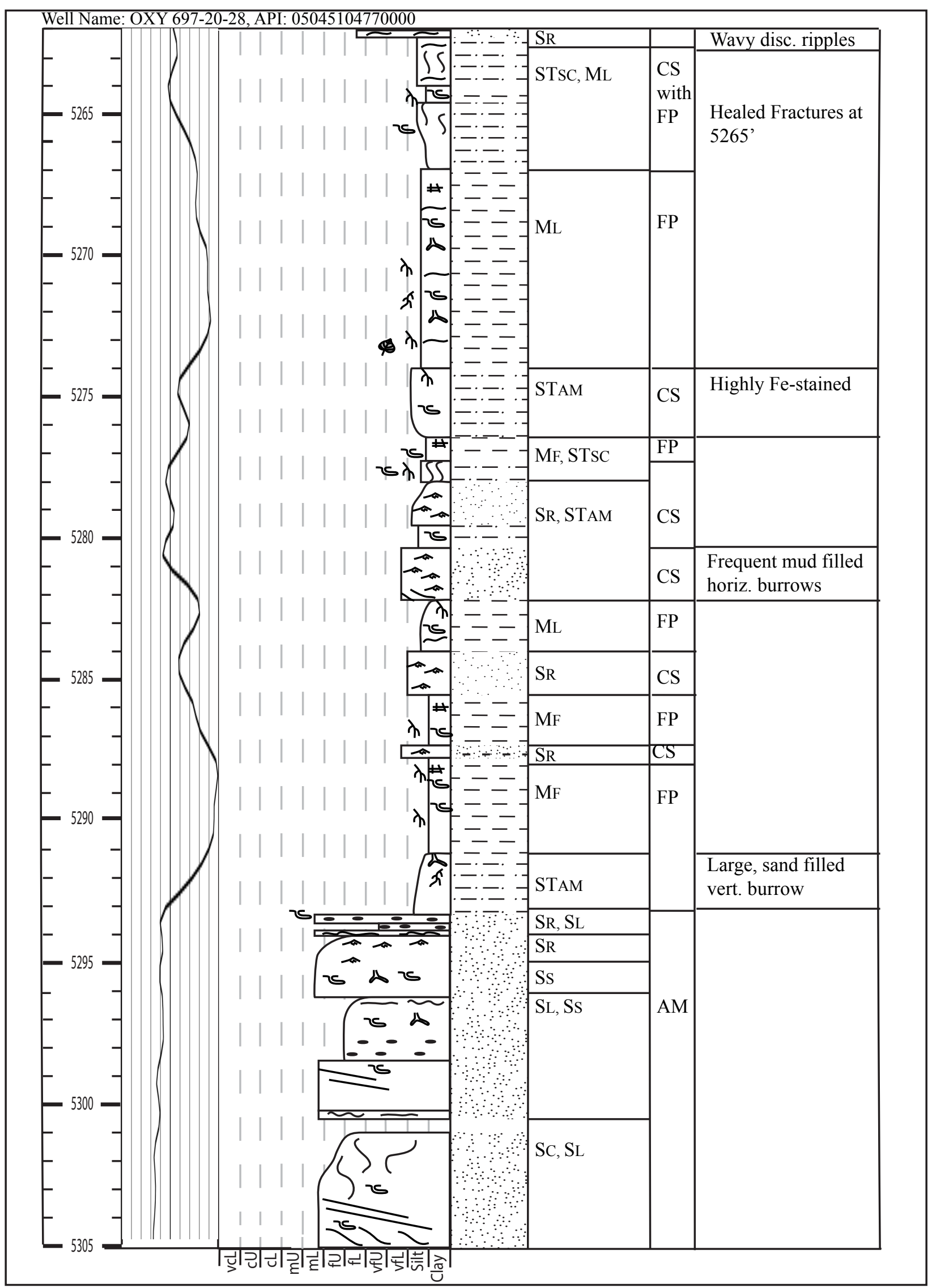




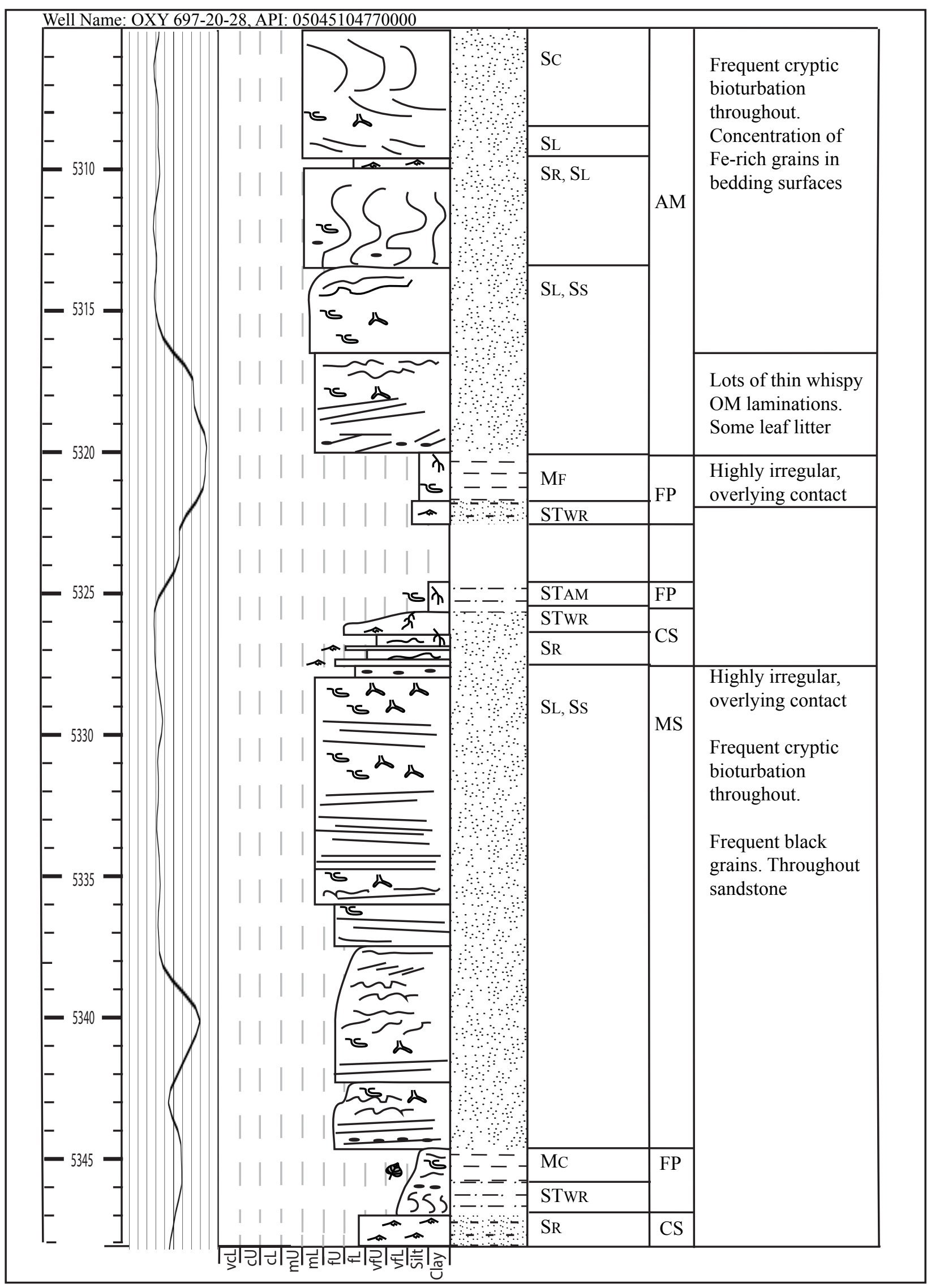


Well Name: OXY 697-20-28, API: 05045104770000

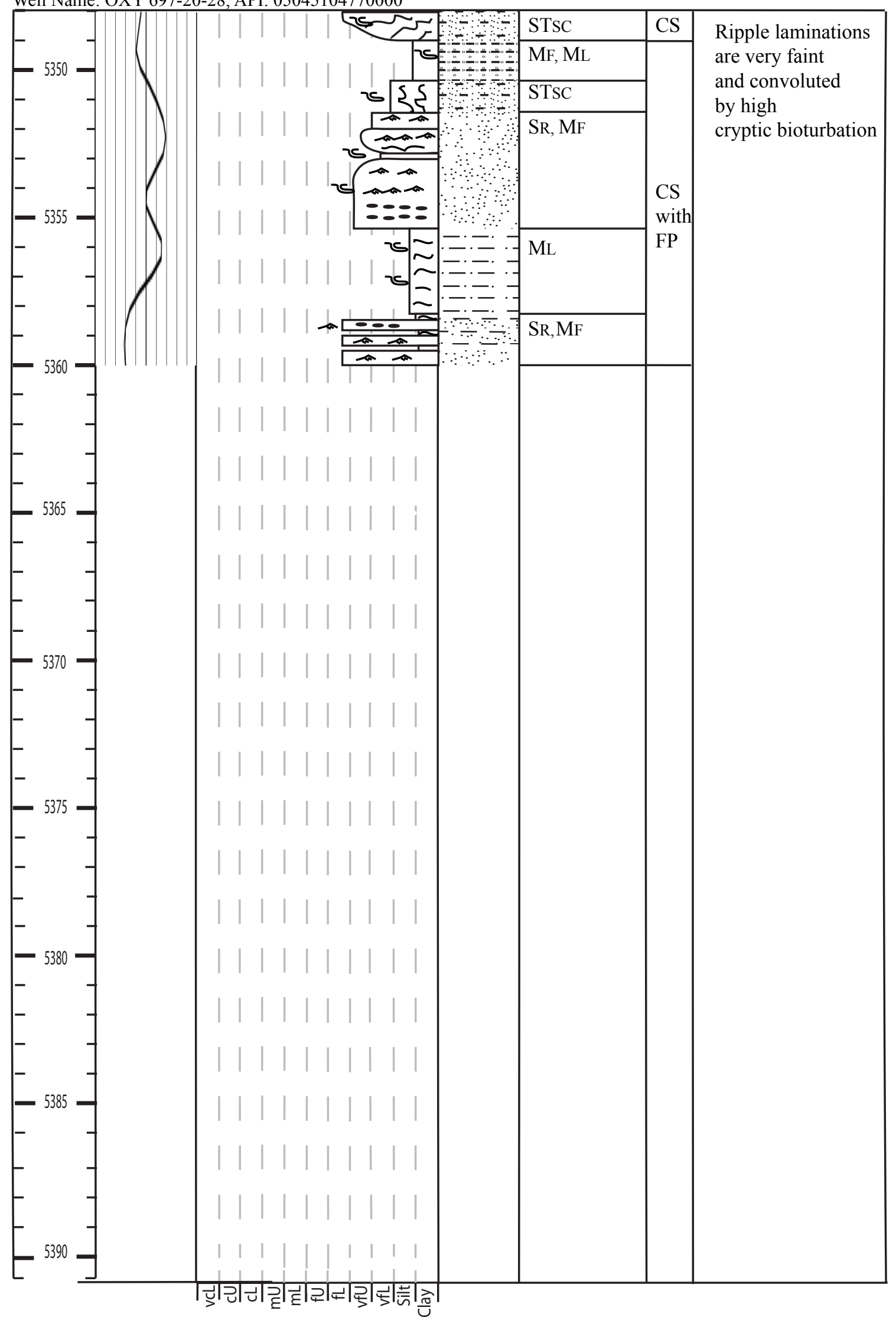




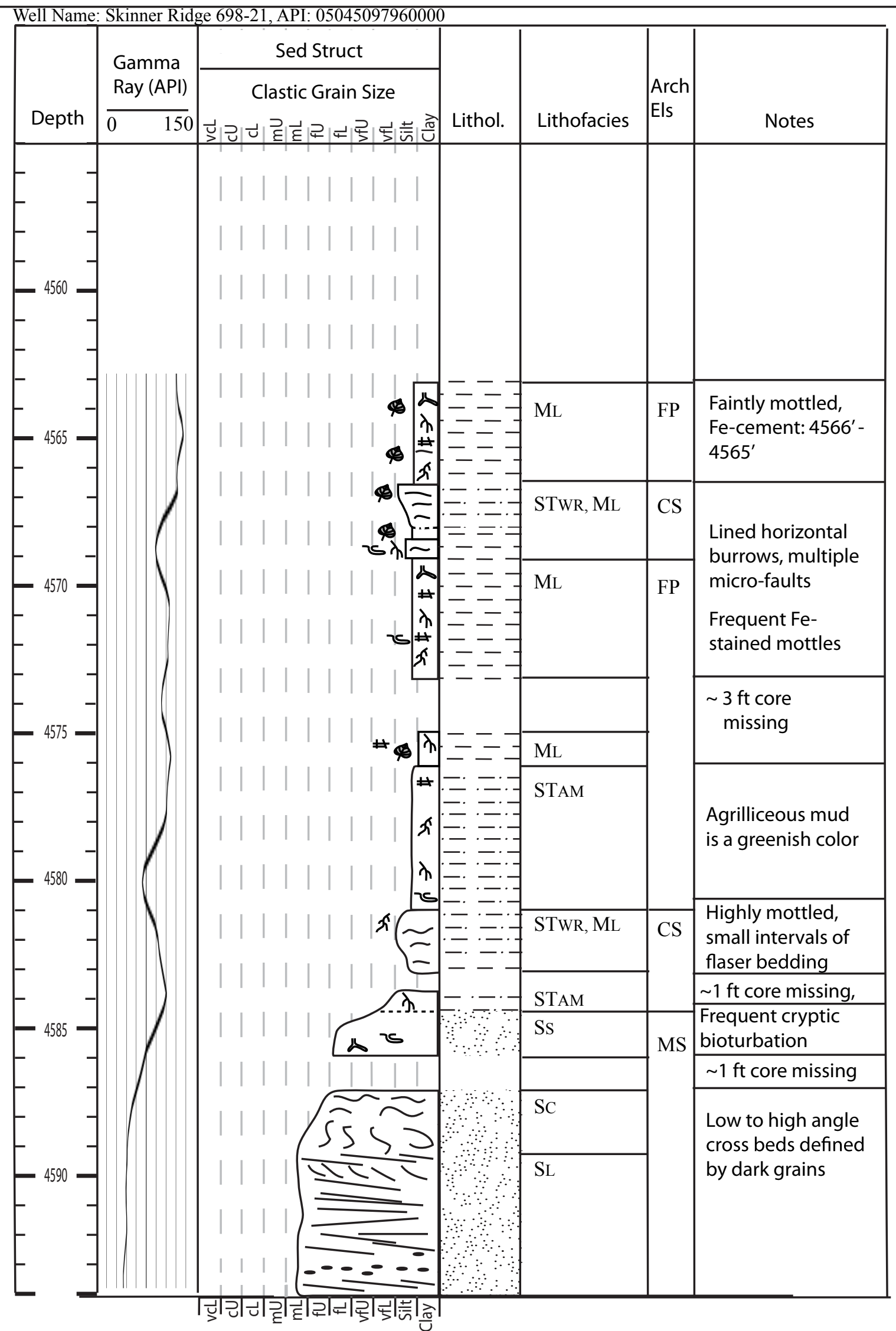




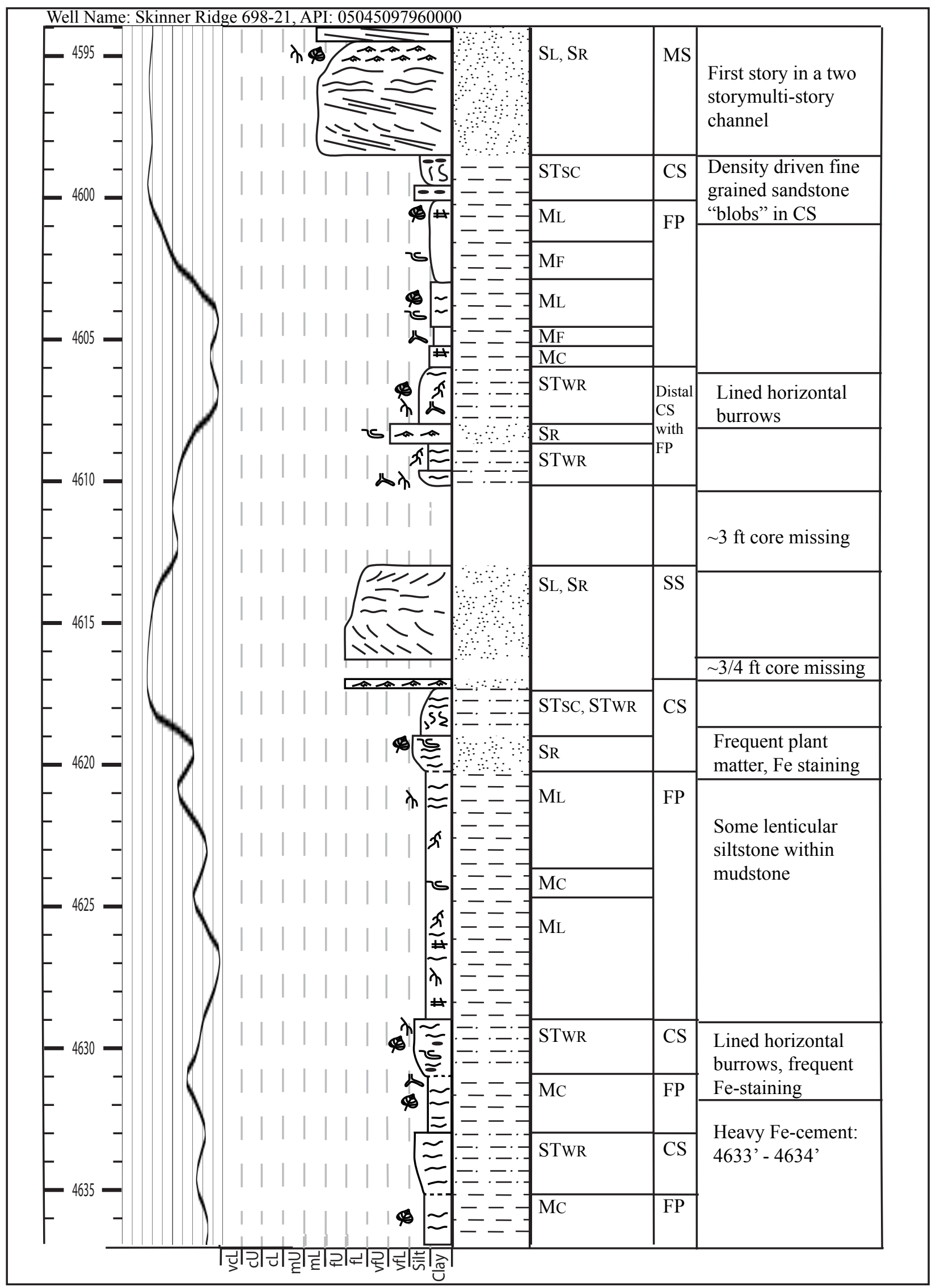




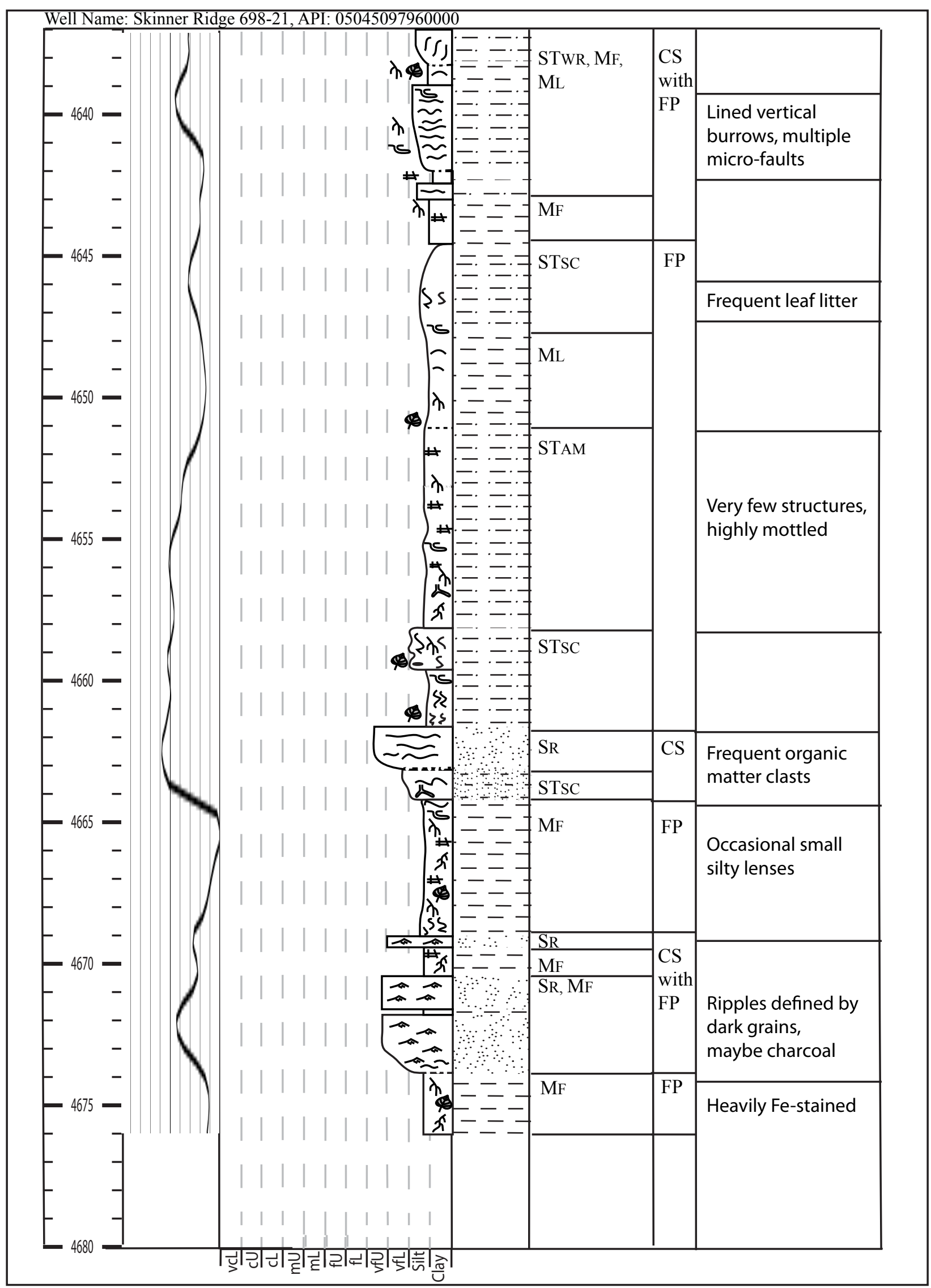




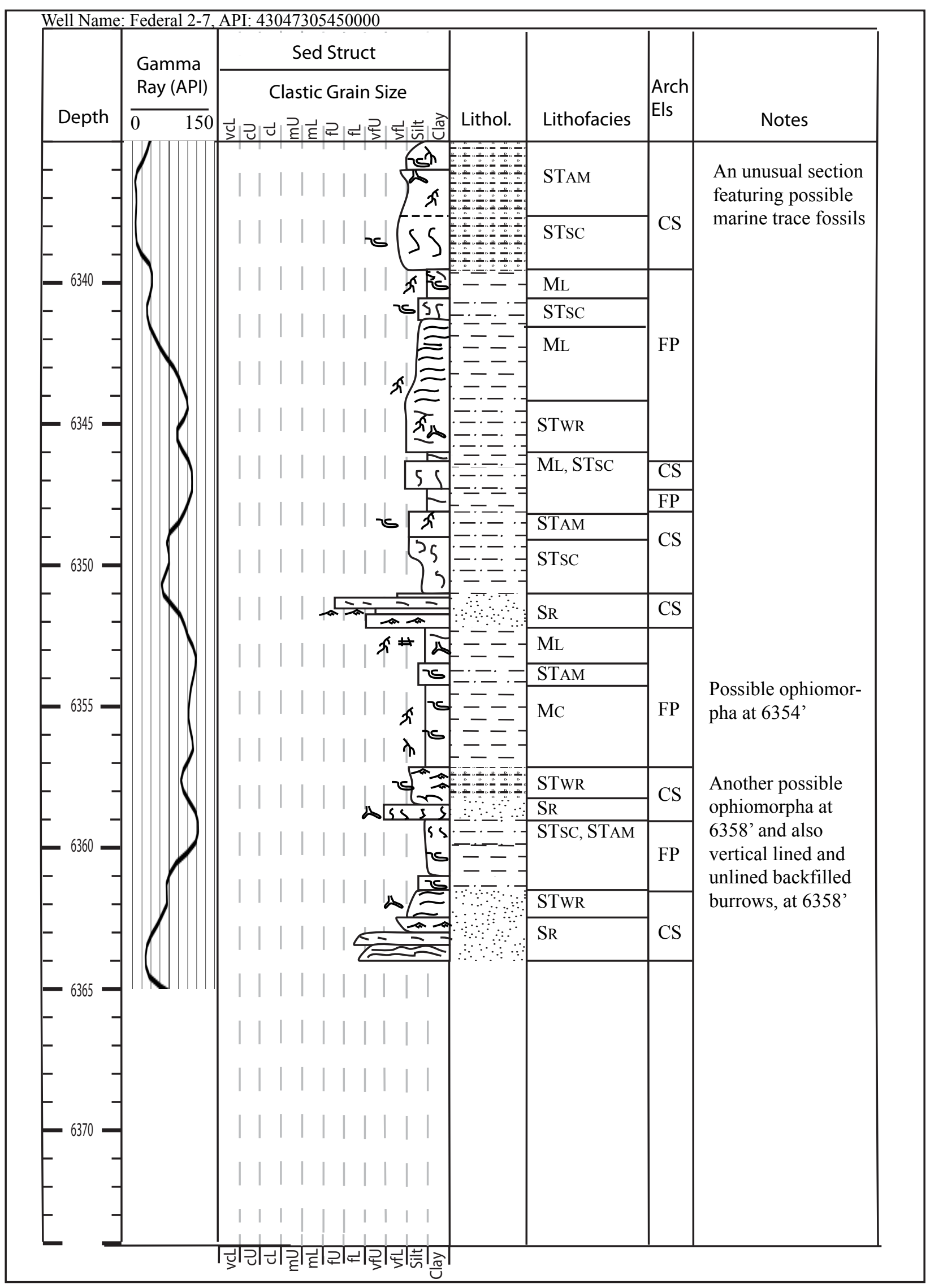




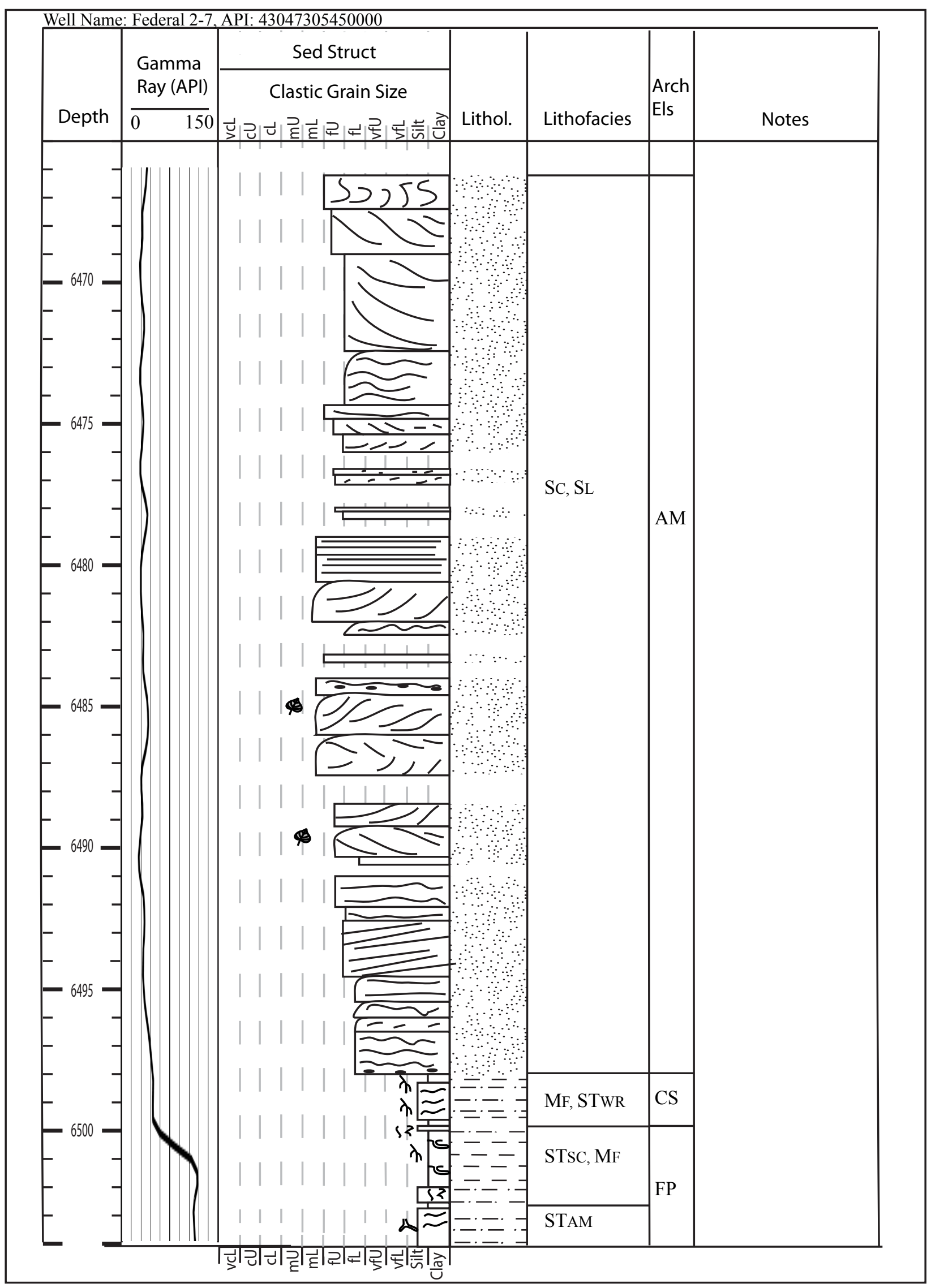




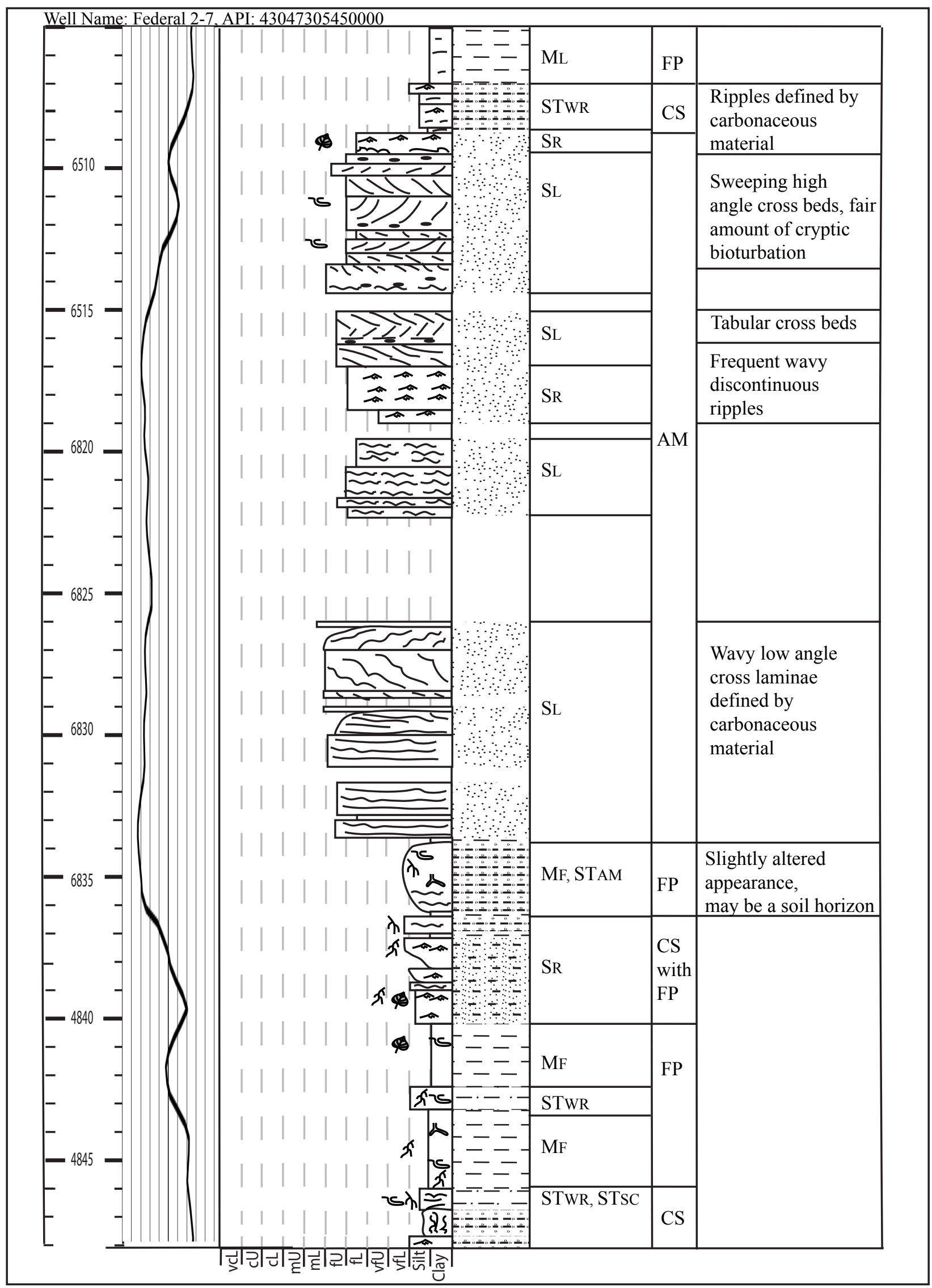




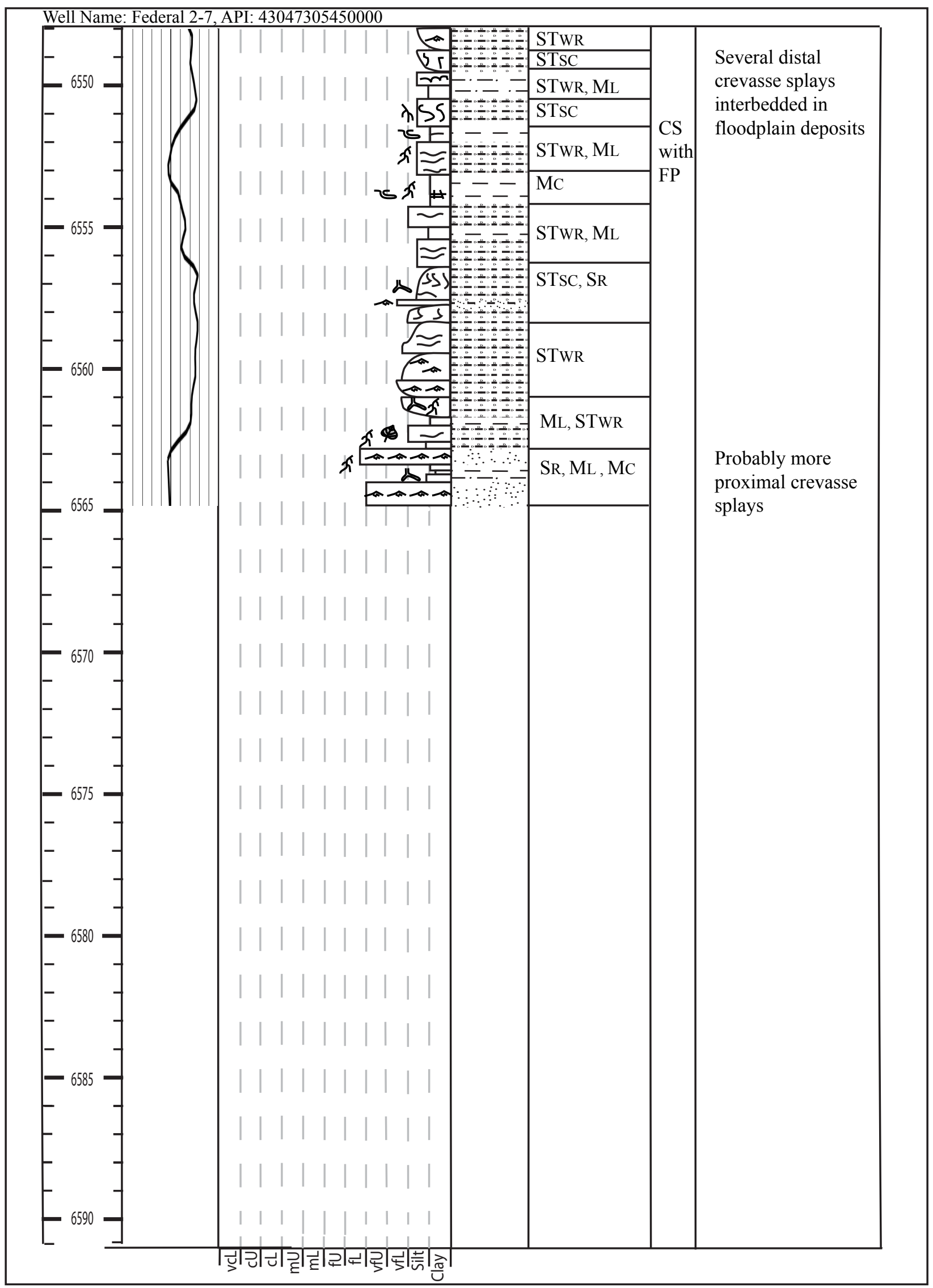




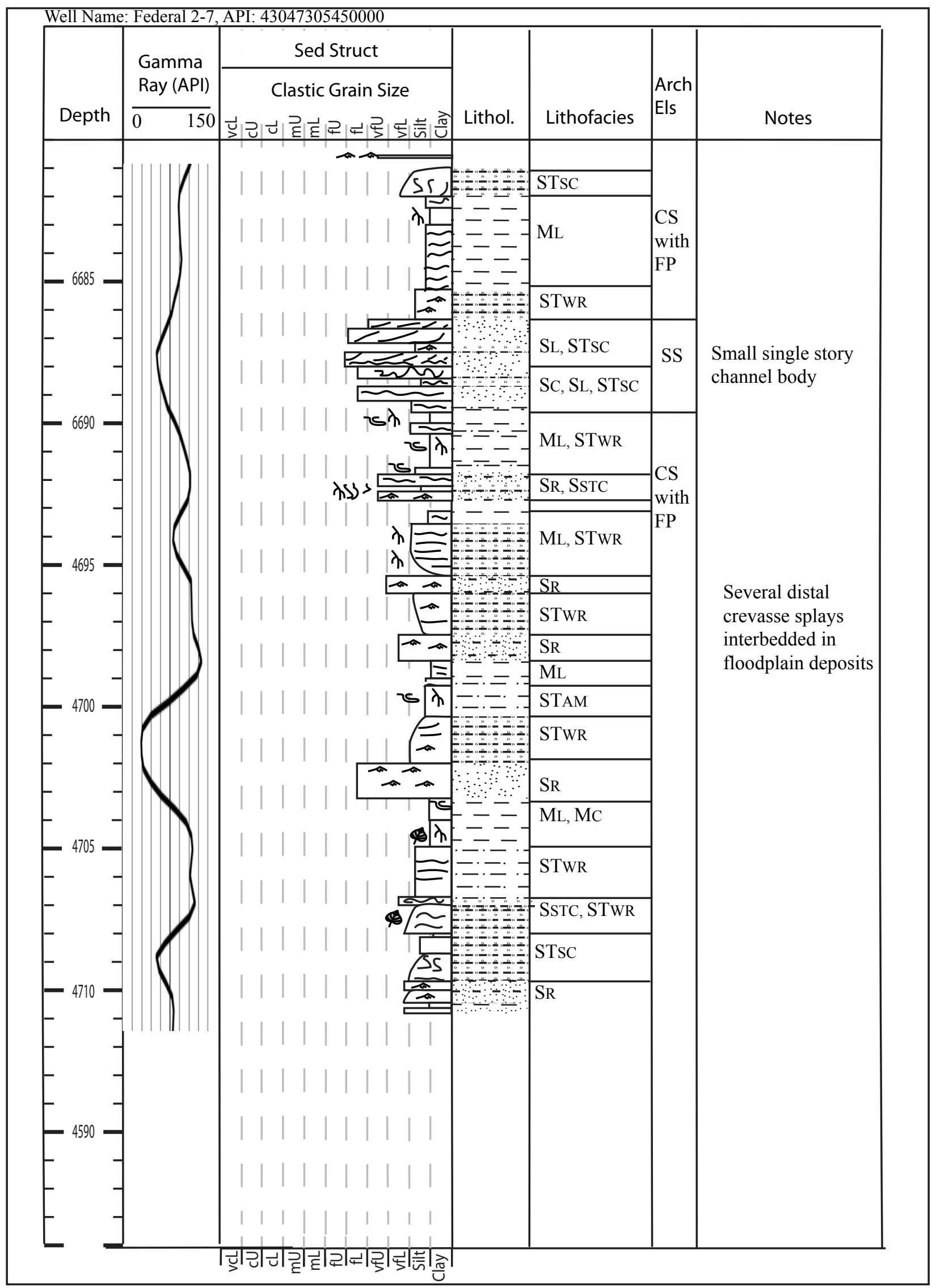




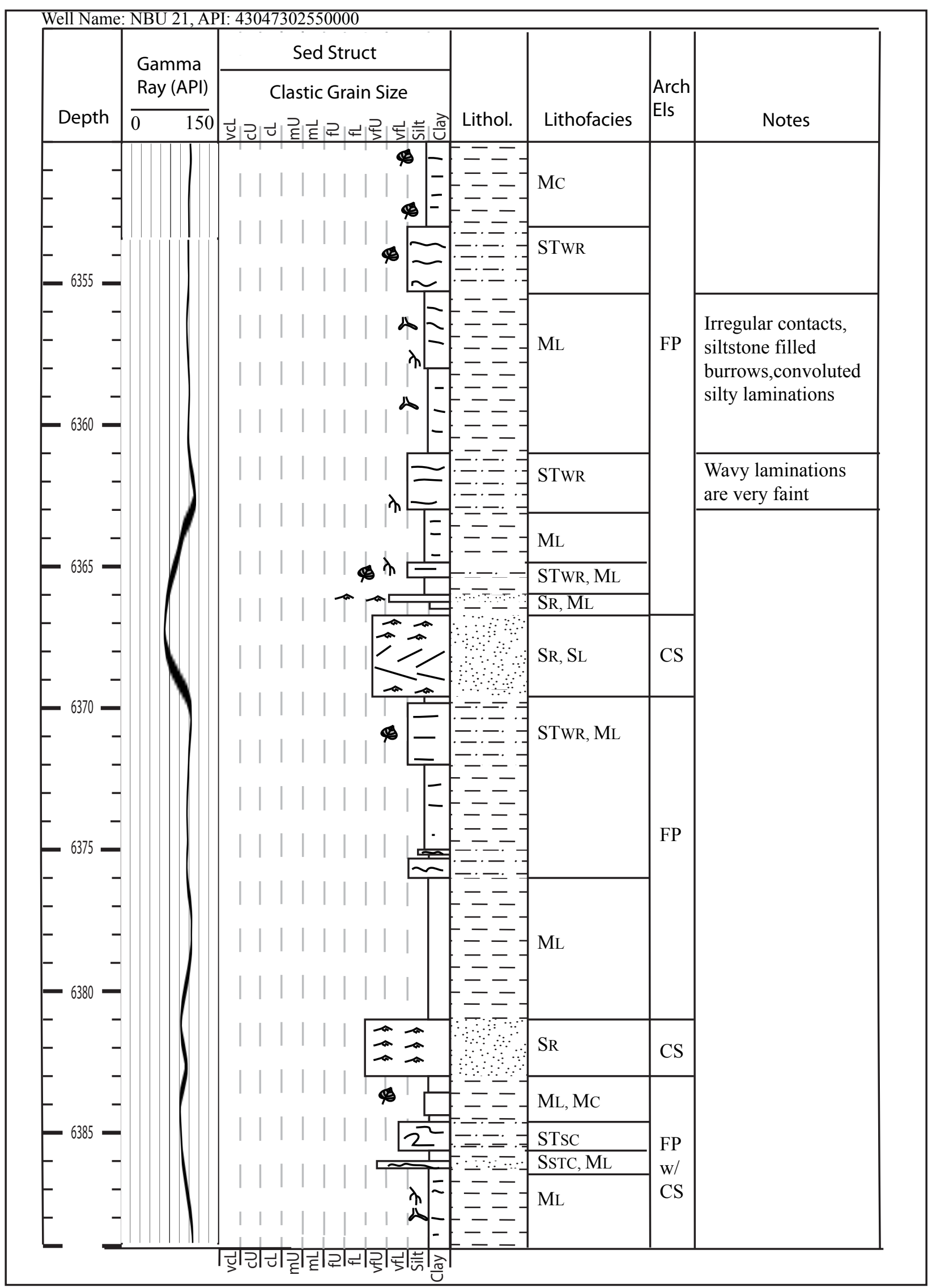




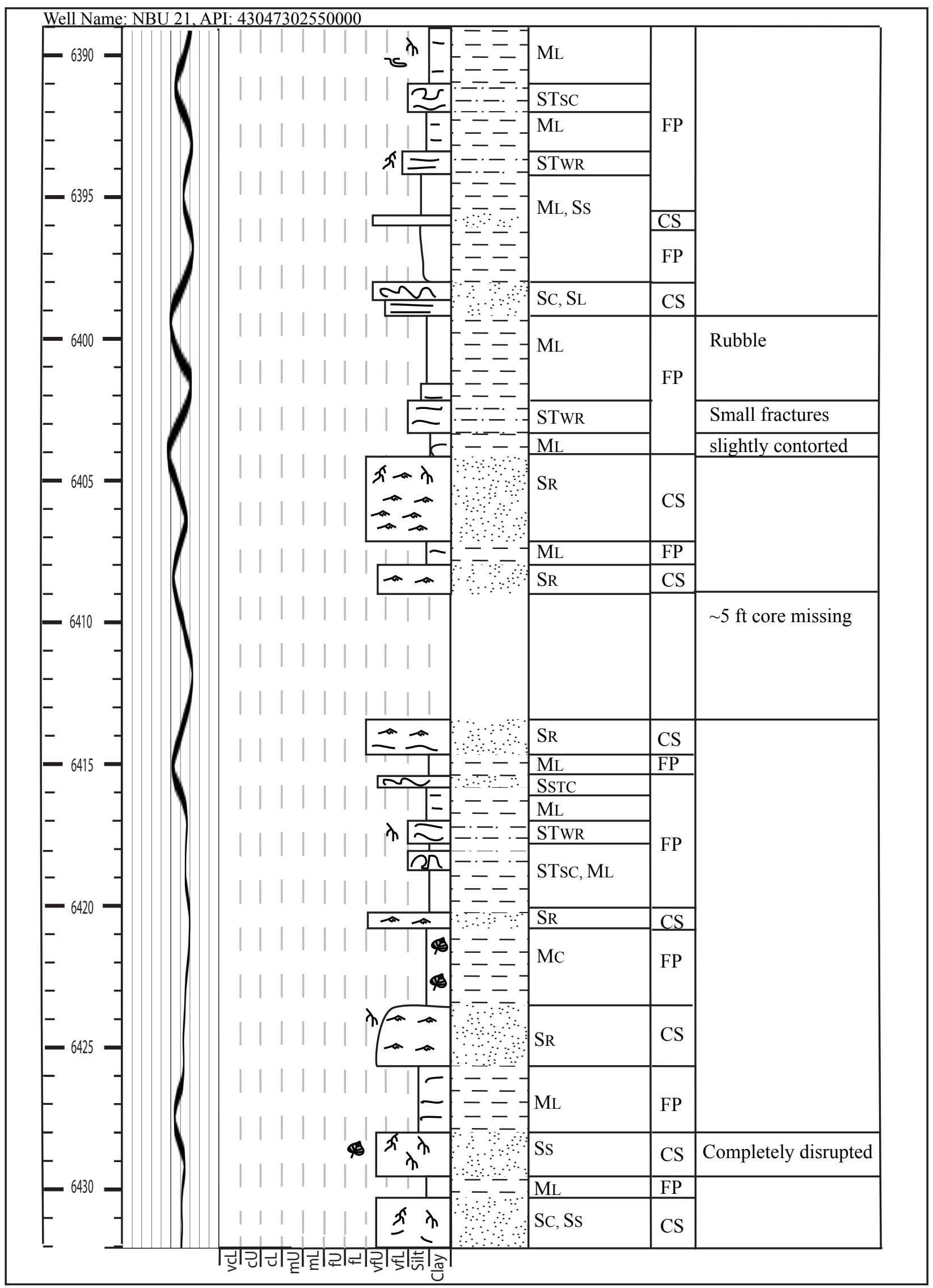




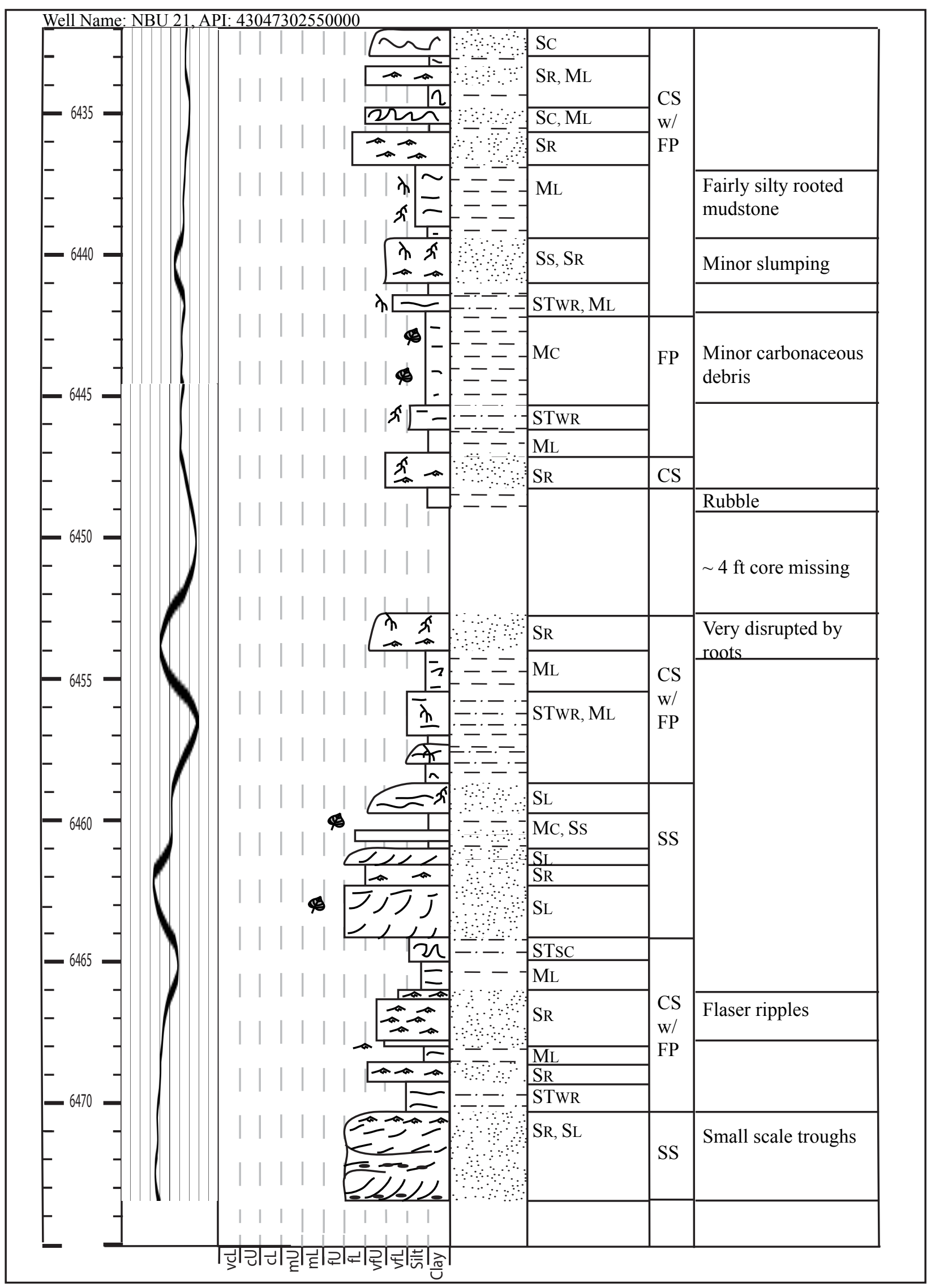




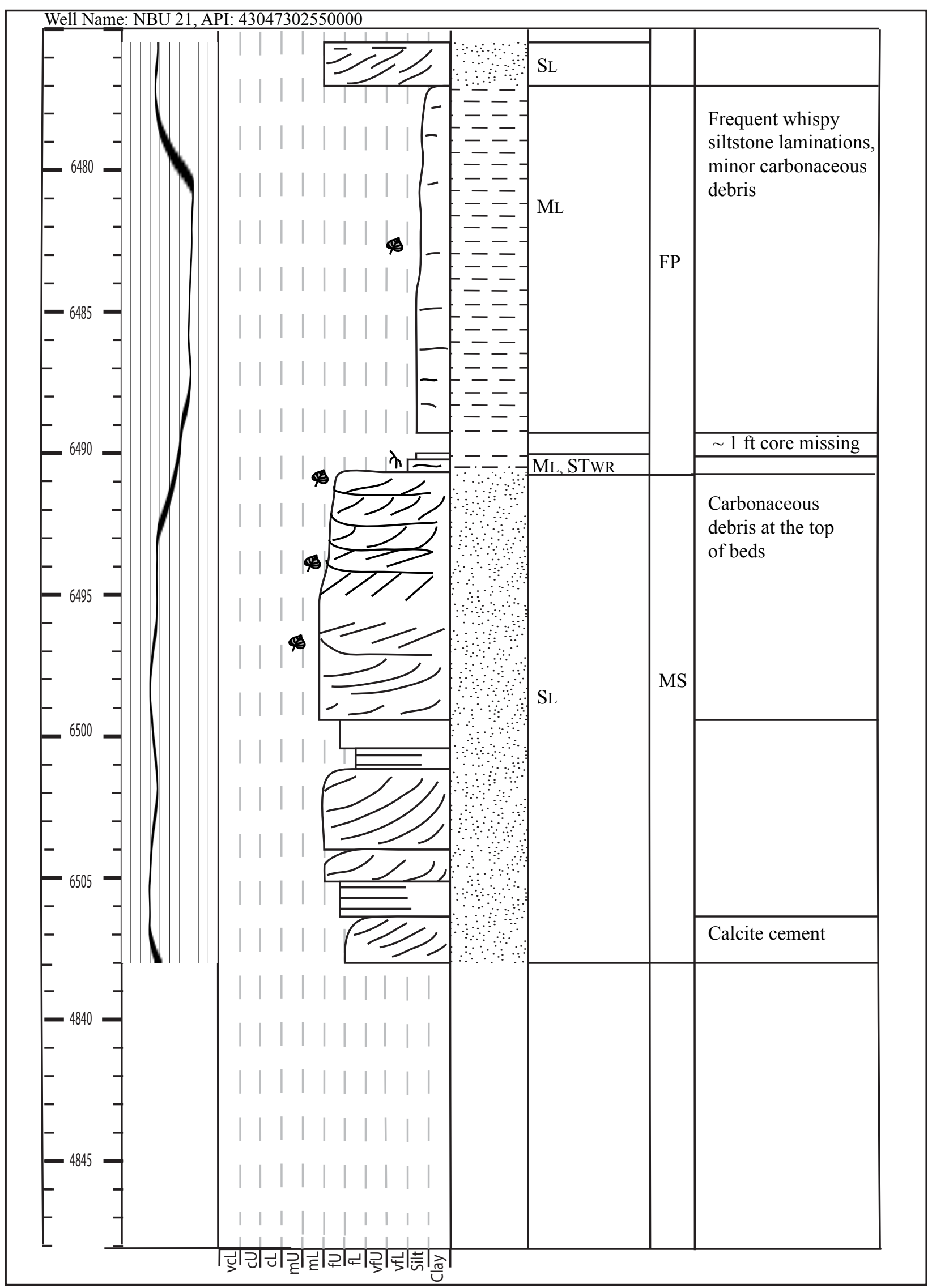




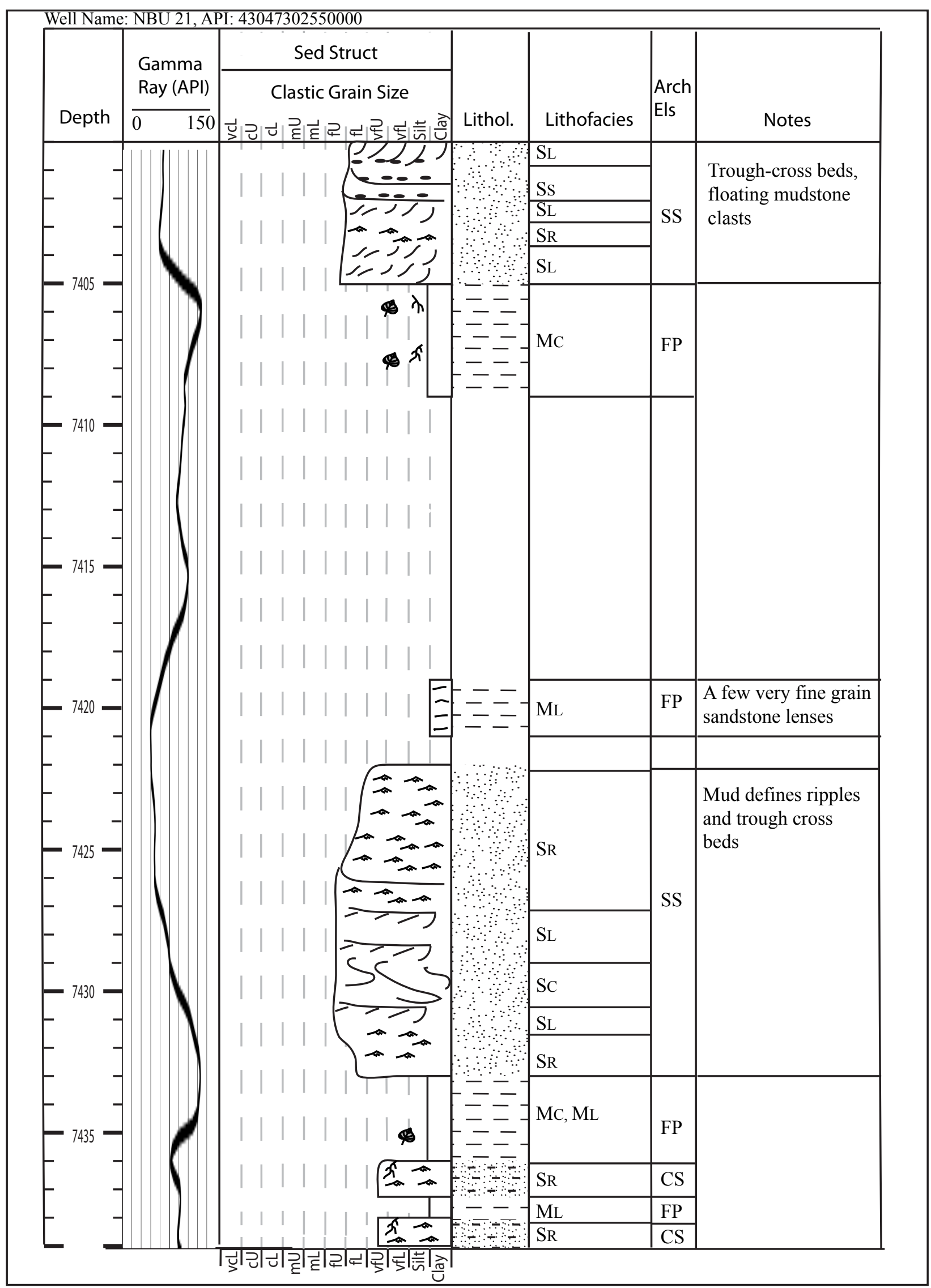




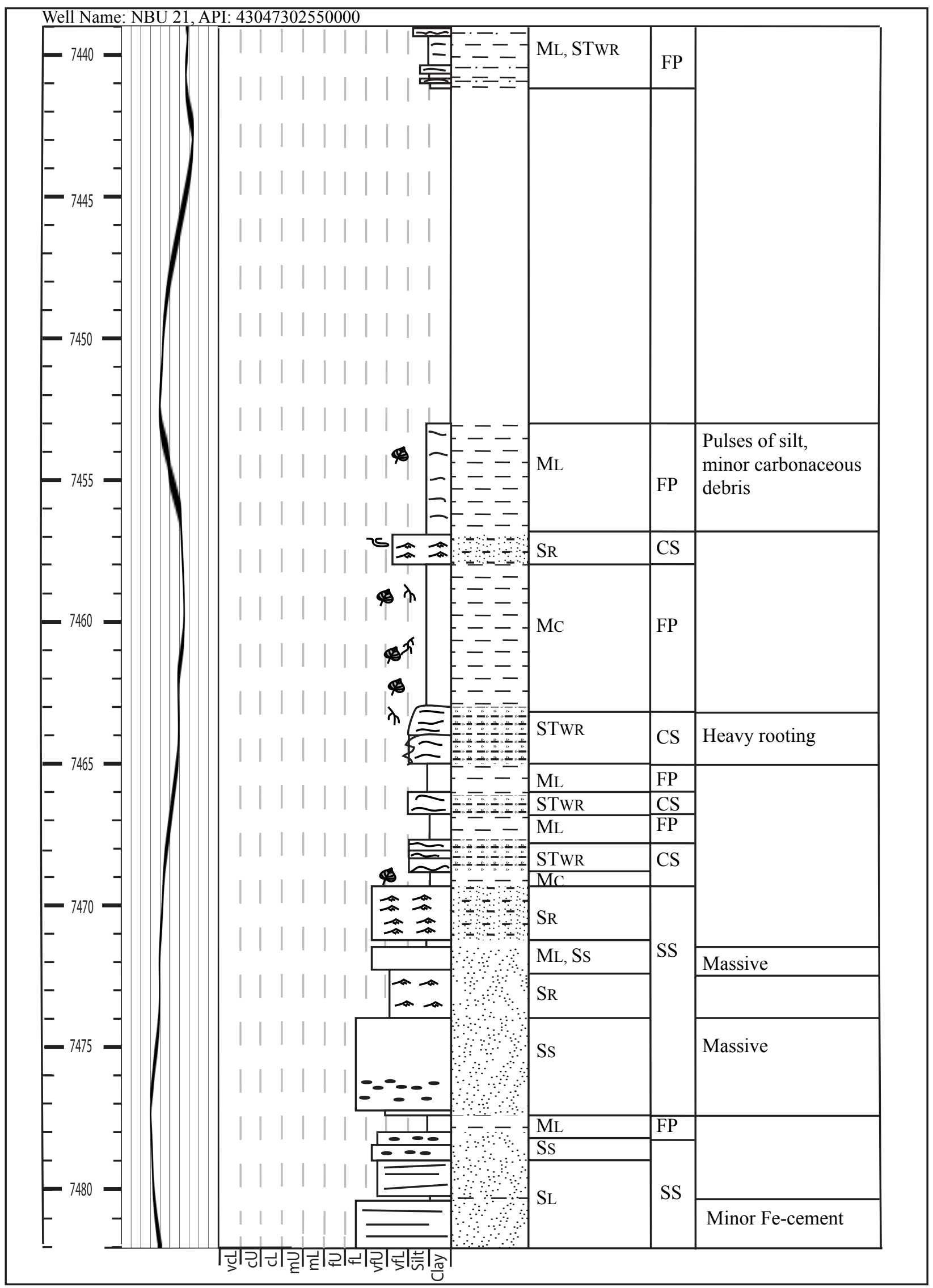




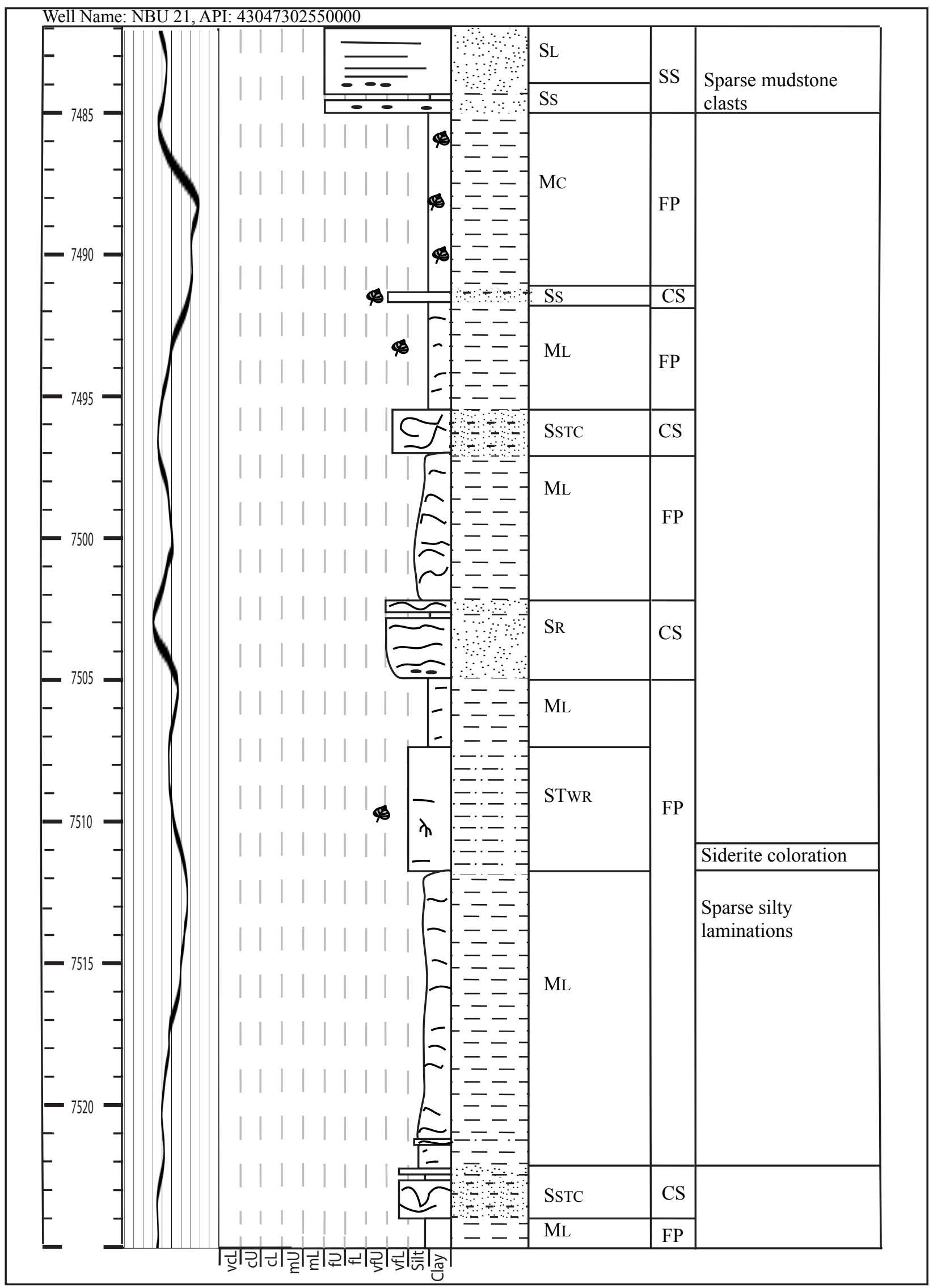




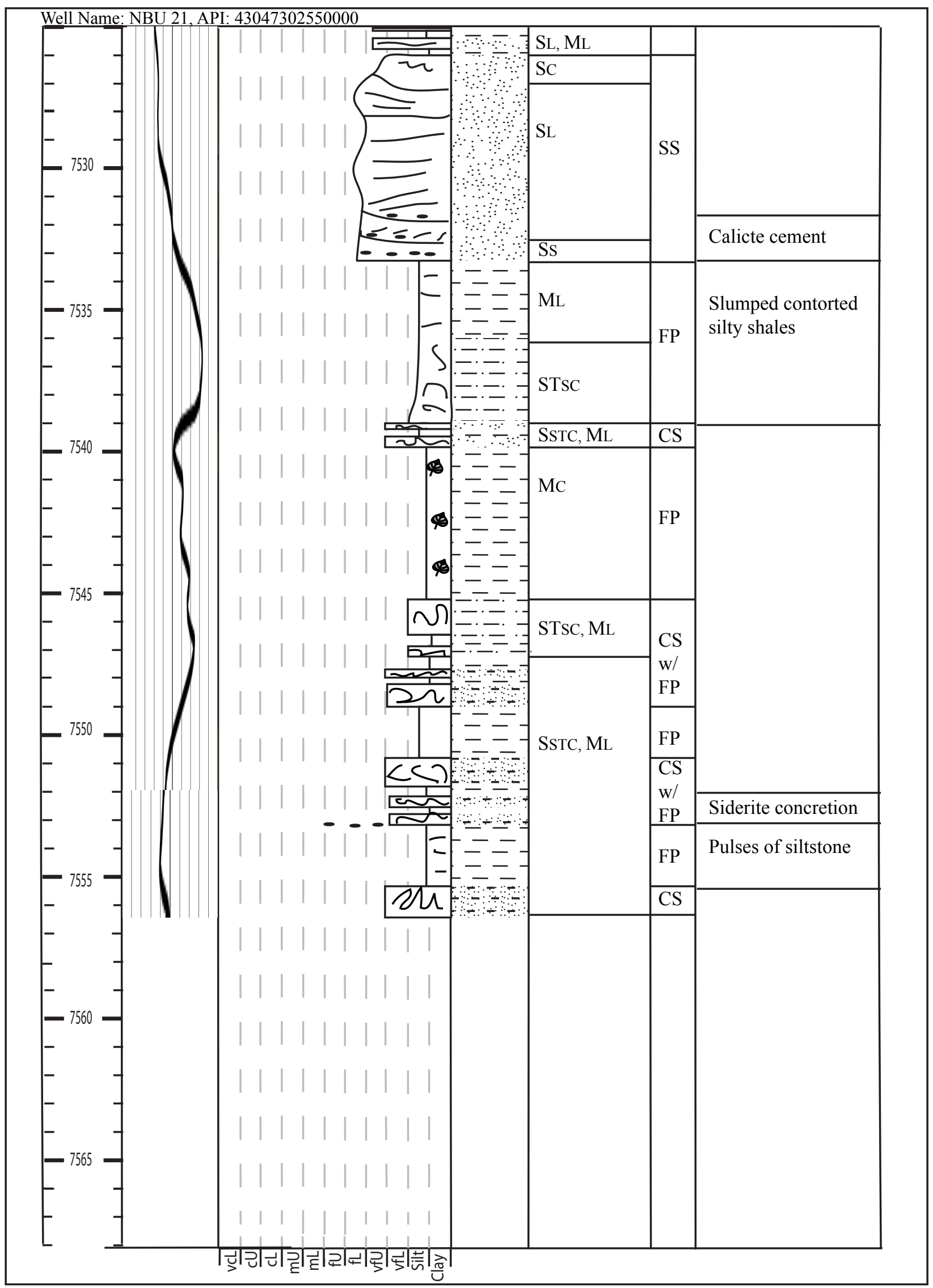




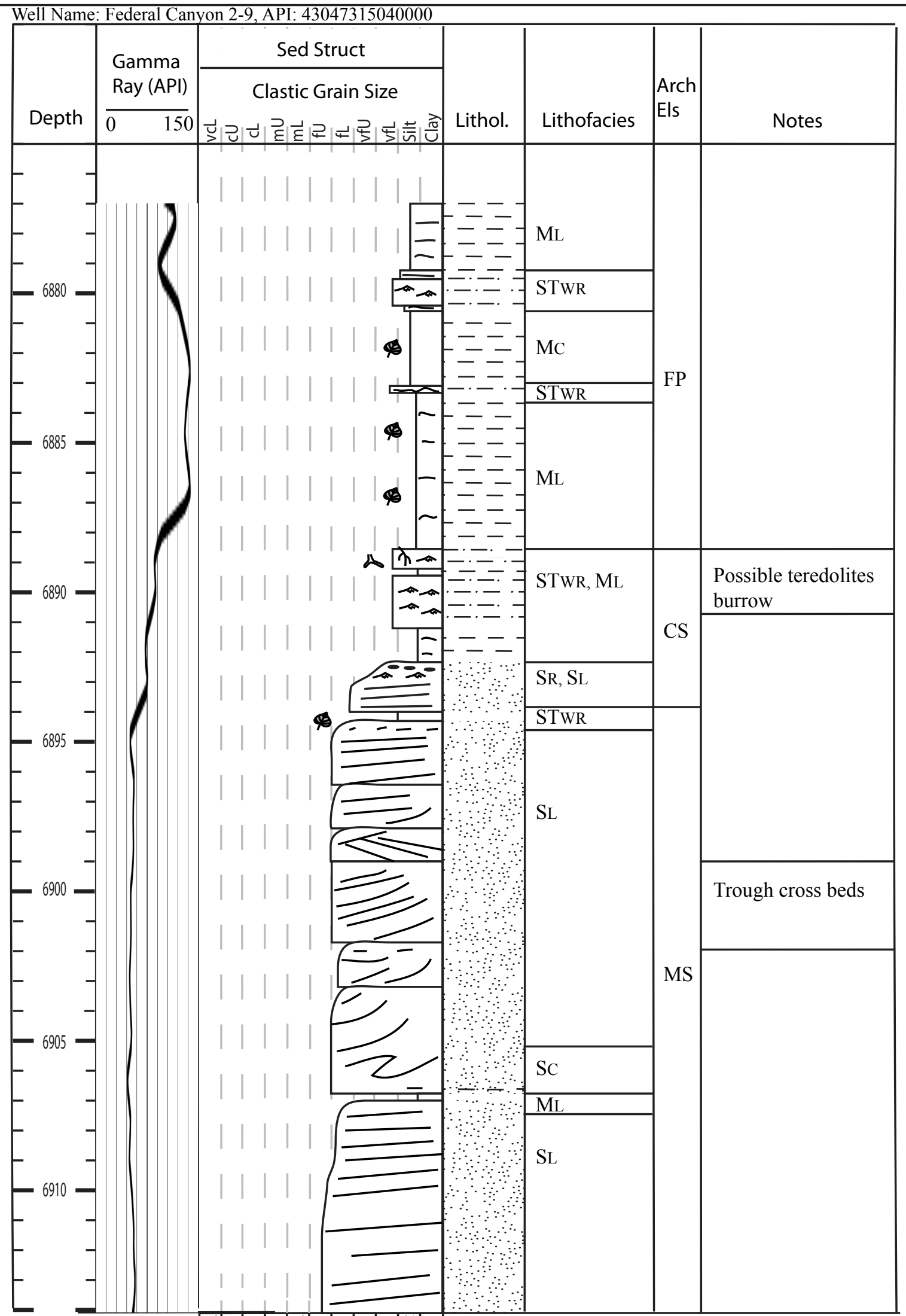

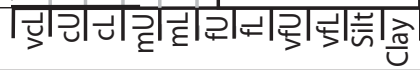




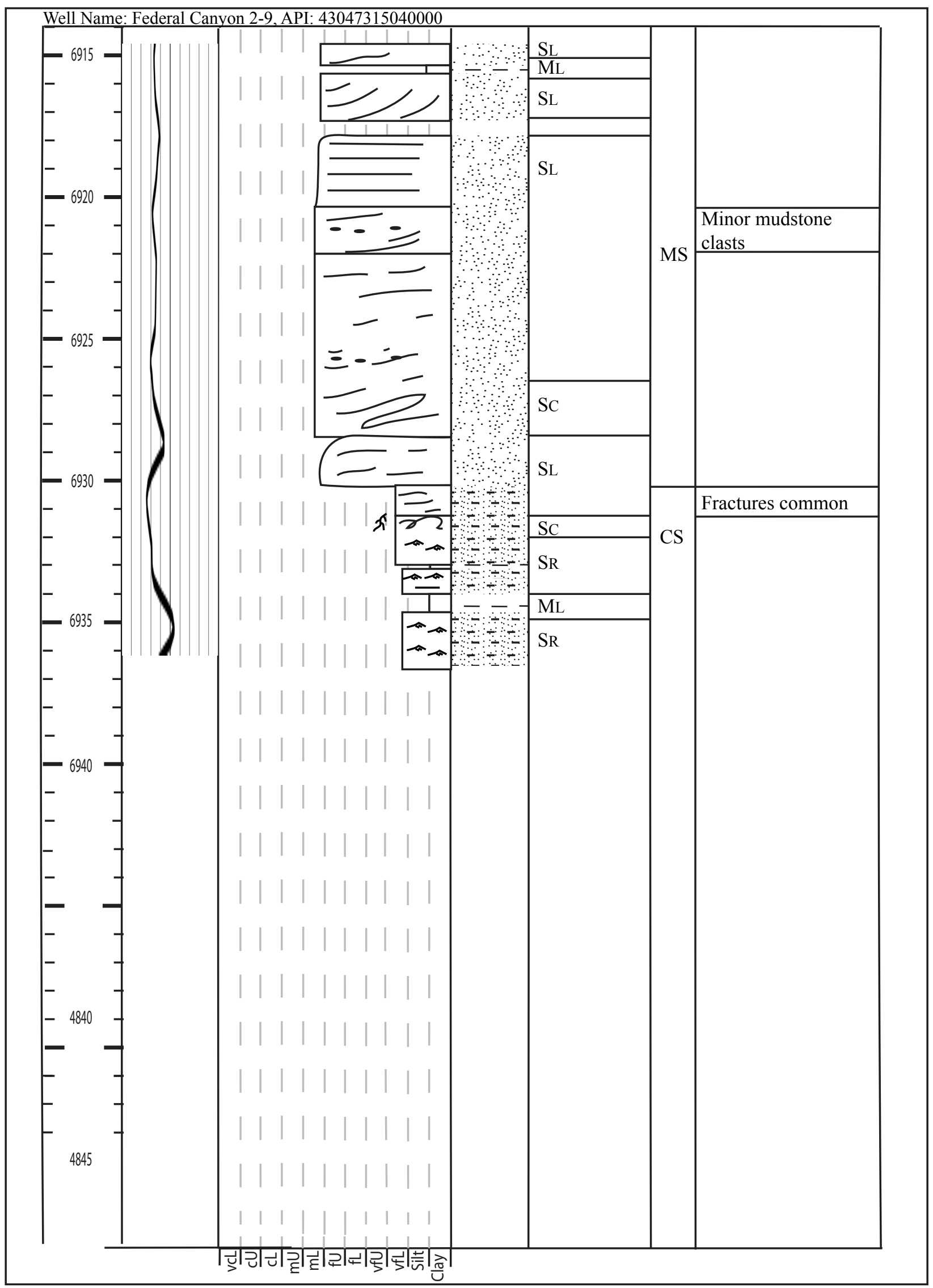




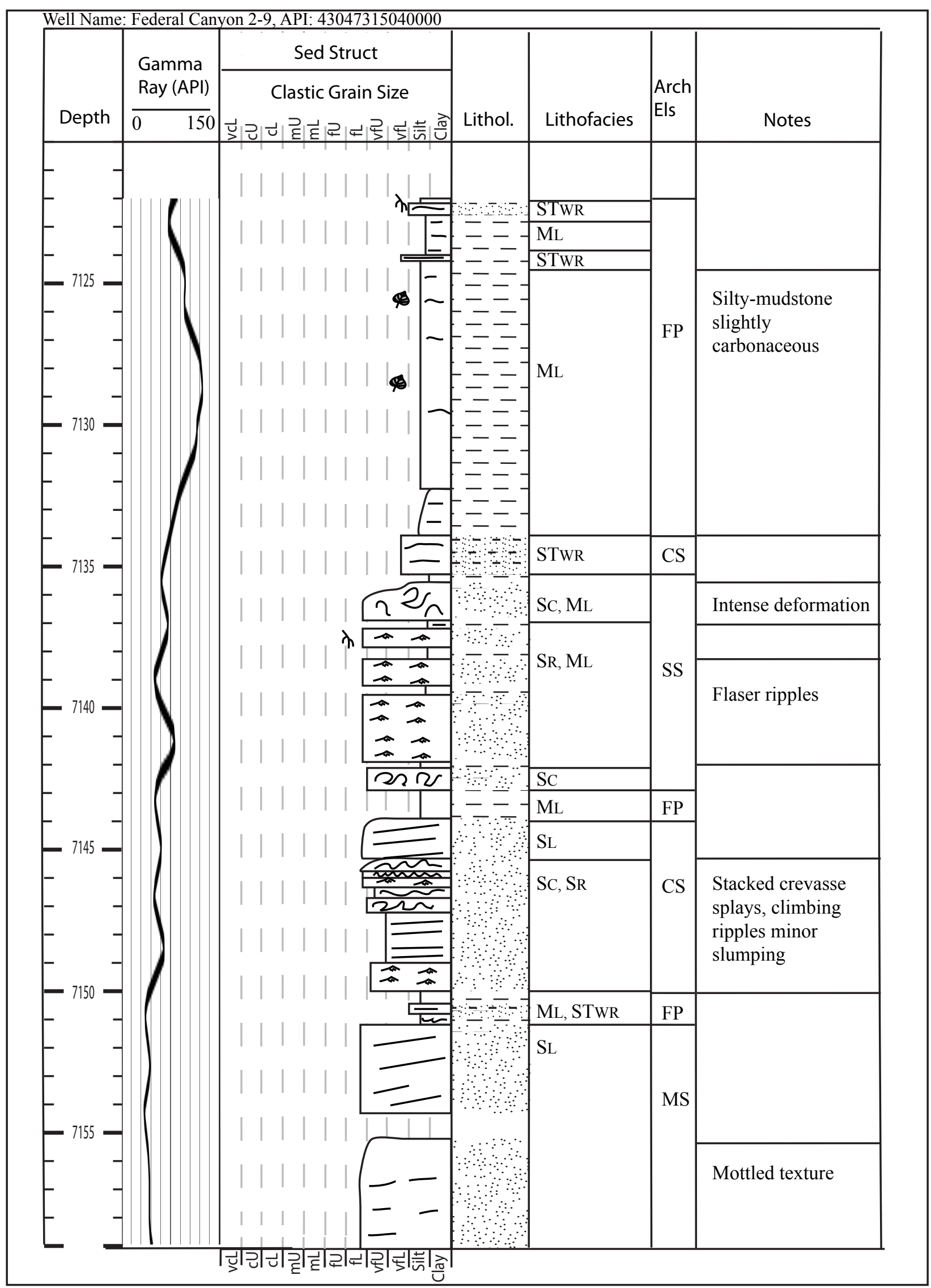




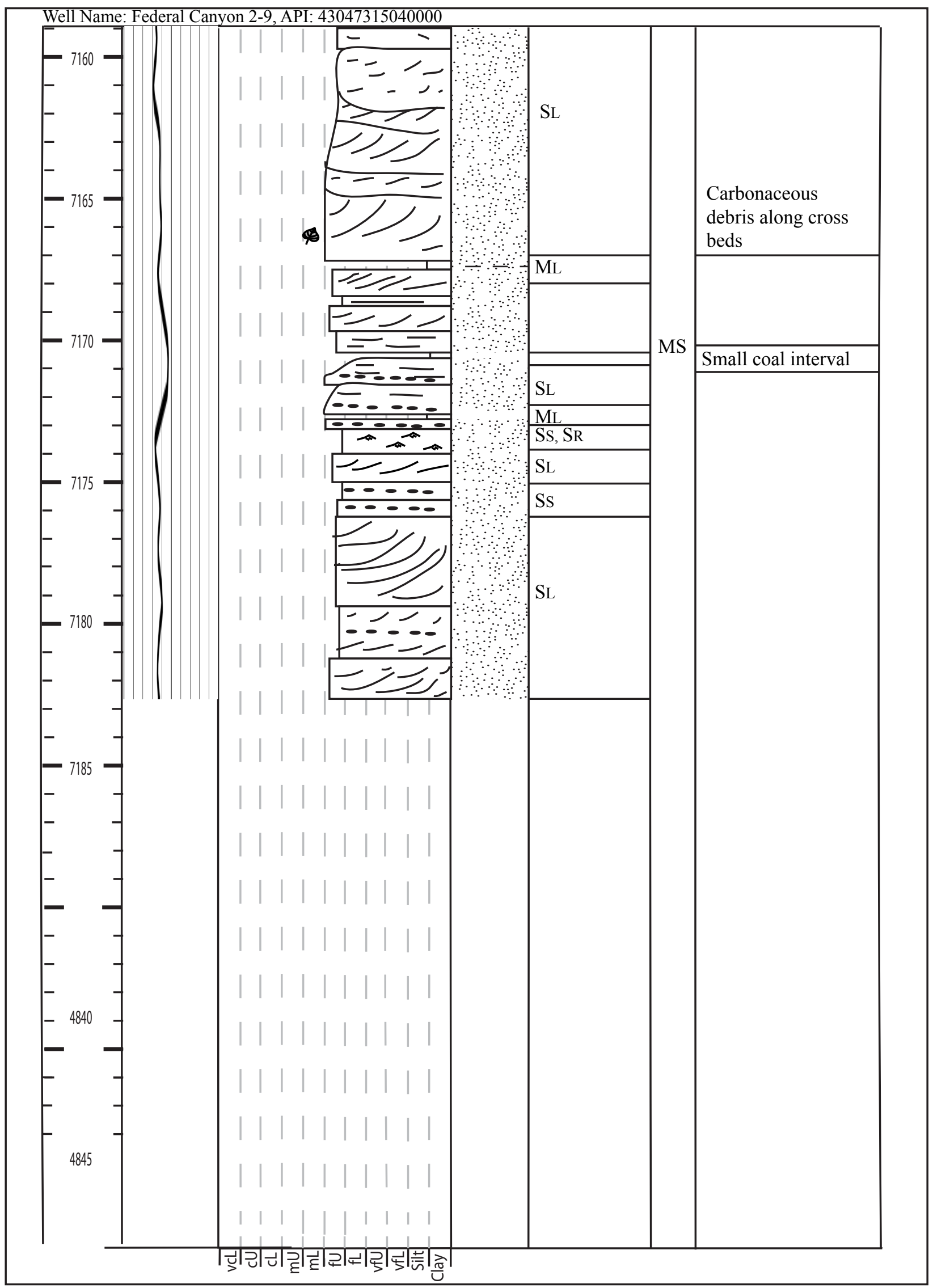




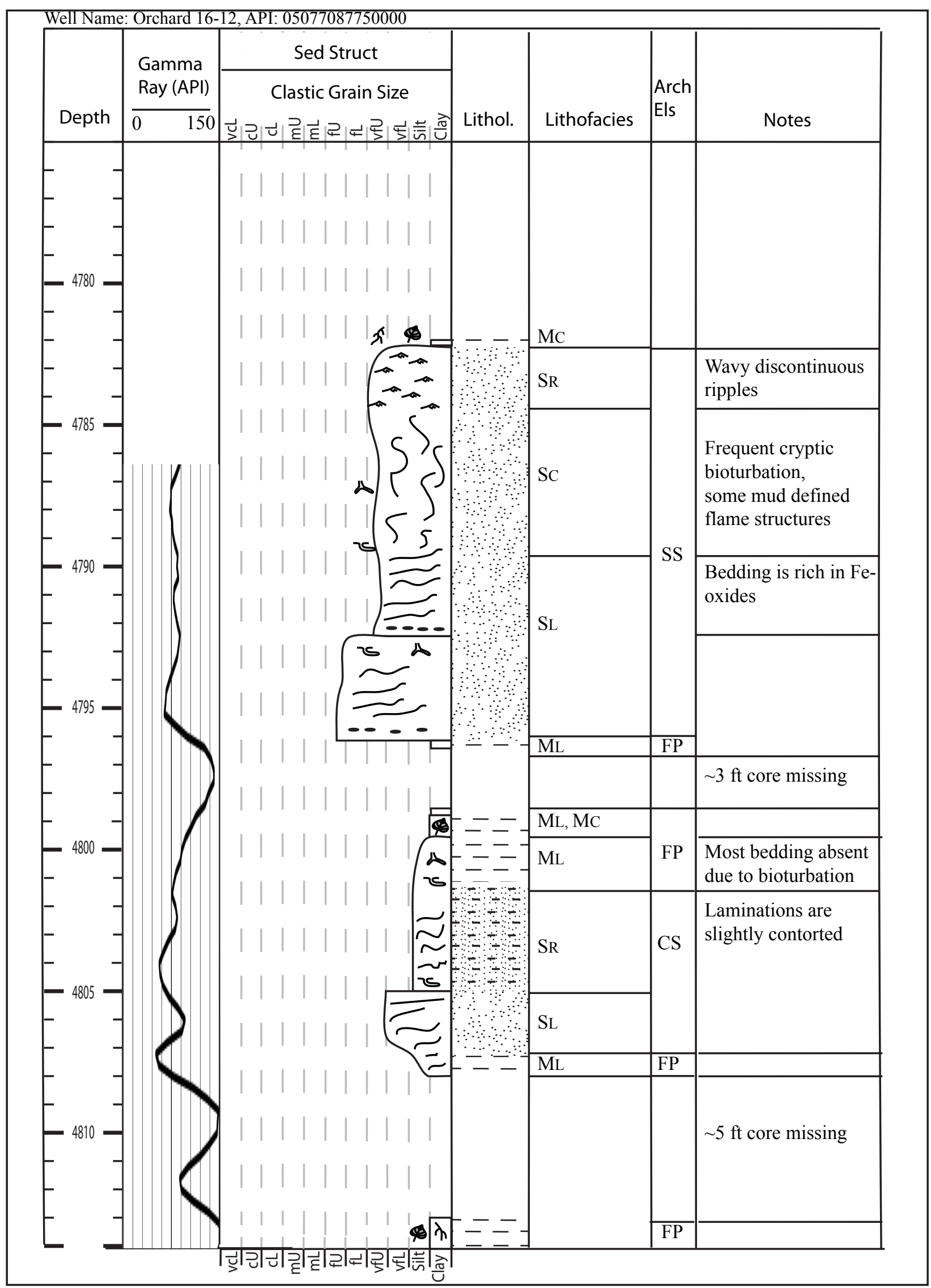




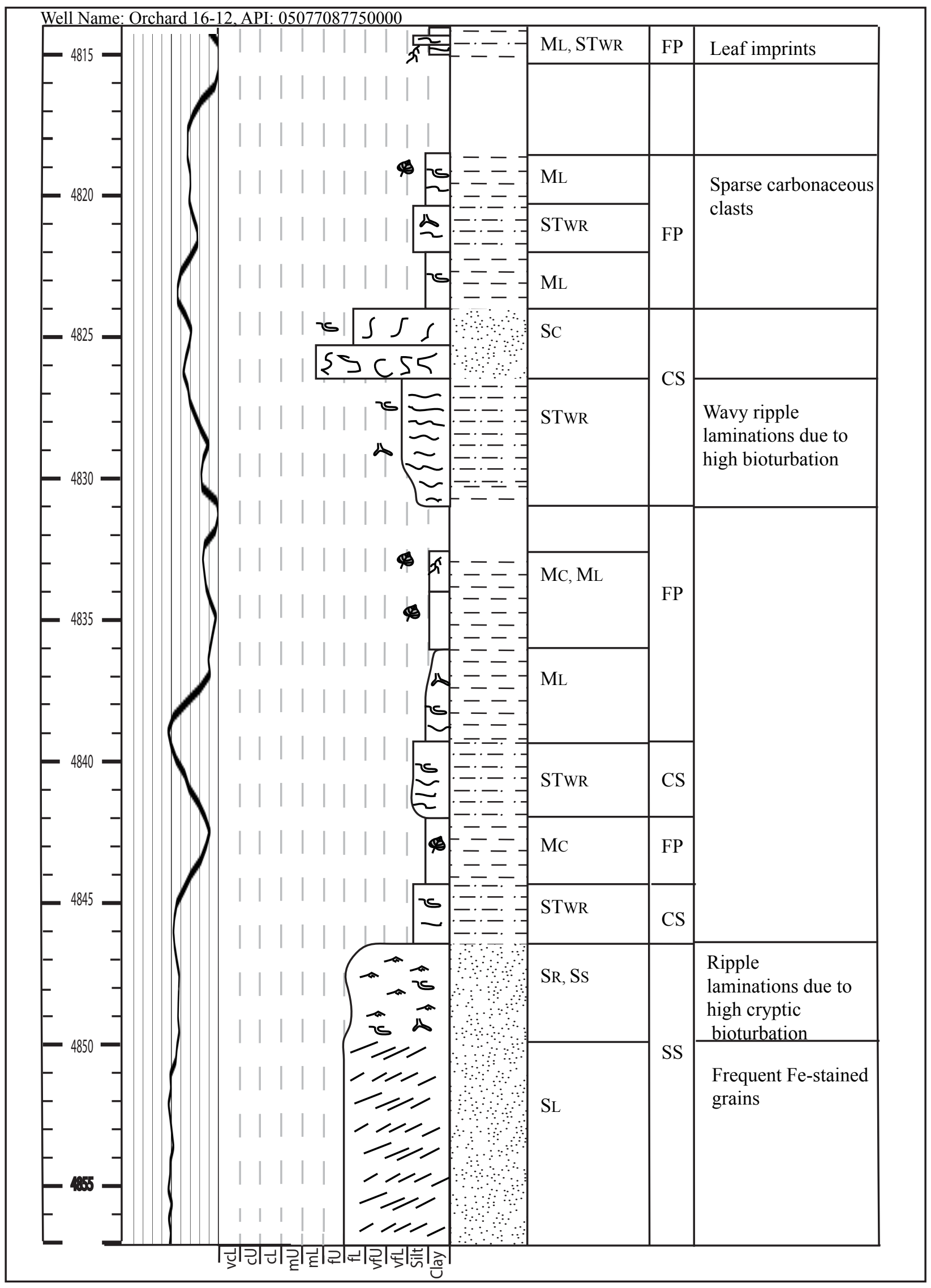




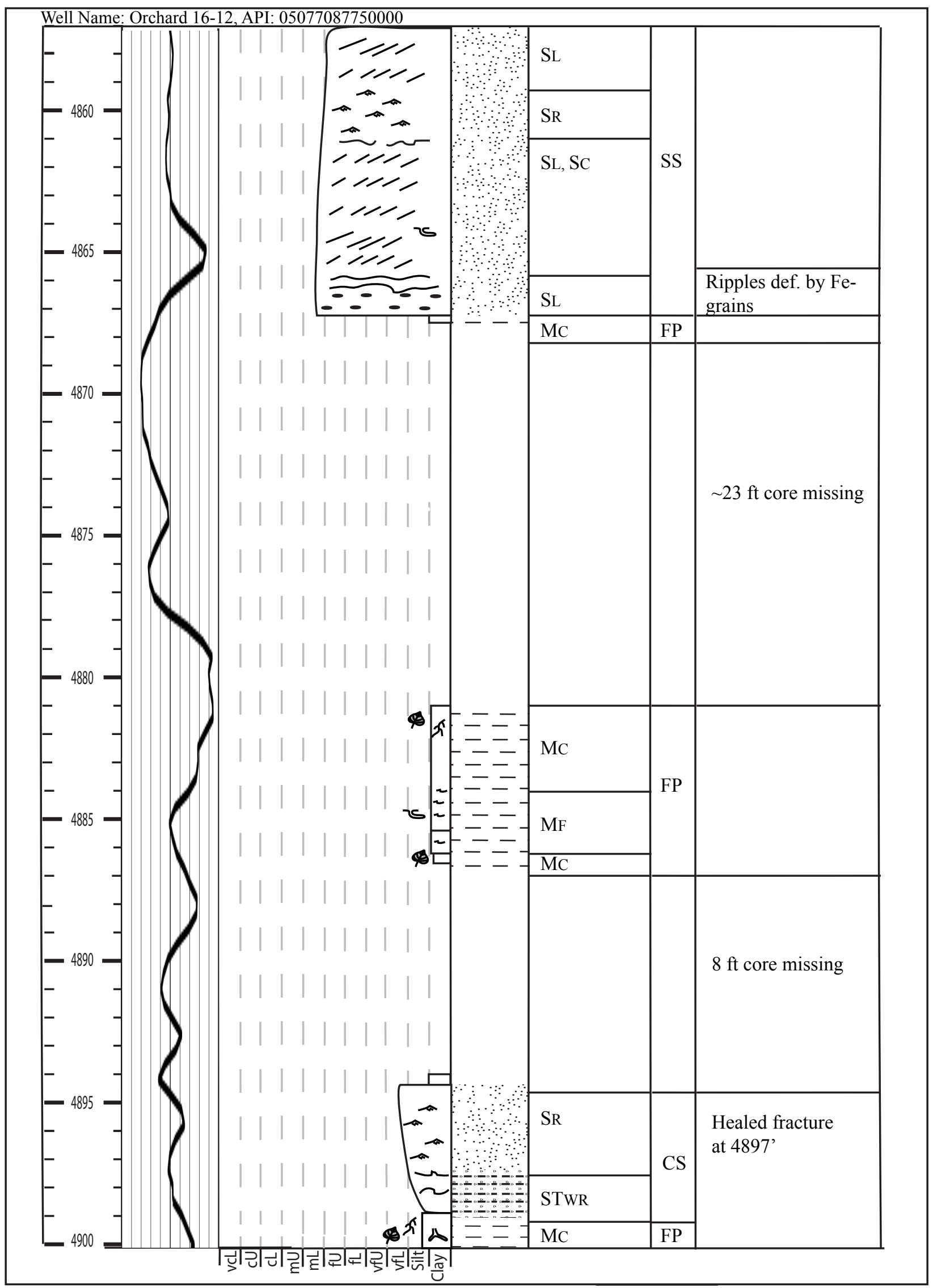




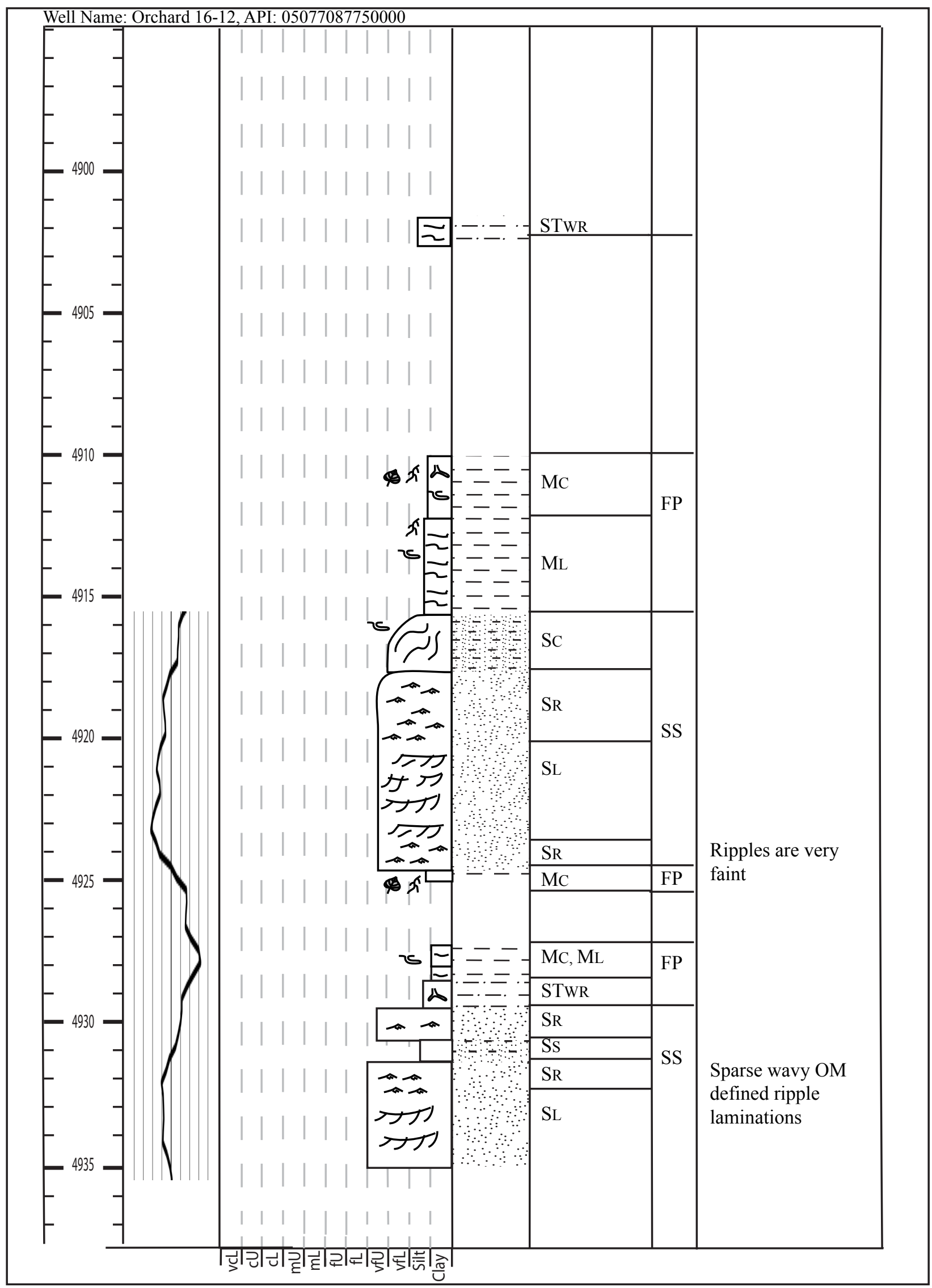




\section{Description of the Williams PA-424-34}

The description of the Williams PA-424-34 core was used with permission from (Keeton, 2012). Architectural elements noted in the following description are the same as those used in this study while the following similar facies are used: tabular, planar/tangential cross-stratified sandstone (Slp), trough cross-stratified sandstone (Slt), sructureless sandstone (Ss), slightly conglomeratic Sandstone (Sd), planar laminated sandstone (Sll), convoluted sandstone (Sc), ripple cross-

laminated sandstone (Srs), featureless silstone (Fs), convoluted mudrock with sandstone (CMs), and convoluted sandstone with mudrock $(\mathrm{CSm})$. 


\section{Stratification}

$[\because \because, \quad$ Structureless

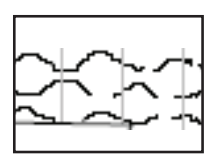

Wavy Lamination

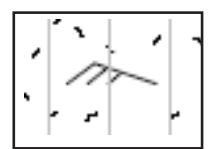

Ripple Stratification

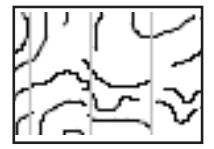

Convoluted Bedding

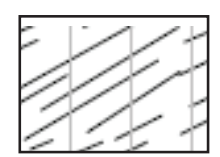

High-angle

Cross-stratification

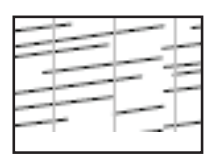

Low-angle

Cross-stratification

Planar Laminated

\section{Lithology and Features}
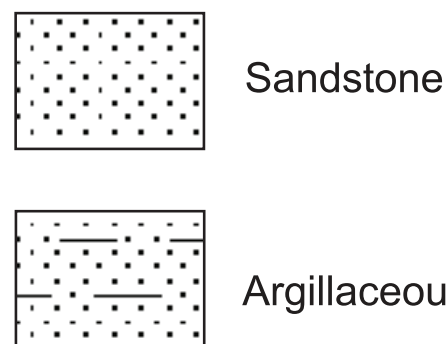

Argillaceous Sandstone

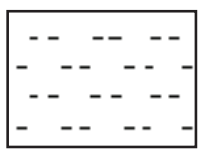

Claystone

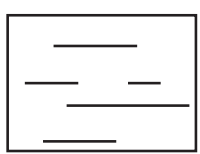

Mudstone

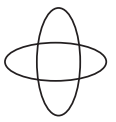

Bioturbation

$\lessdot \quad$ Mudrock chips

PY Pyrite

CA Calcite 


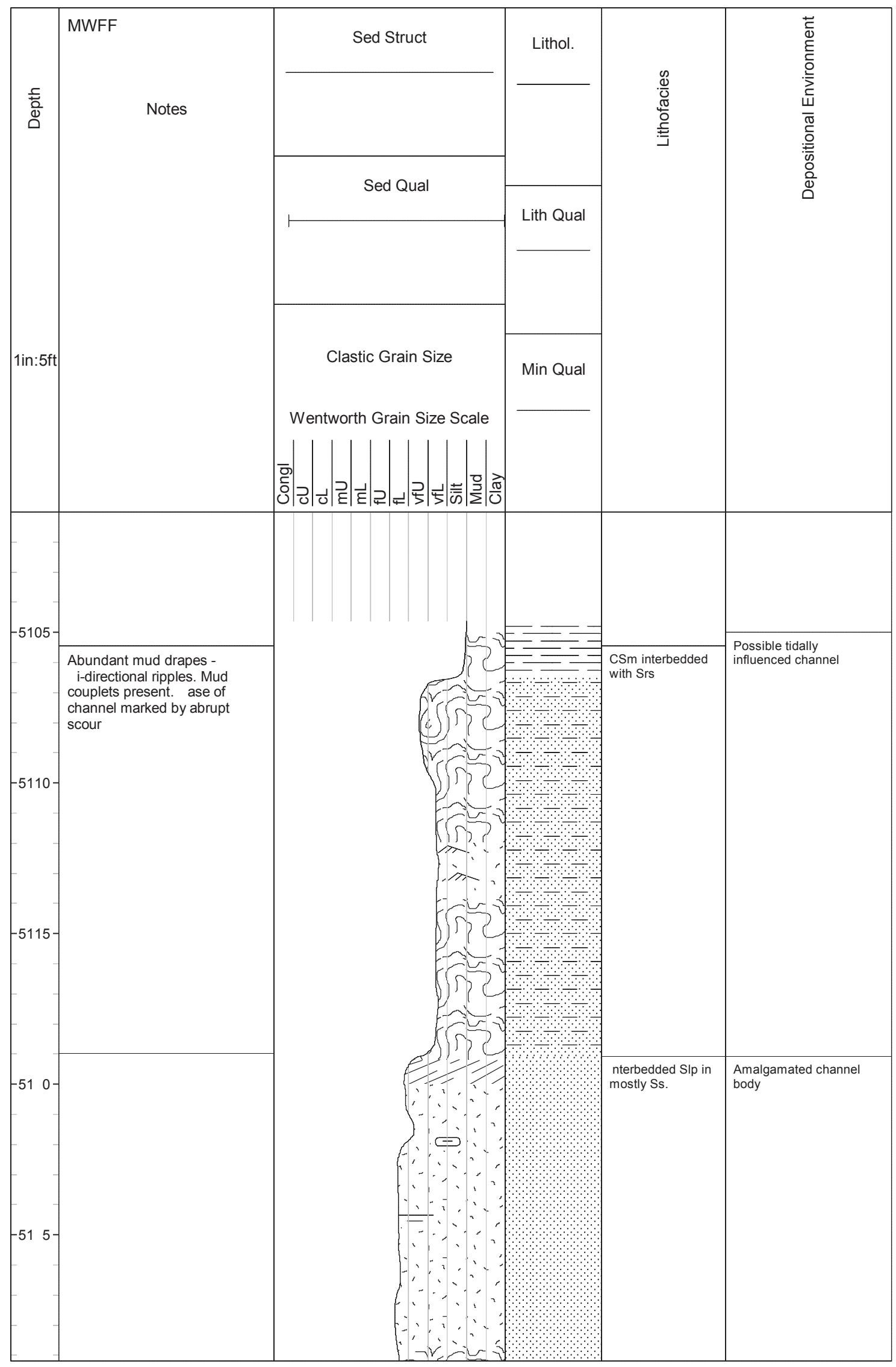




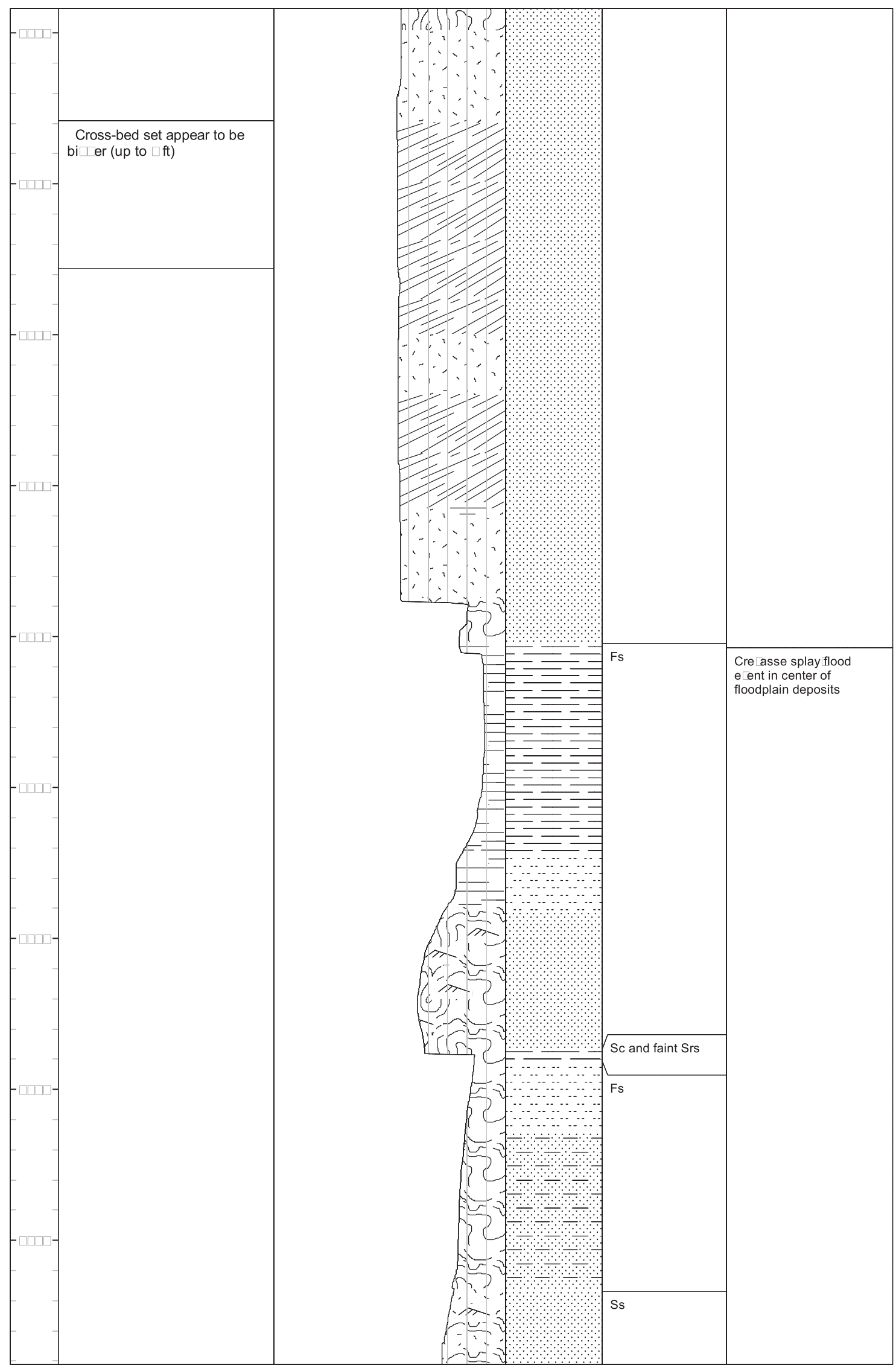




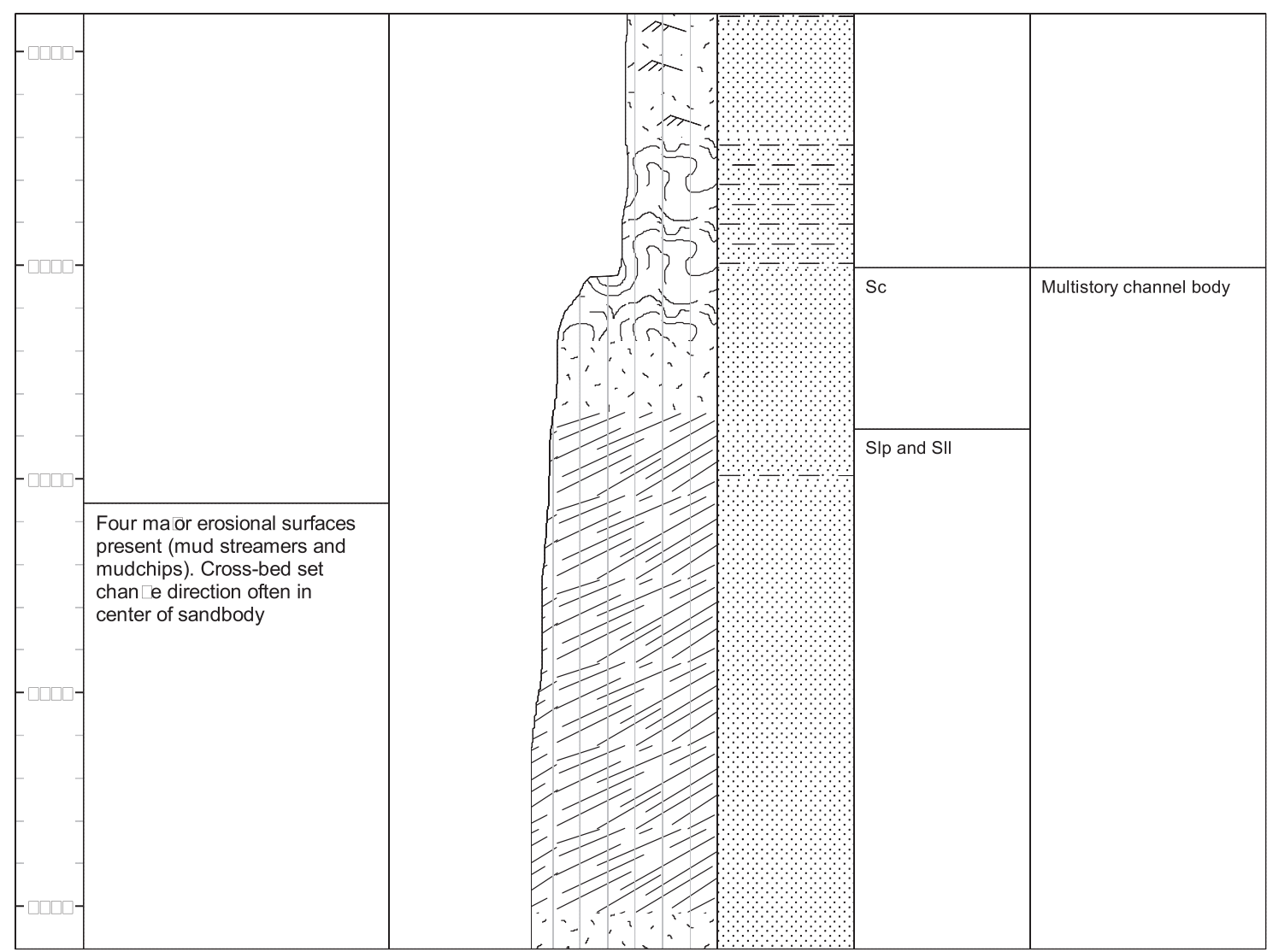




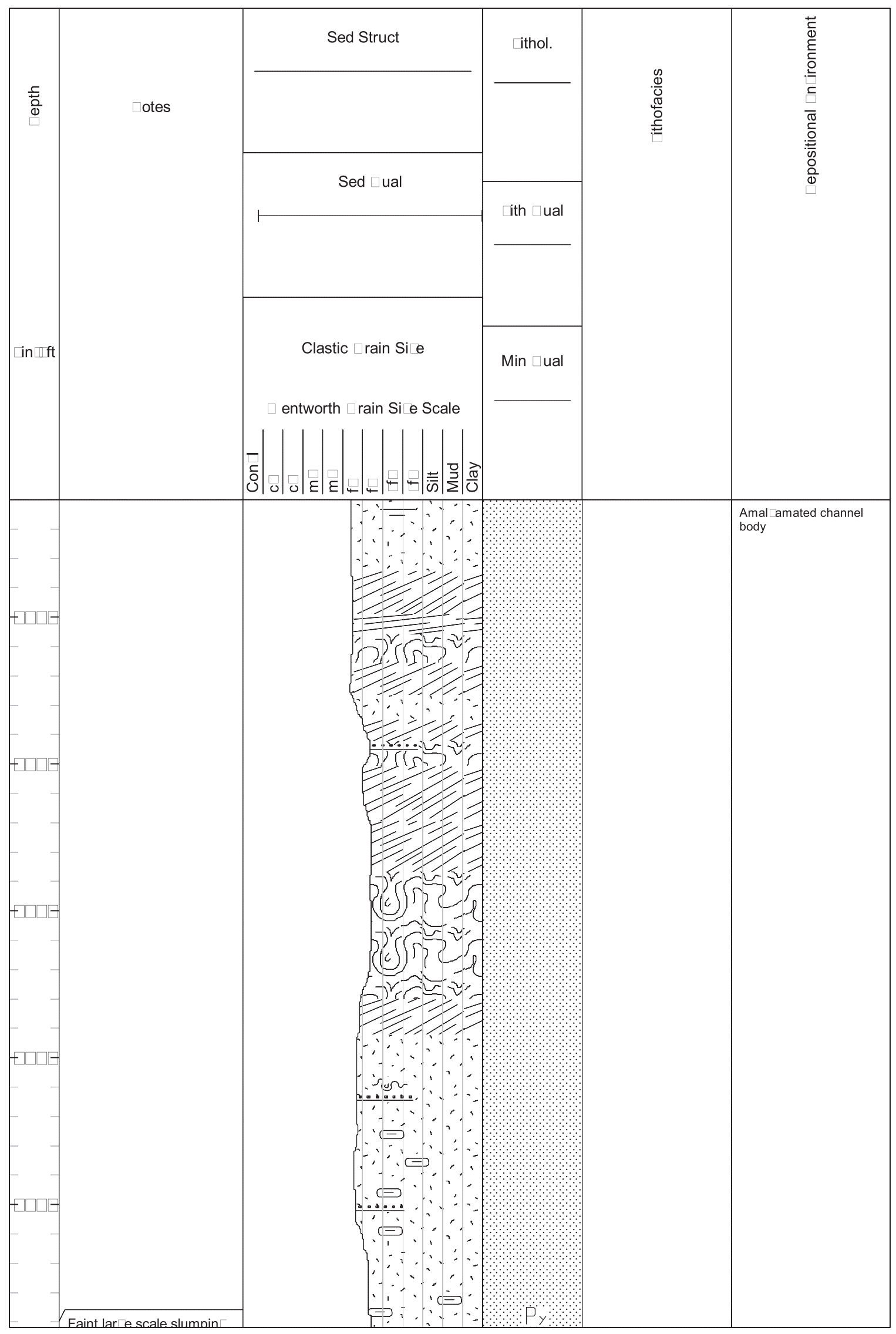




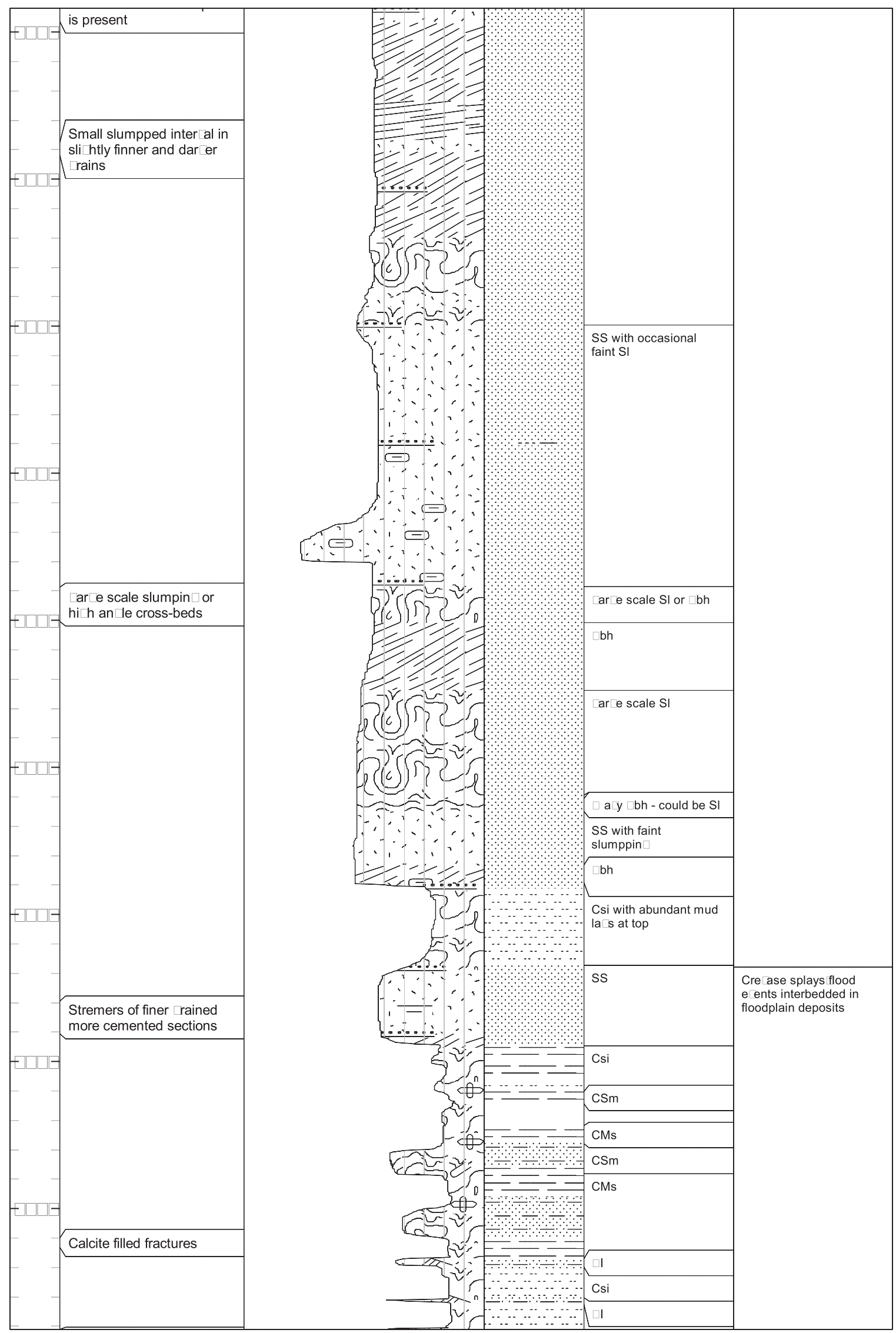




Mostly structureless but
sith faint cross-beds and




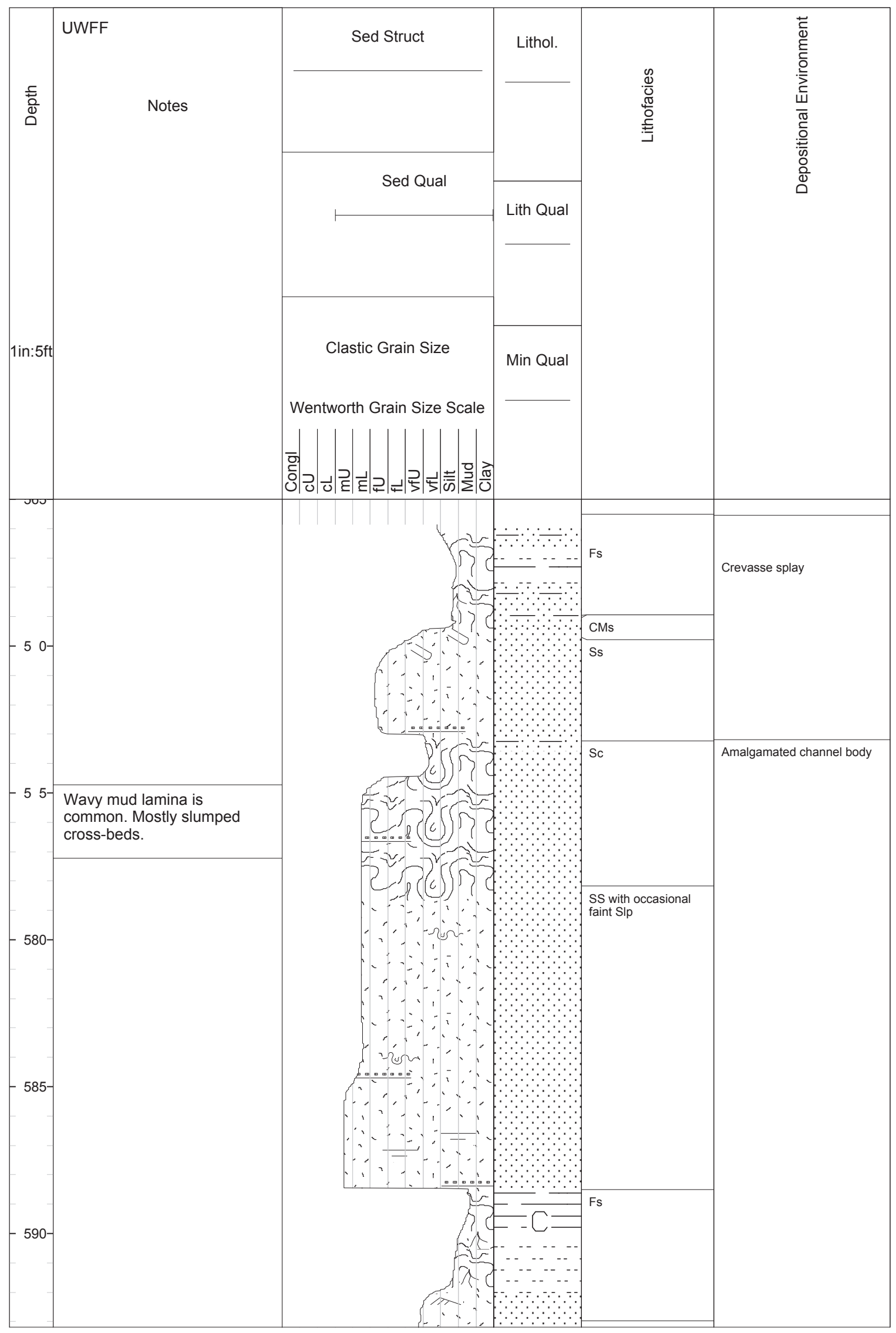




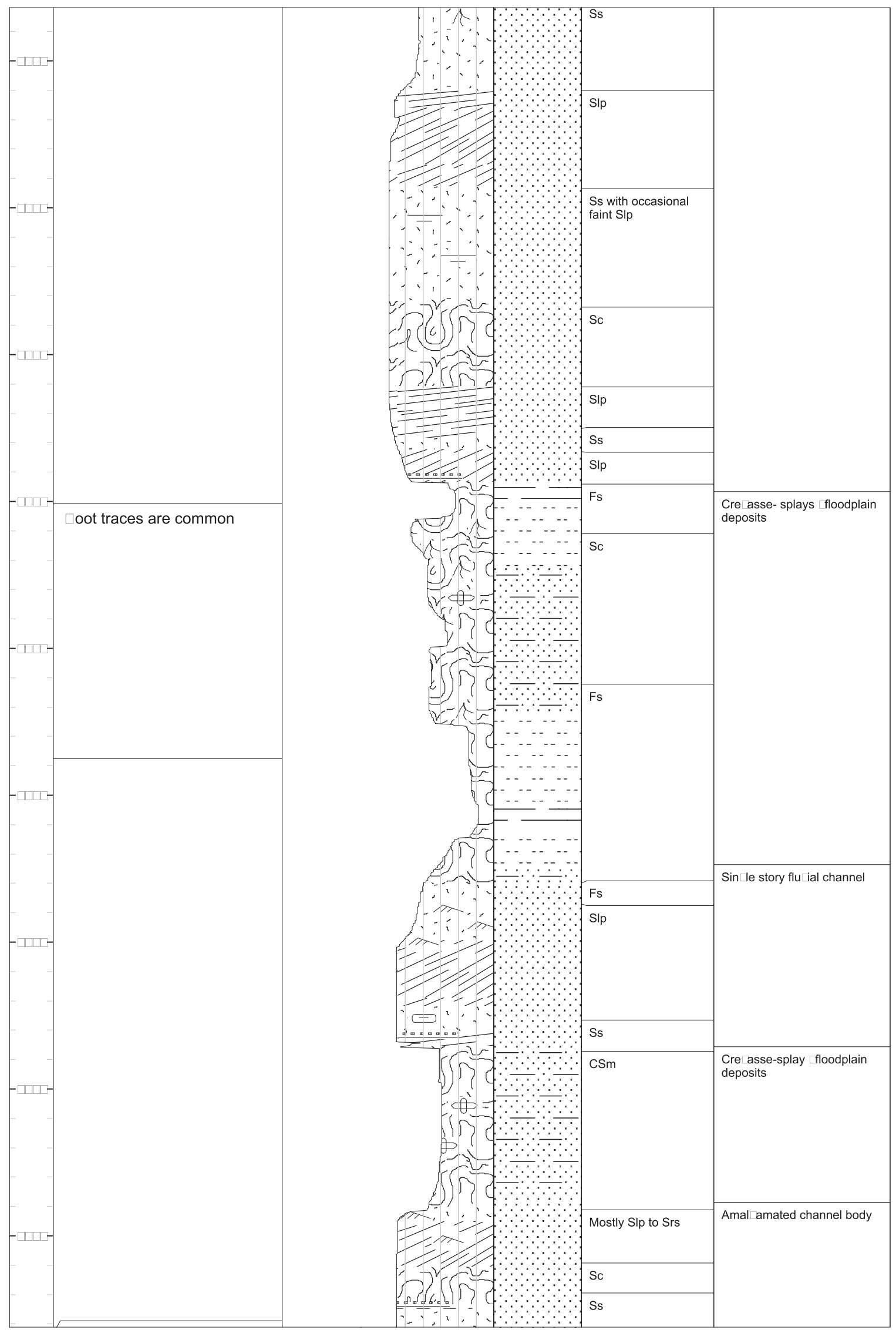




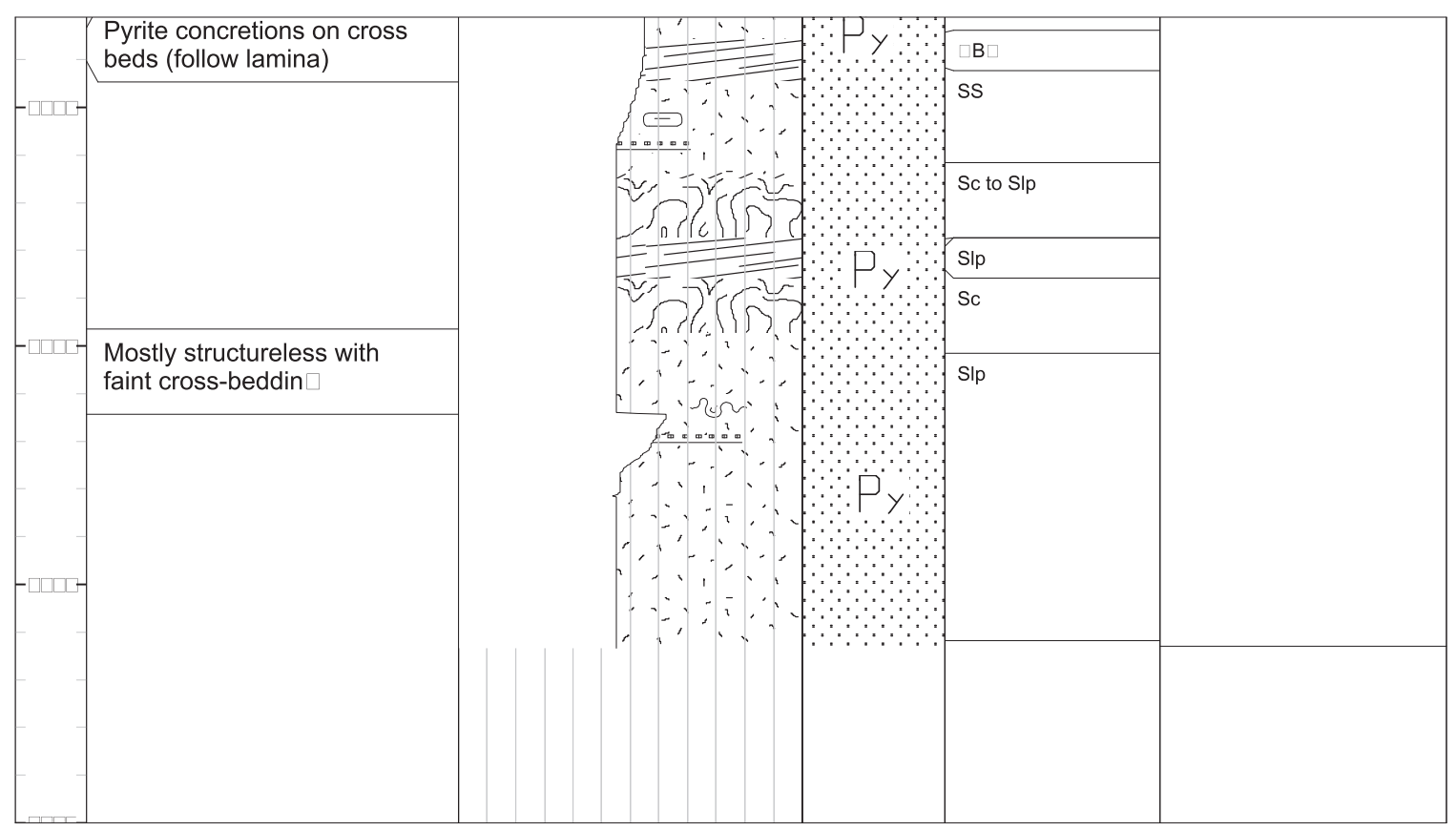


Appendix F:

Lithofacies Table

The following table is a summary of the common lithofacies of the fluvial deposits of the Mesaverde Group in the Piceance Basin, CO and Uinta Basin, UT as observed in core. 
Table of common lithofacies of the fluvial deposits of Mesaverde Group fluvial deposits as observed in core.

\begin{tabular}{|c|c|c|}
\hline $\begin{array}{l}\text { Facies Name } \\
\text { and Code }\end{array}$ & Description & Interpretation \\
\hline $\begin{array}{l}\text { Fissile Mudstone } \\
\qquad M_{F}\end{array}$ & $\begin{array}{l}\text { Texture and color: Dark-to-medium gray fissile mud with minor silt } \\
\text { Sedimentary structures: faint low angle wavy laminations, faint silty mottles } \\
\text { Bioturbation: Highly common root traces, often carbonaceous and sometimes Fe- } \\
\text { stained }\end{array}$ & $\begin{array}{l}\text { Floodplain deposit or } \\
\text { the top of an overall } \\
\text { fining upwards sequence } \\
\text { of a fluvial channel }\end{array}$ \\
\hline $\begin{array}{l}\text { Laminated to } \\
\text { Mottled } \\
\text { Mudstone } \\
\text { ML }\end{array}$ & $\begin{array}{l}\text { Texture and color: Light-to-dark gray to brown mud with minor silt } \\
\text { Sedimentary structures: Low angle wavy silty laminations, silty mottles, } \\
\text { occasionally lenticular silt } \\
\text { Bioturbation: Potentially very highly bioturbed, common root traces, mottles } \\
\text { that may correspond to insect burrowing }\end{array}$ & $\begin{array}{l}\text { Floodplain deposit or } \\
\text { the top of an overall } \\
\text { fining upwards sequence } \\
\text { of a fluvial channel }\end{array}$ \\
\hline $\begin{array}{l}\text { Carbonaceous } \\
\text { Mudstone } \\
\text { Mc }\end{array}$ & $\begin{array}{l}\text { Texture and color: Reddish-brown to dark gray mud with frequent carbonaceous } \\
\text { material, carbonaceous plant material often recognizable, sometimes Fe-stained } \\
\text { Sedimentary structures: Typically structureless sometimes mottled, faint } \\
\text { infrequent laminations which are sometimes contorted } \\
\text { Bioturbation: Very common root traces and some cryptic bioturbation }\end{array}$ & $\begin{array}{l}\text { Floodplain/overbank } \\
\text { deposit }\end{array}$ \\
\hline $\begin{array}{c}\text { Convoluted } \\
\text { Sandy Siltstone } \\
\text { STsC }\end{array}$ & $\begin{array}{l}\text { Texture and color: Light-to-medium gray or beige silt with minor vf sand, } \\
\text { occasional minor mud ocassional small carbonaceous clasts and leaf litter, } \\
\text { sometimes Fe-stained } \\
\text { Sedimentary structures: Highly convoluted probably from extensive rooting, also } \\
\text { probably fluid escape, load casts also common } \\
\text { Bioturbation: Common large to small root traces, often Fe-stained, mottled }\end{array}$ & $\begin{array}{l}\text { Crevasse splay } \\
\text { deposit }\end{array}$ \\
\hline
\end{tabular}




\begin{tabular}{|c|c|c|}
\hline $\begin{array}{l}\text { Facies Name } \\
\text { and Code }\end{array}$ & Description & Interpretation \\
\hline $\begin{array}{l}\text { Wavy Ripple } \\
\text { Laminated Silt } \\
\text { STwR }\end{array}$ & $\begin{array}{l}\text { Texture and color: Light gray silt with minor vf sand component, occasional minor } \\
\text { mud, leaf litter common } \\
\text { Sedimentary structures: wavy, closely spaced (<0.1 mm), parallel, low angle wavy } \\
\text { ripples,rare climbing ripples, ripples are often offset by micro-normal faults } \\
\text { Bioturbation: Highly common root traces, usually vertical and mud-filled }\end{array}$ & $\begin{array}{l}\text { Crevasse splay } \\
\text { deposit }\end{array}$ \\
\hline $\begin{array}{c}\text { Agrilliceous } \\
\text { Mottled Silstone } \\
\text { STAM }\end{array}$ & $\begin{array}{l}\text { Texture and color: Grayish-green silt with high clay content (possibly chlorite), } \\
\text { occasional carbonaceous matter, and white flecks (possibly carbonate soil nodules) } \\
\text { Sedimentary structures: Highly mottled to structureless, mottles are commonly } \\
\text { Fe-stained } \\
\text { Bioturbation: Highly bioturbated, cryptic "donuts" similar to paleophycus, root } \\
\text { traces common }\end{array}$ & $\begin{array}{l}\text { Floodplain/overbank } \\
\text { deposit with pedogenic } \\
\text { features }\end{array}$ \\
\hline $\begin{array}{l}\text { Convolute } \\
\text { Silty Sandstone } \\
\text { Sstc }\end{array}$ & $\begin{array}{l}\text { Texture and color: Light gray to beige very fine upper to fine lower sandstone } \\
\text { containing 0-30\% mud. Poorly to moderately sorted, angular to subangular grains. } \\
\text { Often features sharp base with angular mud rip up clasts } \\
\text { Sedimentary structures: Mud/organic matter laminae that have been broken up } \\
\text { and contorted, chaotic bands of leaf litter, density loading also common } \\
\text { Bioturbation: Very common small to large root traces which are sometimes Fe- } \\
\text { stained, some cryptic bioturbation }\end{array}$ & $\begin{array}{l}\text { Proximal area of crevasse } \\
\text { splay, possibly crevasse } \\
\text { channel or abandoned } \\
\text { channel }\end{array}$ \\
\hline $\begin{array}{c}\text { Ripple Laminated } \\
\text { Sandstone } \\
S_{R}\end{array}$ & $\begin{array}{l}\text { Texture and color: Light gray to beige very fine upper to fine upper, moderately } \\
\text { well sorted, subangular to subrounded, sandstone } \\
\text { Sedimentary structures: wavy continuous to discontinuous climbing ripples that } \\
\text { are defined by smaller grain sizes or reworked organic matter (possibly charcoal). } \\
\text { Ripple sets are } \sim 1 \mathrm{~cm} \text { thick. Occasional small mud drapes } \\
\text { Bioturbation: Some root traces, unidentified burrows - lined and unlined }\end{array}$ & $\begin{array}{l}\text { Upper coarse portion } \\
\text { of crevasse splay, } \\
\text { or upper fine portion of } \\
\text { fluvial channel }\end{array}$ \\
\hline
\end{tabular}




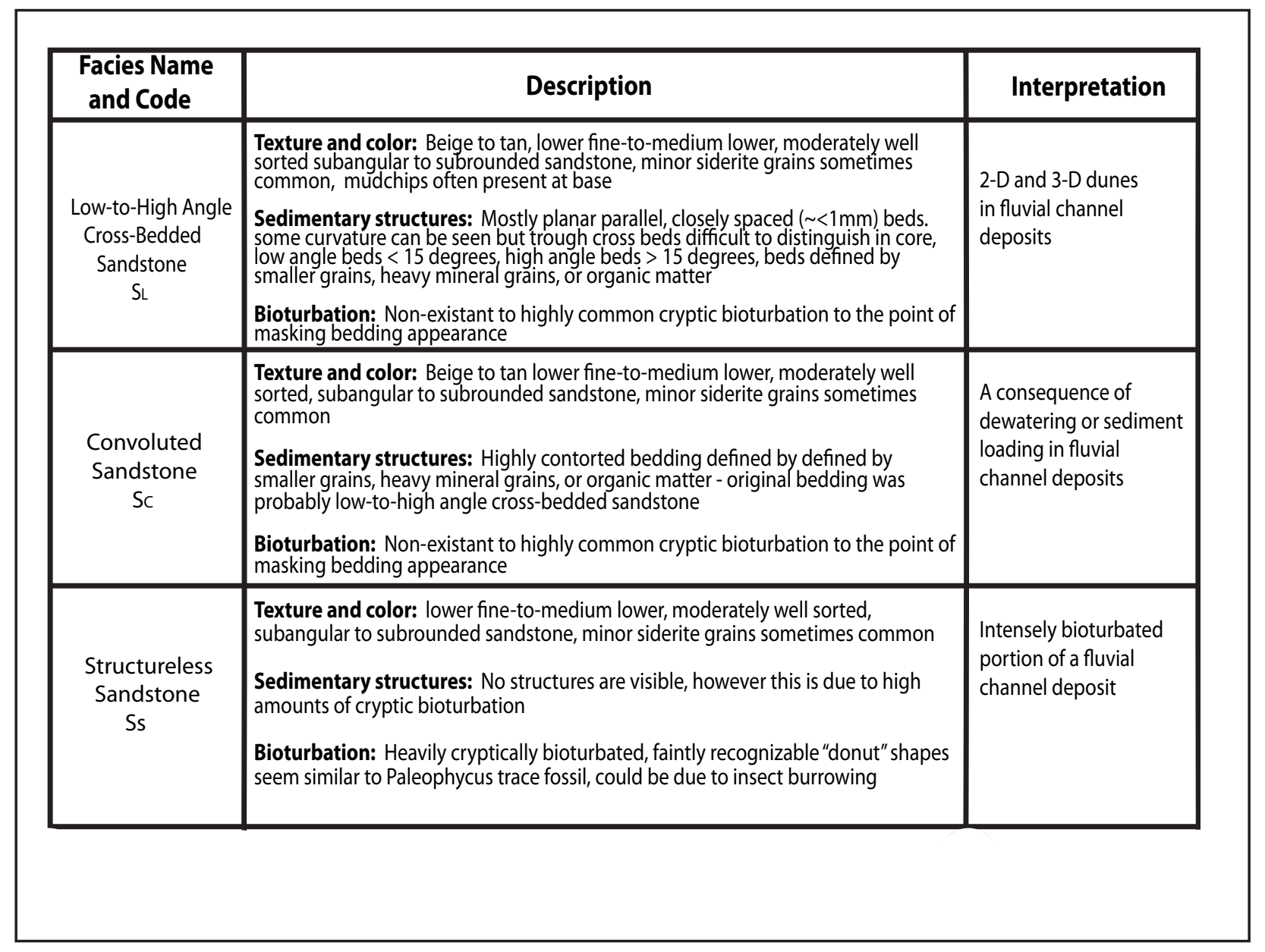


Appendix G:

Well Log Indicator Flag Approach

The following two figures $(1 \mathrm{G}$ and $2 \mathrm{G}$ ) illustrate how the program works to establish a well log indicator flag from the results of the classifiers utilized, and how this is used in a sequence of steps to create a final, merged las log curve which seeks to represent the fluvial architectural elements of the Mesaverde Group of the Piceance Basin, CO and Uinta Basin, UT. 


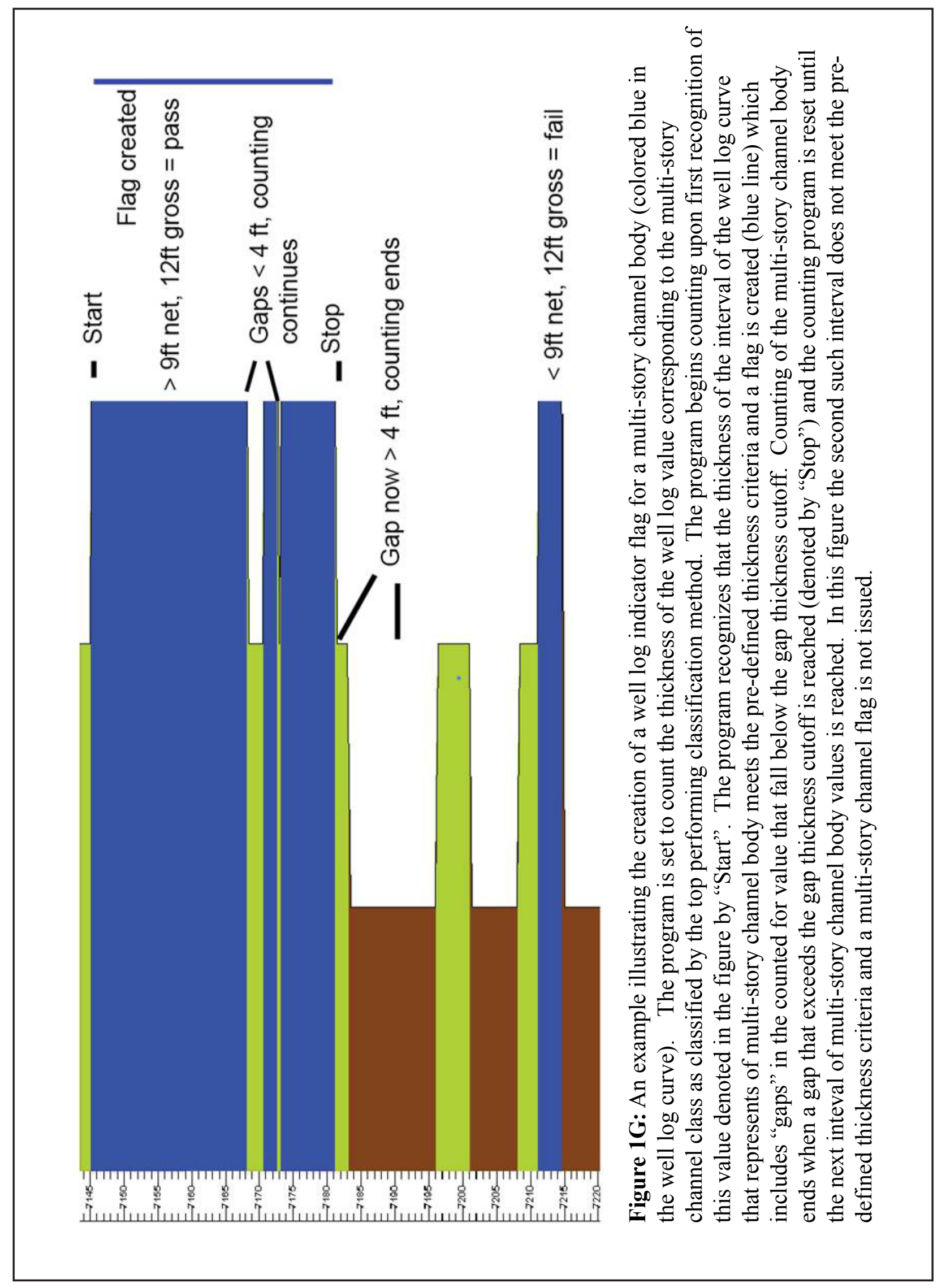


Flowchart Key

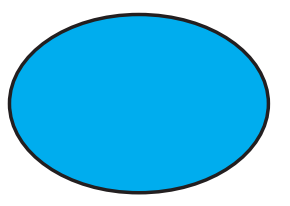

Beginning or end of a program

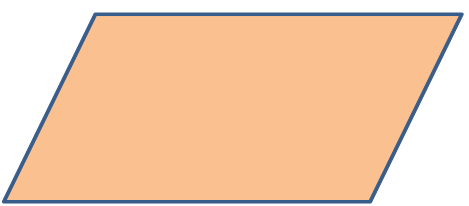

Denotes either an input operation or an output operation

Denotes a process to be carried out

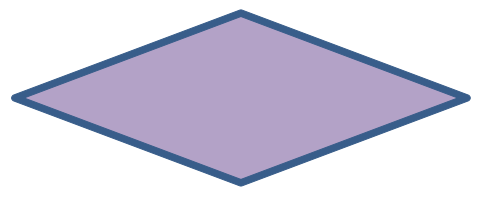

Denotes a decision to be made

Flow line 


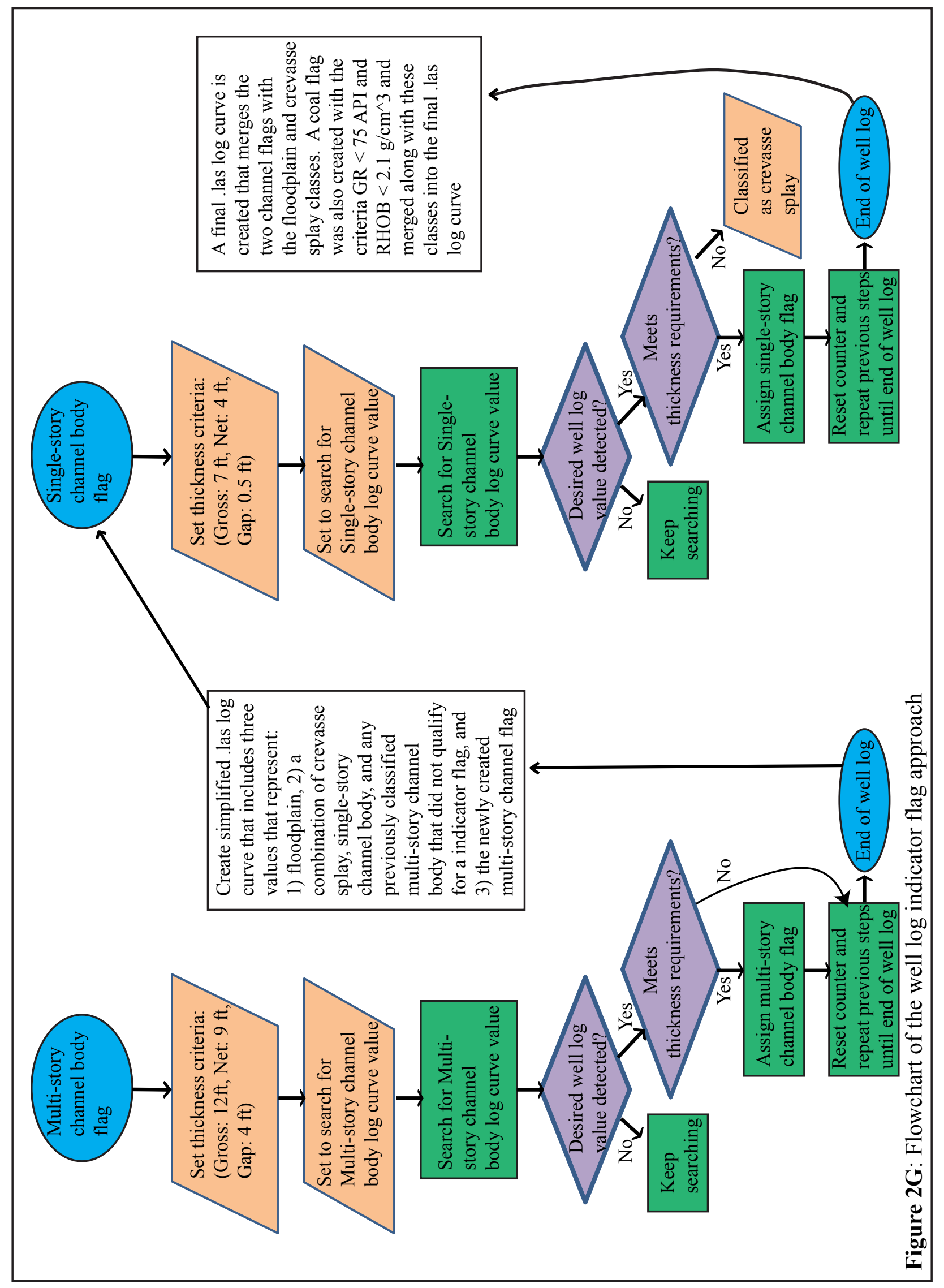




\section{Appendix H}

Accuracy Summary of the Prediction Results for Five Class Architectural-Element Realization for the k-NN Classifier

The following tables summarize the success of the variably trained k-NN classifiers' in predicting the occurrence of the individual architectural elements "user's accuracy" and the overall accuracy of the classifiers. Highlighted in yellow are two cases which produced identical best overall accuracies and their associated architectural element user's accuracies. 
Log curve assemblage: GR,RHOB

\begin{tabular}{|r|r|r|r|r|r|r|}
\hline & Overall Accuracy (\%) & \multicolumn{4}{|c|}{ Architectural Element User's Accuracy } \\
\hline & & FP & \multicolumn{1}{l|}{ CS } & SS & \multicolumn{1}{l|}{ MS } & AM \\
\hline 5 & 60.8 & 0.908 & 0.496 & 0.228 & 0.153 & 0.696 \\
\hline 10 & 62 & 0.917 & 0.489 & 0.201 & 0.134 & 0.779 \\
\hline 15 & 61.8 & 0.913 & 0.546 & 0.122 & 0.152 & 0.796 \\
\hline 20 & 62.2 & 0.926 & 0.589 & 0.069 & 0.121 & 0.825 \\
\hline 25 & 60.5 & 0.917 & 0.582 & 0.005 & 0.108 & 0.821 \\
\hline
\end{tabular}

Log curve assemblage: GR, ILD

\begin{tabular}{|r|r|r|r|r|r|r|}
\hline & Overall Accuracy (\%) & \multicolumn{4}{|c|}{ Architectural Element User's Accuracy } \\
\hline Neighbors (K) & & FP & CS & SS & MS & AM \\
\hline 5 & 52.5 & 0.891 & 0.411 & 0.074 & 0.089 & 0.533 \\
\hline 10 & 54.4 & 0.873 & 0.44 & 0.026 & 0.07 & 0.696 \\
\hline 15 & 57.1 & 0.9 & 0.482 & 0 & 0.082 & 0.767 \\
\hline 20 & 58.4 & 0.932 & 0.503 & 0 & 0.063 & 0.771 \\
\hline 25 & 59.5 & 0.934 & 0.489 & 0.011 & 0.063 & 0.821 \\
\hline
\end{tabular}

Log curve assemblage: GR, NPHI

\begin{tabular}{|r|r|r|r|r|r|r|}
\hline & Overall Accuracy (\%) & \multicolumn{4}{|c|}{ Architectural Element User's Accuracy } \\
\hline Neighbors (K) & & FP & CS & SS & MS & AM \\
\hline 5 & 57.4 & 0.858 & 0.504 & 0.042 & 0.192 & 0.742 \\
\hline 10 & 58.3 & 0.86 & 0.56 & 0.048 & 0.152 & 0.775 \\
\hline 15 & 59.8 & 0.91 & 0.574 & 0.005 & 0.139 & 0.783 \\
\hline 20 & 60 & 0.915 & 0.582 & 0.005 & 0.126 & 0.792 \\
\hline 25 & 59.7 & 0.9 & 0.574 & 0 & 0.12 & 0.82 \\
\hline
\end{tabular}

Log curve assemblage: GR, RHOB, ILD

\begin{tabular}{|r|r|r|r|r|r|r|}
\hline & Overall Accuracy (\%) & \multicolumn{5}{|c|}{ Architectural Element User's Accuracy } \\
\hline Neighbors (K) & & FP & \multicolumn{1}{l|}{ CS } & SS & MS & AM \\
\hline 5 & 60.6 & 0.908 & 0.496 & 0.228 & 0.14 & 0.696 \\
\hline 10 & 62 & 0.917 & 0.489 & 0.201 & 0.134 & 0.779 \\
\hline 15 & 61.9 & 0.913 & 0.546 & 0.121 & 0.158 & 0.796 \\
\hline 20 & 62.3 & 92.6 & 0.589 & 0.069 & 0.121 & 0.829 \\
\hline 25 & 60.5 & 0.917 & 0.582 & 0.005 & 0.108 & 0.821 \\
\hline
\end{tabular}


Log curve assemblage: GR,RHOB, NPHI

\begin{tabular}{|r|r|r|r|r|r|r|}
\hline & Overall Accuracy (\%) & \multicolumn{4}{|c|}{ Architectural Element User's Accuracy } \\
\hline Neighbors (K) & & FP & \multicolumn{1}{l|}{ CS } & SS & \multicolumn{1}{l|}{ MS } & \multicolumn{1}{|c|}{ AM } \\
\hline 5 & 62.4 & 0.89 & 0.475 & 0.111 & 0.287 & 0.825 \\
\hline 10 & 62.7 & 0.884 & 0.532 & 0.063 & 0.291 & 0.858 \\
\hline 15 & 63.6 & 0.893 & 0.574 & 0.026 & 0.266 & 0.904 \\
\hline 20 & 63.8 & 0.897 & 0.624 & 0.026 & 0.228 & 0.904 \\
\hline 25 & 63 & 0.9 & 0.589 & 0.011 & 0.222 & 0.896 \\
\hline
\end{tabular}

Log curve assemblage: GR, NPHI, ILD

\begin{tabular}{|r|r|r|r|r|r|r|}
\hline & Overall Accuracy (\%) & \multicolumn{5}{|c|}{ Architectural Element User's Accuracy } \\
\hline Neighbors (K) & & FP & \multicolumn{1}{l|}{ CS } & SS & \multicolumn{1}{l|}{ MS } & \multicolumn{1}{|c|}{ AM } \\
\hline 5 & 57.4 & 0.856 & 0.504 & 0.042 & 0.199 & 0.742 \\
\hline 10 & 58.3 & 0.86 & 0.56 & 0.048 & 0.146 & 0.775 \\
\hline 15 & 59.8 & 0.91 & 0.574 & 0.005 & 0.139 & 0.783 \\
\hline 20 & 60 & 0.915 & 0.582 & 0.005 & 0.127 & 0.792 \\
\hline 25 & 59.8 & 0.9 & 0.574 & 0 & 0.12 & 0.821 \\
\hline
\end{tabular}

Log curve assemblage: GR, RHOB, ILD, NPHI

\begin{tabular}{|r|r|r|r|r|r|r|}
\hline & Overall Accuracy (\%) & \multicolumn{4}{|c|}{ Architectural Element User's Accuracy } \\
\hline Neighbors (K) & & FP & \multicolumn{1}{l|}{ CS } & \multicolumn{1}{l|}{ SS } & \multicolumn{1}{l|}{ MS } & \multicolumn{1}{|l|}{ AM } \\
\hline 5 & 62.4 & 0.891 & 0.475 & 0.111 & 0.287 & 0.825 \\
\hline 10 & 62.7 & 0.884 & 0.532 & 0.063 & 0.291 & 0.858 \\
\hline 15 & 63.6 & 0.893 & 0.574 & 0.026 & 0.266 & 0.904 \\
\hline 20 & 63.8 & 0.897 & 0.624 & 0.026 & 0.228 & 0.904 \\
\hline 25 & 63 & 0.9 & 0.589 & 0.011 & 0.222 & 0.896 \\
\hline
\end{tabular}




\section{Appendix I}

Confusion Matrices for the Five Class Architectural-Element Realization of the Variably Trained k-NN Classifiers

The following tables are the confusion matrices for each variably trained (varying welllog-curve assemblages and k values) k-NN classifier that was tested. These provide a visualization of how the testing samples were both correctly and incorrectly predicted. A common theme throughout the matrices is the misclassification of the single-story channel body architectural element class with the crevasse splay class and the high degree of confusion between the multi-story channel body and amalgamated channel body classes. This confusion is reflected in the poor predicted volumes (values distant from the ideal value of 100) calculated for these classes which contribute to high average deviation values posted at the top right hand corner of each matrix. 
Log curve assemblage: GR,RHOB

\begin{tabular}{|r|r|r|r|r|r|r|}
\hline & Overall Accuracy (\%) & \multicolumn{5}{|c|}{ Architectural Element User's Accuracy } \\
\hline Neighbors (K) & & FP & CS & SS & MS & AM \\
\hline 5 & 60.8 & 0.908 & 0.496 & 0.228 & 0.153 & 0.696 \\
\hline 10 & 62 & 0.917 & 0.489 & 0.201 & 0.134 & 0.779 \\
\hline 15 & 61.8 & 0.913 & 0.546 & 0.122 & 0.152 & 0.796 \\
\hline 20 & 62.2 & 0.926 & 0.589 & 0.069 & 0.121 & 0.825 \\
\hline 25 & 60.5 & 0.917 & 0.582 & 0.005 & 0.108 & 0.821 \\
\hline
\end{tabular}

Log curve assemblage: GR, ILD

\begin{tabular}{|r|r|r|r|r|r|r|}
\hline & Overall Accuracy (\%) & \multicolumn{5}{|c|}{ Architectural Element User's Accuracy } \\
\hline Neighbors (K) & & FP & CS & SS & MS & AM \\
\hline 5 & 52.5 & 0.891 & 0.411 & 0.074 & 0.089 & 0.533 \\
\hline 10 & 54.4 & 0.873 & 0.44 & 0.026 & 0.07 & 0.696 \\
\hline 15 & 57.1 & 0.9 & 0.482 & 0 & 0.082 & 0.767 \\
\hline 20 & 58.4 & 0.932 & 0.503 & 0 & 0.063 & 0.771 \\
\hline 25 & 59.5 & 0.934 & 0.489 & 0.011 & 0.063 & 0.821 \\
\hline
\end{tabular}

Log curve assemblage: GR, NPHI

\begin{tabular}{|r|r|r|r|r|r|r|}
\hline & Overall Accuracy (\%) & \multicolumn{5}{|c|}{ Architectural Element User's Accuracy } \\
\hline Neighbors (K) & & FP & CS & SS & MS & AM \\
\hline 5 & 57.4 & 0.858 & 0.504 & 0.042 & 0.192 & 0.742 \\
\hline 10 & 58.3 & 0.86 & 0.56 & 0.048 & 0.152 & 0.775 \\
\hline 15 & 59.8 & 0.91 & 0.574 & 0.005 & 0.139 & 0.783 \\
\hline 20 & 60 & 0.915 & 0.582 & 0.005 & 0.126 & 0.792 \\
\hline 25 & 59.7 & 0.9 & 0.574 & 0 & 0.12 & 0.82 \\
\hline
\end{tabular}

Log curve assemblage: GR, RHOB, ILD

\begin{tabular}{|r|r|r|r|r|r|r|}
\hline & Overall Accuracy (\%) & \multicolumn{5}{|c|}{ Architectural Element User's Accuracy } \\
\hline Neighbors (K) & & FP & CS & SS & MS & AM \\
\hline 5 & 60.6 & 0.908 & 0.496 & 0.228 & 0.14 & 0.696 \\
\hline 10 & 62 & 0.917 & 0.489 & 0.201 & 0.134 & 0.779 \\
\hline 15 & 61.9 & 0.913 & 0.546 & 0.121 & 0.158 & 0.796 \\
\hline 20 & 62.3 & 92.6 & 0.589 & 0.069 & 0.121 & 0.829 \\
\hline 25 & 60.5 & 0.917 & 0.582 & 0.005 & 0.108 & 0.821 \\
\hline
\end{tabular}


Log curve assemblage: GR,RHOB, NPHI

\begin{tabular}{|r|r|r|r|r|r|r|}
\hline & Overall Accuracy (\%) & \multicolumn{5}{|c|}{ Architectural Element User's Accuracy } \\
\hline Neighbors (K) & & FP & \multicolumn{1}{c|}{ S } & SS & MS & AM \\
\hline 5 & 62.4 & 0.89 & 0.475 & 0.111 & 0.287 & 0.825 \\
\hline 10 & 62.7 & 0.884 & 0.532 & 0.063 & 0.291 & 0.858 \\
\hline 15 & 63.6 & 0.893 & 0.574 & 0.026 & 0.266 & 0.904 \\
\hline 20 & 63.8 & 0.897 & 0.624 & 0.026 & 0.228 & 0.904 \\
\hline 25 & 63 & 0.9 & 0.589 & 0.011 & 0.222 & 0.896 \\
\hline
\end{tabular}

Log curve assemblage: GR, NPHI, ILD

\begin{tabular}{|r|r|r|r|r|r|r|}
\hline & Overall Accuracy (\%) & \multicolumn{5}{|c|}{ Architectural Element User's Accuracy } \\
\hline Neighbors (K) & & FP & CS & SS & MS & AM \\
\hline 5 & 57.4 & 0.856 & 0.504 & 0.042 & 0.199 & 0.742 \\
\hline 10 & 58.3 & 0.86 & 0.56 & 0.048 & 0.146 & 0.775 \\
\hline 15 & 59.8 & 0.91 & 0.574 & 0.005 & 0.139 & 0.783 \\
\hline 20 & 60 & 0.915 & 0.582 & 0.005 & 0.127 & 0.792 \\
\hline 25 & 59.8 & 0.9 & 0.574 & 0 & 0.12 & 0.821 \\
\hline
\end{tabular}

Log curve assemblage: GR, RHOB, ILD, NPHI

\begin{tabular}{|r|r|r|r|r|r|r|}
\hline & Overall Accuracy (\%) & \multicolumn{5}{|c|}{ Architectural Element User's Accuracy } \\
\hline Neighbors (K) & & FP & CS & SS & MS & AM \\
\hline 5 & 62.4 & 0.891 & 0.475 & 0.111 & 0.287 & 0.825 \\
\hline 10 & 62.7 & 0.884 & 0.532 & 0.063 & 0.291 & 0.858 \\
\hline 15 & 63.6 & 0.893 & 0.574 & 0.026 & 0.266 & 0.904 \\
\hline 20 & 63.8 & 0.897 & 0.624 & 0.026 & 0.228 & 0.904 \\
\hline 25 & 63 & 0.9 & 0.589 & 0.011 & 0.222 & 0.896 \\
\hline
\end{tabular}




\section{Appendix J}

Accuracy Summary of the Prediction Results for Four Class Architectural-Element Realization for the k-NN Classifier

The following tables summarize the success of the variably trained k-NN classifiers' in predicting the occurrence of the individual architectural elements "user's accuracy" and the overall accuracy of the classifiers. Highlighted in yellow are two cases which produced identical best overall accuracies and their associated architectural element user's accuracies. It is important to note the increase in both overall and user's accuracies with successively larger k values up to $\mathrm{k}=20$, where after in a majority of well-log-curve assemblages (GR, RHOB; GR, RHOB, ILD; GR, RHOB, NPHI; and GR, RHOB, ILD, NPHI). It should also be noted that no one well-log-curve assemblage predicted an individual architectural element class markedly better than the others. 


\begin{tabular}{|r|r|r|r|r|r|}
\hline \multicolumn{6}{|l|}{ Log curve assemblage: GR,RHOB } \\
\hline & Overall Accuracy (\%) & \multicolumn{4}{|c|}{ Architectural Element User's Accuracy } \\
\hline Neighbors (K) & & FP & CS & SS & MS \\
\hline 5 & 73.9 & 0.908 & 0.475 & 0.212 & 0.889 \\
\hline 10 & 74 & 0.917 & 0.461 & 0.201 & 0.892 \\
\hline 15 & 74 & 0.913 & 0.496 & 0.122 & 0.922 \\
\hline 20 & 74.5 & 0.926 & 0.539 & 0.069 & 0.932 \\
\hline 25 & 73.2 & 0.917 & 0.525 & 0.005 & 0.94 \\
\hline
\end{tabular}

Log curve assemblage: GR, ILD

\begin{tabular}{|r|r|r|r|r|r|}
\hline & Overall Accuracy (\%) & \multicolumn{5}{|c|}{ Architectural Element User's Accuracy } \\
\hline Neighbors (K) & & FP & CS & SS & MS \\
\hline 5 & 65 & 0.891 & 0.404 & 0.063 & 0.736 \\
\hline 10 & 66.4 & 0.873 & 0.433 & 0.021 & 0.812 \\
\hline 15 & 69.7 & 0.9 & 0.489 & 0 & 0.869 \\
\hline 20 & 70.9 & 0.93 & 0.489 & 0 & 0.867 \\
\hline 25 & 71.6 & 0.934 & 0.475 & 0.011 & 0.884 \\
\hline
\end{tabular}

Log curve assemblage: GR, NPHI

\begin{tabular}{|r|r|r|r|r|r|}
\hline & Overall Accuracy (\%) & \multicolumn{5}{|c|}{ Architectural Element User's Accuracy } \\
\hline Neighbors (K) & & FP & CS & SS & MS \\
\hline 5 & 65.4 & 0.858 & 0.511 & 0.032 & 0.765 \\
\hline 10 & 67.9 & 0.86 & 0.532 & 0.042 & 0.824 \\
\hline 15 & 70.2 & 0.91 & 0.567 & 0.005 & 0.839 \\
\hline 20 & 70.3 & 0.915 & 0.56 & 0 & 0.844 \\
\hline 25 & 70.7 & 0.9 & 0.567 & 0 & 0.869 \\
\hline
\end{tabular}

Log curve assemblage: GR, RHOB, ILD

\begin{tabular}{|r|r|r|r|r|r|}
\hline & Overall Accuracy (\%) & \multicolumn{5}{|c|}{ Architectural Element User's Accuracy } \\
\hline Neighbors (K) & & FP & \multicolumn{1}{l|}{ CS } & \multicolumn{1}{l|}{ SS } & \multicolumn{1}{l|}{ MS } \\
\hline 5 & 73.8 & 0.908 & 0.475 & 0.211 & 0.884 \\
\hline 10 & 74 & 0.917 & 0.461 & 0.201 & 0.892 \\
\hline 15 & 74 & 0.912 & 0.496 & 0.122 & 0.922 \\
\hline 20 & 74.5 & 0.926 & 0.539 & 0.069 & 0.932 \\
\hline 25 & 73.3 & 0.917 & 0.525 & 0.005 & 0.94 \\
\hline
\end{tabular}




\begin{tabular}{|c|c|c|c|c|c|}
\hline \multicolumn{6}{|c|}{ Log curve assemblage: GR,RHOB, NPHI } \\
\hline & Overall Accuracy (\%) & \multicolumn{4}{|c|}{ Architectural Element User's Accuracy } \\
\hline Neighbors (K) & & FP & CS & SS & MS \\
\hline 5 & 72.1 & 0.891 & 0.468 & 0.106 & 0.907 \\
\hline 10 & 72.1 & 0.884 & 0.525 & 0.053 & 0.922 \\
\hline 15 & 72.7 & 0.893 & 0.546 & 0.026 & 0.932 \\
\hline 20 & 73.6 & 0.897 & 0.574 & 0.026 & 0.945 \\
\hline 25 & 73.4 & 0.9 & 0.56 & 0.011 & 0.95 \\
\hline \multicolumn{6}{|c|}{ Log curve assemblage: GR, NPHI, ILD } \\
\hline & Overall Accuracy (\%) & \multicolumn{4}{|c|}{ Architectural Element User's Accuracy } \\
\hline Neighbors (K) & & FP & CS & SS & MS \\
\hline 5 & 65.4 & 0.856 & 0.51 & 0.032 & 0.768 \\
\hline 10 & 67.9 & 0.86 & 0.532 & 0.042 & 0.824 \\
\hline 15 & 70.2 & 0.91 & 0.567 & 0.005 & 0.839 \\
\hline 20 & 70.3 & 0.915 & 0.56 & 0 & 0.844 \\
\hline 25 & 70.7 & 0.9 & 0.567 & 0 & 0.869 \\
\hline \multicolumn{6}{|c|}{ Log curve assemblage: GR, RHOB, ILD, NPHI } \\
\hline & Overall Accuracy (\%) & \multicolumn{4}{|c|}{ Architectural Element User's Accuracy } \\
\hline Neighbors (K) & & FP & CS & SS & MS \\
\hline 5 & 72.1 & 0.891 & 0.468 & 0.106 & 0.907 \\
\hline 10 & 72.2 & 0.884 & 0.525 & 0.053 & 0.922 \\
\hline 15 & 72.7 & 0.893 & 0.546 & 0.026 & 0.932 \\
\hline 20 & 73.6 & 0.897 & 0.574 & 0.026 & 0.944 \\
\hline 25 & 73.4 & 0.9 & 0.56 & 0.011 & 0.95 \\
\hline
\end{tabular}




\section{Appendix K}

Confusion Matrices for the Four Class Architectural-Element Realization of the Variably Trained k-NN Classifiers

The following tables are the confusion matrices for each variably trained (varying welllog-curve assemblages and k values) k-NN classifier that was tested for the simplified four class architectural element realization. These provide a visualization of how the testing samples were both correctly and incorrectly predicted. It can be observed that with the combination of the geologically similar multi-story channel body and amalgamated channel body classes of the previous five class architectural element realization into a single multi-story channel body class, the degree of inter-class confusion is lessened as denoted by average deviation values which are lower than those found in Appendix I. 


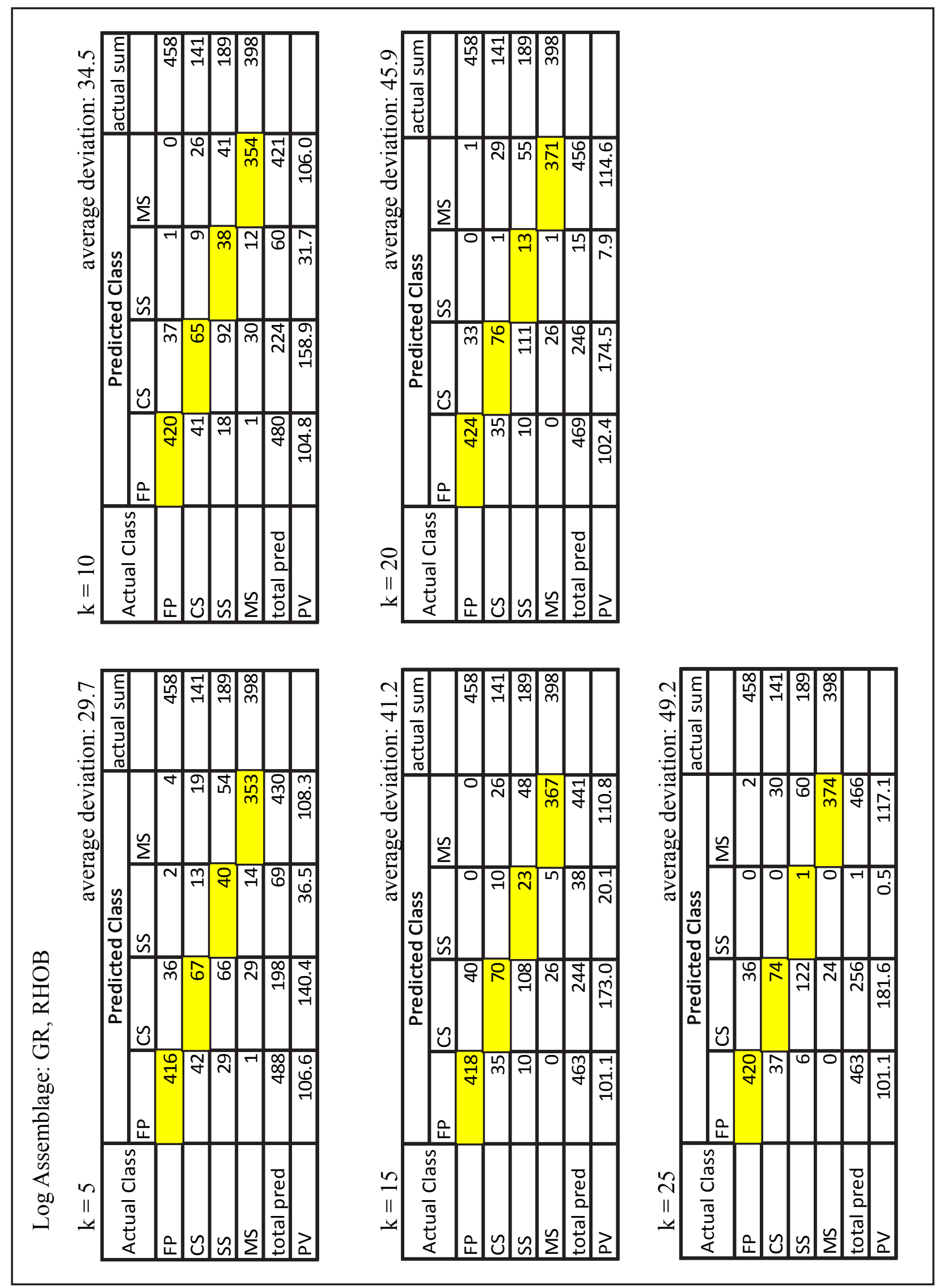



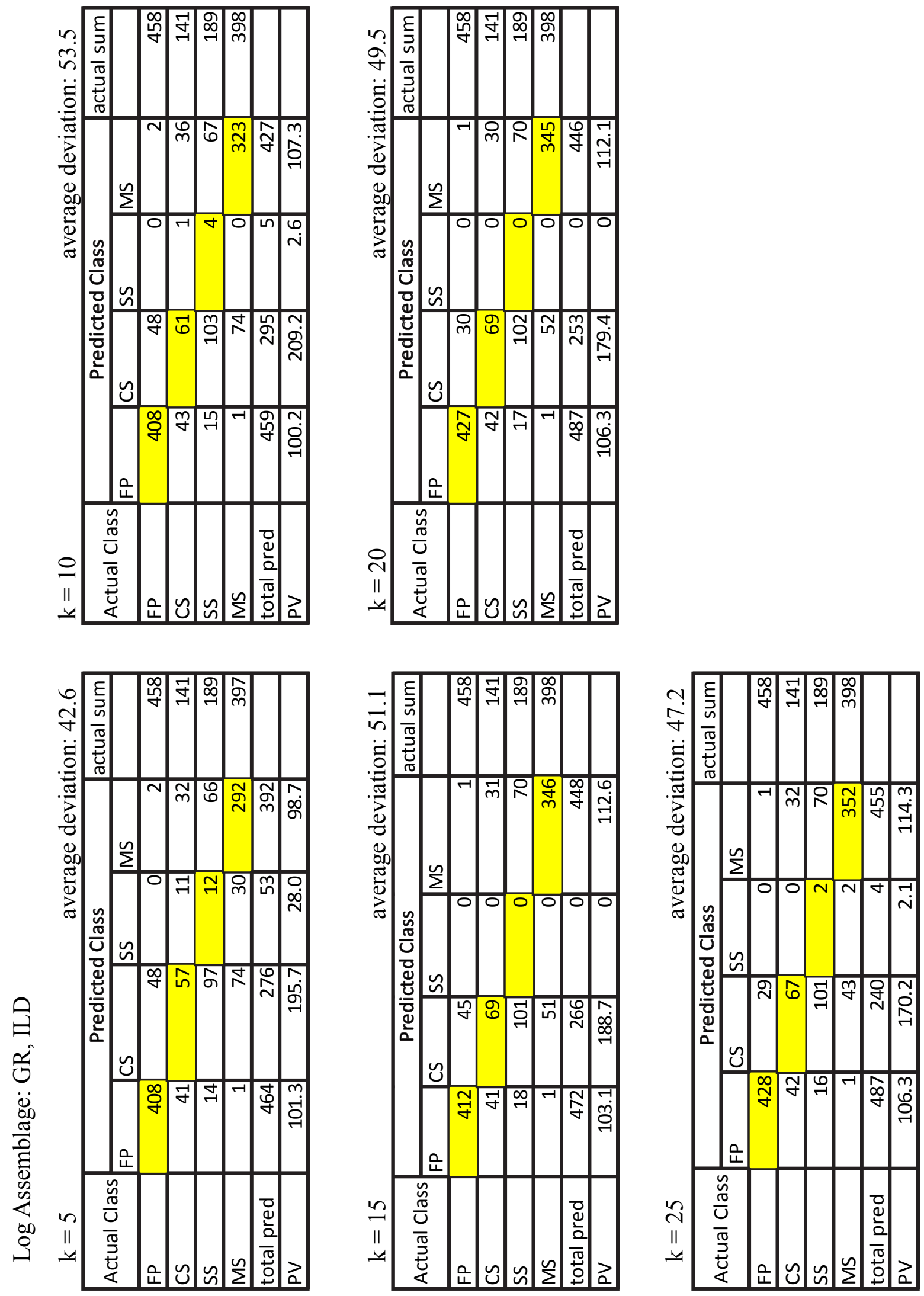

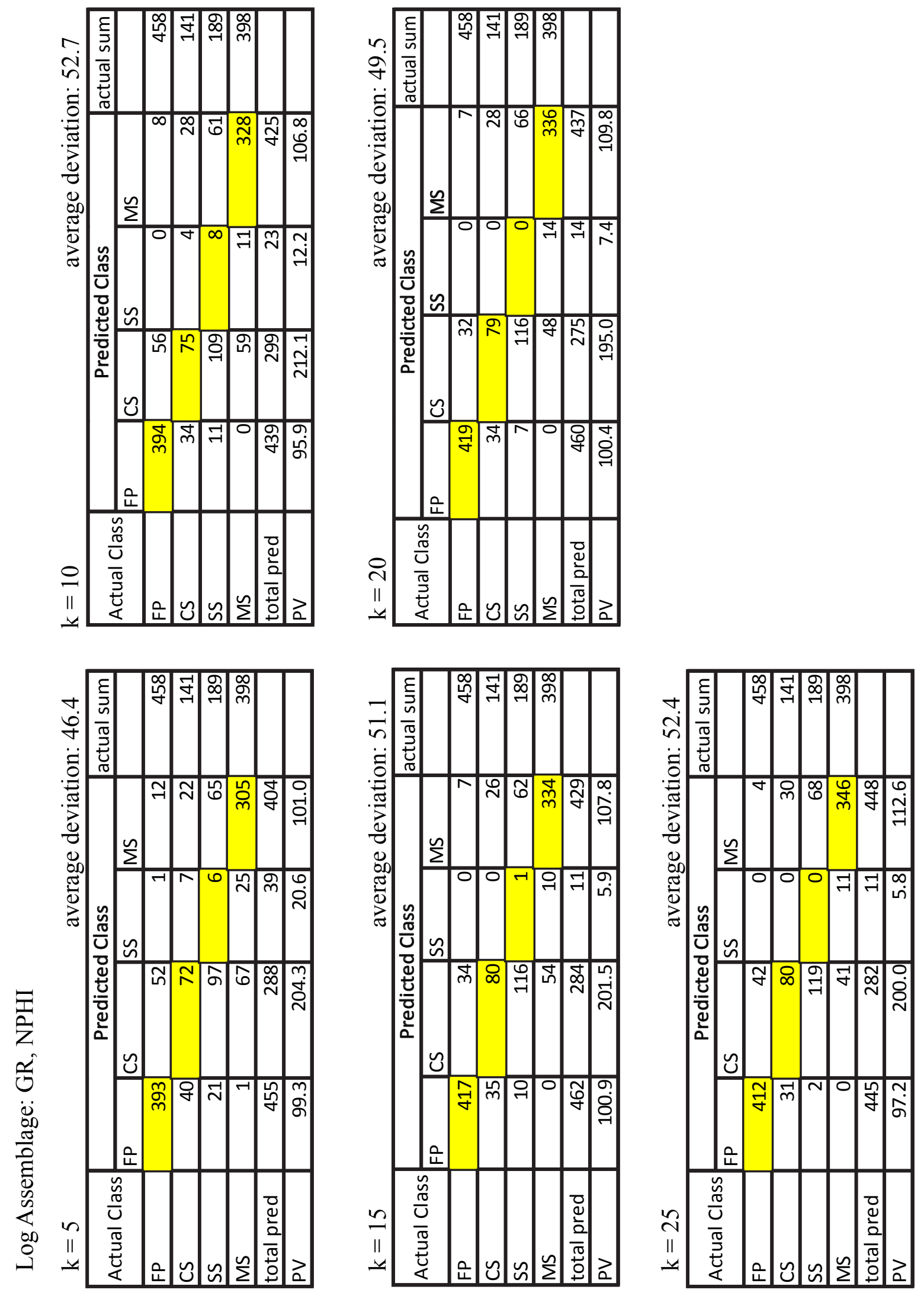


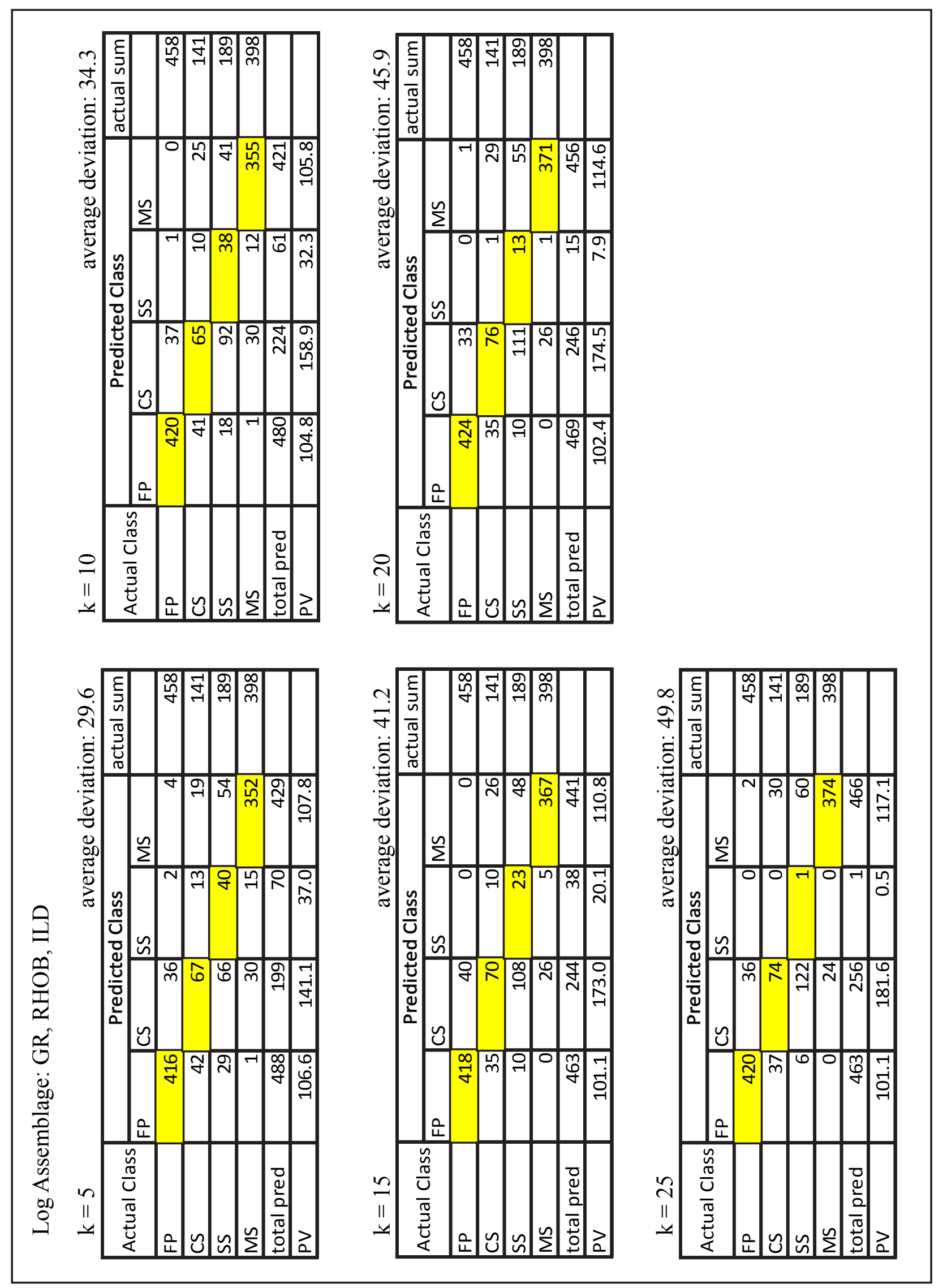




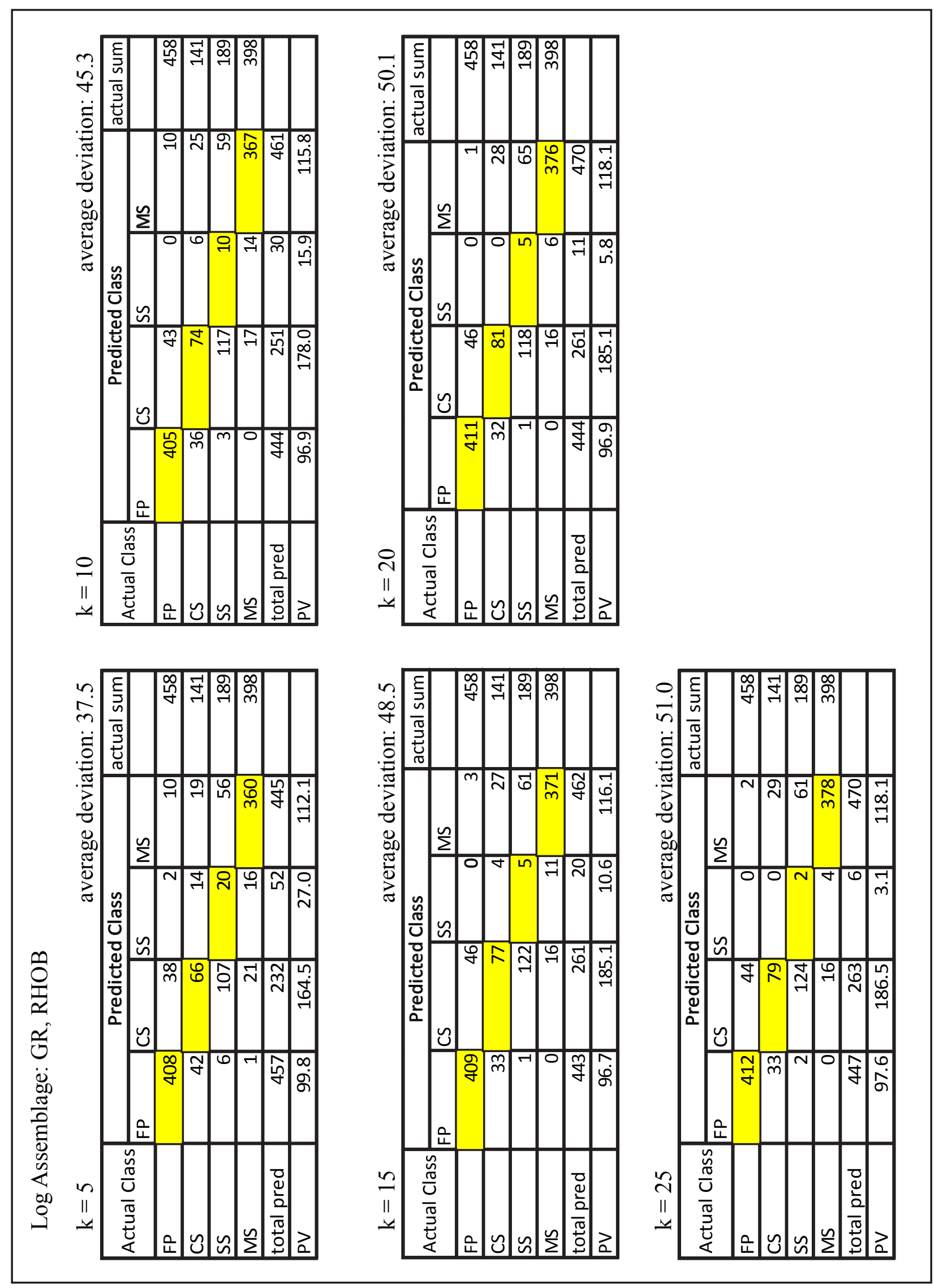




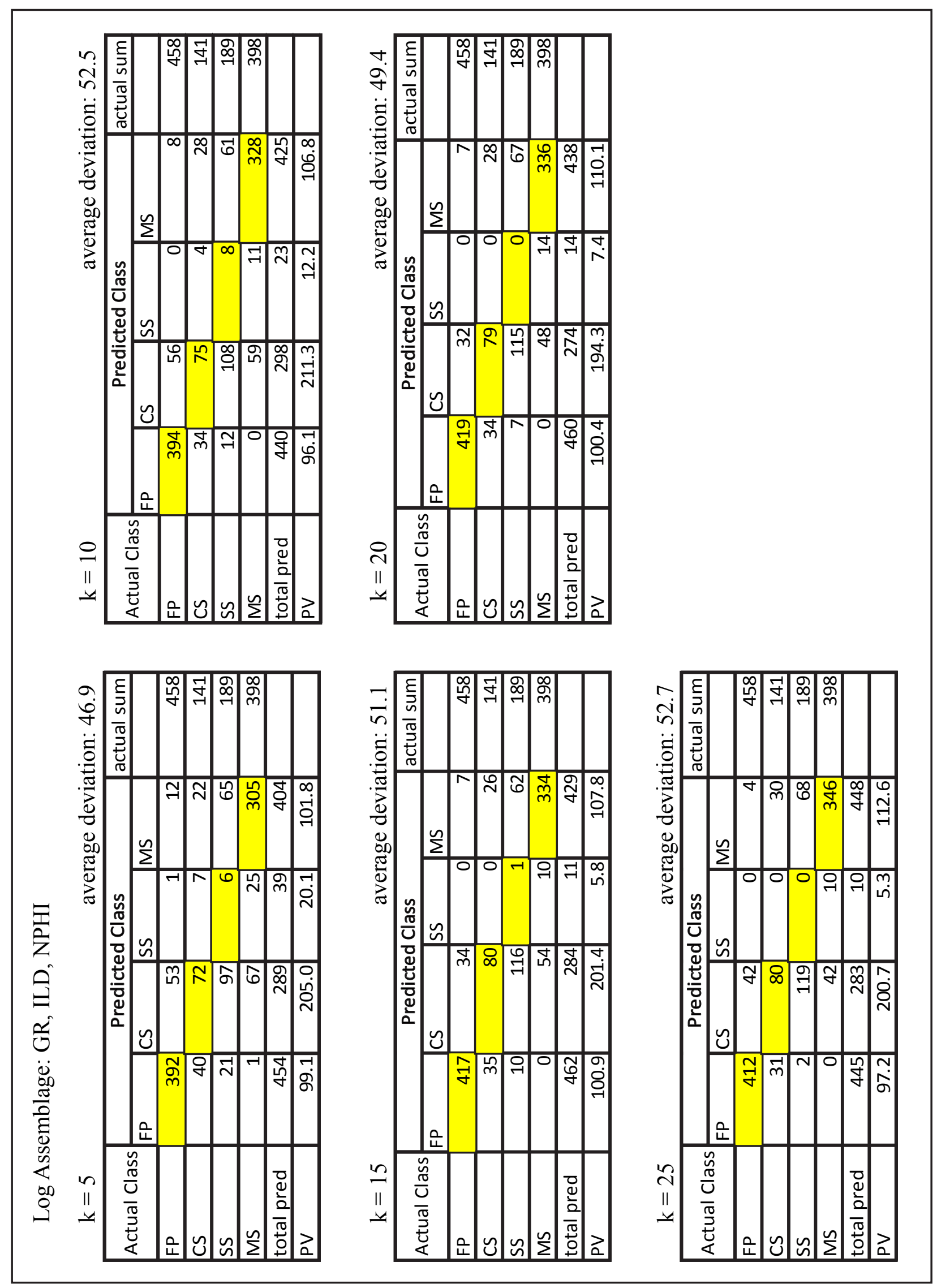




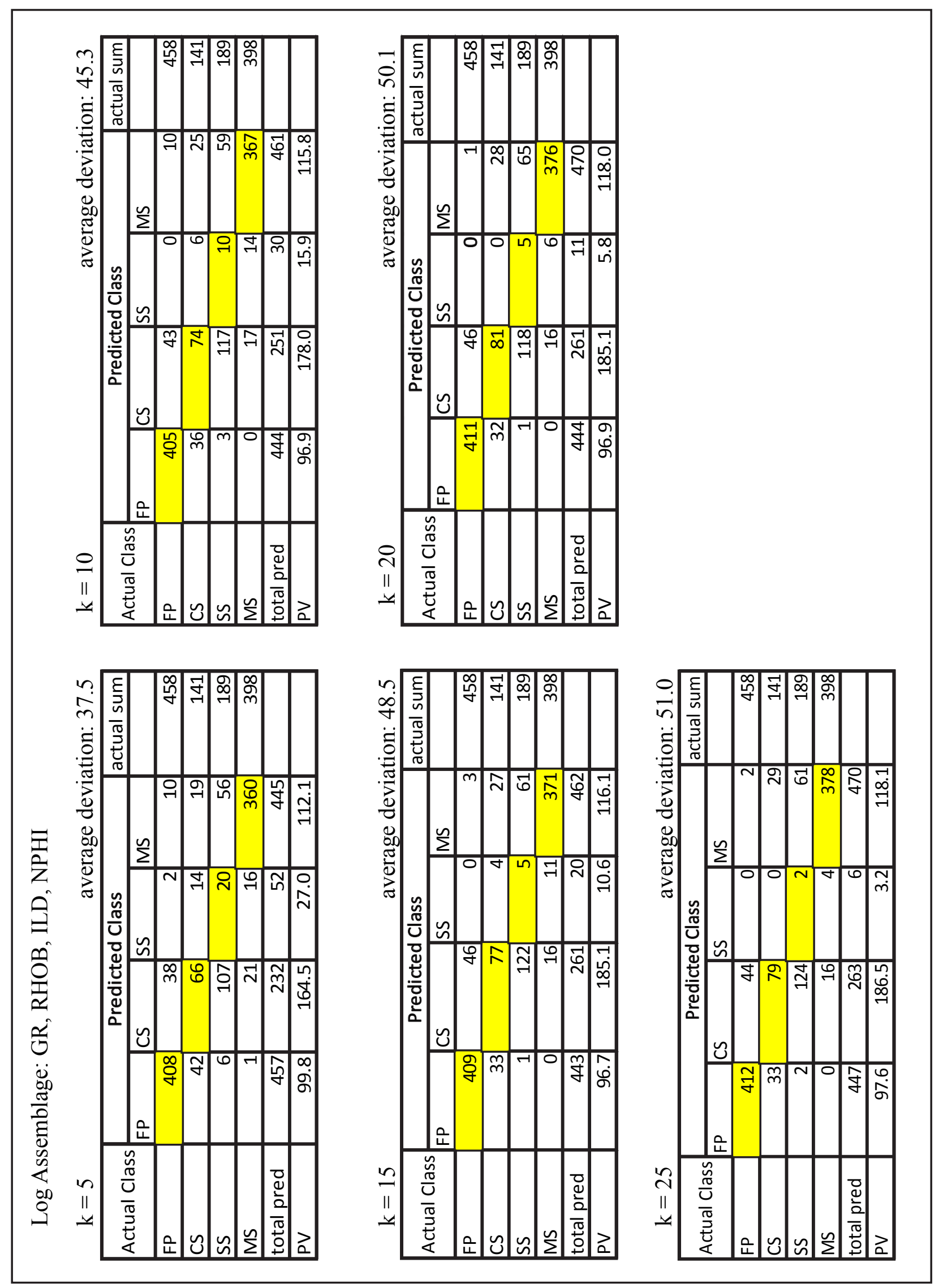




\section{Appendix L}

Accuracy Summary of the Prediction Results for Five Class Architectural-Element Realization for the PCP Classifier

The following tables summarize the success of the variably trained PCP classifiers' in predicting the occurrence of the individual architectural elements "user's accuracy" and the overall accuracy of the classifiers. Highlighted in yellow are two cases which produced identical best overall accuracies and their associated architectural element user's accuracies. 


\begin{tabular}{|l|r|r|r|r|r|r|}
\hline \multirow{2}{*}{ Well-Log-Curve Assemblage } & \multirow{2}{*}{ Overall Accuracy (\%) } & \multicolumn{5}{|c|}{ Architectural Element User's Accuracy } \\
\cline { 3 - 7 } & & FP & CS & SS & MS & AM \\
\hline GR, RHOB & 58.9 & 0.902 & 0.525 & 0 & 0.297 & 0.683 \\
\hline GR, ILD & 57.8 & 0.873 & 0.333 & 0 & 0 & 0.987 \\
\hline GR, NPHI & 60.5 & 0.904 & 0.291 & 0 & 0.253 & 0.929 \\
\hline GR, RHOB, ILD & 59.9 & 0.889 & 0.582 & 0 & 0.158 & 0.871 \\
\hline GR, RHOB, NPHI & 62 & 0.873 & 0.504 & 0 & 0.297 & 0.904 \\
\hline GR, ILD, NPH & 60.1 & 0.86 & 0.34 & 0 & 0.354 & 0.896 \\
\hline GR, RHOB, ILD, NPHI & 62 & 0.869 & 0.489 & 0 & 0.335 & 0.896 \\
\hline
\end{tabular}




\section{Appendix M}

Confusion Matrices for the Five Class Architectural-Element Realization of the Variably Trained PCP Classifiers

The following tables are the confusion matrices for each variably trained (varying welllog-curve assemblages) PCP classifier that was tested. These provide a visualization of how the testing samples were both correctly and incorrectly predicted. A common theme throughout the matrices is the misclassification of the single-story channel body architectural element class with the crevasse splay and amalgamated channel body classes and the high degree of confusion between the multi-story channel body and amalgamated channel body classes. This confusion is reflected in the poor predicted volumes (values distant from the ideal value of 100) calculated for these classes which contribute to high average deviation values posted at the top right hand corner of each matrix. 

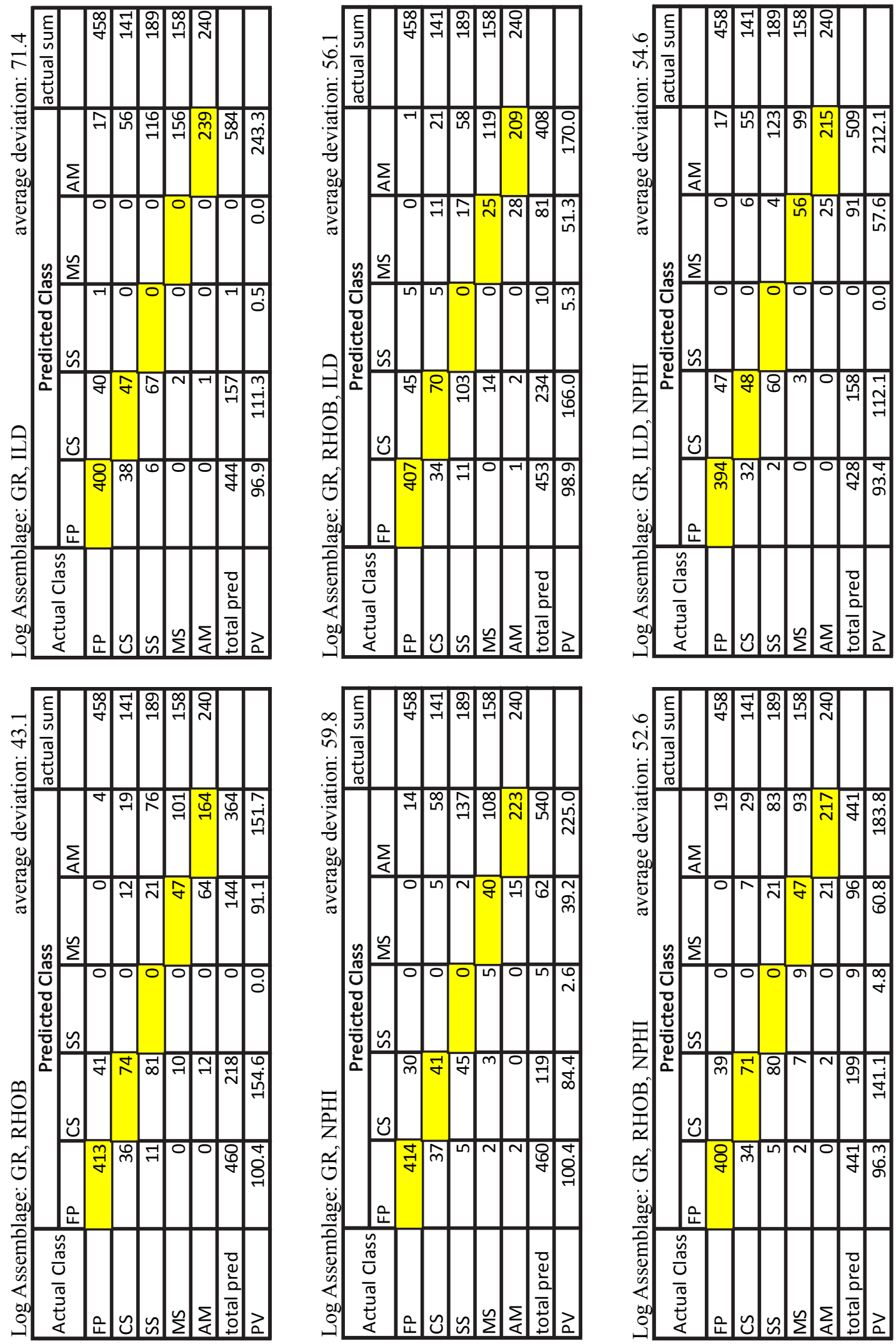


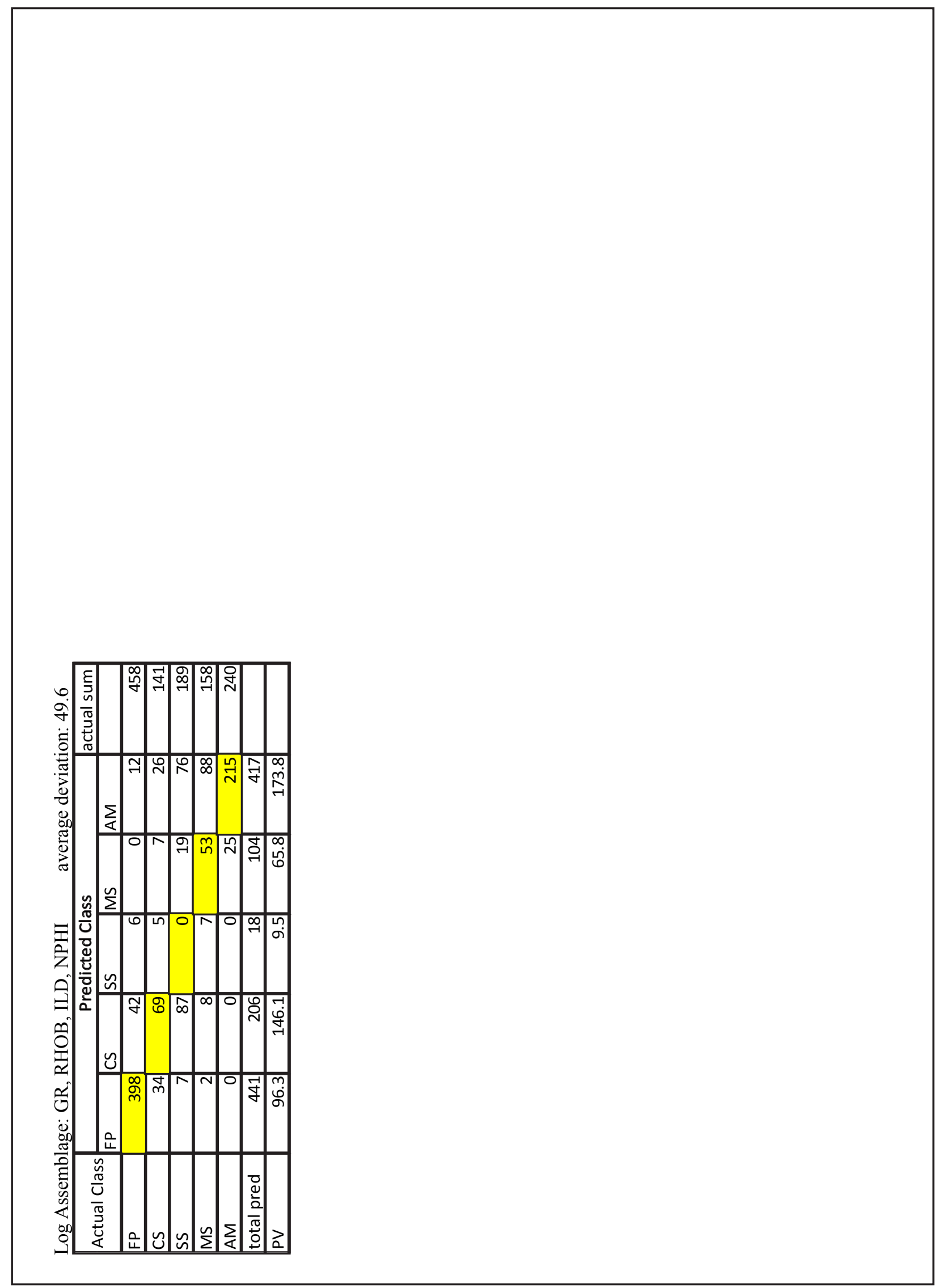




\section{Appendix N}

Confusion Matrices for the Four Class Architectural-Element Realization of the Variably Trained PCP Classifiers

The following tables are the confusion matrices for each variably trained (varying welllog-curve assemblages) PCP classifier that was tested. These provide a visualization of how the testing samples were both correctly and incorrectly predicted. Like in testing of the k-NN classifier, the creation of a simplified four class architectural element realization elicited lowered inter-class confusion through the combination of the previously highly confused and geologically similar multi-story channel body and amalgamated channel body classes. This decrease in interclass confusion is reflected in the lower average deviation values compared to those of the five class architectural element realization found in Appendix M. 

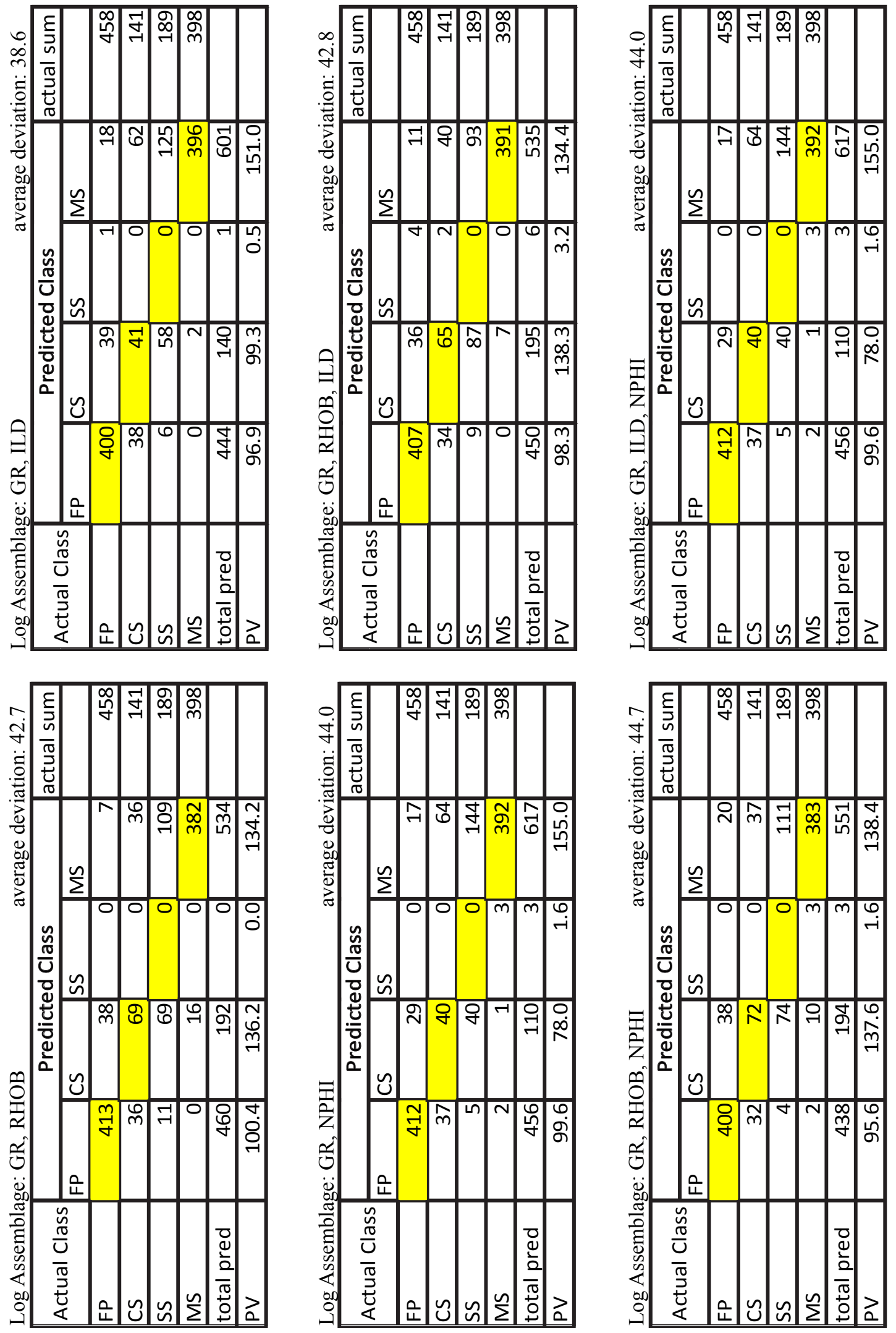


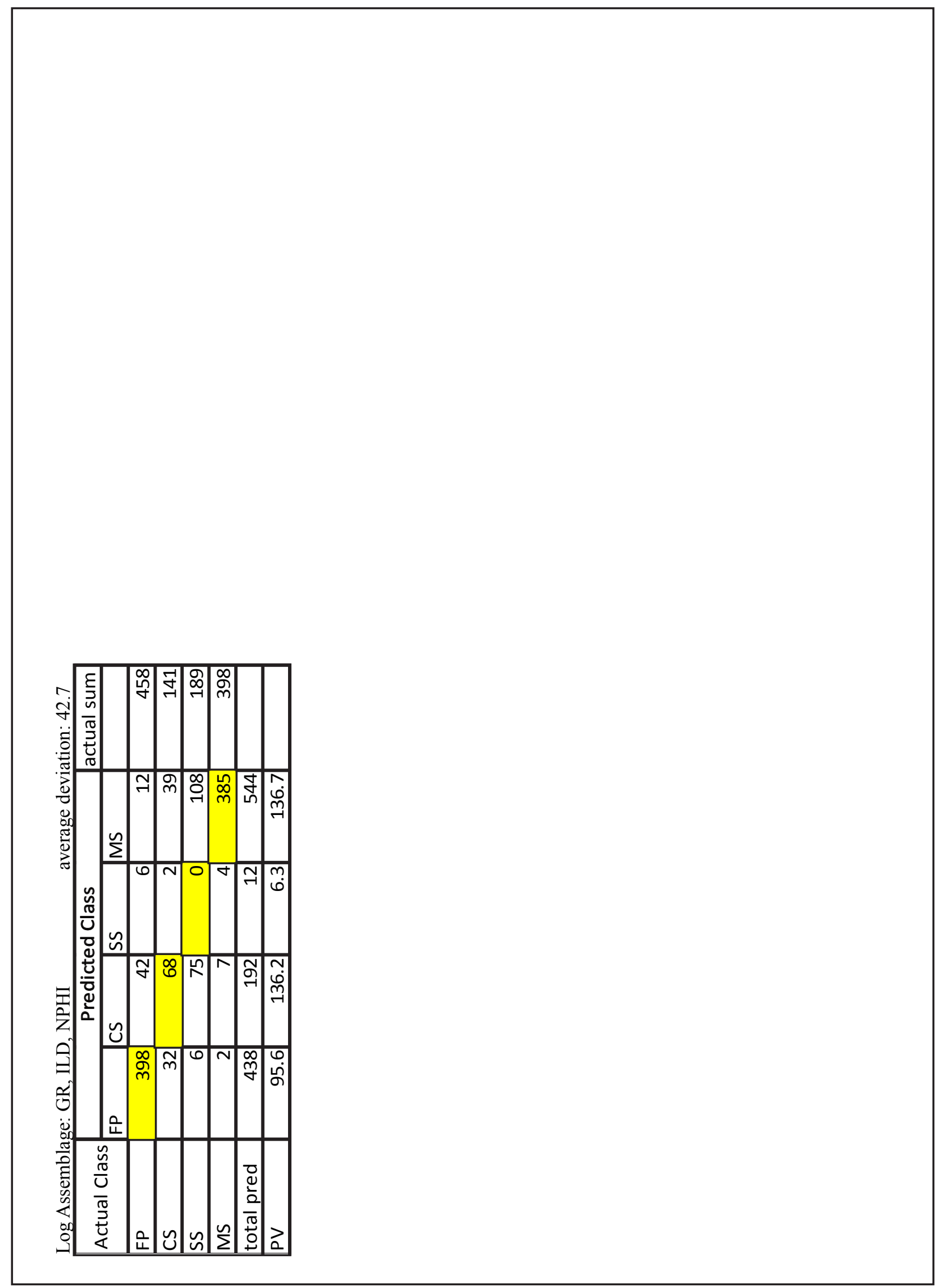




\section{Appendix O}

Accuracy Summary of the Prediction Results for Four Class Architectural-Element Realization for the PCP Classifier

The following tables summarize the success of the variably trained PCP classifiers' in predicting the occurrence of the individual architectural elements "user's accuracy" and the overall accuracy of the classifiers. Highlighted in yellow are two cases which produced identical best overall accuracies and their associated architectural element user's accuracies. 


\begin{tabular}{|l|r|r|r|r|r|}
\hline \multirow{2}{*}{ Well-Log-Curve Assemblage } & \multirow{2}{*}{ Overall Accuracy (\%) } & \multicolumn{5}{|c|}{ Architectural Element User's Accuracy } \\
\cline { 3 - 6 } & & FP & CS & SS & MS \\
\hline GR, RHOB & 72.8 & 0.902 & 0.489 & 0 & 0.960 \\
\hline GR, ILD & 70.6 & 0.873 & 0.291 & 0 & 0.995 \\
\hline GR, NPHI & 71.2 & 0.9 & 0.284 & 0 & 0.985 \\
\hline GR, RHOB, ILD & 72.8 & 0.889 & 0.461 & 0 & 0.982 \\
\hline GR, RHOB, NPHI & 72.1 & 0.873 & 0.511 & 0 & 0.962 \\
\hline GR, ILD, NPHI & 71.2 & 0.9 & 0.284 & 0 & 0.985 \\
\hline GR, RHOB, ILD, NPHI & 71.8 & 0.869 & 0.482 & 0 & 0.967 \\
\hline
\end{tabular}




\section{Appendix P}

Results of Including a First Derivative Transform as a Clustering Variable in the PCP Classifier The following are tables summarizing the accuracies that resulted from the inclusion a first derivative transform of the GR well-log curve as a clustering variable to try to use grain size trends to distinguish between the highly confused crevasse splay and single-story channel body classes. The resulting accuracies are all extremely low except for those of the multi-story channel body which are artificially high due to the high degree of misclassification of the other architectural elements as the multi-story channel body. This confusion can be observed in the confusion matrices which are also included following the accuracy summary tables. The matrices do not show a strong diagonal trend which is a desirable trait of the confusion matrix. Instead, they display scattered high values throughout the matrix cells, indicating that this process lead to results which are mostly noise. Originally the transforms up to a $10 \mathrm{ft}$ (3.05 m) window were to be included in the clustering; however, a software error which indicated that derivatives larger than the $3 \mathrm{ft}(0.91 \mathrm{~m})$ window were too highly correlated with the GR well-log curve and therefore could not be used in clustering. 
$1 \mathrm{ft}(0.30 \mathrm{~m})$ Derivative Window

\begin{tabular}{|l|r|r|r|r|r|}
\hline \multirow{2}{*}{ Well-Log-Curve Assemblage } & \multirow{2}{*}{ Overall Accuracy (\%) } & \multicolumn{4}{|c|}{ Architectural Element User's Accuracy } \\
\cline { 3 - 6 } & & FP & CS & SS & \multicolumn{1}{l|}{ MS } \\
\hline GR, RHOB & 32.5 & 0.063 & 0.376 & 0.037 & 0.744 \\
\hline GR, ILD & 31.4 & 0.052 & 0.348 & 0.048 & 0.729 \\
\hline GR, NPHI & 30.4 & 0.039 & 0.333 & 0.032 & 0.729 \\
\hline GR, RHOB, ILD & 30.7 & 0.046 & 0.333 & 0.032 & 0.729 \\
\hline GR, RHOB, NPHI & 30.9 & 0.044 & 0.319 & 0.042 & 0.739 \\
\hline GR, ILD, NPHI & 32 & 0.037 & 0.340 & 0.063 & 0.761 \\
\hline GR, RHOB, ILD, NPHI & 31.7 & 0.035 & 0.383 & 0.042 & 0.749 \\
\hline
\end{tabular}

$2 \mathrm{ft}(0.61 \mathrm{~m})$ Derivative Window

\begin{tabular}{|l|r|r|r|r|r|}
\hline \multirow{2}{*}{ Well-Log-Curve Assemblage } & \multirow{2}{*}{ Overall Accuracy (\%) } & \multicolumn{4}{|c|}{ Architectural Element User's Accuracy } \\
\cline { 3 - 6 } & & FP & CS & SS & \multicolumn{1}{l|}{ MS } \\
\hline GR, RHOB & 33.4 & 0.055 & 0.418 & 0.032 & 0.769 \\
\hline GR, ILD & 31.9 & 0.039 & 0.383 & 0.016 & 0.761 \\
\hline GR, NPHI & 33.6 & 0.057 & 0.447 & 0.021 & 0.766 \\
\hline GR, RHOB, ILD & 33.9 & 0.063 & 0.426 & 0.016 & 0.779 \\
\hline GR, RHOB, NPHI & 31.8 & 0.037 & 0.362 & 0.011 & 0.771 \\
\hline GR, ILD, NPHI & 34.5 & 0.072 & 0.440 & 0.016 & 0.781 \\
\hline GR, RHOB, ILD, NPHI & 33.4 & 0.066 & 0.426 & 0.021 & 0.759 \\
\hline
\end{tabular}

$3 \mathrm{ft}(0.91 \mathrm{~m})$ Derivative Window

\begin{tabular}{|l|r|r|r|r|r|}
\hline \multirow{2}{*}{ Well-Log-Curve Assemblage } & \multirow{2}{*}{ Overall Accuracy (\%) } & \multicolumn{4}{|c|}{ Architectural Element User's Accuracy } \\
\cline { 5 - 7 } & & FP & CS & SS & MS \\
\hline GR, RHOB & 32.5 & 0.063 & 0.376 & 0.037 & 0.744 \\
\hline GR, ILD & 31.4 & 0.052 & 0.348 & 0.048 & 0.729 \\
\hline GR, NPHI & 30.4 & 0.039 & 0.333 & 0.032 & 0.729 \\
\hline GR, RHOB, ILD & 30.7 & 0.046 & 0.333 & 0.032 & 0.729 \\
\hline GR, RHOB, NPHI & 30.9 & 0.044 & 0.319 & 0.042 & 0.739 \\
\hline GR, ILD, NPHI & 32 & 0.037 & 0.340 & 0.063 & 0.761 \\
\hline GR, RHOB, ILD, NPHI & 31.7 & 0.035 & 0.383 & 0.042 & 0.749 \\
\hline
\end{tabular}




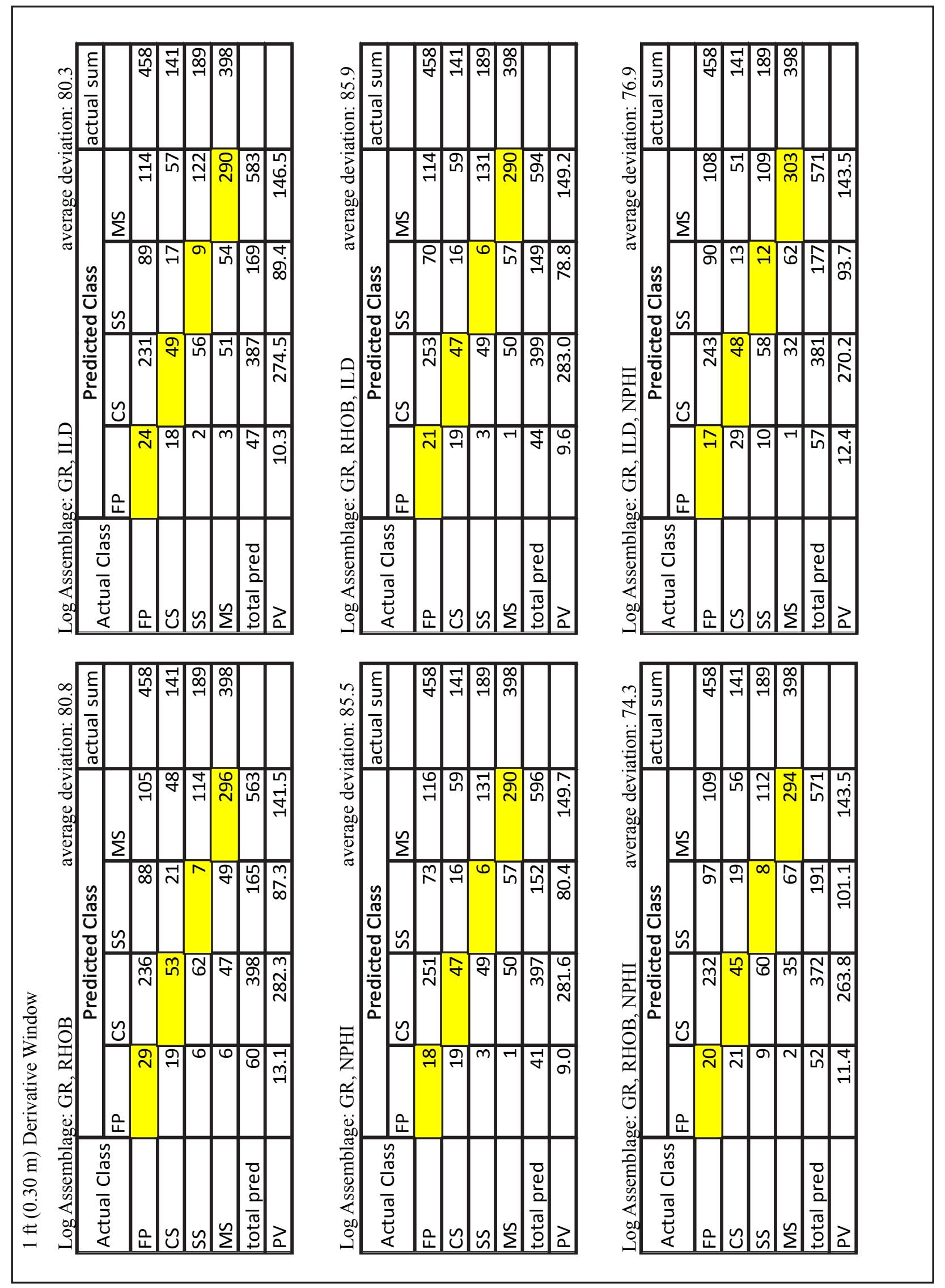




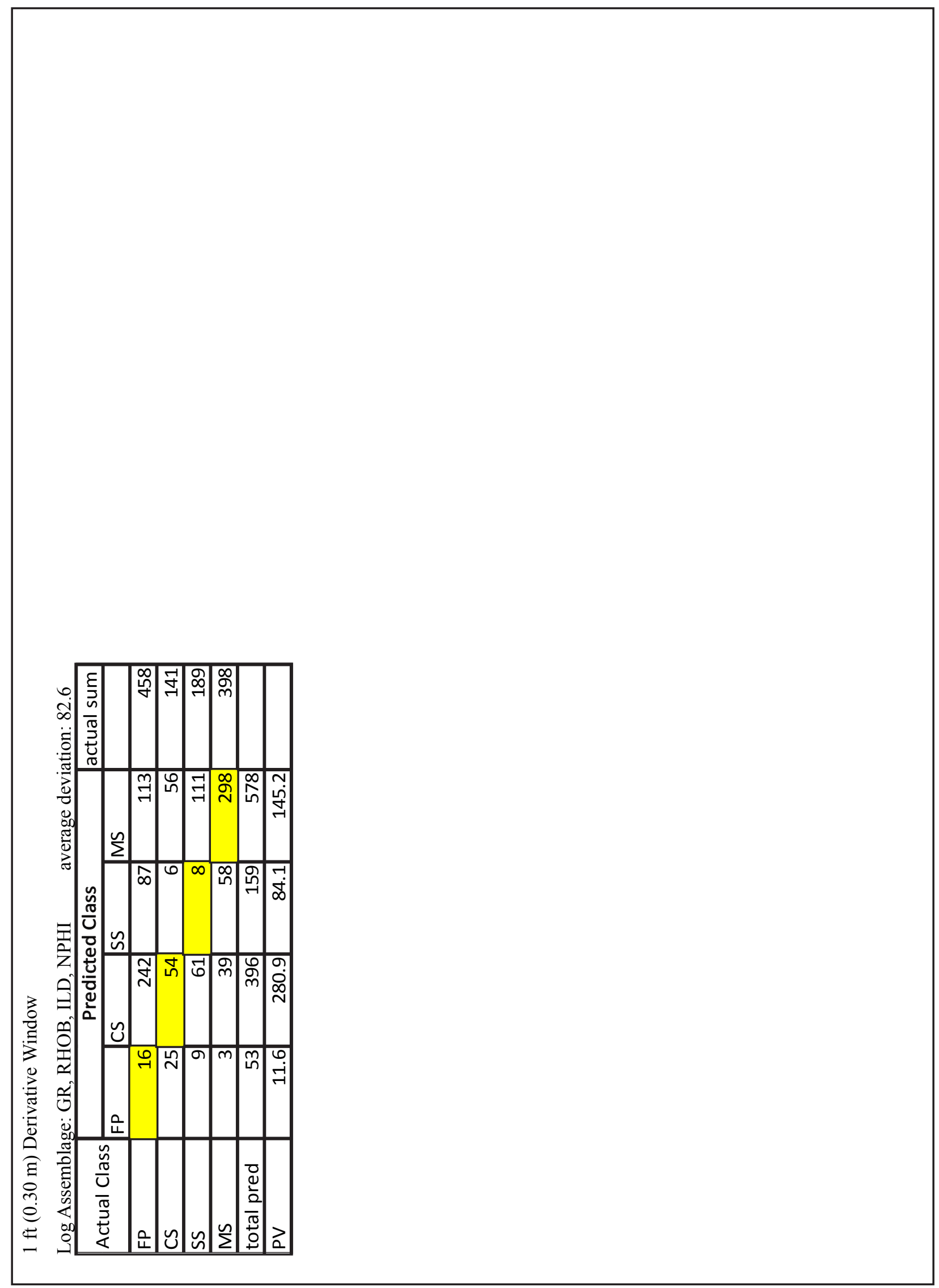


กิ

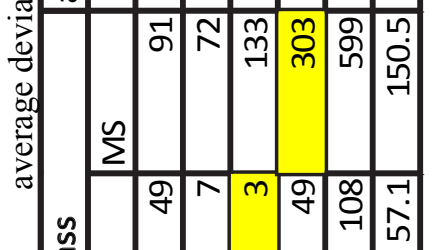

\}

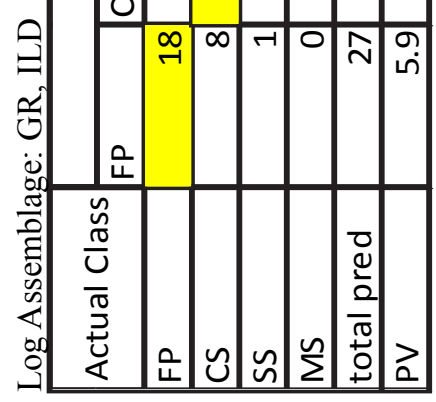

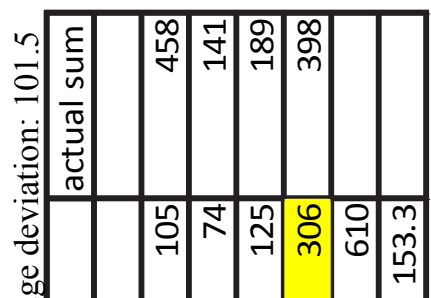

胥

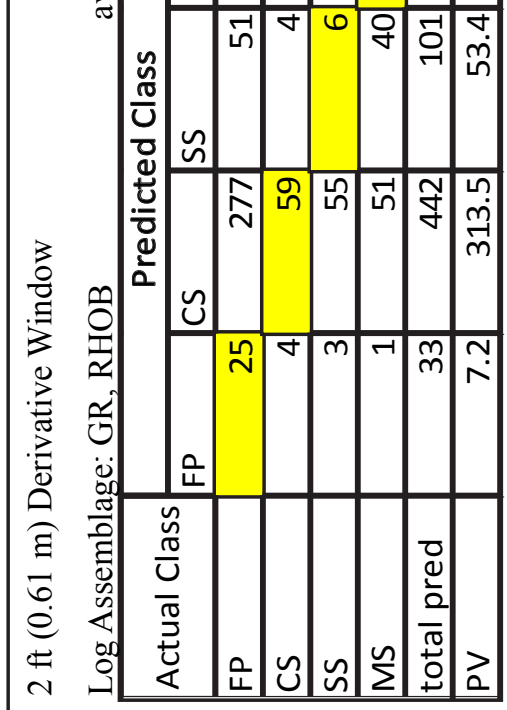

ำ

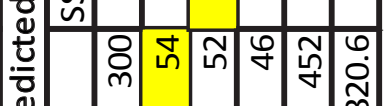

닌

$\exists$

$\Sigma$

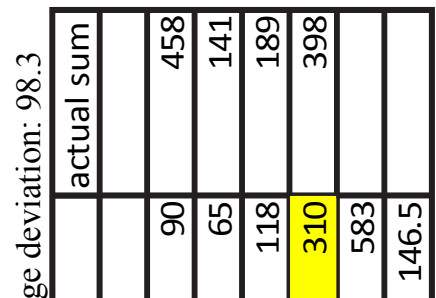

离

जिन 0 वन्वी
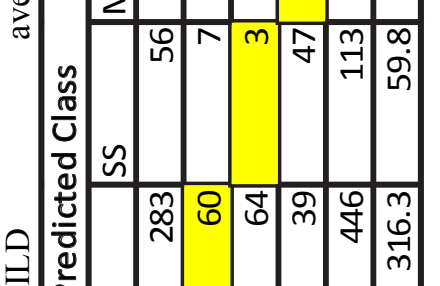

$\exists$

$\frac{n}{2}$

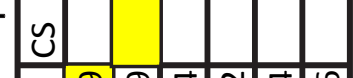

원

范

은
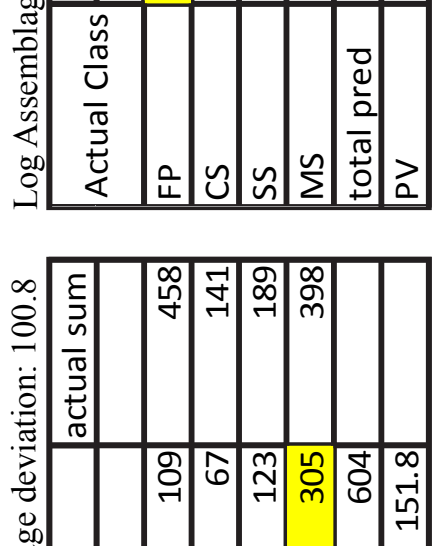

ส

约

tै

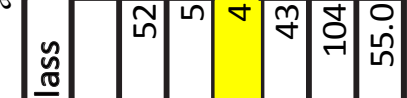

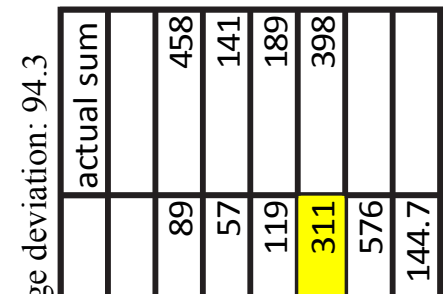

$\frac{\pi}{0}$

空

穵

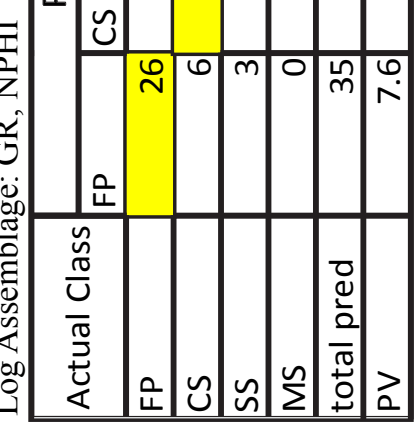

范

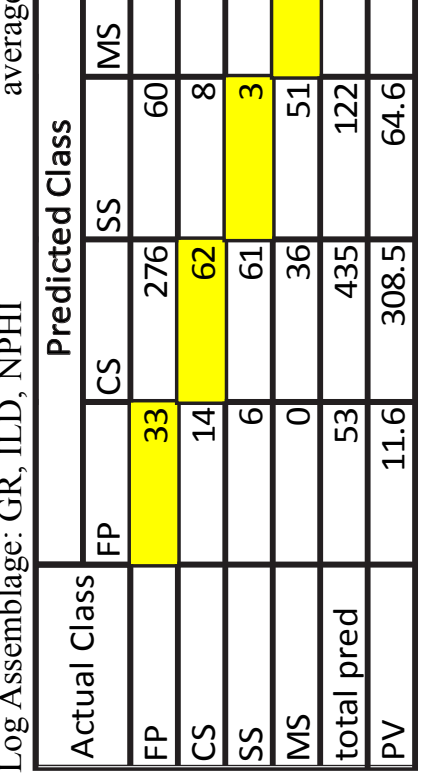

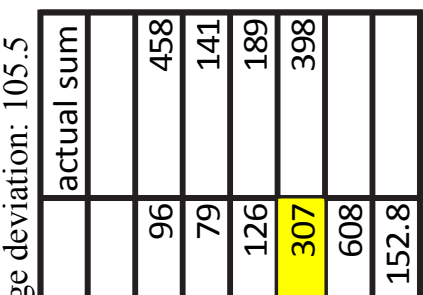

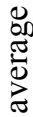

$\Sigma$

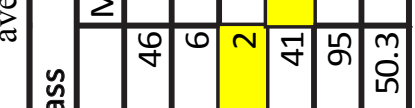

$\frac{\pi}{0}$

品

急言

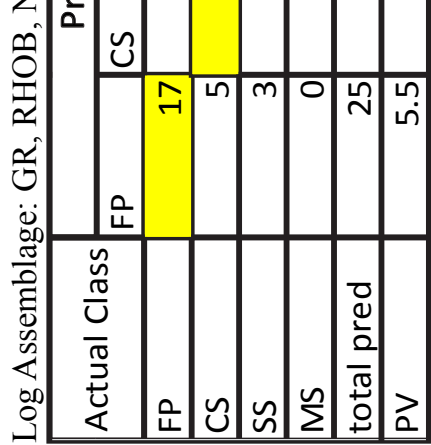




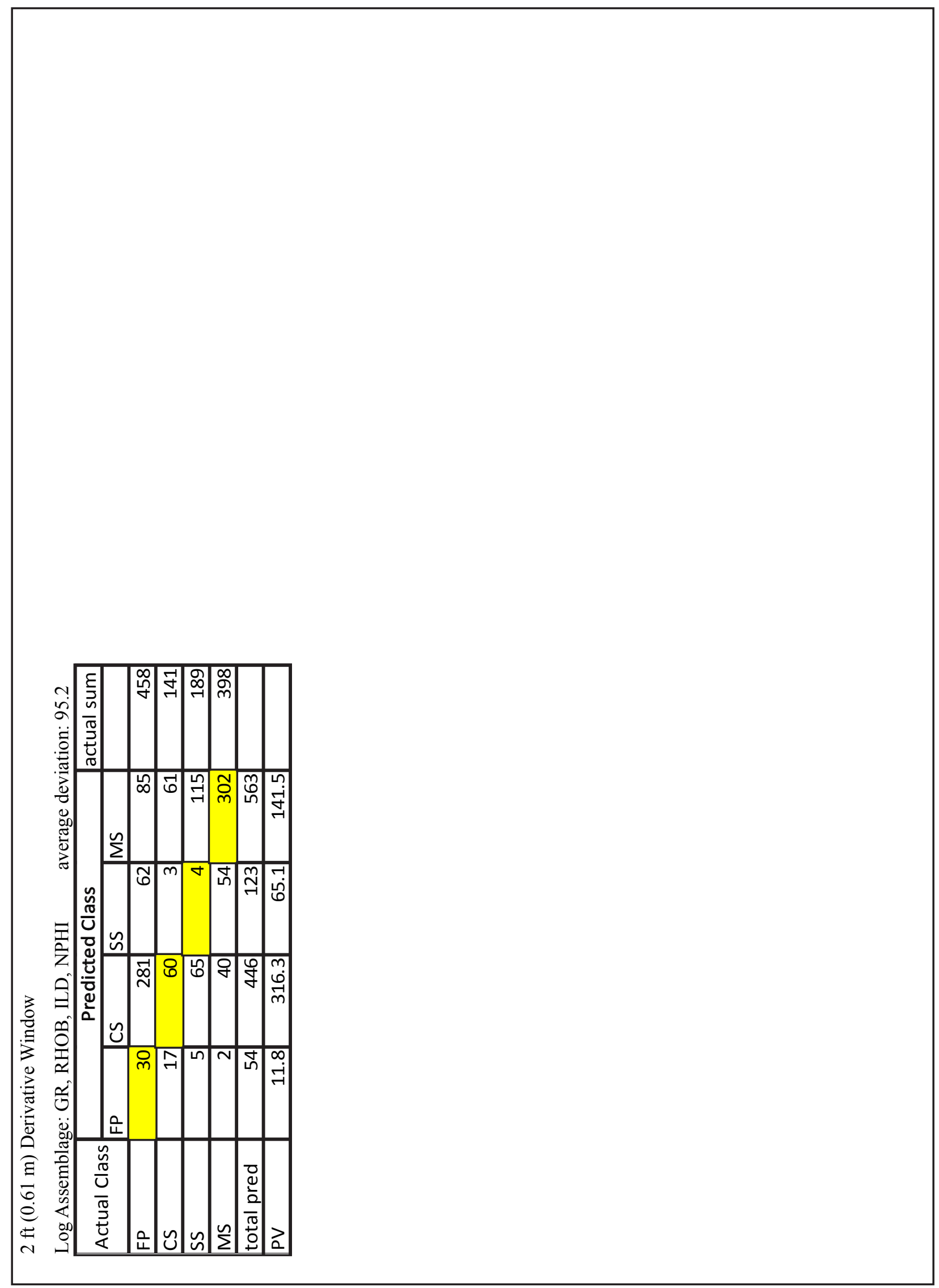



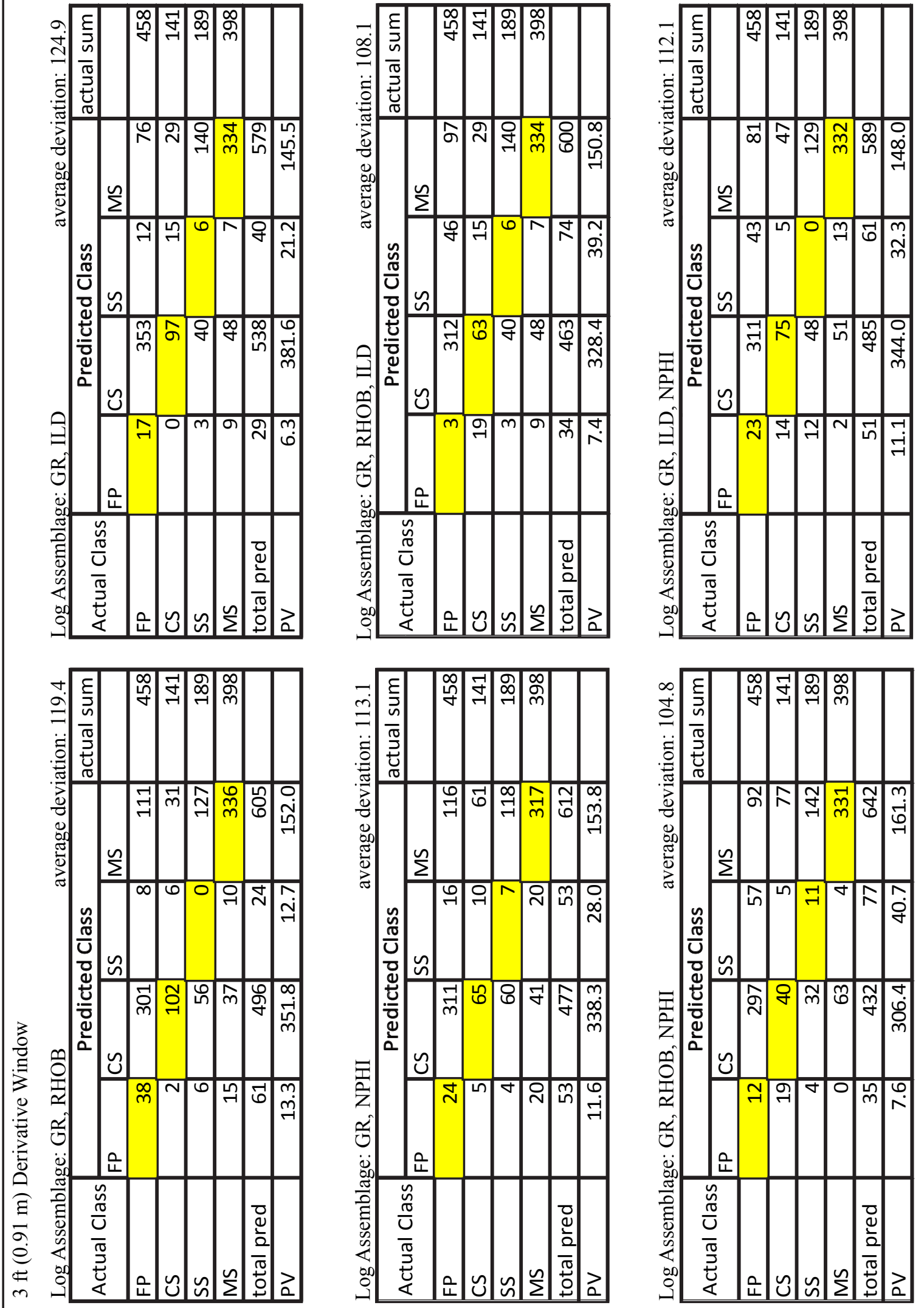


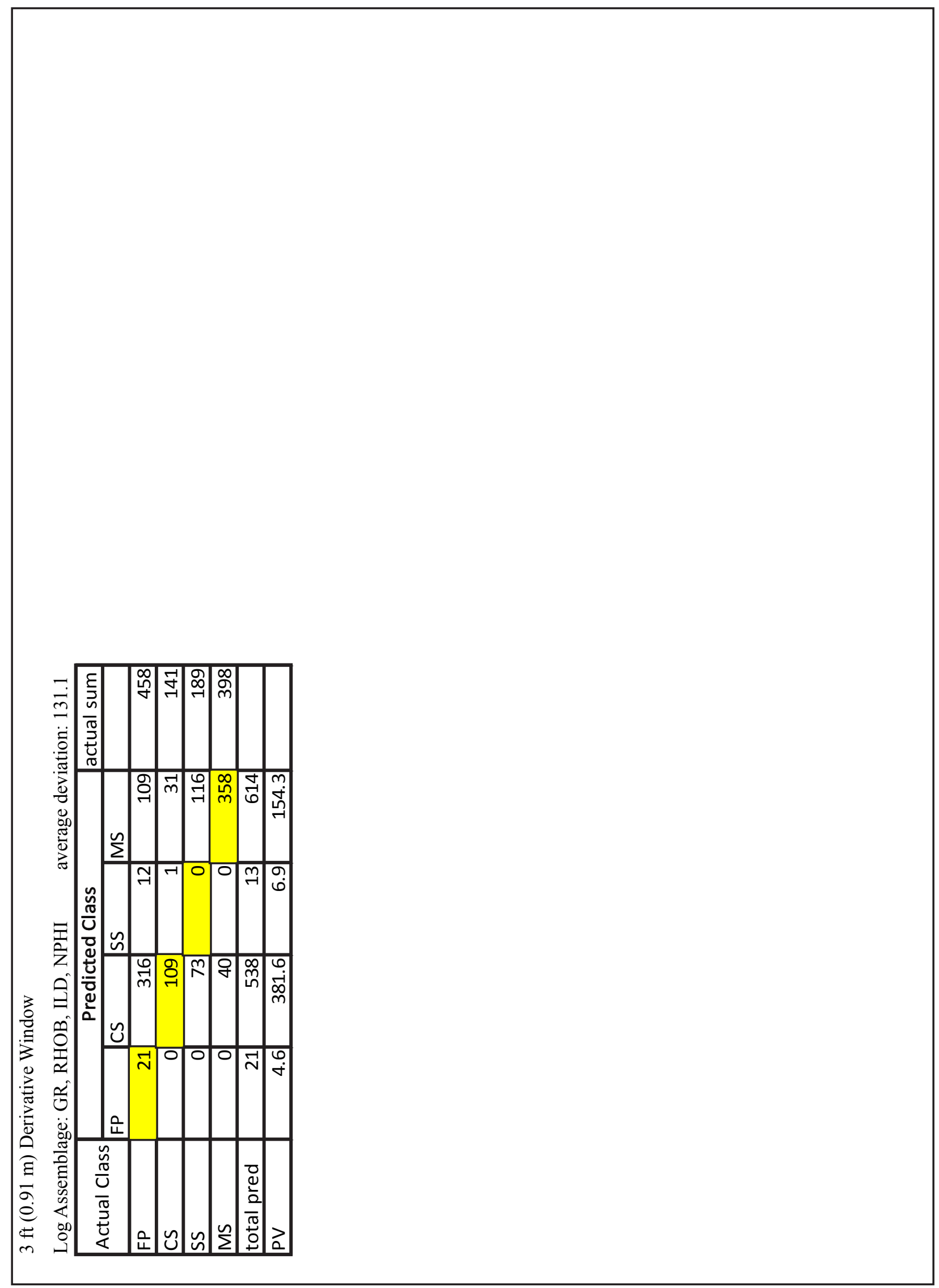




\section{Appendix Q}

\section{User's Accuracy of the Thickness Criteria Approach}

A chart depicting the user's accuracies produced by the application of the thickness criteria approach to the results of the k-NN classifier trained by the well-log-curve assemblage GR, RHOB and $k=20$. It is important to note the vastly improved user's accuracy of the singlestory channel body class as compared to all other classification attempts. 


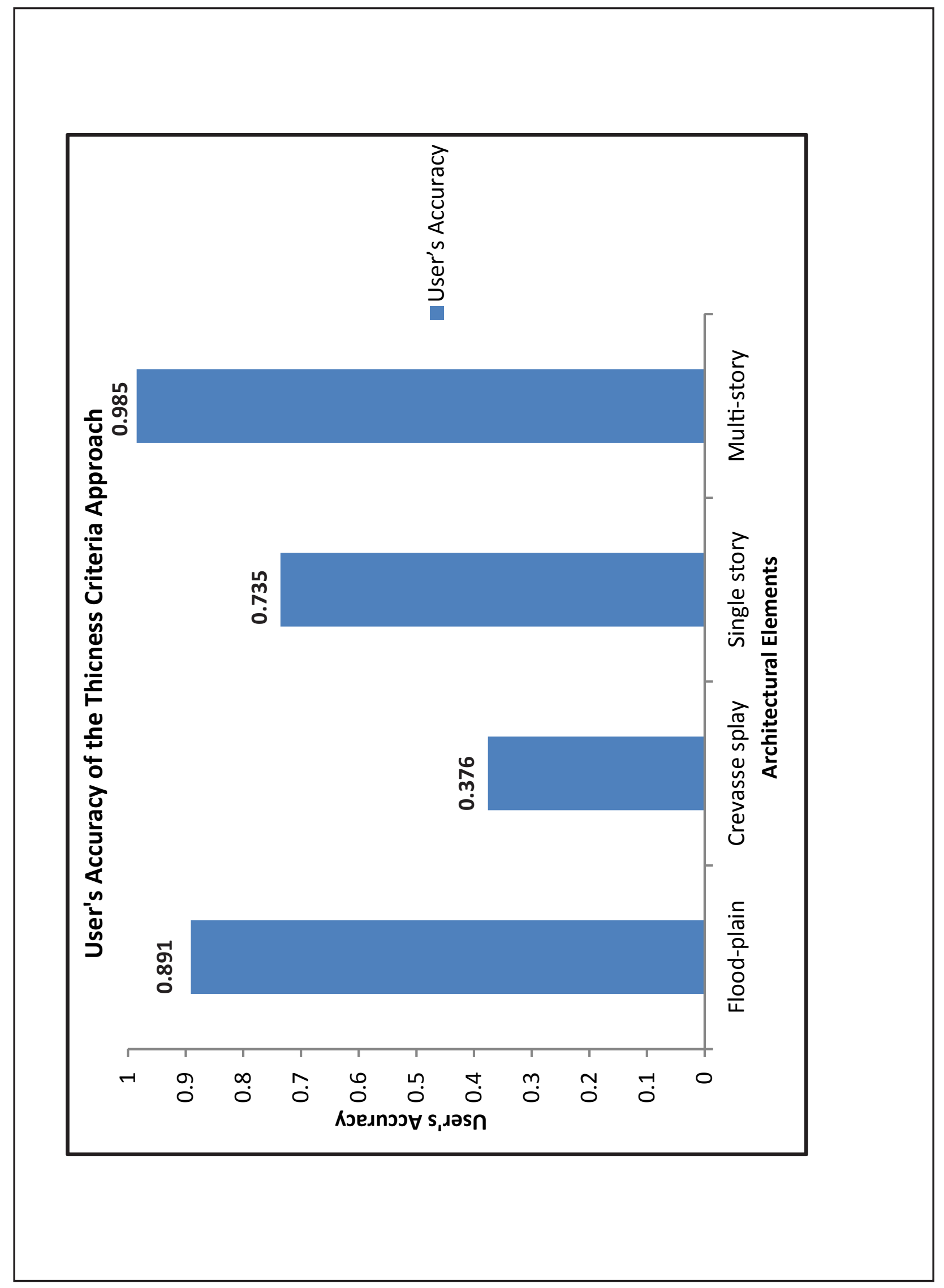




\section{Appendix R}

\section{Equalization of the Training Population}

The following two charts are meant to be a comparison between the outcomes of the k-NN classifier as trained by both an unequalized training population and a training population in which all architectural element classes are represented by the same number of samples $(\mathrm{N}=50)$. Both are trained using the well-log-curve assemblage of GR and RHOB. At smaller k values it was noted that the troubled single-story channel class was predicted better (though still poorly) compared to the larger $\mathrm{k}$ values tested. It was considered that perhaps the poor user's accuracies experienced by the single-story channel class was due to the relatively smaller sampling size of this class compared to the other classes (Drummond, et al., 2010) (Appendix A). A test was conducted in which the numbers of training samples for each architectural element class were equalized to remove any sample size bias. It was found that there was very little improvement in the prediction of the single-story channel architectural element class indicating that training sample size played little to no role in this class' poor prediction. Additionally the user's accuracies of the floodplain and multi-story channel body classes suffered during equalization as a result of their decreased training population sizes. 
Unequalized

\begin{tabular}{|r|r|r|r|r|}
\hline & \multicolumn{4}{|c|}{ Architectural Element User's Accuracy } \\
\hline \hline Neighbors (k) & FP & CS & SS & MS \\
\hline \hline 5 & 0.908 & 0.475 & 0.212 & 0.889 \\
\hline 10 & 0.917 & 0.461 & 0.201 & 0.892 \\
\hline \hline 15 & 0.913 & 0.496 & 0.122 & 0.922 \\
\hline 20 & 0.926 & 0.539 & 0.069 & 0.932 \\
\hline 25 & 0.917 & 0.525 & 0.005 & 0.94 \\
\hline
\end{tabular}

Equalized

\begin{tabular}{|r|r|r|r|r|}
\hline & \multicolumn{4}{|c|}{ Architectural Element User's Accuracy } \\
\hline \hline Neighbors (k) & FP & \multicolumn{1}{|l|}{ CS } & SS & MS \\
\hline 5 & 0.718 & 0.524 & 0.27 & 0.758 \\
\hline 10 & 0.69 & 0.511 & 0.222 & 0.775 \\
\hline \hline 15 & 0.71 & 0.524 & 0.211 & 0.76 \\
\hline 20 & 0.45 & 0.475 & 0.142 & 0.4 \\
\hline 25 & 0.42 & 0.453 & 0.06 & 0.41 \\
\hline
\end{tabular}




\section{Appendix $S$}

\section{Single-Story Channel Body Inter-class Confusion}

The following are two crossplots showing 50 random training samples of the single-story

channel body architectural element class with 50 random training samples of both the crevasse splay class and the multi-story channel body class crossplotted against the well-log curves GR and RHOB. These two crossplots illustrate how similar the single-story channel body architectural element class is to both the crevasse splay and muli-story channel body classes, and helps to explain why the single-story channel body was so often misclassified as these other architectural elements. 
Crevasse Splay and Single-Story Channel Body crossploted against GR vs RHOB

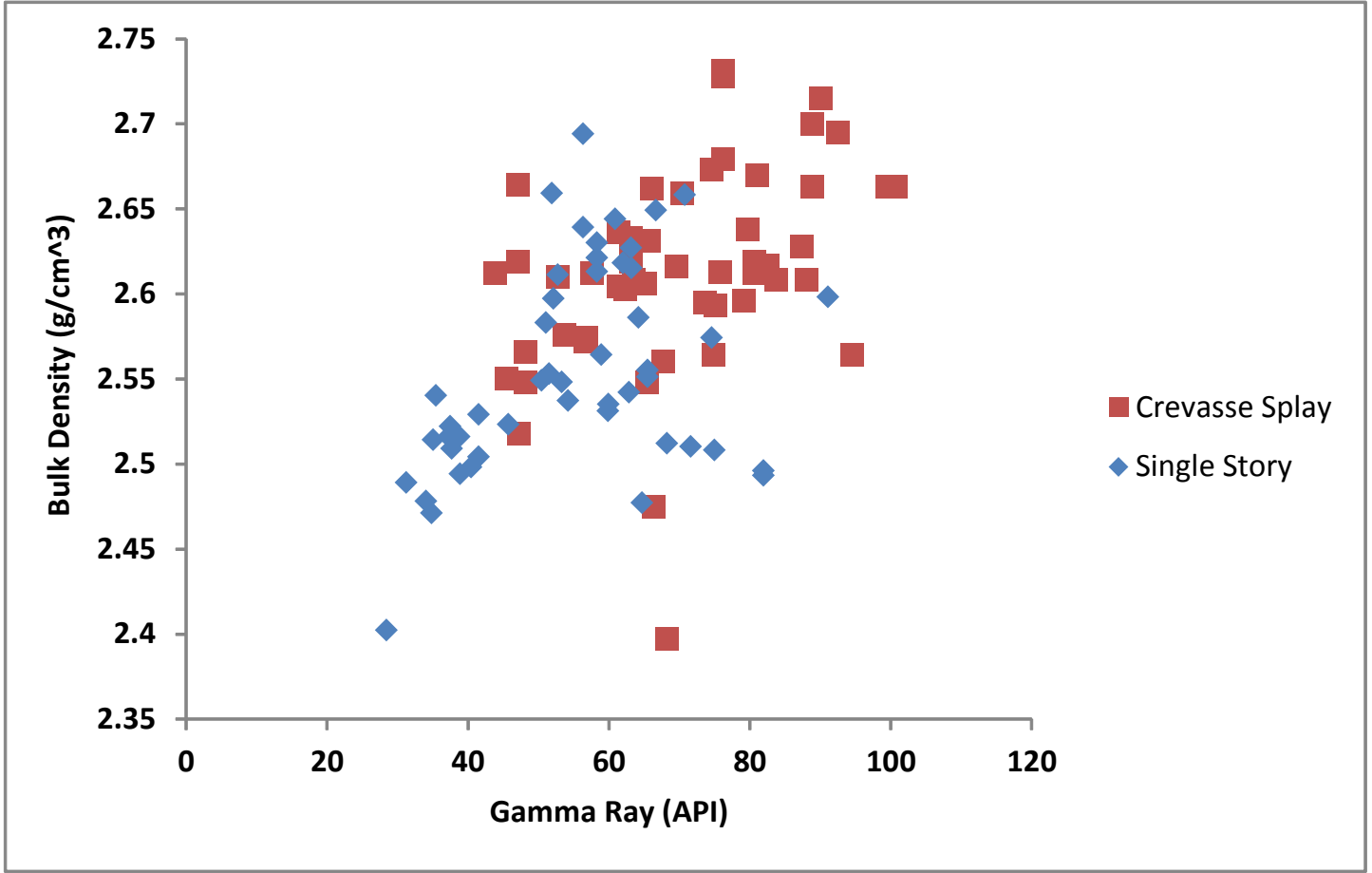

Multi-Story and Single-Story Channel Bodies crossploted against GR vs RHOB

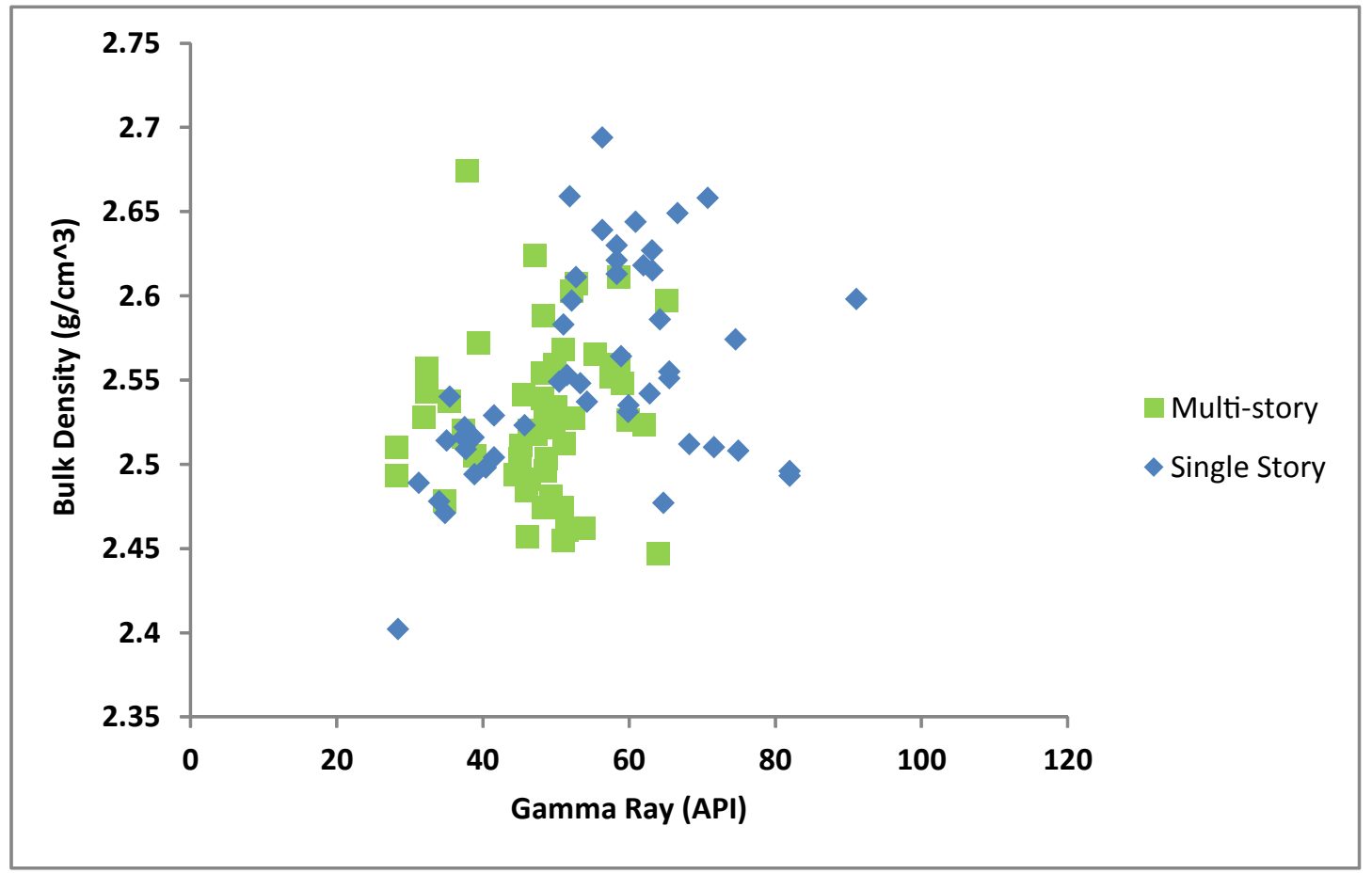

